\title{
diagramas digitais:
}

pensamento e gênese da arquitetura mediada por tecnologias numéricas

\section{Octavio Lacombe}

\author{
orientação: \\ Prof $^{a}$ Dra $^{\mathrm{a}}$ Lucrécia D'Aléssio Ferrara
}


Autorizo a reprodução e divulgação total ou parcial deste trabalho, por qualquer meio convencional ou eletrônico,

para fins de estudo e pesquisa, desde que citada a fonte.

Assinatura:

E-mail: olacombe@terra.com.br

Lacombe, Octavio de Lima Mendes

L142d Diagramas digitais: pensamento e gênese da arquitetura mediada por tecnologias numéricas / Octavio de Lima Mendes Lacombe. - - São Paulo, 2006.

240 p. : il.

Tese (Doutorado - Área de Concentração: Projeto, espaço e cultura) - FAUUSP.

Orientadora: Lucrécia D’Aléssio Ferrara.

1. Arquitetura 2. Tecnologia 3. Projeto de arquitetura I. Título 
para

Beatriz

e nossos pequenos Laura, Diogo, Mario 


\section{AGRADECIMENTOS}

Esta tese não teria sido possível sem a confiança de Lucrecia D'Aléssio Ferrara e a disposição em acompanhar o processo de descobertas e de experimentações proposto desde o início. A intenção não teria se transformado em pesquisa se não fosse sua colaboração constante, sua crítica aguda e sua leitura atenta, a interlocução sábia e a orientação paciente e estimulante. Contar com seu acompanhamento foi um privilégio único que ultrapassa as dimensões desse trabalho. Essas parcas linhas não alcançam o que sua presença de fato representa.

Aos membros da banca do exame de qualificação, Mario Henrique Simão D'Agostino e Giorgio Giorgi Jr., pelas sugestões pertinentes para a continuidade do trabalho.

Ao curso de Arquitetura e Urbanismo da Unimep, especialmente a cordenadora e amiga Marisa Carpintéro que me dispensou enorme apoio e através do programa de capacitação docente possibilitou desobrigar-me de parte de minhas atividades acadêmicas para a dedicação à tese.

Aos professores Agnaldo Farias, Fernanda Fernandes, Laymert Garcia dos Santos e Luis Antonio Jorge que foram interlocutores importantes através dos conhecimentos partilhados nas disciplinas realizadas.

A equipe da biblioteca da FAU, especialmente a Rejane Alves, que sempre dispensou a atenção qualificada que permitiu a consulta necessária à bibliografia disponível.

Aos amigos do curso de Arquitetura e Urbanismo da Unimep Alejandra Devecchi, Carlos Verna, Lúcia Araújo, Mario Braga, Nunão Rother, Nuno Fonseca e Paulo Teixeira, que sempre me apoiaram e com quem pude dialogar sobre questões e preocupações que nos movem.

A Carlos Octavio e Vera Lacombe que me auxiliaram e incentivaram no início dessa trajetória.

Ao Ivan Moretti, companheiro de projetos que compartilha o espaço de trabalho, preocupações e anseios, em quem sempre pude confiar e me apoiou e incentivou.

Ao Maxim Bucaretchi, amigo de todas as horas, que sempre me incentivou a enfrentar os percalços desse caminho e que acompanha essa trajetória desde seus inícios.

Ao Tobias Volpini, pela interlocução provocadora das idéias sempre novas. imagens.

A Marianne Zocal pelo paciente trabalho de levantamento e organização das

A Terry Knight da School of Architecture and Planning do MIT, ao André Favilla do curso de Design da Facamp, ao Wilson Mariana e ao Caracol do curso de Arquitetura e Urbanismo da PUC-Campinas, de quem recebi grande apoio em outros momentos desse percurso.

A Alicia, que nunca me deixou desanimar.

A Bê, Guy, Maná, Karla e Marina; ao Felipe, Gui, Nando, RJ e Zé; aos sobrinhos Bibia, Guigu, Andreco, Luca, Biel, Marina, Calá, Dani, Guga, Bebel, Luisa e Gabrielzinho. Irmãos, cunhados e sobrinhos que me fizeram relaxar nos momentos de encontro, recarregando as baterias para realizar o trabalho.

A Guguta, Maria e Vitório, que de várias maneiras apoiaram a realização desse trabalho, como pais e amigos, mas especialmente como avós carinhosos, cuidando dos pequenos netos para que eu pudesse encontrar a necessária concentração. Sem sua ajuda, seria quase impossível.

A Bia, por sua presença sempre iluminada. Sem sua companhia e seu amor o esforço dedicado a esse trabalho não teria sentido. 
Resumo - palavras chave / Abstract - key words ........ i

Introdução . ............................ 01

DO MECÂNICO AO MAQUÍNICO

ou da imagem-máquina

ao pensamento-máquina

Capítulo 1

DO CORPO AO PENSAMENTO

ou da arquitetura como função

à arquitetura como relação

Capítulo 2

DO PENSAMENTO À LINGUAGEM

ou da arquitetura como estrutura

à arquitetura como sistema

Capítulo 3

A LINGUAGEM DA EXPERIMENTAÇÃO

ou da arquitetura como ordem

à arquitetura como processo e organização

3.1 a invenção da tecnologia digital

ou isto matará aquilo . . . . . . . . . . . . . . 105

3.2 arquitetura do espaço virtual . . . . . . . . . . . . . . . 119

Capítulo $4 \ldots \ldots \ldots \ldots \ldots \ldots \ldots \ldots$. . . . . . . . . . . 131

EXPERIMENTAÇÃO E DESCOBERTA

entre diagramações, desdobramentos e virtualidades

4.1 diagrama da arquitetura maquínica . . . . . . . . . . . . 133

4.2 desdobramentos analógico-digitais . . . . . . . . . . . . 165

4.3 arquitetura no espaço da virtualidade . . . . . . . . . . . 193

Conclusão . . ......................... 211

A arquitetura oscilando entre 0 s e $1 \mathrm{~s}$

Referências bibliográficas . . . . . . . . . . . . . . . . . . . 217

Lista de figuras e crédito das figuras . . . . . . . . . 231 
Esta tese procura compreender o papel da mediação das tecnologias numéricas nos procedimentos (pensamento e gênese) da arquitetura. Parte do pressuposto que o suporte digital, espaço virtual e interativo para a criação do

projeto, é conseqüência da evolução gradual dessas tecnologias no fluxo contínuo das transformações culturais. Entendendo esse fluxo como processo, localiza na segunda metade do século XX a emergência de uma nova racionalidade apoiada nos termos relação, sistema e organização no lugar dos termos modernos função, estrutura e ordem. O pensamento diagramático, a analogia e o dialógico e experimental priom (material/procedimento) caracterizam procedimentos que, assumindo diferentes configurações, possibilitam o reconhecimento de uma arquitetura maquínica.

palavras chave arquitetura, tecnologia, digital, projeto, processo cognitivo.

\begin{abstract}
The thesis intend to understand the mediation of the numerical technologies on architectural procedures (thought and gênesis). It supposes that the digital support as a virtual and interactive space for design is resulting of a gradual evolution of these technologies undergoing through the continuous flux of cultural transformations. It locates at the XX century second half the emergence of a new racionality based on the terms relation, system and organization replacing the modern concepts of function, structure and order. Diagrammatic thought, analogy and the experimental and dialogical priom (material/procedure), enable the recognition of a machinic architeture.
\end{abstract}

key words architecture, technology, digital, design, cognitive process 
Todo homem terá talvez sentido essa espécie de pesar, se não terror, ao ver como o mundo e sua história se mostram enredados num inelutável movimento que se amplia sempre mais e que parece modificar, para fins cada vez mais grosseiros, apenas sus manifestações visíveis. Esse mundo visível é o que é, e nossa ação sobre ele não poderá nunca transformá-lo em outro. Sonhamos então, nostálgicos, com um universo em que o homem, em vez de agir com tanta fúria sobre a aparência visível, se dedicasse a desfazer-se dessa aparência, não somente recusando qualquer ação sobre ela, mas desnudando-se o bastante para descobrir esse lugar secreto, dentro de nós mesmos, a partir do qual seria possível uma aventura humana de todo diferente. Mais precisamente moral, sem dúvida. Mas, afinal, é talvez a essa condição humana, a esse agenciamento inelutável que devemos a nostalgia de uma civilização que procuraria se aventurar fora do que é mensurável.

Jean Genet

Nem a matéria, nem o espaço, nem o tempo, são - há cerca de vinte anos - o que eles sempre foram. É de se esperar que novidades tão grandes transformem toda a técnica das artes, agindo assim, sobre a própria invenção e chegando, talvez, a alterar maravilhosamente a própria noção de arte.

Paul Valéry

Ultimamente, restituído à forma humana, vi chegar um hipopótamo, que me arrebatou. Deixei-me ir, calado, não sei se por medo ou confiança; mas, dentro em pouco, a carreira de tal modo se tornou vertiginosa, que me atrevi a interrogá-lo, e com alguma arte lhe disse que a viagem me parecia sem destino. - Engana-se, replicou o animal, nós vamos á origem dos séculos.

[Brás Cubas] Machado de Assis

Neste ponto só se pode colocar em discussão o sentido da vivência humana no mundo: é preciso saber se tudo aquilo que houve foi projeto ou destino, se o homem construiu sobre os próprios desígnios ou se, pensando fazê-lo, fez algo que já estava dito e decidido. 
introdução

\section{do mecânico ao maquínico}

ou da imagem-máquina ao pensamento-máquina 



\section{PERPLEXIDADE E INDAGAÇÃO}

Não está entre as pretensões dessa investigação fazer apologia das tecnologias digitais nem se render em deslumbramentos por suas realizações. Se por vezes parece estar em defesa dessas tecnologias é porque também se baseia na convicção de que a informatização não encarna a instauração do esvaziamento crítico capaz de aniquilar todos os valores da cultura. Ao contrário, instaurou novos patamares para a produção do conhecimento. Também não há a intenção de valorizar o novo simplesmente pelo sentido de novidade, desqualificando tudo o que lhe seja anterior, em detrimento das tradições e dos conceitos estabelecidos. Pelo contrário, o intento dessas considerações é encontrar as possíveis relações entre a arquitetura como fato cultural e a evolução do conhecimento científico e da capacidade tecnológica que permitiu construir máquinas numéricas como sistemas significantes. Pois se essas máquinas têm o poder transformador que se proclama é preciso compreender e seguir seus passos para que se possa instalar o debate da perspectiva da arquitetura. E assim como a tecnologia digital se insere nos campos da economia, das relações sociais, da saúde e do corpo, da ciência e da arte, também nesses campos se debate, de forma incansável, a busca do estabelecimento de diálogos possíveis.

A postura indagadora e por vezes inquisitiva que se vê nas frentes filosóficas e sociológicas também se encontra na esfera das artes e da arquitetura. Pois se o pensamento que rege a informática se move por instruções, algoritmos, representações do cálculo que engendram ações calculantes e calculadas, o raciocínio da arte conceitual que inventa suas operações não é diferente nem tampouco novo. É o conceito 
que se projeta na arte e isso sim pode parecer estranho à arquitetura, especialmente no caso brasileiro.

A Modernidade Superada de Montaner [2001] serve para ilustrar a passagem de um moderno classicizante para um moderno localizado, com temperos tropicalistas, movimento realizado de forma quase isolada por Lina Bo Bardi e que parece não ter tido um prosseguimento significativo. É difícil imaginar uma virada cibernética com as tonalidades brasileiras, pois não há trabalhos com a visibilidade necessária e suficiente para que possam ser examinados. Se o Brasil teve tantos inovadores, de Lucio Costa a Niemeyer, de Flavio de Carvalho a Artigas, de Millan a Lina, por que esse movimento, como postura e procedimento, não teve continuidade? Pensando na arquitetura no campo da cultura em outras épocas, o que ocorreu para que a disciplina não continuasse em seu caminho de inovação?

Frente à tecnologia informática e digital, a arquitetura brasileira pareceu partir em defesa da própria atividade do arquiteto, de sua identidade como artista criador, sua singularidade intelectual: o desenho. É o desenho que define o arquiteto como artista singular, é através dele que o artista se comunica, é sua linguagem. Não qualquer desenho, mas o desenho sobre o papel, sobre o plano bidimensional, o croquis por onde corre o pensamento. O arquiteto pensa pelo desenho, pensa desenhando. Nunca se viu ninguém questionando, a ponto de negar, a natureza do suporte, ou dos instrumentos de desenho, caneta, nanquim, grafite, ou mais, as questões ideológicas embutidas nas tecnologias do desenho, a geometria, a perspectiva, os cortes e as plantas. Pois se 0 desenho, como diz Mario de Andrade [1965: 69-77], é uma arte intelectual mediadora do espaço e do tempo, um fato aberto, 
uma transitoriedade, nada mais transitório do que as interações elétricas entre 0 s e 1 no espaço dinâmico das simulações e virtualidades do suporte digital.

O temor pela perda da autonomia, do controle de sua singularidade identificadora, levou essa arquitetura a colocar o computador como par excludente e opositor ao desenho. Foi, então disseminada a crença de que não é possível desenhar com o computador. Logo, o computador roubará o lugar do desenho. Assim como Arlindo Machado [1993: 235-251] mostrou que as civilizações indígenas temiam ter seu carom (seu espírito) aprisionado, através da imagem roubada pela câmera fotográfica, o computador seria a máquina de aprisionar a alma da arquitetura, dos arquitetos que seriam roubados pela tecnologia digital.

\section{$[\ldots]$}

Duas questões surgem desse breve panorama, cada uma se multiplica e se desdobra em uma série de outras perguntas que procuram circunscrever o papel do digital para a arquitetura contemporânea. A primeira questão parte do papel dos meios digitais na produção da arquitetura contemporânea: pensamento e gênese. A segunda diz respeito à compreensão desses meios por arquitetos e sua apropriação para o ensino da arquitetura.

Desdobrando a primeira questão aparecem outras indagações. Frente à presença crescente dos meios digitais de processamento de informação de base binária na arquitetura, seria possível tomá-los como caracterizadores da produção contemporânea, na medida em que a produção se faz por simulações e interações, num processo dialógico que faz 
convergir modelos das várias ciências, possibilitando a criação de formas e espaços de grande complexidade? Que transformações esses meios imprimem no processo de criação, na concepção do projeto, na idéia de espaço e forma, na construção da arquitetura como disciplina e como realização? E como se deu a concretização do digital como possibilidade de linguagem (sistema binário que faz a mediação com a experiência e o conhecimento)? O digital representa de fato uma ruptura com a arquitetura do passado? Esse suporte provoca de fato um impacto? Em que medida? Há antecedentes dessa tecnologia? Quais seriam? Quais suas raízes?

A segunda questão se desdobra nas indagações sobre a existência de uma resistência por parte dos arquitetos com relação ao digital. Porque a limitação desses meios à otimização da produção de plantas, cortes e outros documentos baseados no desenho como código expressivo? Porque recusar sua utilização como instrumento para pensar a arquitetura? Porque se considera impossível utilizá-lo para projetar, para criar? Porque os recursos digitais estão associados à idéia de dano, de perda da capacidade criadora? Porque não explorar suas possibilidades no ensino da disciplina, nos processos de criação? A questão se redobra sobre a primeira, pois suas explicações seriam prováveis indicações para outras possibilidades de compreensão e utilização dos meios digitais.

\section{O MOMENTO DE EXPLOSÃO}

Procurando dar um sentido crítico ao impacto das tecnologias da informação digital na cultura, Laymert Garcia dos Santos [2003: 82] indaga sobre a dimensão e o alcance de um 
possível rompimento com o passado promovido pela

tecnociência. Caso se trate de uma ruptura tão drástica a ponto de anular o quadro referencial a partir do qual se organiza a experiência, com que conceitos pensá-la em sua especificidade? Antes de prosseguir com as indagações em busca de respostas para pensar a condição atual, parece ser fundamental esclarecer a postura frente às tecnologias de informação digital. Como vêm chamando a atenção alguns pesquisadores, as tecnologias informáticas, numéricas ou digitais são com grande freqüência chamadas de novas e tem sido invariavelmente associadas à idéia de impacto. Como diz Irene Machado [2005] defensores e detratores dispensam tratamento comum quando se trata dessas tecnologias.

Pierre Lévy [1999: 21-30] diz que o uso corrente da idéia de impacto das novas tecnologias parte de uma comparação com a imagem de um projétil, que repentinamente encontra um alvo e causa efeitos imprevistos. Como se as tecnologias não fossem imaginadas, fabricadas e reinterpretadas pelo uso, ao longo do tempo. Como se fosse uma tecnologia sem história que teria autonomia, estaria separada da sociedade e da cultura? Talvez, diz Lévy, um agravante na dificuldade de análise e compreensão das tecnologias da informação resida na ausência radical de estabilidade, promovida por alterações e inovações constantes.

Duas questões merecem atenção nesse tratamento dado às tecnologias digitais. Primeiro a idéia de novo, de que essas tecnologias, apesar de consolidadas no tempo, ainda são consideradas novas. Sua estrutura de funcionamento permanece a mesma desde que foram construídos os primeiros computadores e suas bases conceituais e matemáticas tem uma longa história que remete a Arte Combinatória de Leibniz. 
As tecnologias numéricas são tão antigas quanto ou mais que as tecnologias para formar imagens, o digital tão antigo quanto a gênese das escritas. As primeiras máquinas que traduziram informações em dígitos através do código binário foram construídas por volta dos anos 40, mesma época em que foram realizadas as primeiras experiências com os transmissores de imagem televisiva. Os computadores pessoais iniciaram sua popularização na década de 70 , mesmo período da disseminação do vídeo cassete e da câmera portátil de vídeo. Nem por isso se qualifica a televisão ou o vídeo como novas tecnologias. Apesar do uso corrente dos computadores nas esferas do trabalho e da educação, mesmo com a multiplicação de ferramentas digitais como câmeras fotográficas, aparelhos de áudio, conexões em rede e uma infinidade de dispositivos de uso cada vez mais cotidiano, essa impressão do novo talvez advenha da convergência dos meios promovida pelo digital que imprime sempre novas configurações para outras tecnologias.

Segundo, a noção de impacto. É preciso concordar com Irene Machado [2005] quando defende a necessidade de rever os conceitos e ponderar os sentidos do campo semântico do emprego tão genérico do termo. Ela explica que o significado de impacto está vinculado a noção de força. Passando para o campo bélico, se associa ao choque de um projétil contra um corpo ou superfície. Assim, a ação do impacto procede do exterior para o interior, sem mediação, ação que causa reação imediata. O impacto da tecnologia, aplicado a esferas tão heterogêneas como o ambiente (impacto ambiental no sentido de dano) e a saúde (próteses no sentido de impacto positivo), esvazia de sentido o objeto a que se refere. É preciso questionar, portanto, como a ação de algo exterior, lançado como um projétil sobre um alvo, pode ter uma duração tão prolongada? Será que as tecnologias de informação e a 
digitalização dos meios de representação ainda são capazes de causar impacto depois de três décadas de presença? Quanto tempo pode durar um impacto?

Outra abordagem pode ser encontrada nos estudos do semioticista russo luri Lotman, conforme apresentada por Irene Machado [2003; 2005]. Lotman diz que os produtos das transformações dinâmicas dos processos culturais resultam de momentos explosivos instalados no interior de processos de desenvolvimento gradual. Seu conceito de explosão recorre à metáfora do big bang, marco da expansão do universo, momento explosivo, atemporal e plurissecular, estalo que vem do passado e contém todas as possibilidades de futuro, transformando inexoravelmente a rota dos acontecimentos.

"O momento de explosão interrompe a cadeia das causas e dos efeitos e projeta na superfície um espaço de eventos igualmente prováveis dos quais é impossível por princípio dizer qual se realizará. O momento de explosão se coloca na intersecção do passado com o futuro numa dimensão quase atemporal" [LOTMAN apud MACHADO, 2005: s/n]

Explosão como expansão, processo gradual, relacional e dialógico com os elos do sistema em que se insere. É possível considerar a cultura contemporânea como um momento explosivo uma vez que as tecnologias digitais criam relações dialógicas com o passado e apontam possibilidades de um futuro aberto e indeterminado. A explosão como desenvolvimento acelerado de sistemas abriga radicais transformações no interior da cultura de forma encadeada promovendo a expansão dos sistemas e não sua destruição. Pensando nas tecnologias digitais, a escrita seria o componente mais explosivo do sistema. Se a cultura letrada explodiu com a oralidade, em tempos de informação eletrônica a escrita se 
expandiu em sistemas notacionais e em sistemas numéricos, caso da digitalização [MACHADO, 2005]. Assim ocorre com a arquitetura que, imersa na digitalização, faz explodir a analógica da percepção pela numerização do corpo, pela informatização da experiência geométrica do espaço, agora transformados em linguagens.

"A humanidade tem vivido entre os séculos XVIII e XX um processo que pode ser descrito como realização de uma metáfora: os processos sócio-culturais se encontram sob influência da imagem da explosão não como conceito filosófico, senão em sua vulgar correlação com a explosão da pólvora, da dinamite ou do núcleo atômico. A explosão como fenômeno físico, transferível só metaforicamente a outros processos, tem sido identificada pelo homem contemporâneo com idéias de devastação e se tornou símbolo da destruição. Contudo, se na base de nossas representações de hoje estivesse a associação com as épocas dos grandes descobrimentos, como o Renascimento, ou em geral com a arte, então o conceito de explosão evocaria em nós fenômenos como o nascimento de uma nova criatura viva ou qualquer outra transformação criativa da estrutura da vida". [LOTMAN apud MACHADO, 2005]

\section{OS CAMPOS POSSÍVEIS DA INFORMAÇÃO DIGITAL}

Nesses momentos de explosão, segundo o conceito de Lotman, a humanidade se reinventa. Lévy considera que o momento atual seja uma dessas épocas limítrofes em que toda a ordem de representações e saberes oscila e se transforma dando lugar a outros modos de desenvolvimento e conhecimento ainda não estabilizados [LÉVY, 1993: 17]. Assim, numa abordagem econômica, é possível compreender os modos de desenvolvimento como arranjos tecnológicos em que 
a força de trabalho atua sobre a matéria no processo de produção. No modo industrial, o aumento da produção se baseia na introdução de fontes de energia e na qualidade de seu uso. No modo informacional, a produtividade se baseia na qualidade do conhecimento. Tecnologia é exatamente isso, uma vez que tecnologia é o uso de conhecimentos científicos para especificar maneiras de fazer de um modo reprodutível. $\mathrm{O}$ que é específico do modo informacional de desenvolvimento é que o conhecimento intervém sobre o conhecimento em si para gerar maior produtividade; o conhecimento que gera conhecimentos novos é a fonte da produção e da produtividade. O modo informacional é orientado para o desenvolvimento da tecnologia, isto é, para o acumulo de conhecimento.

[CASTELLS, 1989: 2-12]

Desse modo, ainda segundo Castells, se instaura outro paradigma tecnológico caracterizado por dois aspectos fundamentais: primeiro as tecnologias estão direcionadas para o processamento de informação, tanto a matéria prima quanto o produto são informação em si; segundo, os principais efeitos das inovações tecnológicas recaem sobre o processo e não sobre o produto. Isso também ocorreu com as outras duas revoluções industriais, que se organizaram em torno da máquina a vapor e da eletricidade. O foco era a energia que transformou os processos de produção e gerou novos processos de comunicação.

Trata-se de uma economia do desempenho e não da produção. As tecnologias digitais informáticas concebem conhecimento e pensamento como acumulação e troca, comunicação. Pensar vai além de comunicar e pressupõe em relação à informação uma inteligência capaz de distinguir os falsos problemas. As máquinas informáticas passam a parecer 
mais importantes que a língua e o indivíduo. Assim, Freud e Saussure cedem lugar a Turing - logicismo filogenético com concepção de máquina e a Von Neumann - primeiro computador numérico, o que confere à informação a impressão de ser mais do que de fato é, um tipo de poder, uma forma de criar riqueza e miséria. Se as tecnologias podem determinar os campos de possíveis da subjetividade, o importante é saber como e onde o digital se insere permitindo criar possibilidades [RAJCHMAN, 2000: 400-406].

Durante décadas, uma série de inovações científicas e tecnológicas convergiram para determinar esse outro paradigma tecnológico: o transistor (1947), o circuito integrado (1957), o microprocessador (1971), as técnicas de divisão de genes (1973) e o microcomputador (1975). A disseminação dos computadores, a revolução no processamento de informações, a variedade de aplicações em softwares e hardwares, a difusão desses avanços através das telecomunicações, que permitiram conexões e sistemas de rede, a aplicação dessas tecnologias em sistemas CAD e CAM transformaram a produção e permitiram o desenvolvimento de novos materiais. Tudo isso possibilitou perceber a vida viva como informação em si, uma vez que a biotecnologia aproveitou a capacidade de análise e armazenamento de informações para decodificar e reprogramar o código genético [CASTELLS, 1989:12].

A única 'coisa' que conta na nova ordem é o que pode ser capturado da realidade e traduzido numa nova configuração, ou seja informação [SANTOS, 2003: 84]. Nessa condição estão construídas a cultura, as ciências e as tecnologias, por uma operação comum de tradução do mundo em termos de codificação, isto é, a busca de uma linguagem comum na qual toda a resistência ao controle instrumental desaparece e toda a heterogeneidade possa ser submetida à 
desmontagem, à remontagem, ao investimento e à troca. [HARAWAY, 2000: 70]. Isto remete à arte combinatória de Leibniz, que esboçou os pressupostos da linguagem simbólica contemporânea, um conjunto de símbolos que, segundo Michael Heims [1991: 67-69], formava uma linguagem elétrica e que estaria na gênese de toda a linguagem de computação. Linguagem binária universal que poderia reduzir todos os problemas da humanidade aos mesmos símbolos, foi a base para o desenvolvimento da lógica dos conjuntos de Boole, aplicada por Shannon à teoria da informação e utilizada por Von Neumann para construir o primeiro computador.

"A informação torna-se crucial a partir do momento em que a dimensão virtual da realidade começa a ser mais importante do ponto de vista econômico e tecnocientífico do que a sua dimensão atual. (. . .) Trata-se de privilegiar o virtual e de preparar o futuro para que ele já chegue apropriado, trata-se de um saque no futuro e do futuro. $E$ aqui se encontra uma questão perturbadora. A modernidade instaurara, como princípio supremo, a ruptura com os valores do passado e a consagração do novo e do inédito. Nesse sentido, o mundo moderno significou a desvalorização dos outros tempos, sacrificando a história em benefício do presente. (. . .) Mas a aceleração tecnológica e econômica contemporânea é tal que até mesmo o atual acaba sendo ultrapassado: em sua perspectiva, tudo o que é, já era. Assim, a aceleração tecnológica e econômica desloca o interesse pelo atual e pelo presente decretando, com tal deslocamento, o fim da modernidade. A atenção concentra-se não no que é, mas no vir-a-ser. O olhar se volta para o futuro; melhor dizendo: para a antecipação do futuro". [SANTOS, 2003: 88] 
Se, como dizem Deleuze e Guattari [1992: 237-240], a arte começa de fato com um animal que recorta um território e faz uma casa, colocando desse modo a arquitetura como primeira das artes, talvez se possa compreender porque surge uma polêmica a cada tentativa de estabelecer a peculiaridade da arquitetura no campo da cultura, pensando-a em um contexto amplo, como resultado do cruzamento de discursos e visões de mundo, em sua relação especular com outros campos do conhecimento [GUERRA, 1993]. Como se trata da primeira das artes, pode ser que se esconda em seus meandros um certo sentimento de autonomia, que outorga o direito de não dar satisfação a nada nem ninguém, estando acima de todas as coisas.

Não seria diferente ao se colocar a arquitetura em relação às tecnologias da informação. Se de fato a informação é a chave da economia de hoje, é preciso levar em conta que a informação é a única substância que cresce com o uso, em vez de decrescer, como acontece com os recursos naturais. Uma definição atual da economia da era da informação seria 'economia de abundância' [KERCKHOVE, 1997: 95]. Otília Arantes lembra a identificação congênita da arquitetura do Movimento Moderno com a abstração capitalista. Citando Tafuri, realça que a arquitetura ao se ligar à realidade produtiva aceita a sua mercantilização, integrando eficazmente o design a todos os níveis de intervenção, em um projeto destinado a reorganizar a distribuição e o consumo do capital [TAFURI apud ARANTES, 1993: 56].

Ainda segundo Arantes, cabe perguntar se a arquitetura a partir dos anos 70 não é conseqüência do movimento moderno que tendo exaurido a energia utópica, se fez 
sobreviver como forma à função extinta [ARANTES, 1993: 84]. Assim também entende Peter Eisenman [1976] ao defender um pós-funcionalismo no lugar do pós-modernismo. Para ele, a estandartização e os processos tecnológicos são usados para criar a possibilidade de um excesso que hoje reside no capital. Sugerir a possibilidade de um excesso no objeto, na arquitetura e no espaço, que requeira uma mudança radical nos modos de produção existentes de fabricação e consumo, se converte em um ato político [EISENMAN, 1997: 35].

Desde o Renascimento, a arquitetura sempre olhou para as ciências procurando formalizar conceitos através da linguagem da forma e do espaço. Talvez a dificuldade em encarar o material numérico esteja em sua extrema complexidade, que já apresenta determinadas interpretações do mundo, formalizadas pela linguagem da racionalidade do cálculo. Mas não parece possível, como aponta Couchot [2003: 287-288], que o arquiteto deixe de fazer uma reflexão sobre essa convergência das ciências na esfera da linguagem numérica, da digitalização da informação. Essa reflexão necessária e já tardia requer uma tomada de posição estética e ética, de uma abertura para um universo a descobrir e transformar e nem tanto uma especialização tecnológica ou científica.

"Há muito tempo a matemática tornou-se independente de toda finalidade estranha ao conceito de si mesma que ela formou pelo desenvolvimento puro de sua técnica, e pela consciência que adquiriu do próprio valor desse desenvolvimento. (...) Uma arte das idéias, uma arte da ordem das idéias, ou da pluralidade das idéias, seria uma concepção de todo vã? Acho lícito pensar que toda arquitetura não é concreta, que toda musica não é sonora. Existe um certo sentimento das idéias, de suas analogias, que me parece poder atuar e ser cultivado 
como o sentimento do som ou da cor." [VALÉRY, 1998:

O problema colocado pelo numérico se situa entre a tradição e a inovação de uma sociedade que procura manter seus sistemas de regulação e a necessidade de adequação à revolução tecnológica irreversível que impõe a reorganização desses mesmos sistemas. Uma sociedade dividida entre o tempo da história que demora e o tempo real e febril, das trocas dialógicas. Uma sociedade despedaçada entre a reflexão e o reflexo. A arte como espaço da reflexão crítica deve manter suas diferenças com a ciência e a tecnologia, substituindo suas certezas pelas incertezas da sensibilidade [COUCHOT, 2003: 305-309].

A apropriação do presente pelo futuro, segundo Santos [2003: 114], está nos transportando para um espaço-tempo relativo, de invenção. A realidade ampliada desloca nossa realidade habitual, relativiza e abre possibilidades novas, certamente diferentes do já experimentado. É preciso pensar que o atual e o virtual são como dois tempos diferentes que se tornam contemporâneos, forjando um espaço entre o presente e o futuro. Como se fosse um espaço fora do tempo, continuamente em formação, informação. Nesse intervalo, a partir dele, talvez seja possível captar o sentido das transformações no bojo da digitalização.

\section{ARQUITETURA, CRÍTICA E MEDIAÇÃO DIGITAL}

E essas transformações passam pela relação com as máquinas informáticas. Segundo Guattari [1993: 178-185] a relação com a máquina não é novidade, desde as sociedades 
pré-capitalistas, com suas máquinas sociais institucionalizadas, religiosas, militares, corporativas e os processos de desenvolvimento das cidades. Na revolução industrial, prevalece o predomínio das funções, capitalizando valores abstratos que incidem sobre o saber, a sobreviver em eterno retorno sobre si mesmo: a acumulação do saber pela difusão do texto impresso, a manipulação do tempo, a força mecânica. É preciso considerar que existe uma essência maquínica que irá se encarnar em uma máquina técnica, assim como no meio social, cognitivo, ligado a essa máquina - conjuntos sociais também são máquinas, o corpo é uma máquina, há máquinas científicas, teóricas, informacionais. [GUATTARI, 1992: 51]. Assim as máquinas constituem sistemas significantes que funcionam como instrumentos de mediação da cultura.

"Explorar as possibilidades de um sistema significante implica precisamente colocar-se um limite, submeter-se à lógica do instrumento, endossar o seu projeto industrial, e o que faz um verdadeiro poeta dos meios tecnológicos é justamente subverter a função da máquina, manejá-la na contramão de sua produtividade programada. (...) O artista da era das máquinas é, como o homem da ciência, um inventor de formas e procedimentos; ele recoloca permanentemente em causa as formas fixas, as finalidades programadas, a utilização rotineira, para que o padrão esteja sempre em questionamento e as finalidades sob suspeita."

[MACHADO, 1993: 15]

Ao tratar da arquitetura realizada com a mediação das tecnologias digitais, Antonino Saggio [2001: 6-7] considera que os modelos construídos numericamente, as representações tridimensionais de objetos e espaços arquitetônicos, são por sua natureza extremamente diferentes de uma maquete tradicional, uma vez que constituem organismos como um todo 
vivo, interativo. Enquanto na maquete a informação é estática, no modelo digital todos os bits de informação estão interconectados dinamicamente. Nesse sentido, o modelo eletrônico é um recurso para estudar, testar, simular e construir. Não garante que o projeto seja bem sucedido, mas é o passo adiante mais importante na tarefa de projetar desde a descoberta da perspectiva.

"Em que medida um objeto real deveria se assemelhar aos métodos disponíveis em cada época para representá-lo? Talvez essa pergunta revele o fato de que é o conhecimento em si que o objeto arquitetônico representa. As regras básicas da trigonometria estão ilustradas nas pirâmides, os cálculos baseados na geometria estão na base do Panteão e a perda da habilidade geométrica e aritmética é evidente no interior cavernoso e instável da catedral Romanesca. Sem as regras da perspectiva não haveria o palácio ordenado da Renascença e sem os círculos do compasso as curvas de São Carlino ou Santo Ivo jamais teriam tomado forma. Finalmente, se também considerarmos as ferramentas, teremos uma chave para compreender a gênese de certos espaços. Agora, tentemos questionar nossas idéias de arquitetura considerando a ferramenta que temos conosco. E se a arquitetura contemporânea pudesse se parecer cada vez mais com o potencial dos modelos computadorizados? Gostaríamos que a flexibilidade, a inteligência, a rapidez e, como dissemos outras vezes, a interatividade dos modelos digitais fossem qualidades da obra construída. Uma propriedade não só das telas do computador, mas da arquitetura, construída exatamente assim como os conceitos de medida, ordem e centralidade da perspectiva levaram a uma arquitetura 'a sua própria imagem e semelhança'". [SAGGIO, 2001: 8-9] 
Com a mudança das ferramentas de representação da arquitetura, com a transformação do suporte em espaço dinâmico e interativo das simulações, a própria noção da arquitetura se renova, colocando em questão a posição do sujeito criador. O arquiteto deve enfrentar as máquinas para poder encontrar-se como sujeito. Para Guattari [1993: 177] a produção da subjetividade como processo singularizante e auto-referente, dependem cada vez mais de sistemas maquínicos, de assistência por computador. Se o resultado é uma aparente democratização do acesso aos saberes, é preciso, por outro lado, recusar o dilema da rejeição intransigente ou da aceitação cínica. Não faz sentido o homem querer evitar as máquinas mas é necessário perguntar porque as potencialidades processuais das máquinas informáticas só reforçaram os sistemas de alienação, a massificação midiática opressiva e as políticas consensuais. É preciso encontrar uma saída que "crie condições para o pleno desabrochar dos esboços atuais de revolução da inteligência, da sensibilidade e da criação". Segundo Guattari, só uma "passagem da era consensual midiática a uma era dissensual pós-midiática", permitirá que o planeta, vivido como inferno por 4/5 da população transforme-se em universo de encantamentos criadores. Aqueles ligados à idéia de progresso social devem se debruçar sobre essas questões [GUATTARI, 1993:187-191].

A arquitetura e aos arquitetos cabe descobrir os caminhos possíveis nos enredamentos maquínicos que permitam assumir sua vocação social. Parece urgente que o arquiteto encontre seu lugar como sujeito criador e crítico mediado por máquinas potencialmente criativas. Só assim poderá cumprir seu papel de construir os espaços que respondam às necessidades da coletividade e aos anseios de uma sociedade em constante estado de carência. Nos 
meandros das considerações dessa tese, reside o intento de construir relações que facilitem a compreensão do suporte digital como mediação fundamental para a arquitetura contemporânea. Mediação que tem antecedentes nas tecnologias numéricas desde as técnicas do Renascimento. $\mathrm{E}$ que assim, desvendadas as barreiras, possa surgir uma postura do arquiteto que remeta aos melhores momentos quando soube interpretar, representar e construir com as tecnologias disponíveis.

\section{O PERCURSO DAS DESCOBERTAS}

É preciso dizer que o percurso da tese não é linear nem determinado, por mais planejado que tenha sido. O plano constitui uma espécie de guia ou mapa, acompanhado de informações e várias possibilidades de percurso. John Cage dizia que é próprio do plano que o plano fracasse. Sem acreditar que se tenha chegado a esse ponto, também se sabe que o mapa não é o território. Como numa primeira visita a uma cidade, a cada etapa cumprida de um itinerário escolhido entre tantos, outras alternativas aparecem e o caminho se faz no decurso da viagem. Assim, a cada conceito trabalhado, a cada idéia delineada surgiu a indicação da próxima direção a seguir, do material a ser trabalhado, das amarrações necessárias. Entre aprendizados e descobertas, a matéria da tese foi sendo apreendida, conhecida, elaborada, resultando numa tradução da idéia inicial e do objeto estudado, a representação de um território próprio.

As hipóteses apresentadas em cada um dos capítulos são alguns dos possíveis com os quais a pesquisa se deparou em seu percurso. Dentre essas, há as hipóteses geradoras que permitiram iniciar o trabalho. Dessas, algumas se mostraram inadequadas, outras abriram outras frentes de investigação e 
ainda houve aquelas que não chegaram a evoluir, permanecendo como possíveis. A investigação, como atividade especulativa sobre os possíveis, permitiu encontrar hipóteses no fazer da pesquisa que se mostraram relevantes e se concretizaram como material fundamental para a consecução da tese. As hipóteses são a própria criação do trabalho, germe e fruto da atividade relacional que conduz o pensamento.

\section{$[\ldots]$}

O objetivo das considerações que constroem a pesquisa é demonstrar que o pensamento arquitetônico traduzido em teoria, experimentação e obras construídas é resultado de um processo evolutivo gradual, descontínuo e sem destino específico. Com isso procura estudar [capítulos 1 e 2] como a tecnologia digital de processamento de informação que constitui a linguagem dos computadores faz parte dessa evolução, não se apresentando como impacto ou ruptura. Toda forma de pensar, de conceber, de produzir conhecimento está ligada a tecnologias que resultam da transmissão e da assimilação próprias ao movimento da cultura, são pensamentos que se concretizam em experimentação e realização. Da arquitetura do Renascimento com a perspectiva e a visão antropocêntrica do mundo, ao movimento moderno e seu programa teleológico determinista, chega-se à complexidade das organizações sistêmicas resultado da tecnologia digital binária.

Debruçar-se sobre estas questões [capítulos 3 e 4] mostra ser importante uma vez que a própria disciplina se transforma, sofrendo influências tanto das tecnologias de informação digital como das teorias que propõem estabelecer caminhos para leitura das novas condições da produção de conhecimento. Compreender o papel dos meios computacionais 
no processo de criação da arquitetura e seus reflexos na materialização de seus objetos poderá contribuir para 0 estabelecimento de práticas que dêem conta de suas novas configurações.

Adotando como marco referencial a segunda metade do século $X X$, a pesquisa se lança em busca de possíveis antecedentes nessa evolução, procurando por possíveis interpretações que suportem essa percepção. No encadeamento do material encontram-se associações que permitem inferir que há de fato uma forma nova de pensar que resulta de outras resoluções arquitetônicas projetadas por máquinas computadoras, que são possíveis transmitir como parte da formação do futuro arquiteto.

No primeiro capítulo [Do corpo ao pensamento ou da arquitetura como função à arquitetura como relação], o postulado da arquitetura como todo difícil de Venturi revela a ressonância, no campo da arquitetura, das transformações ocorridas a partir da segunda metade do século $X X$, que acarretaram uma nova visão de mundo. A complexidade da arquitetura, assumida como questão de projeto que se revela na forma resulta de um modo de pensar diferente do modo de pensar proposto pelo movimento moderno. Significando um processo de evolução, essa outra maneira de pensar a arquitetura, uma transformação da dominante, aponta uma nova racionalidade. Assim, é possível que dos pressupostos da arquitetura moderna quando em relação com as novas percepções e teorias das ciências, germinem outros conceitos. É o caso do Modulor de Corbusier que renova a relação entre corpo e espaço, instaurando uma tecnologia analógica-digital, numérica para a gênese da arquitetura. A lógica permite encontrar a analógica de Valéry; o pensamento se define em 
diagrama seguindo Peirce; a funcionalidade maquínica possibilita encontrar uma organização orgânica; a clareza das ordenações estruturadas deixa espaço para experimentações com a forma complexa e o espaço sistêmico. Essas mudanças estabelecem outras bases para a cultura e por conseqüência para a arquitetura: relação, sistema e organização.

No segundo capítulo [Do pensamento à linguagem ou da arquitetura como estrutura à arquitetura como sistema], vê-se que essa nova racionalidade aponta para novas concepções da arquitetura. As notas de Alexander instaura as bases sistêmicas de um pensamento afinado com a ciência de caráter numérico. Assim, o programa e suas finalidades estritas impulsionam uma abordagem sintética da forma, traduzida em linguagem matemática e simbólica. As raízes da linguagem como sistema significante que constrói a possibilidade do sujeito em relação com mundo, revelam o processo gradual de mediação da cultura que passa da raiz estrutural para a raiz sistêmica. Muda a natureza do material e, em conseqüência, os procedimentos. Assentado numa base sintática o material solicita um procedimento, agora mediação que, assim, engendra forma e espaço como instâncias relacional e dialógica do sujeito. Síntese e sintaxe no processo de digitalização da cultura com raiz da linguagem como sistema.

O capítulo 3 [A linguagem da experimentação ou da arquitetura como ordem à arquitetura como processo e organização] se lança sobre a definição da tecnologia, da máquina e de suas configurações digitais que desembocam na virtualização do pensamento. Na base dessas questões está a ciência das proporções, a matemática, base do projeto moderno desde o Renascimento. A presença da matemática traduzida em sensibilidade para a criação da forma e do espaço 
arquitetônico, também se altera na medida das transformações da racionalidade. Como parte do pensamento analógico, diagramático, o pensamento matemático se reveste cada vez mais de abstração e investe sobre a tecnologia. No caso da arquitetura, o investimento recai sobre as tecnologias de representação do espaço calcadas no sistema de visão. Passa pela analogia do corpo em direção à analogia com a mente e o próprio pensamento; das ordens do renascimento para a clareza das estruturas cartesianas, rumo a complexidade relacional das organizações sistêmicas.

O quarto capítulo [Experimentação e descoberta: entre diagramações, desdobramentos e virtualidades] partindo do pressupostos dos capítulos anteriores, procura tecer os conceitos necessários para a leitura de procedimentos da arquitetura mediada pelas tecnologias numéricas. $O$ processo especulativo da arquitetura que envolve o pensamento diagramático, a analogia, o par procedimento e material, as máquinas e as tecnologias numéricas e digitais, se encontra nas possíveis concretizações com as ferramentas de processamento de informação digital, o suporte digital que configura um espaço de gênese. A filosofia de Deleuze e Guattari se articula no tecido dessas interpretações porque assume como tarefa pensar o presente, procurando sempre pensar de outro modo. Uma filosofia de resistência às complexidades do presente que inventa novas possibilidades de compreensão e que, assim, serve como esteio para a leitura dos procedimentos de invenção da arquitetura. Trata-se de uma arquitetura maquínica, em que o processo se sobrepõe à obra, como fazer reflexivo, portanto, é em direção aos procedimentos que a tese se volta. 
Se Eisenman e Gehry são tomados como referências é porque representam a possibilidade para compreender conceitualmente práticas que, por suas mãos, tornaram-se correntes. As Casas de Eisenman são diagramações maquínicas e precedem, como lógica e analógica, como pensamento e prática do projeto, a utilização do suporte digital. A abordagem dos materiais por Gehry constituem dobras e se estende sobre o suporte digital seguindo a mesma lógica experimental. Esses procedimentos convergem, se fundem e se misturam nas especulações projetivas de outros arquitetos que, embebidos em outras percepções concebem espaços imersos nas virtualidades do espaço digital. Se a leitura de tais procedimentos não é rica em apresentação de obras, ou extensa em seus exemplos, é porque pretende alcançar a clareza da concisão frente a multiplicidade e a proliferação das possibilidades de mediação numérico-digital da arquitetura.

Assim, nos movimentos sincrônicos da cultura, que se faz no avanço contínuo e gradual sobre bases que inventam novas configurações e traduções, é possível compreender a presença do digital nas práticas da arquitetura, não como ruptura, como impacto, mas como resultado de um momento explosivo da evolução de um pensamento sobre a forma, o espaço, a arquitetura. Se na tarefa de demonstrar essa relação da arquitetura com o digital, esta tese recorre a tantas referências, parecendo um tanto múltipla, de difícil definição é por ser essa a natureza de seu objeto. E se como representação do objeto, nesse exercício difícil de tradução, esse estudo não atingir com clareza necessária seu objetivo, já é, de antemão, por assumida incompetência em abarcar tamanha complexidade. 
capítulo 1

\section{do corpo ao pensamento \\ ou da arquitetura como função \\ à arquitetura como relação}


A Arquitetura é um 'todo difícil'. A afirmação de Robert Venturi faz parte do tratado em que o arquiteto toma posição a favor das complexidades e contradições da arquitetura de períodos anteriores aos anos marcados pelos cânones estabelecidos pelo movimento moderno. Escrito em 1966, Complexidade e contradição [VENTURI, 1995] manifesta uma postura diferente e divergente da atitude moderna caracterizada até aquele momento, principalmente até os anos do segundo pós-guerra. Por marcar uma tomada de posição nova, é considerado como um dos mais importantes manifestos da arquitetura do século XX [JENCKS, 1997].

A arquitetura é um sistema, uma linguagem complexa constituída por relações equívocas, às vezes não percebidas por estarem contidas nos pormenores de uma evolução sincopada, em que ordenações são desafiadas e cedem lugar às incertezas que validam significados ambíguos e contraditórios. A arquitetura, assim como toda a arte, numa abordagem diacrônica se relaciona com o passado imediato por contradição, como insurgência ou negação. Numa visão sincrônica é possível perceber momentos de turbulência nascidos na ordem estabelecida provocando sua instabilidade e descontinuidade [FERRARA, 1993: 182-192]. Reconhecendo, assim, a complexidade do significado da arquitetura, Venturi afirma que os objetos arquitetônicos formam um 'todo difícil' [VENTURI, 1995: 121-147]. Para transgredir a ordem estabelecida, no sentido de propor uma alternativa à linguagem moderna, Venturi indaga se não seria necessário: "procurar um significado nas complexidades e contradições de nosso tempo e reconhecer as limitações de sistemas? São essas, penso eu, as duas justificações para transgredir a ordem: o reconhecimento de variedade 
e confusão dentro e fora, no programa e no ambiente, e na verdade em todos os níveis de experiência; e a limitação irrevogável de todas as ordens compostas pelo homem. Quando as circunstâncias desafiam a ordem, a ordem deve ceder ou quebrar: anomalias e incertezas dão validade à arquitetura". [VENTURI, 1995: 44]

Venturi faz um trocadilho sobre a máxima de Mies Van der Rohe, que é bastante representativo dos cânones da arquitetura moderna. O 'less is more' Miesiano, que sintetiza de alguma maneira os intentos e as conquistas funcionais expressas pela forma absoluta e pelo espaço contínuo da arquitetura do movimento moderno, se transforma, pelos olhos perceptivamente críticos e plurais de Venturi, em 'less is bore'. Transposto para o português, o trocadilho perde um pouco de sua graça e sentido, uma vez que em inglês more e bore compartilham a mesma sonoridade, o mesmo número de letras e apenas uma letra diferente. A tradução brasileira da editora Martins Fontes [1995], traz: 'menos é uma chatice', muito distante da máxima de Mies em língua portuguesa: 'menos é mais'. Talvez a aproximação seria melhor utilizando um substantivo menos usual, com significado mais ambíguo e menos direto, mas que pela sonoridade garantiria uma relação mais direta com o original. Ao 'menos é mais' poderia se contrapor 'menos é maça', de maçar (enfadar, amolar), de maçante (aborrecido, tedioso), de maçada (fastidiosa, cansativa). O equívoco, é claro, estaria em ter que explicar o que significa a palavra escolhida, uma vez que é pouco conhecida, nada usual e com significados ambíguos: maça também pode ser arma, pilão; maçar pode ser golpear; maçante pode ser cacete; maçada pode ser trapaça. Porém, no mínimo, 'menos é maçante', ainda que não tenha a mesma qualidade de trocadilho que se percebe na língua inglesa, more trocado por 
bore, é mais aberto a interpretações e, por conseqüência propenso a várias compreensões.

Esse pequeno e falho exercício de tradução, da procura de pormenores que possam atribuir significados a uma expressão que os contém em profusão, dada a sua extensão e pertinência histórica, um esmero que pode soar como fora de lugar, equívoco, ilustra as intenções de Venturi. O que ele quer é contrapor à arquitetura moderna, à sua homogenização, ao seu academicismo, uma abordagem inclusiva e atenta aos detalhes. E o faz através da leitura e análise visual de obras dos mais diversos períodos da história. Uma leitura baseada nos significados dos elementos arquitetônicos, na valorização da diferença, dos pormenores que resgatam o valor simbólico e a tradição, que aceitam as complexidades existentes nas obras e exploram as contradições das articulações de elementos e espaços como artifícios de linguagem.

Esse manifesto da arquitetura equívoca [MONTANER, 1993], se funda na arquitetura como fato visual, como fato perceptivo, como meio comunicativo cuja mensagem se faz de significados ambíguos. Ao longo do livro, Venturi aborda temas que enfatizam a complexidade e a contradição da arquitetura que podem ser interpretadas nas ambigüidades de elementos que expressam mais de um significado, na capacidade de espaços possuírem duplas funções, nas transgressões das linguagens de cada escola arquitetônica.

Venturi faz referência aos vários campos da cultura, entre outros a arte Pop, a poesia de T.S. Elliot e as teorias sobre complexidade de Herbert Simon [1969]. Ele manifesta sua preferência: 
"por uma arquitetura complexa e contraditória, baseada

na riqueza e na ambigüidade da experiência moderna", e mais adiante, "ao aceitar a contradição, assim como a complexidade, tenho em vista a vitalidade, tanto quanto a validade". [VENTURI, 1995: 6-7]

Dos arquitetos modernos seus contemporâneos, admira Kahn, com quem trabalhou, Aalto e Corbusier, arquitetos que, segundo ele, rejeitaram a simplificação redutora e encontraram na lógica da razão elementos para a criação de espaços que em sua aparente simplicidade escondiam uma ordem

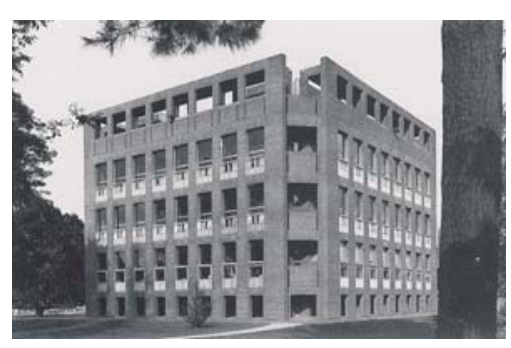
complexa.

Sua posição não se resume a uma simples reação ao moderno, mas leva em conta a necessidade de rever os meios de expressão da arquitetura e reconhecer a complexidade crescente dos programas com extensos problemas funcionais, e por outro lado, compreender os programas em que a produção da arquitetura envolve meios super simples, mas a finalidade, como parte da experiência contemporânea, pode ser extremamente complexa [VENTURI, 1995: 8-9]. Além disso, Jencks [1987, 87-89; 154-160] considera que Venturi foi o primeiro arquiteto a utilizar elementos de caráter decorativo de maneira contestadora e assim teria inaugurado uma arquitetura comunicativa.

Mas porque Venturi pôde escrever sobre uma outra maneira de ver a arquitetura? O que o levou a reconhecer as ambigüidades, as incertezas, as relações que perfazem a difícil unidade do todo arquitetônico? Porque surgiu a possibilidade desse outro olhar em meados do século $X X$ ? Em que contexto estava inserida tal proposição? Sobre que conceitos se apoiou? Que outros acontecimentos cercam o campo da arquitetura? 


\section{A DOMINANTE EM MUTAÇÃO}

A partir da segunda metade do século $X X$, transformações significativas ocorrem nos campos da ciência, da tecnologia e da arte. Estas transformações, que repercutem e se desdobram ainda hoje, alteram a visão de mundo calcada nos princípios do racionalismo que tem origem na cultura clássica. Cabe, portanto, questionar esta outra visão de mundo que se estabelece sobre aquela dominante.

A idéia de moderno, seu ideal clássico, está calcado no cartesiano, no ordenado, no absoluto. Sua ideologia, seu pensamento é determinado por leis estáticas e imutáveis. A visão de mundo é linear, centrada e orientada pelos princípios da causalidade e determinação. Essa é a cultura dominante. Segundo Roman Jakobson [1977: 77-85] a dominante é imperativa e hierarquizante. Apesar de ser um conceito desenvolvido para a análise da poética, é considerado fundamental e dos mais importantes da teoria formalista russa e pode ser aplicado a outros campos do conhecimento. Jakobson define a dominante como:

"elemento determinante de uma obra: ela governa, determina e transforma os outros elementos. É ela que garante a coesão da estrutura. A dominante especifica a obra". [JAKOBSON, 1977: 77]

O significado do conceito é mais amplo do que a simples aplicação na leitura e análise de uma obra podendo alcançar um domínio mais vasto. Ao analisar o conceito de dominante em seu livro A Estratégia dos Signos [1981], Lucrécia D’Aléssio Ferrara observa que:

"assiste-se, pois, na caracterização de uma dominante, a uma evolução que atinge a produção de um autor, as relações entre autores ou entre diversas artes e esta 
evolução caracteriza uma possível leitura da história da arte". [FERRARA, 1981: 40-41]

E mais adiante afirma que, para a arte moderna é a linguagem que se torna dominante. Linguagem aqui entendida como sistema de signos que medeia a relação de conhecimento do mundo. Mediação como processo dinâmico, reflexivo, que resulta em representações que evoluem na medida correspondente ao processo de mudanças culturais. Seguindo essas indicações, seria possível imaginar uma hierarquia, uma dominante entre as diversas visões de mundo que moldam a cultura e seus signos. Poder-se-ia indagar se o mesmo movimento evolutivo se aplicaria às artes e à arquitetura e suas manifestações baseadas nos princípios da cultura. É Ferrara quem lança a pergunta:

"Seria possível admitir uma evolução entre as artes que caminhasse de uma série basicamente lógica e linear para outra, eminentemente analógica e relacional?" [FERRARA, 1981: 41]

Se esta cultura se transforma ao substituir o desejo de objetividade e estabilidade no sentido de ordenar as formulações criadoras através do pensamento sistêmico, faz-se necessário definir, ou ao menos delinear, qual a ordem ou estrutura dominante que se desmonta e, principalmente, que sistema ou organização se funda em seu lugar, permitindo à arquitetura novos desdobramentos. A dificuldade de delinear esse outro contexto cultural está precisamente na natureza do pensamento que passa a se impor como dominante. Sua definição pode ser tão imprecisa e aberta quanto a freqüência e a amplitude com que oscilam e variam seus constituintes. $\mathrm{O}$ caráter da dominante passa a ser o movimento e a mudança. 
Várias são as leituras realizadas sobre a arquitetura do período posterior à segunda guerra mundial. Várias também foram as designações na tentativa de caracterizar essa produção: O último capítulo da arquitetura moderna, de Leonardo Benévolo [1985], Depois do movimento moderno e $A$ modernidade superada, de Josep Maria Montaner [1993; 2001] ou O lugar da arquitetura depois dos modernos, de Otília Arantes [1993], são apenas alguns exemplos. Historiadores, críticos e analistas, arquitetos ou não, não importa suas filiações e referências, a favor ou contra o movimento, seus protagonistas e suas concepções, todos concordam com o fato de que, na segunda metade do século $X X$, algo mudou na produção arquitetônica. De fato, o contexto que se desenha após o conflito na Europa, difere bastante daquele configurado e consolidado a partir da segunda década daquele século.

A partir dos anos 30, motivada pelas vanguardas, a arquitetura dos primeiros anos do século 20 postula-se internacional. O conjunto de suas obras e arquitetos, pela motivação e objetivos comuns, passa a ser designado como movimento moderno. Dois fatores podem ser apontados como responsáveis pela internacionalização dos princípios racionalista e funcionalista adotados pela arquitetura moderna como modelo a ser propagado e defendido. Por um lado os C.I.A.M., Congressos Internacionais de Arquitetura Moderna, que ocorrem a partir de 1928, reunindo os expoentes europeus em torno de temas centrais para a unidade do ideário moderno e, por outro lado, a exposição promovida por Henry-Russel Hitchcock e Philip Johnson em 1932, no MoMA, Museu de Arte Moderna de Nova lorque, reunindo as obras mais significativas da produção arquitetônica da Europa e dos Estados Unidos 
[BENEVOLO, 1985: 15-22; FRAMPTON, 1997: 327-339]. O

primeiro serve como espaço de discussão e sedimentação das idéias propulsoras da ideologia da arquitetura moderna, de seu projeto utópico; o segundo aparece como difusor da imagem dessa arquitetura como linguagem codificada a ser apreciada, apreendida e reproduzida. Um atribui ao projeto utópico o caráter de movimento e o outro libera a sua internacionalização.

Assim, o projeto utópico do movimento moderno assume um duplo caráter. Por um lado, ao determinar os elementos e as combinações de sua linguagem, pode se adaptar a todo lugar tomando cores das mais diversas, de todos os lugares e de nenhum. Utópico, sem lugar. Por outro lado, esse projeto utópico é transformado em programa e deve ser alcançado inexoravelmente. De projeto teleológico como processo integrado concebido a par do devir da história, a utopia se transforma em programação, préordenação calculada de todas as soluções regidas pela mesma determinação visando o mesmo fim. O projeto é, então, um fim em si mesmo [ARGAN, 1992: 251-267; 2001: 7-63]. A partir daí é possível compreender a diferença e a oposição entre modernismo e modernidade.

"Na caracterização de um conceito, o Modernismo é um programa que deseja controlar o pensamento e a ação dos homens dentro de uma matriz universal criadora de uma felicidade inexorável. (...) A modernidade sugere uma outra postura epistemológica na qual o homem e sua razão enfrentam e aderem a um mundo em transformação constante mas indeterminada porque depende da mútua interação homem / natureza e das possíveis, diversas, mas não necessariamente respostas provocadas por essa interação". [FERRARA, 2000: 173]

Assentado o referencial do que se constituiria como arquitetura moderna, identificado, principalmente, na obra de Le 
Corbusier, Walter Gropius, Mies Van der Rohe e Frank Lloyd Wright, embora esse último sem uma participação tão efetiva para sua sustentação, o movimento moderno preconiza princípios e cristaliza métodos e objetivos. A linguagem da arquitetura moderna se propaga pelos continentes e países, encontrando reações e prosseguimentos diversos. Começam a aparecer resoluções particulares e interpretações contextuais dos princípios preconizados. Ao disseminar seu ideário e sua linguagem por todas as partes, o moderno como movimento, abriu possibilidades para expressões locais e regionais, ao mesmo tempo em que estabeleceu uma gramática que, enquanto se desgasta, também se esgarça e ganha novos sentidos.

Depois da segunda guerra, as utopias dos anos 10 e 20 dão lugar às distopias. Os arquitetos percebem que os ideais estabelecidos e perseguidos ao longo das quatro primeiras décadas do século não serão plenamente satisfeitos. A dimensão teleológica do projeto moderno, seu caráter programático e utópico de redimir os males sociais através da arquitetura, instaurando através desta a democracia e tornando os homens livres, perde de vista suas motivações e razões. As condições de desemprego e recessão do pré-guerra, de descontentamento social e instabilidade política, foram agravadas pelos bombardeios que resultaram na destruição das principais cidades européias. As políticas de auxílio a reconstrução impostas no pós-guerra procuraram se aliar à necessidade de recuperação de um estado de bem estar social, facilitando a preservação da ordem capitalista antes ameaçada. A reconstrução da Europa e sua reordenação política possibilitaram a ampliação do fluxo de investimentos e de comércio mundial, permitindo a consolidação do poder político 
apoiado na idéia de uma democracia econômica de massa [HARVEY, 1993: 71-112].

A racionalidade técnica e burocrática do sistema político e econômico posto em prática encontrou no princípio do funcionalismo da linguagem da arquitetura moderna, um aliado para a necessidade pragmática de sua economia de produção. As soluções da arquitetura moderna para esses dilemas do pós-guerra, suas contribuições com projetos de habitação coletiva e recuperação dos tecidos urbanos, funcionaram como modelo ideal do pensamento econômico que, com o passar do tempo, se mostrou hegemônico [HARVEY, 1993: 121-134]. O otimismo dos arquitetos com o projeto utópico lapidado nas décadas anteriores cede lugar ao pessimismo e à consciência das limitações do ideal de liberdade que revestia a arquitetura até então.

\section{AS ORDENS DA RAZÃO}

Seria desnecessário e até redundante discorrer sobre os conceitos que determinam a arquitetura moderna até meados dos anos 50 do século XX, tarefa já cumprida inúmeras vezes de maneira competente. Mas para demonstrar a passagem que se opera na dominante, uma definição se faz importante para comparar com aquilo que toma seu lugar. Essa definição se vale de três elementos que podem ser confrontados: até os anos 50, aproximadamente, teríamos o tripé função, estrutura e ordem, em contrapartida à tríade relação, sistema e organização que começa a se impor na segunda metade do século.

O racionalismo pressupõe uma ordem harmônica e precisa, em que cada elemento da estrutura tem sua função 
clara e definida. A clareza da disposição dos elementos, que têm seus objetivos determinados a priori, garante a precisão da informação, decorrendo daí a noção de funcionalismo. A estrutura é, portanto, o próprio conteúdo, uma vez que ordenada logicamente, em que cada função é compreendida na sua interação com o todo. Assim, a forma segue a função, que se traduz em qualidade [FERRARA, 1981: 66-72].

A arquitetura moderna dentro desse contexto, desenvolve uma linguagem afinada com esses preceitos. As pesquisas de novos materiais construtivos, como o ferro, 0 vidro, o aço e o concreto, e a conseqüente pesquisa de sua resistência física [ZEVI, 1945: 18], aliada ao sistema de representação matemático e linear da perspectiva que representa a estrutura hierarquizada da cultura [FERRARA, 2000: 163-174], leva a arquitetura a se despir de qualquer acessório em favor do significado da própria estrutura e de sua expressa racionalidade e funcionalidade. A arquitetura moderna "deve falar através da pureza geométrica de sua exclusiva estrutura arquitetônica". [FERRARA, 1981: 13]

O moderno com origens no Renascimento, atravessa e consolida raízes nos séculos XVIII e XIX com a ascensão da burguesia e a sociedade industrial. A atitude moderna é marcada pela afirmação das certezas e pela busca da ordem, imbuída pelas faculdades da razão. Tais concepções viram o século XX ressoando pelos anos das vanguardas revolucionárias, que, em sintonia com os novos paradigmas lançados por vários campos do conhecimento, ainda se ressentem de dogmas cristalizados ao longo dos séculos precedentes. A Teoria da relatividade, a mecânica quântica, o princípio de indeterminação, a segunda revolução industrial 
eletroeletrônica convivem com as certezas inabaláveis da ordem racionalista.

\section{A ORGANIZAÇÃO DAS INCERTEZAS}

A partir da segunda metade do século $X X$, outra forma de ver e se relacionar com mundo pode ser descrita como indefinida e aberta, carregada de nuances, processual e relacional e, assim reconhecedora de suas imprecisões, turbulências e oscilações. Fundadora de uma organização repleta de complexidades.

As façanhas científicas do início do século XX, a teoria da relatividade e a mecânica quântica, apesar de seu caráter revolucionário, ainda estavam filiadas à tradição clássica. Essa tradição foi posta em questão pelas descobertas experimentais da física a partir dos anos 50: a instabilidade das partículas, as estruturas de não-equlíbrio, a evolução do universo. Conceitos novos como caos e atrator estranho aparecem como instrumentos de pensamento, que permitem aproximações novas entre campos distintos [PRIGOGINE e STENGERS, 1992: 11-21].

A estabilidade e a determinação da visão clássica do mundo, passa a dar lugar a percepção da complexidade das relações, implicando em organizações sistêmicas, abertas ao reconhecimento da ocorrência de processos indeterminados e irreversíveis. No século XIX, quando Boltzmann define a entropia através da transposição da teoria evolucionista de Darwin para a física, descobre a irreversibilidade dos processos, que aumentam em complexidade na medida de sua evolução. Desde então, a simetria da flecha do tempo é 
quebrada, estabelecendo uma clara distinção entre passado e futuro. Estamos diante do fim das certezas [PRIGOGINE, 1996].

A cibernética e a teoria da informação assimilam o princípio da entropia, trazendo para as ciências humanas e as artes a dimensão do relacional e do processual [FERRARA, 1993: 167-192]. Segundo Prigogine e Stengers [1992: 57] a definição de relação faz parte da própria definição de sistema, que assume diferentes regimes ou estados. Esses regimes ou estados permitem precisar as relações entre o todo e as partes que o caracterizam, num processo dinâmico e complexo. Por sua vez, os sistemas em relação pressupõem uma lógica de organização. A organização se estabelece por relações sistêmicas. Segundo Ferrara:

"toda organização é lógica, é linguagem produzida por signos que, por sua vez, são representações dessa específica maneira de organizar. Essa lógica ou linguagem é tão múltipla, variada e complexa quantos e como forem os sistemas pelos quais se organiza". [FERRARA, 2000: 153]

Em lugar de função, relação, em lugar de estrutura, sistema, em lugar de ordem, organização. Começa a surgir uma nova racionalidade, capaz de reconhecer ambigüidades, complexidades e contradições. Delimitado este contexto, é possível se debruçar especificamente sobre a arquitetura e suas transformações.

\section{UMA NOVA RACIONALIDADE}

De todas as artes talvez seja a arquitetura a que menos pode prescindir da racionalidade, devido ao seu caráter pragmático e construtivo. Entretanto, o conceito de racionalismo não é constante na história da arquitetura, sofrendo mudanças 
dependendo do período e das influências da cultura dominante. Uma definição mais genérica do conceito deve ser assumida, que implica ser a arquitetura resultado da aplicação de certas regras estabelecidas pela razão. Por volta dos anos 50 , há uma "liberalização" das concepções racionalistas que, sem descartar o racionalismo como fundamento, procura humanizá-lo [COLQUHOUN, 2004: 67-95].

Essa procura por humanizar a razão, passa entre outras coisas, por abrandar os paradigmas trazidos no bojo da industrialização, que permitiu forjar uma linguagem e uma identidade para a concepção da arquitetura, como dito anteriormente, baseada na funcionalidade das estruturas. Um desses paradigmas, o funcionalismo, tão caro quanto essencial à conformação da linguagem do movimento moderno, é também tão variado em acepções quanto os racionalismos em arquitetura. Como chamou a atenção Peter Collins, várias analogias foram desenvolvidas a partir da idéia de funcionalismo, sendo as mais importantes as analogias com a mecânica e com a biologia [COLLINS, 1970: 151-169].

Essas duas analogias abrem duas vertentes da arquitetura moderna que, de maneira geral, se contrapõem. $\mathrm{Na}$ Europa do entre guerras, pelos motivos ideológicos e práticos da conjuntura econômica, política e social, prevalece a analogia mecânica, maquínica. Foi Bruno Zevi, nos anos 40, quem apontou para a possibilidade de mudanças em outra direção ao criticar a arquitetura moderna, fria, programática e anônima. Em seu ensaio Por uma arquitetura orgânica [ZEVI, 1945], que indica no subtítulo tratar-se de uma investigação sobre o desenvolvimento do pensamento arquitetônico nos últimos 50 anos, defende o surgimento necessário de uma arquitetura 
orgânica. Tal arquitetura, aberta e humanizada teria em Frank Lloyd Wright um de seus atores mais representativos.

Entretanto, o caso mais significativo dessa humanização da razão, ou pelo menos um caso que toma um viés menos evidente para assumir essa nova racionalidade que surge e começa a se afirmar como uma possibilidade para a concepção da arquitetura moderna, talvez seja Le Corbusier. Embora tanto discurso quanto obra contenham uma certa dose de ambigüidade, há uma mudança fundamental em Corbusier, um momento de transição, uma passagem que mescla e funde a analogia da máquina, funcional, com a analogia do corpo, relacional.

Entende-se por analogia a determinação de uma coisa pelo conhecimento de outra, por semelhança, sendo que a analogia pode ser compreendida como a própria identidade dessa relação. Como diz Myrna Nascimento [2002: 12-14] em sua tese Arquiteturas do pensamento, os elementos associados por analogia, se relacionam de forma singular com sua sintaxe, com seu próprio modo de se constituir, através do pensamento. Segundo Paul Valéry [1999: 139], essa faculdade de comparar dois objetos seria o termo inferior da analogia. Ao definir a analogia ao longo de uma série de páginas do ensaio Introdução ao método de Leonardo da Vinci, [1999: 134-145 e ss.], Valéry diz que:

"é precisamente apenas a faculdade de variar as imagens, combiná-las, fazer coexistir a parte de uma com a parte da outra e perceber, voluntariamente ou não, a ligação de suas estruturas. E isso torna indescritível o espírito, que é seu lugar. As palavras perdem sua virtude. Lá, elas se formam, brilham diante de seus olhos: é ele que nos descreve as palavras. O homem leva, assim, visões, cuja força faz a dele. Relaciona sua história a elas. São seu lugar geométrico." [VALÉRY, 1999: 135] 
Essa faculdade de relacionar, de associar, seria, ela mesma, uma analogia do pensar em si, da estrutura do pensamento, pois, ainda segundo diz Valéry ao comentar seu próprio ensaio, "todo pensamento exige que se tome uma coisa por outra, um segundo por um ano" [VALÉRY, 1998: 243], pois o pensamento "não passa de uma tentativa de passar da desordem para a ordem, precisando das ocasiões da primeira - e de modelos da segunda" [VALÉRY, 1999: 143].

É interessante estender essa idéia de pensamento como analogia, relembrando suas raízes latinas [CHAUÍ, 2002: 152153]. Tanto pensar como pensamento derivam do verbo pendere, que significa suspender, ficar em suspenso. Portanto, pensamento é esse momento em que os julgamentos ficam suspensos, permitindo associar coisas por analogia. No estado de suspensão o pensamento está embebido com as qualidades da analogia. Diferente do cogito Cartesiano, que animou os pressupostos da ideologia moderna, que tem dupla raiz, também no Latim, nos verbos agere: empurrar para diante de si e agitare: empurrar para frente. Cogitar enquanto pensar é colocar algo diante de si para examinar, o que pressupõe o conceito como parte integrante dessa postura, significando uma atitude racionalizada.

\section{DAS MÁQUINAS MECÂNICAS ÀS MÁQUINAS DO PENSAMENTO}

Sem perder de vista Corbusier, suas mudanças de concepção e suas experimentações de linguagem, é necessário dizer que a própria idéia de máquina e a concepção de sua natureza mecânica passa por transformações e sofre alterações significativas nos anos vizinhos ao pré e ao pós-segunda guerra. Será quase impossível saber se essas idéias influenciaram ou não o pensamento e a obra do arquiteto, mas uma breve explanação servirá de suporte para demonstrar a 
humanização da razão, da redefinição da máquina como paradigma e sua relação com o homem, com o corpo, com a vida, presente em alguns dos projetos de Corbusier do pósguerra.

De fato, tanto máquinas quanto seres vivos, sua concepção e a compreensão de sua natureza, estão em transformação. As máquinas e suas funções automáticas comandadas por instruções objetivas, os seres vivos e seu comportamento associativo e capaz de fazer escolhas e decisões. As pesquisas sobre os dois campos se encontram no estudo do pensamento humano e nas possibilidades de dotar máquinas de comportamentos humanos, simulando seres vivos. Nesse cruzamento surge uma nova disciplina, as ciências cognitivas [DUPUY, 1995].

Um dos responsáveis por novas idéias no sentido de superar a relação meramente funcional entre máquinas e seres vivos, foi Norbert Wiener. Matemático, Wiener cunhou o termo 'Cibernética' para designar o estudo dessas relações, tomando conceitos de vários campos: engenharia mecânica, eletrônica, ciência da computação, biologia, física, psicologia, neurociência e teoria da informação. Toma conceitos e os transforma de acordo com seus objetivos e sua aplicabilidade, aproxima o funcionamento das máquinas ao comportamento dos organismos vivos, configurando uma ciência interdisciplinar. Segundo Wiener [2000], o funcionamento físico de máquinas e seres vivos é similar quando se trata da tarefa de controlar a entropia através da retroalimentação. Ambos recolhem informação do exterior através de receptores sensoriais, são transformadas internamente e então utilizadas para o processo de funcionamento do organismo, que se auto-organiza e se reorganiza. 
O estudo de sistemas e a maneira pela qual se comunicam com o mundo exterior ou a maneira pela qual podem receber informações, a definição de entradas e saídas, compreender as regras que regulam tais sistemas; o processamento das informações pelo sistema e suas possíveis correções no sentido de automatizar suas ações, agora são passíveis de controle externo. Algumas das intenções iniciais da Cibernética ampliaram-se e ramificaram-se, infiltrando-se nos diversos campos do conhecimento, com maior ou menor presença, dependendo da época. Se não influenciou diretamente a mudança de paradigma da idéia da máquina, ao enredá-las aos seres vivos, dotou as máquinas de outro estatuto.

Poucos anos antes, em 1936, outro matemático, Alan Turing, definiu conceitualmente uma máquina capaz de executar qualquer tarefa. Tal máquina universal foi chamada de máquina de Turing. Descrita de forma simples, essa máquina compreende três órgãos: a máquina em si que pode assumir estados pré-definidos por uma lista limitada; uma fita de tamanho indeterminado, que representa a memória, dividida em casas que podem conter símbolos; e um cabeçote capaz de ler, escrever ou apagar informações e se deslocar para a direita, para a esquerda ou permanecer parada, dependendo das marcas em cada casa da fita. A máquina eventualmente muda de estado, mantém ou muda o conteúdo da casa lida, desloca o cabeçote à direita ou à esquerda ou permanece no mesmo lugar. Segundo Dupuy [1995: 28-38], a máquina de Turing é um modelo do pensamento simbólico.

Turing estabeleceu um princípio geral para o funcionamento dos computadores, apoiado no conceito matemático de procedimento efetivo. As instruções à máquina 
devem ser dadas passo a passo, um algoritmo, numa sucessão, que à medida de sua execução, transforma o estado da máquina. Ou seja, um número finito de instruções não ambíguas garante atingir um objetivo ou executar, por uma série de combinações, uma série infinita de operações. Turing transformou o funcionamento da máquina em fórmula matemática, máquina em pensamento abstrato. Sua invenção demonstrou que qualquer tarefa, especialmente aquelas tarefas mentais, pode ser computada, executada por um computador, ao mesmo tempo em que mostrou que todo computador pode ser reduzido a uma máquina de Turing. Por isso também foi chamada de máquina universal de Turing. Os computadores atuais nada mais são do que máquinas de Turing sofisticadas.

Se a máquina foi transformada em pensamento, em modelo matemático abstrato, aplicável a qualquer tarefa que se deseje executar mecânica e automaticamente, restava a Turing o desafio de provar que uma máquina seria capaz de resolver problemas e tarefas do pensamento, tomando seu lugar, ou entrando em concorrência com esse. Em 1950 Turing formula uma tese para provar que as máquinas podem pensar. Em um artigo controverso e polêmico, Computing machinery and intelligence, traduzido para o português como O jogo da imitação [TURING apud EPSTEIN, 1973], que se mantém como referência quando se trata de inteligência artificial, ciência da computação e ciências cognitivas, ele concebe um jogo, que chamou de jogo da imitação, feito a três: uma máquina, um ser humano e um interrogador. O interrogador, sem ter contato com os dois outros participantes, deve determinar quem é quem, através das respostas às suas perguntas feitas por um teletipo. A estratégia da máquina é induzir o interrogador ao erro, fazendo-se passar por humano [DUPUY, 1995: 38-41]. 
Enquanto as máquinas passam da natureza energética e da força propulsora e produtora para a natureza da informação e do processamento de sinais e abstrações matemáticas, com potencial para simular comportamentos humanos, os seres vivos, o corpo e a mente, a partir da Cibernética de Wiener, também passam a ser vistos como padrões de organização equivalentes às máquinas, como sistemas que operam a partir da interpretação e da reprodução de sinais [SANTAELLA, 2003: 181-183].

Assim, se a arquitetura do movimento moderno tem como paradigma a máquina mecânica que atua como extensão das forças do homem incrementadas exponencialmente pela energia, a máquina que desponta como possibilidade para os anos do pós-guerra é um sistema de associar, um pensar, que estabelece uma máquina abstrata, um sistema que funciona baseado em um processo que relaciona informações passo a passo, capaz de executar tarefas mimetizando o raciocínio e até de funcionar simulando a mente humana. É extensão da mente, do pensamento. Da extensão mecânica à extensão cognitiva.

\section{DA MÁQUINA COMO REFERÊNCIA AO CORPO COMO PARTIDO}

Agora é possível olhar atentamente para Le Corbusier, procurando circunscrever o arcabouço cultural e científico que permite interpretar sua obra do imediato pós-guerra como representante pioneiro da arquitetura complexa de que fala Venturi. Carregando os referenciais da arquitetura moderna que remete ao mundo clássico, mas imbuído das transformações científicas, se sintoniza com uma nova dominante cultural e colabora para a realização de transformações na maneira de conceber a arquitetura. Jencks [2000] defende a tese de que 
Corbusier participa como protagonista em todos os capítulos da contínua revolução da arquitetura moderna. Não se pode afirmar até que ponto Corbusier ou outros arquitetos contemporâneos a Wiener tinham conhecimento de suas teorias, mas a máquina deixa de ser, gradativamente, a imagem mais-que-perfeita perseguida pela arquitetura, que assim se humaniza e se abre para outras relações e revoluções. Revolução no sentido disposto por Thomas Kuhn [2000], do conhecimento que caminha à medida que as teorias e as práticas, no caso da arquitetura, se tornam modelos, e com o passar do tempo não respondem mais aos anseios sociais, tecnológicos e ideológicos de determinado momento.

É preciso lembrar que Corbusier foi um dos maiores defensores do pensamento cartesiano aplicado à arquitetura. Dizia que era necessário estabelecer padrões, standarts, modelos que permitissem a reprodução industrializada. Dessa forma, a estética moderna atenderia às necessidades sócioeconômicas do homem da época. Sua referência, repetida em diversos de seus escritos, era a produção industrial e suas realizações, as máquinas, as belas máquinas como o avião e o transatlântico.

Seu ideal era projetar, no primeiro momento, uma arquitetura funcional e econômica, industrializada e assim reprodutível em série, mas que deveria, necessariamente ter tanto impacto quanto os feitos da engenharia mecânica. Corbusier acreditava que havia uma identidade ontológica entre ciência e arte, entre tecnologia e criação poética [COULQUHOUN, 2004: 159-182]. Essa é uma das crenças que o levam a declarar, em Por uma arquitetura, publicado em 1923, que a casa é uma máquina de morar [LE CORBUSIER, 2002]. A máquina de morar tinha como pressuposto um método 
ideativo baseado na modulação dos elementos constituintes do espaço. A organização do espaço e suas relações de medida seriam derivadas dos módulos construtivos aplicados a construção da arquitetura. Segundo Argan [2001: 93-102], uma das grandes invenções da arquitetura moderna foi o móduloobjeto, à diferença do módulo-medida da tradição clássica renascentista.

Essa vai ser uma das mudanças no pensamento arquitetônico de Le Corbusier com a idéia do Modulor. Mudança e contradição. Uma passagem do pensamento arquitetônico que se desenvolve a partir do módulo-objeto, dos elementos standarts, para um pensamento que se processa por meio de variáveis, modulações combinatórias, baseadas nas dimensões do corpo. Essa passagem como fluxo e não mudança, não exclui o pensamento anterior, mas agrega-o a um novo método ideativo, com a intenção de demonstrar ser possível associar produção em massa padronizada e liberdade de criação. [COULQU-HOUN, 2004: 159-182]. Segundo Choay [1960], depois da II guerra a plástica de Corbusier adquire maior generosidade, as formas continuam simples, mas se combinam em maravilhosas invenções:

“Tendo apaixonadamente compreendido e amado a era da máquina na qual nasceu, e tendo construído para a maioria ele provou que é possível reconciliar estandartização universal e a mais pura poesia. (...) A maior contribuição de Le Corbusier para a arquitetura do século XX é provavelmente ter redescoberto o homem que se perdeu no desenvolvimento frenético da técnica." [CHOAY, 1960: 22]

A repercussão da proposição do Modulor entre os críticos e os arquitetos não foi das melhores. A grande maioria considerou a proposta de Corbusier demasiado generalizante, acusando-o de idealizar um homem universal a partir de um 
homem particular. Para uns, seria uma manifestação tardia do legado clássico da busca de harmonia por procedimentos racionais [SUMMERSON, 1963, p.46]. Para outros é a tradução moderna do homem ideal que balizou a arquitetura moderna vanguardista até 1945 [MONTANER, 1993: 18].

Contudo, é possível encontrar vozes dissonantes ao largo do coro dominante. Em 1958, Argan em texto sobre a industrialização dos procedimentos da arquitetura, diz que o Modulor, assim como o módulo desde o Renascimento, não é uma forma básica, mas é uma virtualidade formal, porque é meio que antecede o desígnio. Desse modo, deve ser considerado como um princípio de projetação, baseado em um método ideativo, um sistema de relações e proporções. Um método considerado como procedimento, como meio que servirá para organizar o conjunto de dados que compõe o projeto, a idéia, o plano [ARGAN, 2001: 97]. Em escrito posterior, dos anos 60, sobre a crise da arte, Argan define 0 projeto como a forma específica da intenção e como tal, como escolha e designação de valores, define o método [ARGAN, 2001: 51-52]. Já Vincent Scully [2002: 100] diz que o homem de Corbusier descende do homem Vitruviano, mas ao contrário de sua estaticidade, o Modulor faz um gesto sem limites, em direção ao infinito, por se constituir como sistema de relações que permite a organização do espaço por inúmeras combinações.

\section{O ESPÍRITO DO MODULOR}

Uma entre as várias razões que motivaram Corbusier a inventar o Modulor foi a necessidade, no imediato pós-guerra, de reconstrução das cidades afetadas pelos conflitos. A industrialização teria um papel fundamental para que a 
arquitetura pudesse realizar essa tarefa, uma vez que exige a definição de padrões e standarts, modelos reproduzíveis em larga escala e padrão de economia. Nesse período, Corbusier mostra sua intensa vitalidade e preocupação social, ao investir sobre pesquisas de normatização da construção, que já vinha desenvolvendo desde os anos 10 e 20, como demonstrou com a Casa Dominó (1914) e com os trabalhos expostos no Pavilhão do Espírito Novo (1921). Durante a ocupação, sem encomendas de projetos, o arquiteto à procura de uma escala ideal para a arquitetura, o espaço e seus elementos, passíveis de produção industrial, pinta na parede de seu ateliê um painel com uma escala métrica de aproximadamente quatro metros para confrontar com seu próprio corpo. Um dos objetivos dessa experimentação era determinar uma medida que pudesse tomar o lugar, unir ou sintetizar as duas escalas de medida, a métrica e polegadas, que tantas dificuldades criava para a criação de standarts de caráter internacional, possibilitando otimizar a reconstrução e a construção industrializada.

Para Corbusier, os dois sistemas de medida estão baseados em cifras abstratas, incapazes de qualificar um intervalo, apesar da analogia entre o sistema de polegadas com as partes do corpo. Tais sistemas de cifras representam o pensamento moderno funcional da racionalidade técnica e burocrática que abandonou padrões de medidas baseados em analogias humanas, como o Homem Vitruviano. Assim, entendia ser preciso encontrar um sistema de medidas que fosse o mais adequado para as necessidades da construção industrializada. Por outro lado, o arquiteto procura relações com outras linguagens e conclui que as linguagens visuais não contam com tecnologias de mensuração, como a música. 
Esse não é um intento novo na história da arquitetura, como demonstrou Rudolph Wittkower [1958] ao estudar a arquitetura na idade do humanismo. A arquitetura do Renascimento se baseava nas proporções platônicas e pitagóricas que concebiam a harmonia por expressões algébricas que encontravam sua mais perfeita tradução na música. Se as relações harmônicas agradavam os ouvidos deveriam agradar também aos olhos e a analogia entre proporções auditivas e visuais formou um vasto campo de investigação para a época, assunto que Wittkower dedica um capítulo [WITTKOWER, 1958: 102-153]. Se a música era construída segundo regras admissíveis e efetivas, abertas à diversidade de possibilidades, simples, manipulável e acessível, baseadas em relações matemáticas, por que não a pintura e a arquitetura? Le Corbusier declarou por diversas vezes seu apreço pela matemática, que fez refletir na maneira como concebeu seus projetos. Nos anos 20 propôs que a lógica matemática deveria reger as manifestações modernas:

"A geometria é a base. (...) Ela nos traz as elevadas satisfações da matemática. (...) As artes e o pensamento moderno, depois de um século de análise, buscam mais além do fato acidental e a geometria os conduz a uma ordem matemática, atitude cada vez mais generalizada." [LE CORBUSIER, 1992: VII]

Essa ligação com a matemática, que em arquitetura se traduz por dimensões postas em relação, através de modulações, estipulando sistemas de proporção definidos por medidas precisas, foi tema para um importante ensaio de Collin Rowe, em que o autor delineia similitudes entre a maneira de projetar e os respectivos resultados espaciais encontrados nas vilas de Palladio e Corbusier. [ROWE, 1976: 1-27]. Outra exploração desse tema foi realizada por Joubert Lancha [1999], 
na tese em que essas aproximações também se articulam com a arquitetura de Giuseppe Terragni.

Assim, por meio de uma série de pesquisas, Corbusier determina um sistema de medidas, uma série de relações matemáticas, baseadas na seção de ouro aplicada à figura de um homem de braço elevado. Estava criado o Modulor, batizado a partir da contração module (módulo) + seccion d'or (seção de ouro ou áurea). Tal foi o otimismo de Corbusier com sua criação, que motivou a publicação de um livro, em 1950, explicando como havia criado o Modulor, suas teorias e possíveis aplicações: O Modulor: ensaio sobre uma medida harmônica à escala humana, aplicável universalmente a arquitetura e a mecânica [JEANNERET-GRIS, 1950]. Dessa operação, surgem duas séries de medidas que tomariam o lugar dos dois padrões de medida, o métrico e o polegada, chamados de série vermelha e azul. Essas duas séries são séries de Fibonacci, em que cada termo é igual à soma dos dois termos anteriores: 1, 2, 3, 5, 8, 13, 21 e assim sucessivamente. A relação desses números tende ao número de ouro. As duas séries podem ser cruzadas, estabelecendo relações de medidas também na proporção áurea [KRUGER, 1986: 23; BOESIGER, 1998: 86-87]. O objetivo de Corbusier era permitir, através de normas matemáticas, uma cadeia ilimitada de combinações e proporcionalidades que oferecessem possibilidades de criação tão organizada como a linguagem musical.

\section{PENSAR COM OS OLHOS DA MENTE}

Das pretensões de Corbusier, algumas são notáveis e merecem ser re-examinadas, confrontando com a crítica usual. Mais do que conceber a imagem de um homem universal, 
generalizando características particulares (chegou-se a dizer que a altura do Modulor era a altura média do detetive francês), Corbusier pretende instaurar um modelo universal que, unindo e fazendo a conversão entre dois padrões de mensuração, permitisse organizar o espaço em forma, construindo os objetos de uma cultura moderna [JEANNERET-GRIS, 1950: 50-69]. Ao contrário de um simples método, não é mera representação expressiva circunscrita aos limites do código, mas sim raciocínio baseado em relações matemáticas, processo de semiose derivado das qualidades contidas no Modulor como diagrama.

Esse raciocínio contido no Modulor e a sua definição como diagrama, devem ser detalhados. Para Peirce, raciocinar, é forma de conhecer, de produzir conhecimento. Segundo ele há três tipos de raciocínio: indução, dedução e abdução. Dentre os três, a dedução se faz por um processo em que:

"Formamos na imaginação uma certa representação diagramática, isto é, icônica, um esqueleto tanto quanto possível. (...) Se for visual, será geométrico (...) ou algébrico (...). Esse diagrama, que foi construído para representar intuitivamente as mesmas relações abstratas expressas nas premissas, é então observado e uma hipótese sugere que há certa relação entre suas partes (...). Para testar isso, várias experimentações são feitas sobre o diagrama, que se modifica de várias maneiras. Esse procedimento (...) não lida com a experiência em curso, mas com a possibilidade ou não de certas coisas serem imaginadas. (...) Isto se chama raciocínio diagramático." [PEIRCE, 1978, C.P.II: parágrafo 778]

É o tipo de raciocínio utilizado na matemática, que opera construções generalizantes, diagramas, formados de acordo com hipóteses [PEIRCE, 1978, C.P.III: parágrafo 560]. O que 
de fato distingue a matemática não é seu objeto, mas o método, que consiste em analisar tais construções, tais diagramas "trazendo a representação esquemática das relações contidas no problema para os olhos da mente". [PEIRCE, 1978, C.P.III: parágrafo 556]

Esses diagramas são ícones, que por serem hipóteses, representações hipotéticas ou derivarem delas, foram designados por Peirce como hipoícones. Ou seja, o diagrama é um hipoícone que representa as relações das partes de uma coisa por relações análogas às suas próprias partes [PEIRCE, 1978, C.P.II: parágrafo 277]. A força do diagrama está, além da matemática, em ser a base de todo o raciocínio.

"Todo raciocínio elementar, sem exceção, é diagramático. Ou seja, construímos um ícone de nossas hipóteses e as observamos. (...) Não apenas temos que selecionar os aspectos do diagrama que serão pertinentes observar, mas é também de grande importância retornar diversas vezes a certos aspectos. (...) Mas o ponto mais relevante consiste na introdução de abstrações adequadas. Com isso quero dizer que uma tal transformação em nossos diagramas que aquilo que caracteriza um diagrama pode aparecer em outro como coisa". [PEIRCE, 1978, C.P.V: parágrafo 162]

\section{A ANALOGIA DO CORPO COMO HIPÓTESE}

O diagrama é, portanto, um ícone de relações, em que a ligação com seu objeto, ou as possíveis associações com outros objetos, se dá por analogia e similaridade, que pressupõe um raciocínio mais elaborado e criativo [FERARRA, 1993: 172]. E sua natureza é profundamente enraizada nos modos de pensar da matemática, pois está relacionada a hipóteses, experimentações, num processo de descoberta. Assim, o Modulor é um diagrama, pois esse é uma construção 
hipotética, um hipoícone, uma imagem-tese, construída por uma série de relações matemáticas, por analogia às dimensões do corpo humano, que deverão ser testadas, observadas, reexamidas e re-elaboradas, produzindo sempre possíveis, outros diagramas, que poderão apontar para idéias de arquitetura, possíveis projetos, que guardam semelhanças com o diagrama que os originou, que porventura, podem se tornar, nesse outro diagrama, 'coisa', espaço.

Entre diagramar o espaço e expressar o espaço, portanto, há diferenças significativas. Expressar significa enunciar, manifestar terminantemente, de forma decisiva e indubitável, através de um código específico ou de um determinado veículo. Expressar o espaço significa representar através do desenho, de um tipo especial de desenho que, em última instância, é um fim em si, sinônimo do projeto. Perrone [1993: 58-59], diz que "o desenho é um duplo da obra arquitetônica em toda a sua envergadura e complexidade".

Entretanto, o desenho não é o espaço e nem a arquitetura, como chama a atenção Ferrara, ao analisar a maneira de projetar e pensar o espaço do próprio Corbusier:

"Para organizar o espaço, utiliza-se o projeto que se confunde com os elementos que se emprega para aquela organização e com as quais ela é traduzida. (...) Essa tradução faz com que se entenda a linguagem da arquitetura submissa aos veículos expressivos usados, no presente e no passado, para a comunicação das soluções projetivas (...) Entende-se que o espaço é manipulado tecnicamente para adequar-se a uma estabilidade funcional que o submete a um código projetivo absoluto e imutável. (...) Reduzida ao espaço bidimensional, a arquitetura confunde-se com o projeto arquitetônico e o desenho é seu signo incontestável, sua representação". [FERRARA, 2000: 154] 
O pensamento de Corbusier não se limita a essa redução do desenho expressivo sob o código do desenho arquitetônico, mas comporta o desenho como parte do raciocínio do espaço, do pensamento do espaço. Algo mais próximo do desenho como signo que contém a visão de mundo que concebe a arquitetura [PERRONE, 1993: 459], que de forma dinâmica, estabelece relações, testa e experimenta, se transforma no processo de projetar. Essa maneira de utilizar o desenho como meio, como raciocínio e pensamento, é similar ao conceito de diagrama. Diagramar o espaço, portanto, é pensar sobre suas possibilidades como no raciocínio dedutivo, estabelecendo relações, similaridades e analogias, operando por hipóteses, experimentando, e voltando sempre sobre os resultados e até mesmo sobre o próprio processo, diagramaticamente.

\section{A GÊNESE DO ORGANISMO}

Por trás da crítica de generalização ideal sobre a qual se funda o Modulor, se esconde a abstração dos modelos matemáticos. Tanto o padrão métrico quanto o padrão polegadas, são representações matemáticas abstratas, são diagramáticas, ou seja, permitem pensar o espaço. O mérito do Modulor está em transformar as dimensões humanas, independente da referência utilizada, num diagrama que contém informação essencial para a concepção do espaço. $O$ próprio Corbusier afirma que as medidas do Modulor são medidas que contém uma corporalidade:

"As cifras do Modulor são medidas que, em si, contém uma corporalidade; elas são o efeito de uma escolha entre o infinito de valores". [JEANNERET-GRIS, 1950:

60]

Os objetos construídos segundo essas medidas vão fixar os continentes e os prolongamentos do homem. É fundamental assinalar que mais do que a figura humana, Corbusier se 
baseia no corpo, nas relações proporcionais do corpo humano, para diagramar o Modulor.

Esse ponto de partida pressupõe compreender o espaço como resultado de um pensamento diagramático, que advém das percepções da experiência do espaço em si. E isso se dá através do corpo. É através do corpo que se percebe o espaço, é o corpo que informa sobre o espaço. Como diz Alberto PerezGomez:

"A percepção é nossa forma de conhecer primordial e não existe aparte o 'a priori' do corpo e de seu engajamento no mundo. O corpo é o 'locus' de toda a formulação sobre o mundo; não só ocupa o espaço e o tempo, como consiste de espacialidade e temporalidade. $O$ corpo tem uma dimensão. Através do movimento polariza a realidade externa e a torna nosso instrumento de sentido, de significação; esta experiência é, portanto, 'geométrica'." [PEREZ-GOMEZ, 1983: p.3]

Se esta experiência geométrica do corpo permite realizar as formulações sobre o mundo é porque nessa experiência também flui o pensamento criativo, uma experiência analógica, como definida por Valéry [1999: 135]. É desse modo que define um lugar geométrico, lugar com estatuto de espaço para o corpo e para o próprio Corbusier, ao apontar para um outro possível pensar a arquitetura. Como diz Foucault:

"O espaço das analogias é, no fundo, um espaço de irradiação. Por todos os lados, o homem é por ele envolvido; mas esse mesmo homem, inversamente, transmite as semelhanças que recebe do mundo. Ele é o grande fulcro das proporções - o centro onde as relações vêm se apoiar e donde são novamente refletidas." [FOUCAULT, 2002: 31]

Assim como as tecnologias do desenho estão fundadas sobre conjuntos de conhecimentos científicos que se aplicam à 
concepção do projeto do espaço, que informam sua criação, o Modulor está fundado sobre relações matemáticas sofisticadas que traduzem as dimensões do corpo, do humano, em informação fundamental para a criação dos objetos e dos espaços para esse mesmo homem. Corbusier transforma o corpo em informação. Peter Blake [1963: 138] assinala que

"A concepção de regra para Corbusier está intimamente ligada às leis da vida; e o sistema modulor é uma bela expressão do que ele pensa".

O Modulor ultrapassa a simples tradução das dimensões do corpo para escalas de relações numéricas, ordenadas matematicamente, que servem como material para diagramar o espaço, mas também apreende a idéia de organismo, a vida desse corpo, seus elementos essenciais, a idéia de célula e de suas possíveis combinações. Aí, de fato, estão as informações que dão vida ao organismo, como sistema de relações, que vão aparecer nos projetos de Corbusier no pós-guerra. No arranjo dos espaços e suas várias possibilidades formais a figura humana do Modulor é corpo traduzido em números e as possibilidades que apontam, mathesis, e organismo traduzido em sistema de relações, das várias combinações possíveis no momento da criação, gênese.

ORGANISMO E SISTEMA:

A ESTRUTURA COMPLEXA DO TODO DIFÍCIL

À idéia de que a cultura está submetida inexoravelmente a um processo de evolução linear e contínuo, conforme a teoria evolucionista darwiniana, agregou-se a noção de revoluções sucessivas, no mais das vezes descompassadas, que se escondem sob o manto linear evolutivo [KUHN, 2000]. O que se apresenta apenas como desenvolvimento natural, esperado na obra de um arquiteto pode trazer em seu bojo transformações 
fundamentais. A habitação coletiva foi tema de inúmeros projetos de Corbusier desde os anos 20, o que não significa que as unidades de habitação por ele projetadas sejam a evolução correspondente das máquinas de morar. Traços do pensamento anterior reverberam, transitam adiante na contínua revolução de sua obra.

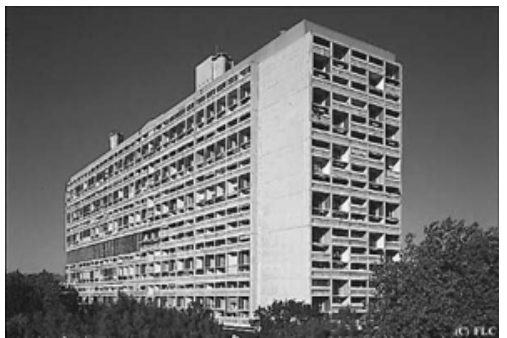

6. Unidade de Habitação de Marselha

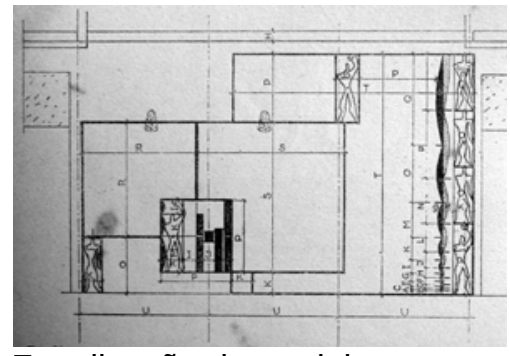

7. aplicação do modulor ao projeto de Marselha: módulos-medida.

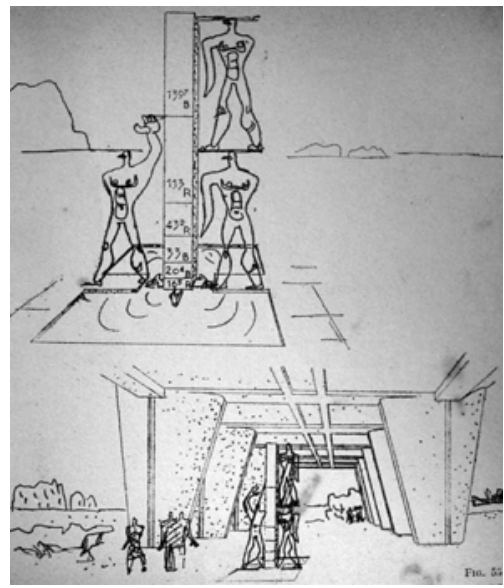

8. representação gráfica da aplicação do Modulor
O Modulor como raciocínio diagramático possibilita essa transição de pensamento e foi materializado de forma emblemática, pela primeira vez, na Unidade de habitação de Marselha (1947-1952). A Unidade de Marselha é um teste indutivo diagramático da máquina de morar que incorpora outras qualidades, revelando o confronto entre o tripé função, estrutura, ordem e a tríade relação, sistema e organização. O projeto obedece a uma ordem racional clara, expressa por sua estrutura funcional, baseada em proporções harmônicas. Todo o conjunto está baseado na concepção de módulo objeto, de standarts repetíveis e componíveis, ao mesmo tempo em que a organização desses elementos é orientada por módulos medida decorrentes do Modulor. O edifício pode ser apreendido e assim explicado por sua gigantesca estrutura que abriga um intrincado sistema de organização.

Projetado a partir de 15 medidas básicas extraídas do Modulor, essa estrutura monumental (uma laje de 135 metros de comprimento sobre pilotis) contém um sistema de organização baseado na relação de diferentes elementos construtivos, que estabelecem sua proporcionalidade a partir das mesmas medidas, num processo de formar por analogia das partes com as partes e do todo com as partes. Os módulosobjeto se relacionam com os módulos-medida numa sintaxe singular, analógica. A unidade de habitação é um todo construído por uma lógica ao mesmo tempo racional e orgânica, 
em que cada parte tem sua função na estrutura definida pelas relações com todo o sistema e com seu próprio modo de se constituir. Como disse o próprio Corbusier, a intenção era fazer a beleza por contraste [JEANNERET-GRIS, 1950: 134-155].

\section{Entre o racional e mecânico e sua contradição não} excludente com o relacional e orgânico, resulta uma obra em que mais do que contabilizar a diversidade heterogênea de suas partes e funções é necessário procurar compreendê-la em sua complexidade [DE FUSCO, 1985: 481-489]. Que está presente em vários aspectos além de sua gênese modular complexa, objeto e medida: no concreto bruto e cru que revela as imperfeições do fazer da obra assim como as marcas da pele mostram as peculiaridades de cada vida humana; na aproximação antropomórfica dos pilotis sob o grande volume com a própria figura do Modulor; no ritmo musical de tempos e contratempos das fachadas que alternam inversões de cheios e vazios, claros e escuros, movimentos para dentro e para fora [JENCKS, 2000]; na mesura da proporção entre suas partes e o todo em confronto com a profusão de suas relações dimensionais variáveis.

A lógica da estrutura auto-portante e independente adquire expressividade através dos brises, cuja função é indispensável para a sobrevivência do organismo e a manutenção do sistema. Por sua vez remetem aos espaços de transição, as varandas e a própria célula habitacional. Apesar da clareza da estrutura e de sua hierarquia dominante, o espaço interno é organizado por combinações de células, um módulo-objeto, que permitem configurar 23 tipos diferentes de habitação, tensionando o interior da estrutura. Todo o invólucro da Unidade pode ser visto como um organismo que tem papel estrutural e funcional ao estabelecer a relação das partes com o

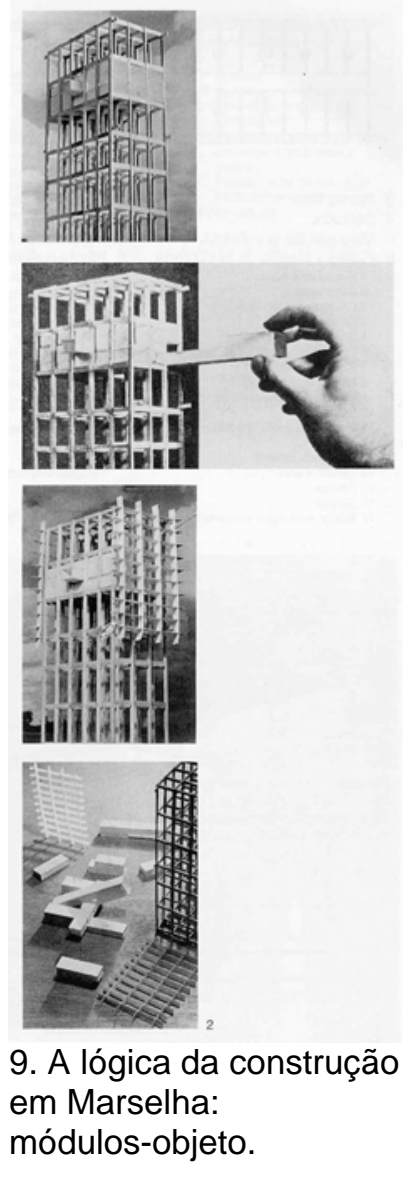

9. A lógica da construção módulos-objeto. 
todo. Enfim, um diagrama relacional formando uma unidade orgânica e complexa.

Como disse Venturi [1995], a arquitetura é um sistema complexo que se constitui por relações ambíguas, e assim não poderia ser representada e compreendida através da obra de um único arquiteto, desvinculado da própria história da disciplina e da cultura em que está inserida. Mas para demonstrar que houve uma passagem, dentro da própria lógica do moderno, em direção a uma outra racionalidade, Corbusier e o Modulor parecem exemplares. O que não exclui a possibilidade de fazer a leitura dessa transitoriedade na obra de outros arquitetos tampouco a necessidade de retornar ao próprio Corbusier em outros projetos.

Assim, outro exemplo significativo é o projeto de Frank Lloyd Wright para o Museu Guggenheim de Nova Iorque (19571959). É sabido que Wright personificou, via Zevi [1945] a possibilidade de revisão e humanização da ordem racionalista e seu programa social. Mas é preciso lembrar que a concepção orgânica da arquitetura foi fenômeno paralelo ao racionalismo e que apesar da descendência distinta, lógica e intuição, comungavam a mesma vontade por estabelecer uma relação harmônica do homem com o ambiente [ARGAN, 2001: 71-78].

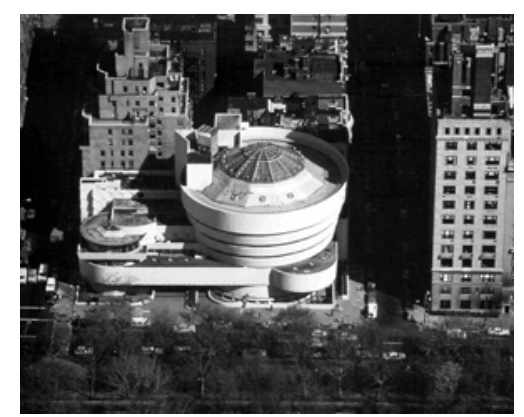

10. Museu Guggenheim, NY, Frank Lloyd Wright.
O museu de Wright, cuja estrutura principal consiste num volume cortado em tira espiralada e contínua, de sentido ascendente, a base menor do que o topo confere forma à imagem de movimento circular excêntrico e para cima. Apesar de excêntrica, a forma espiral também indica um movimento sobre si mesma, para dentro. A relação analógica desse volume maior e do menor, cilíndrico e a lâmina horizontal que os conecta, remetem a uma máquina limpa de engrenagens 
despidas de suas ranhuras e saliências. Um organismo plástico-dinâmico [ARGAN, 1992] em movimento. Do exterior é inevitável ao olhar, aos olhos da mente em fluxo cognitivo, fazer a analogia da forma espiral com o movimento circular e ascendente. Do interior do edifício, a analogia surge entre fruição do espaço e forma da circulação. A obra sugere a relação entre forma e função aproximando e contrapondo, de maneira dinâmica, o movimento do olhar no espaço e o tempo na fruição do percurso.

No interior do museu, a rampa é forma de tira espiralada e centrífuga que ascende visualmente e recorta uma grande abertura de luz no topo, apontando uma possível continuidade do espaço e do movimento. A mesma rampa, desde cima, é função que impele o movimento na direção contrária, indicando o percurso centrípeto descendente. O movimento ascendente da forma é reafirmado e duplicado pela circulação vertical do elevador, a parte mecânica do todo, a idéia de máquina contida dentro organismo. O centro do espaço interno é um grande vazio sobre o qual se pode debruçar da rampa, mas o olhar do usuário é centrifugamente forçado para fora rumo as paredes que servem de suporte para as obras. O espaço é um campo de forças, comportando movimentos em todas as direções, para cima, para baixo, para fora e para dentro, simultâneos e contrários, percurso e olhar.

A estrutura forma um sistema orgânico em que parte e todo, na organização formal que suplanta a funcionalidade, estão em relação na fruição do espaço. O Guggenheim de Wright, comportando a pureza da ordem e a precisão da forma, absorvendo a máquina como imagem e como elemento funcional, representa ao mesmo tempo uma mudança para um modo de concepção espacial que se constrói não por uma

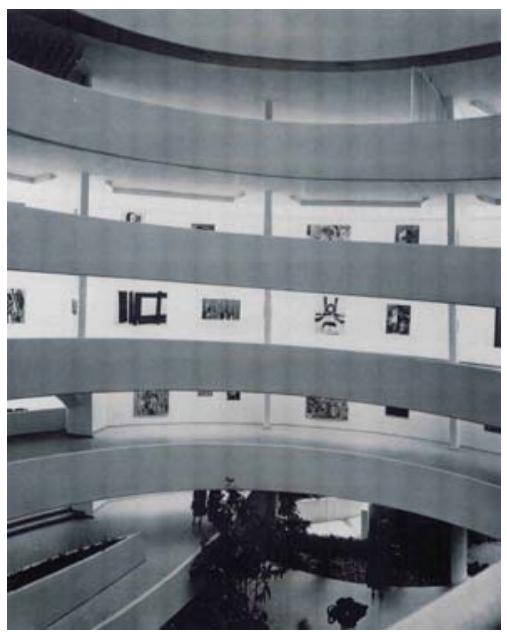

11. A tira espiralada da rampa.

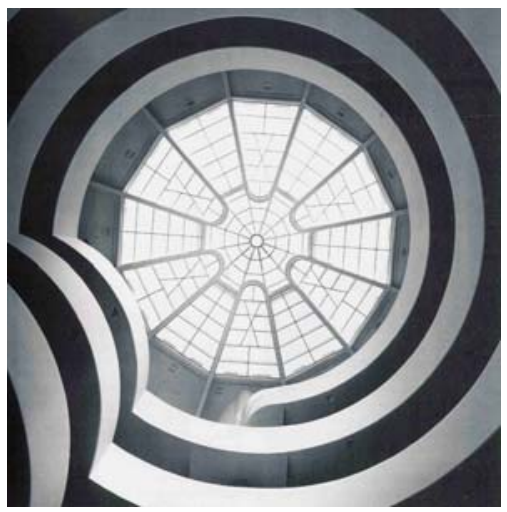

12. Vista da rampa: de baixo para cima. . .

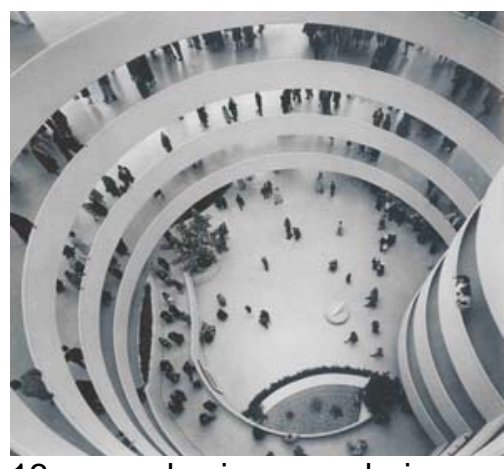

13. ... e de cima para baixo 
lógica, mas por uma analógica. A analogia é justamente a capacidade de combinar coisas e idéias que podem parecer equívocas ou obscuras. Ao contrário da lógica racional e determinista que busca o significado exato, a analogia comporta a multiplicidade de representações e significações. $O$ edifício materializa inúmeras imagens, por vezes contraditórias, que vão do determinismo da ordem e da máquina a indeterminação do campo de forças e do movimento. Essa complexidade suscita, no dizer de Valéry, relações

"entre coisas que a lei de continuidade nos escapa".

[VALÉRY, 1998: 23-24]

Ainda segundo ele, essas

"analogias resultam do fato de que uma impressão pode ser completada de duas ou quatro maneiras diferentes. Uma nuvem, uma terra, um navio, são três maneiras de completar uma certa aparência de objeto que surge no horizonte sobre o mar. O desejo ou a expectativa precipita no espírito um desses nomes". [VALÉRY, 1998: 37]

O que se pode supor, antes de concluir, é que o diagrama, o raciocínio diagramático, afinado com a analogia, permite evoluir o processo associativo em direção aberta, próximo da configuração da racionalidade apoiada no triângulo organização, relação e sistema. Passa-se do pensamento aparentemente linear, que se apoiaria na estrutura matemática do módulo para um pensamento que opera por relações sistêmicas abertas. O que corresponde, segundo Ferrara em sua proposição Por uma semiótica visual do espaço [2002: 94115], a categoria da

"visibilidade, da qual decorre a elaboração reflexiva do dado visual, transformando-o em fluxo cognitivo".

[FERRARA, 2002:101],

em contraposição à visualidade, que corresponderia à constatação passiva do fato visual. Mais adiante ela explica: 
"A construção dessa visibilidade supõe enfrentar o espaço como alteridade desafiadora que exige resposta, não para ser organizado a partir de um programa a priori, mas para ser descoberto e revelado pelo próprio ato projetivo, apoiado em três pilares: a analogia, o diagrama e a experimentação que estabelecem, para a atividade projetiva, as etapas ou elementos básicos do processo de raciocínio que lhe é característico: arquitetar com os olhos da mente (PEIRCE. C.P. 3.556)". [FERRARA, 2002: 107]

Nos anos 40, Corbusier afirmou haver um tipo de espaço resultado de certas qualidades arquitetônicas, que chamou de espaço indizível. Esse espaço, no campo da visibilidade, é o fenômeno acústico no domínio da forma,

"um fenômeno de concordância se apresenta, exato como um a matemática, verdadeira manifestação da acústica plástica". [JEANNERET-GRIS, 1954, 217]

A busca de Corbusier por um sistema de medidas para a criação livre da arquitetura equivalente aos sistemas musicais se convertia em forma acústica. Segundo ele, a orelha deveria ouvir a forma e o olho escutar a música das proporções visuais [JEANNERET-GRIS, 1954, 154; 264-268]. Essa analogia entre som e espaço remete à categoria da visibilidade, exigindo uma reflexão sobre o espaço, que muitas vezes também se torna indizível.

No período do pós-guerra, talvez o exemplo que represente de modo mais radical essa mudança da concepção de um espaço programado em direção a uma concepção que comporta o ato projetivo como relacional e sistêmico seja a capela de Ronchamp (1950). Suas linhas curvas e as formas arredondadas e inexatas, e as diversas referências contidas na obra, declaradas ou não pelo arquiteto, inspiraram variadas interpretações. Na época em que fez o projeto, meados dos

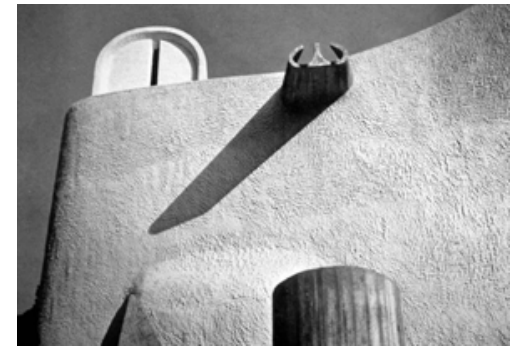

14. Ronchamp.

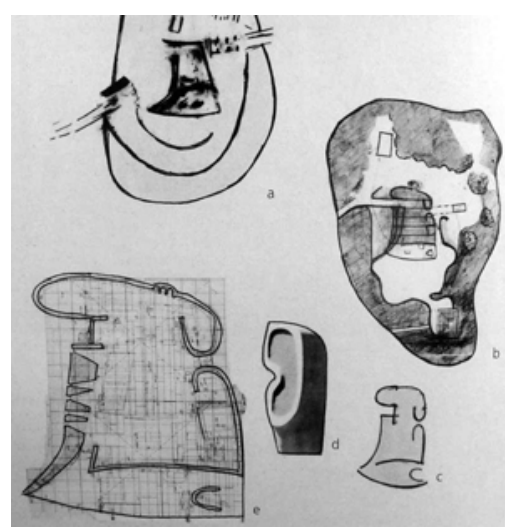

15. As comparações de Jencks. 


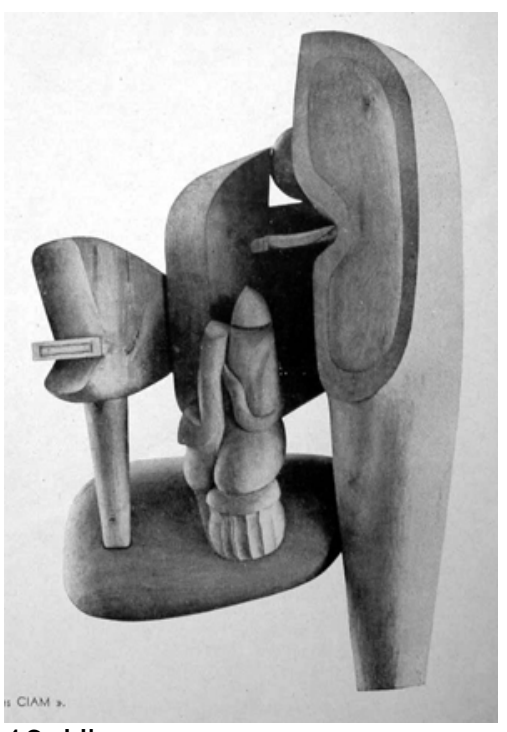

16. Ubu

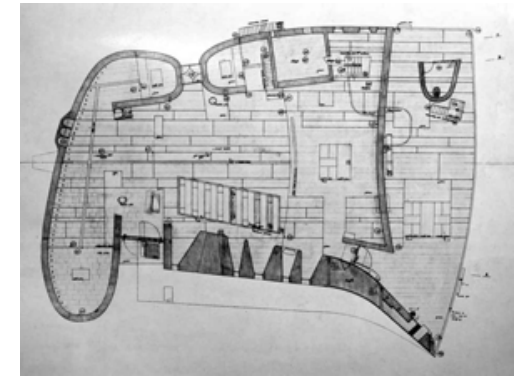

17. Planta de Ronchamp

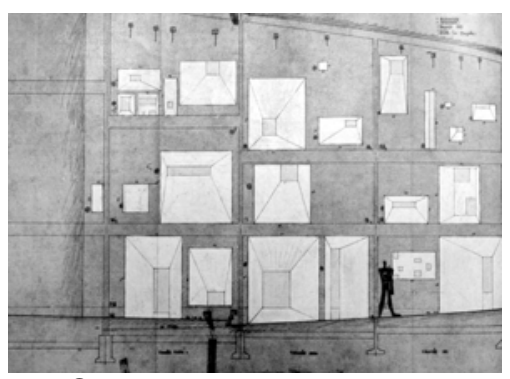

18. O modulor em Ronchamp. anos 40, Corbusier tinha em sua prancheta um casco de caranguejo, que segundo ele, tomou forma na cobertura [LE CORBUSIER, 1957: 89].

Jencks [2000: 263-267], detectou formas similares àquelas que aparecem na capela em experiências precedentes do arquiteto. Na mesma época, os anos 40 , Corbusier fez uma série de obras plásticas, quadros e esculturas que batizou de Ubus, fazendo referência a obra Ubu Rei de Alfred Jarry. Eram curvas e bolhas, volumes abstratos, e biomórficos, colocados em relações desordenadas, quebrando o purismo de suas convicções formais. Essa forma que se assemelha a uma orelha, torna-se dominante em Ronchamp. Jencks [2000: 267] diz que apenas essa analogia do formato da orelha com o fenômeno acústico seria suficiente para considerar a obra como precursora do pós-moderno.

A capela de Ronchamp é um diagrama relacional de formas organizadas por uma geometria como fenômeno visual, que contém regras que abarcam harmonia e poesia [JEANNERET-GRIS, 1954: 221]. À analogia entre as formas que constroem todo o objeto, curvas e suas variações, combinações que fazem coexistir partes de umas nas outras [VALÉRY, 1998], soma-se outra dentro da obra do arquiteto, no decorrer de seu percurso plástico, que indica uma volta sobre si mesmo, sobre o pensamento em si, um retorno diagramático. Entretanto, não é um retorno que leva ao mesmo lugar, mas inaugura uma novidade, aponta uma mudança na trajetória do arquiteto. A base matemática do Modulor, a malha ortogonal de origem desaparece em meio a sucessivas distorções variadas. Corbusier desafia a quem queira determinar as dimensões do espaço sem medir [LE CORBUSIER, 1957: 118]. 
O arquiteto que amava as máquinas e idealizava as máquinas de morar, declarou aquilo que poderia ser a divisa de um movimento:

"A lição da máquina está nas relações de causa e efeito.

Pureza, economia, o encontro da sabedoria". [LE

CORBUSIER, 1987: 115]

Depois da guerra e de sua alargada experiência, dizia algo que poderia representar um divisor, uma alteração na direção do movimento:

"Nós aprendemos que tudo está arranjado de acordo com princípios concernentes ao todo; que todo organismo é um tipo de elo numa cadeia de variantes em torno de um eixo entre dois pólos, variantes que respondendo a um único fator estabelecem uma série; um sistema coerente varia de acordo com incontáveis possibilidades de combinações". [LE CORBUSIER, 1987: 175-177]

\section{A CONTRADIÇÃO DA COMPLEXIDADE}

E agora voltando a Venturi, se pode perceber que, se por um lado Complexidade e contradição abre várias frentes para pensar a essência da arquitetura e aponta para a pluralidade de possibilidades, então confinadas aos moldes do moderno, por outro sua teoria encontra um débil paralelo até nas suas próprias obras. Segundo ele próprio, depois da publicação de Complexidade e Contradição, compreenderam (ele e sua equipe) que poucos de seus projetos eram complexos e contraditórios, em suas qualidades puramente arquitetônicas:

"Não havíamos sabido introduzir em nossos edifícios elementos de duplo funcionamento ou atrofiados, distorções circunstanciais, artifícios pragmáticos, exceções memoráveis, diagonais excepcionais, coisas em coisas, complicações amontoadas ou contidas, espaços residuais, espaços redundantes, ambigüidades, inflexões, dualidades, todos difíceis ou fenômenos de tanto-como.

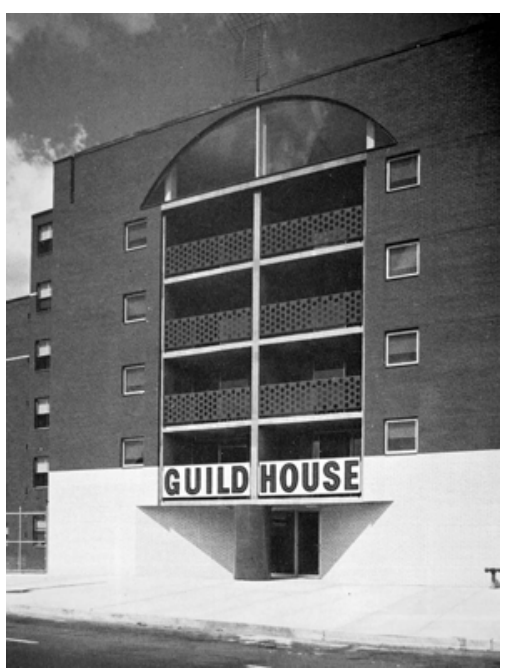

19. Guild House

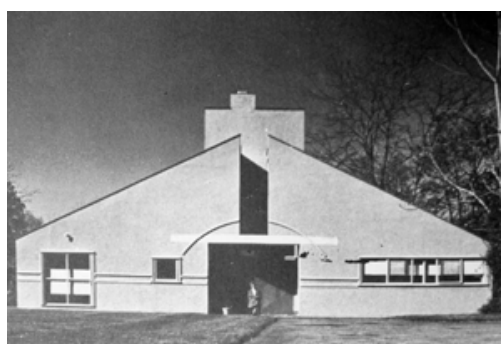

20. Residência em Chestnut Hill.

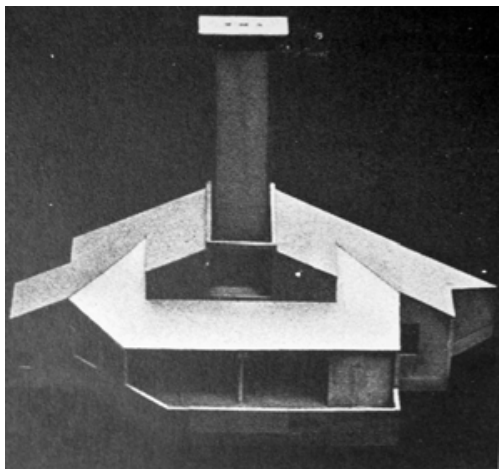

21. Projeto para casa de praia. 
Em nossa obra escasseava a inclusão, a incoerência, o compromisso, a acomodação, a adaptação, a supercontiguidade, a equivalência, o foco múltiplo, a justaposição ou bom e mal espaço". [VENTURI, 1978: 159]

A justificativa era de que não haviam tido a oportunidade, não haviam recebido encomendas de projetos em que pudessem colocar em prática aquilo que tanto haviam saboreado em pensamento, como teoria. De fato, sua arquitetura mais radical seria em defesa da decoração, da máxima funcionalidade dos galpões de estrutura simples e limpa, de espaços vazios, funcionando como suporte extremo,

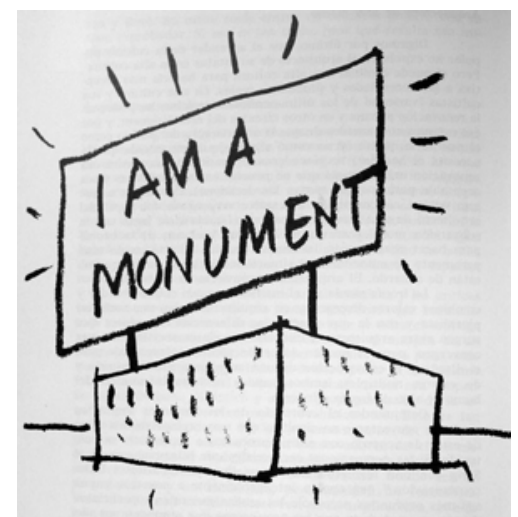

22. A arquitetura comunicativa de Venturi. fachada para a comunicação e a propaganda.

Ao invés de restringir a invenção de Corbusier como uma representação tardia dos ideais modernistas das vanguardas das primeiras décadas do século, é possível compreendê-la em sintonia com as transformações que se iniciam após a segunda guerra mundial, principalmente nos campos da ciência e das tecnologias de informação. Transformações que vão desembocar, nos anos 90 e início do século XXI, em outras concepções do espaço, do objeto e do próprio humano. 
capítulo 2

\section{do pensamento à linguagem}

ou da arquitetura como estrutura à arquitetura como sistema 


\section{O DESENHO COMO PROCESSO SINTÉTICO}

A crescente complexidade dos problemas com que se defronta a arquitetura é proporcional à crescente complexidade da informação confrontada por um alto grau de entropia desorganizadora. Frente a essa mudança acelerada é preciso compreender o processo de criação do projeto através da proposição de um método analítico que permita interpretar as questões e os problemas de projeto na sua consecução especulativa, no processo de projetar e ao mesmo tempo tentar, através dele, alcançar a melhor solução projetual. As afirmações acima resumem as linhas gerais da tese de Christopher Alexander em seu Ensaio sobre a síntese da forma [1969], sua tese de doutorado, foi publicada originalmente em 1966, mesmo ano da publicação de Complexidade $e$ contradição [1995] de Venturi. Nas primeiras linhas da introdução, ele define sua principal preocupação:

"Estas notas se referem ao processo de desenho, ou seja, o processo de invenção de coisas físicas que exibem uma nova ordem física, uma organização e forma novas, em resposta à função". [ALEXANDER, 1969: 9]

Que atualmente o primeiro, que no título original em inglês traz a humilde designação de notas - Notes on the synthesis of form, raramente seja lembrado ou mencionado enquanto que o segundo seja considerado como um tratado, talvez o mais importante escrito sobre a criação e a produção da arquitetura desde Por uma arquitetura [2002] de Corbusier, como diz Scully na introdução do livro de Venturi, é sintomático. Os dois partem da mesma constatação da complexidade do fato arquitetônico e da mesma estratégia de decomposição do objeto arquitetônico em seus elementos. Entretanto, Venturi elabora sua teoria sobre a revisão do passado, perfazendo uma análise sincrônica de obras de arquitetura para tecer uma crítica 
ao racionalismo e ao funcionalismo que, reducionistas, impedem a inclusão da contradição e da complexidade em suas realizações. Ao passo que Alexander formaliza suas idéias confrontando a atualidade, questionando a continuidade do pensamento moderno cristalizado que se nega a reconhecer $\mathrm{e}$ a enfrentar a emergência de uma nova racionalidade que traz consigo a possibilidade de novas formas de projetar.

A síntese da forma é uma crítica à resposta confortável dos arquitetos frente às transformações de sua época sempre procurando uma zona de segurança. Dessa maneira, o Renascimento resgata a linguagem clássica para se apoiar sobre uma regra de correção que os desobrigava das responsabilidades de responder diretamente aos problemas da época ao impor a cópia exata. Aos arquitetos se faz necessário enfrentar as mudanças que conformam os problemas da atualidade, assim como fizeram Gropius e Corbusier com a industrialização e a máquina. A época atual, segundo Alexander, solicita compreender os processos sistêmicos, reconhecendo as forças que incidem sobre a expansão da capacidade intelectual e inventiva [ALEXANDER, 1969: 15-18].

Alexander parte do princípio de que o objetivo final de todo projeto é a forma e que esta se define pela relação com o contexto. A forma é um diagrama de forças das irregularidades [ALEXANDER, 1969: 21]. Assim, supõe que é possível atingir a definição da forma ou do projeto, do objeto ou do espaço, através de formalizações lógico-matemáticas que contemplem tal relação. Sua tese subentende a matemática como ciência que se ocupa dos problemas de ordem e das relações e que a lógica seria uma ferramenta para tomar as informações da realidade e representá-las por abstrações.

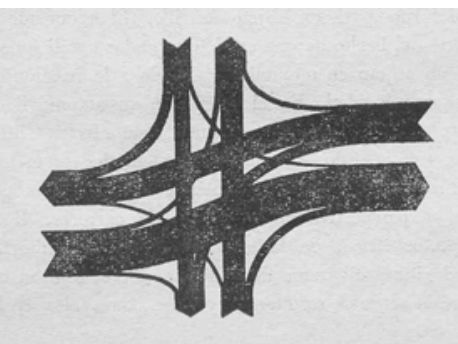

23. Diagrama de forças de Alexander. 


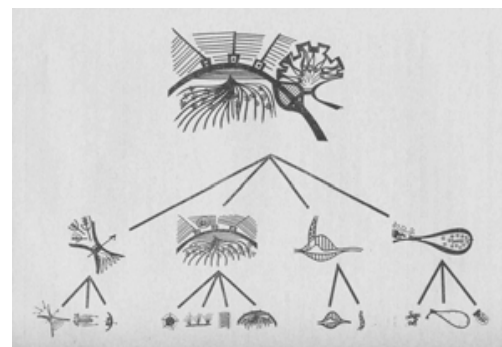

24. Lógica dos conjuntos

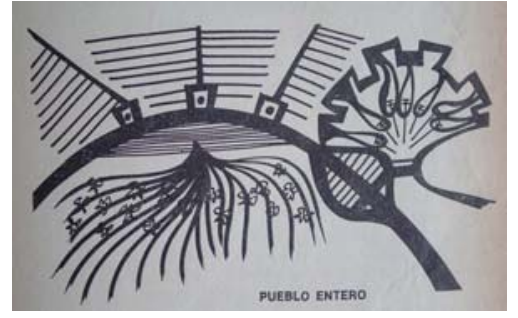

25. Programa em diagrama

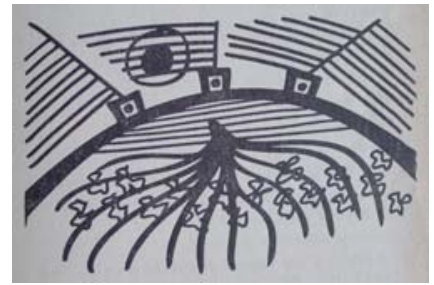

D3
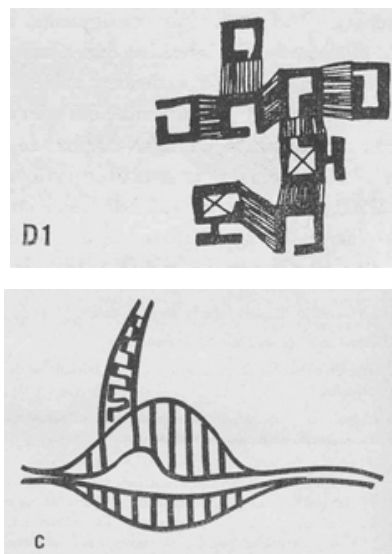

26 a 29. Diagramas de sistemas e sub-sistemas
O programa moderno, definidor do caráter funcional do espaço segundo necessidades específicas se transmuta em programa de desenho, 'processo de invenção', que contém as instruções para resolver o problema colocado para um projeto específico. O problema bem formulado que traz todos os dados para se atingir a melhor solução [ARGAN, 2002: 265-266] se renova na decomposição precisa de elementos traduzidos em informação simbólica e corresponde a uma equação corretamente formalizada. Esse programa é, a um só tempo, processo analítico que pretende conter o conjunto de variáveis que condicionam o projeto e processo sintético, a concepção do projeto, a síntese da forma [ALEXANDER, 1969: 75-84].

\section{A formulação do programa de desenho de Alexander} traduz o pensamento diagramático das imagens mentais, os croquis, em equações, diagramas matemáticos, organizadas num conjunto ordenado. Na consecução do projeto, na síntese da forma, o conjunto deriva subsistemas cada vez mais complexos à medida que se aproximam da melhor resposta ao problema de partida. O resultado é o que ele chama de diagrama construtivo, uma hipótese que representa aspectos da organização do espaço em relação à qualidade formal, constituindo um conjunto de forças relacional, a forma. $\mathrm{O}$ conjunto é sempre provisório, pois as relações entre contexto, forma e experimentação geram a tensão que provoca alterações à medida em que se desenrola a atividade especulativa, num processo de tentativa, erro e acerto, em busca da síntese da forma. É preciso conhecer esse processo, dominá-lo conscientemente. [ALEXANDER, 1969: 85-94]. 
A teoria dos conjuntos sobre a qual trabalha Alexander encontra-se na corrente da formalização e matematização da lógica que desembocou na lógica de Boole e postula a transformação das proposições em equações. A lógica de Boole consiste na determinação de classes, um conjunto de objetos com qualidades comuns em correlação constante de predicados, as qualidades que definem os objetos da classe. $O$ predicado é uma relação entre duas variáveis, chamada função. Daí a formulação evolui para a relação entre dois ou mais conjuntos, donde prevalece a relação binária que abre caminho para a linguagem simbólica dos algoritmos. Esses podem ser definidos como instruções em linguagem matemática [CHAUÍ, 2002: 179-204].

É importante notar que a matemática sempre esteve presente na ideação do projeto arquitetônico, nos processos de concepção da forma e na construção do espaço, do Renascimento com as representações calculadas da perspectiva e nas relações harmônicas dos sistemas proporcionais postos em ordens, passando pelos séculos XVII e XVIII e a transformação da geometria como pensamento simbólico e transcendente para sua utilização como instrumento tecnológico positivista [PEREZ-GOMEZ, 1980: 159-247; 389468]. Entretanto, segundo Alberto Perez-Gomez, o racionalismo tende a despir essa presença de qualquer significado transcendente, reduzindo-a a mera função, no sentido matemático.

Essa funcionalização da arquitetura evolui desde o Renascimento e vai se configurando até o século XIX, com Durand (1760-1834). Em seu Compêndio de lições de 


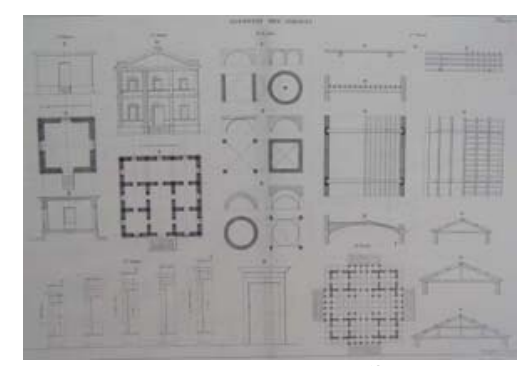

30. Durand: combinações. . .

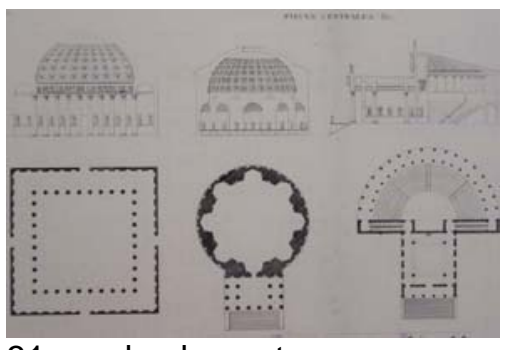

31. . . de elementos:

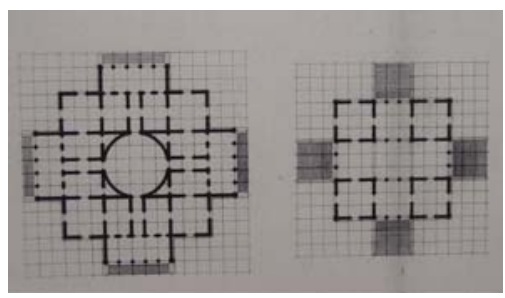

32. funcionalização do projeto. arquitetura, manual de suas aulas na Escola Politécnica de Paris, publicado em 1805, Jean-Nicolas-Louis Durand catalogava os elementos que compunham os edifícios, segundo os materiais adequados e segundo a forma e a proporção necessária. Também indicava como esses elementos deveriam ser combinados entre si, formando as partes do edifício e por fim recomendava as normas para combinar as partes e compor o conjunto do edifício.

Assim, tanto o processo de criação como a arquitetura, estavam reduzidos a combinações formais auto-referentes e sua concepção e representação se apoiavam na geometria descritiva de Monge, simplificando a expressão ao bidimensional e ao traço nítido da linha delgada e precisa. Perez-Gomez reputa a Durand as bases da arquitetura da revolução industrial e conseqüentemente das obras de vanguarda concebidas nos primeiros dois decênios do século XX [PEREZ-GOMEZ, 1980: 429-442].

"A suposição de que a arquitetura pode derivar seu significado a partir do funcionalismo, de jogos de combinação formal, de coerência ou racionalidade, do uso de tipos como estrutura generativa marca o desenvolvimento da arquitetura ocidental ao longo dos últimos dois séculos. Essa suposição implica na funcionalização ou algebrização da teoria da arquitetura como um todo". [PEREZ-GOMEZ, 1983: 4]

As bases matemáticas do programa de Alexander para a concepção do projeto podem aparentar uma contradição frente à sua própria hipótese do diagrama. É necessário lembrar que o diagrama na definição de Peirce surge do raciocínio matemático que configura hipóteses a partir da relação entre partes, entre partes e todo. Esse movimento em direção a numerização do pensamento através da elaboração de algoritmos remete a computação, a informática e ao processamento digital da 
informação e vai formar um todo sistêmico com os processos analógicos, com a criação analógica, com o pensamento diagramático. Essa contradição é parte integrante dessa complexidade e Alexander parece ter clareza quanto a arquitetura ser um sistema de relações dinâmicas, contínuas e complexas. Essa base relacional se instala entre a concepção e a construção, entre processo analítico e processo gerador [ALEXANDER, 1972].

\section{A GÊNESE DA ESTRUTURA NO CERNE DO SISTEMA}

No bojo do desejo de ordem matemática do moderno, na sua determinação funcional expressa na síntese estrutural, também está a negação de complexidades emergentes. No sentido de controlar a manifestação das complexidades inerentes à evolução histórica da ciência e da cultura é que o moderno apela para a lógica determinista e linear. O plano teleológico, o movimento em direção a um objetivo especificado garante o impulso racional para o progresso do projeto moderno. A máquina, a linha de montagem, os standarts, o programa e as formas puras da arquitetura são as respostas mais elaboradas para o processo entrópico da própria arquitetura enquanto sistema. Fugindo à essência sistêmica, brotou a estrutura que dominou a racionalidade arquitetônica moderna. Porém, essa racionalidade estruturada contém o germe do pensamento sistêmico.

No decorrer do século $X X$, os dois conceitos estrutura e sistema, receberam conotações diferentes e abordagens diversas, no mais das vezes tornando-se difícil defini-los, sem confundi-los. Dependendo do campo do conhecimento e do período em que se aplicam, as definições de estrutura incluem 
o termo sistema em sua explicação, ao mesmo tempo em que para compreensão de sistema recorre-se à noção de estrutura.

Pode-se ilustrar a confusão partindo da lingüística de Saussure e as interpretações e desenvolvimentos posteriores à publicação póstuma de seu Curso de Lingüística Geral em 1916 [SAUSSURE, 1970]. Se a análise do Curso de Saussure permite dizer que ele é estruturalista antes do termo, uma vez que não o concebe, é também lícito supor que o é em relação ao pensamento sistêmico. Sua definição de língua como: "sistema de signos onde o essencial é a união do som e do sentido" [SAUSSURE, 1970: 23], pode ser desenvolvida como sistema de sinais em que as partes devem ser consideradas em sua solidariedade sincrônica. A língua é, sobretudo, forma e suas unidades só adquirem sentido ao entrarem em relação e dessas relações deriva o conteúdo. O essencial para Saussure é a idéia de sistema. De certo modo é contraditório que seja considerado e tomado como precursor do estruturalismo sem ser precursor do uso do termo estrutura [BENVENISTE, 1971: 23-31].

Procurando sintetizar a definição de Saussure, pode-se dizer que a língua é um instrumento de pensamento que articula som e sentido, abarcando as dimensões individual e social, configurando um sistema estabelecido e em constante evolução, mantendo relação intrínseca com outros campos da ciência [SAUSSURE, 1970: 15-25]. Em outras palavras, a língua é um sistema relacional rigorosamente organizado em unidades precisas e combináveis em grande variedade e diversidade. Essa complexidade exige estabelecer o diálogo entre os eixos de simultaneidade e sucessão [SAUSSURE, 1970: 95-96; 142-147]. Segundo Piaget, a língua para Saussure é um sistema sincrônico e relacional que opera por distinções e oposições [PIAGET, 1974: 62-63]. 
Como mostra Roger Bastide, o termo estrutura faz parte do vocabulário científico e se aplica a diferentes usos de acordo com cada época. Assim, na origem latina do verbo struere, construir, a derivação structura designa o modo como está construído o edifício. A partir dessa raiz, o termo é adotado para indicar o conjunto ou as partes do conjunto ou ainda a relação dessas partes entre si. Essa acepção expande-se por analogia, ao estudo do homem, do seu corpo e de suas obras. O termo é aplicado em sociologia, em economia, em psicologia e em matemática. Surgem derivados do termo como macro e micro, infra e super, a designação de processos como reestruturação e as dificuldades em distinguir estrutura de sistema, forma, modelo e organização, palavras que adquirem significados diferentes conforme as circunstâncias de tempo e lugar [BASTIDE, 1971: 1-9].

De fato, as várias definições de estrutura se aproximam da definição de Saussure de língua como sistema. E a noção de estrutura usa com freqüência o termo sistema como parte de sua explicação. Na psicologia da Gestalt, a estrutura é um todo constituído de fenômenos solidários interdependentes, definidos pela relação entre si. Em matemática, na teoria dos modelos, a estrutura é um sistema bem especificado de relações que descrevem o fenômeno. No Círculo lingüístico de Praga, estrutura designa uma relação dentro do sistema, que pode ser caracterizado por específicas relações entre partes que traçam o esquema da estrutura [BASTIDE, 1971: 1-9].

\section{ESTRUTURA COMO SISTEMA EM TRANSFORMAÇÃO}

Com o passar dos anos e com o alargamento da adoção da idéia de estrutura pelas várias ciências, o sentido da palavra evolui até o adjetivo estrutural que por sua vez leva ao 
estruturalismo como forma de pensamento. Quando o Estruturalismo toma a lingüística de Saussure como referência epistemológica e metodológica, ao que parece, baseia-se no corte sincrônico que permite suspender o objeto do contínuo do tempo sem isolá-lo de seu contexto e na possibilidade de enxergá-lo como totalidade na interdependência de suas partes. Essa abordagem possibilitaria comparar e aproximar diferenças e, nessas relações e combinações, detectar tanto as invariâncias como as transformações que estabelecem as diversas variantes. Os resultados de análises dessa natureza podem ser simplificados em modelos abstratos, reproduzíveis e aplicáveis a diversos campos de estudo.

Para o estruturalismo, a estrutura, idealmente, se basta a si própria e se auto-explica, não necessitando recorrer a recursos estranhos à sua natureza para ser apreendida. Segundo Piaget, que procura circunscrever as muitas acepções do estruturalismo segundo cada ciência, a estrutura é um sistema de transformações que comporta leis enquanto sistema e compreende os caracteres de totalidade, de transformação e de auto-regulação [PIAGET, 1974: 8-9]. Essa definição demonstra que estrutura e estruturalismo sofreram uma distensão para poder agasalhar sob seu manto as mais diversas áreas.

É importante frisar que a ciência que pretende utilizar a estrutura para explicar o mundo contém em sua gênese a idéia de sistema. Para o seu mais proeminente representante, Claude Lévi-Strauss, que se confunde com o próprio estruturalismo, a estrutura é o próprio conteúdo. A forma e o conteúdo perfazem um todo único e indivisível e as estruturas do conteúdo instituem uma única e possível relação formal [FERRARA, 1981: 6]. Para Lévi-Strauss, a estrutura deve 
atender a duas condições: primeiro, deve ser uma relação regida por uma coesão interna e, segundo, essa coesão deve revelar-se no estudo de suas transformações que permitirão encontrar propriedades similares em estruturas diferentes na aparência [LIMA, 1968]. Assim, a estrutura é o conjunto de relações latente no objeto, ou de relações possíveis entre objetos distintos. A relação está latente nos objetos, pois se baseia em modelos abstratos.

Aqui se encontra a distinção do conceito de sistema na concepção de estrutura. Como para Lévi-Strauss a estrutura é o conjunto de relações latente nos objetos, todas as possibilidades dessas relações podem ser reduzidas a estruturas mentais, abstrações, modelos, pois são nada mais do que modalidades temporais de leis universais [BASTIDE, 1971: 8-9]. O modelo, para ele, guarda as propriedades que caracterizam a experiência, mas difere dela por ser manipulável enquanto dado [LIMA, 1968: 58]. Lévi-Strauss construiu seus modelos estruturais baseando-se diretamente na álgebra, especialmente na teoria dos conjuntos de Boole, a álgebra booleana, por suas propriedades relacionais e suas possibilidades de transformação [PIAGET, 1974: 18-19; LÉVISTRAUSS, 1984: 199].

Assim, o estruturalismo permite definir estrutura como conjunto total de transformações auto-reguladas, poder-se-ia supor que o organismo é então o protótipo da estrutura, que conhecido a fundo, forneceria a chave do estruturalismo [PIAGET, 1974: 39]. Porém, a racionalidade que constrói o modelo estrutural como se contemplasse a organicidade de um sistema, se distingue do organismo enquanto concepção e, portanto, se distingue de organização, uma vez que esta é a constituição real do organismo [BASTIDE, 1971: 9]. 
Essa longa digressão necessária por certo não esclarece a origem de uma nova racionalidade no decurso da evolução da razão vigente. Também não explica como o estrutural contém o sistêmico e o engendra. Mas ressalta a latência de um na essência do outro, assenta e diferencia os principais termos, aborda os conceitos fundamentais que constituem essa mudança. E, sobretudo, procura demonstrar que a razão estruturada conforma esse modelo se reduz, mesmo admitindo transformações à essência estática de uma estrutura. Agora é possível investigar as possíveis raízes do sistêmico como conceito constituinte de uma nova racionalidade.

\section{AS RAÍZES DO PENSAMENTO SISTÊMICO}

Ao procurar circunscrever o conceito de sistema que está na fundação de uma racionalidade que se apóia na dinâmica evolutiva da razão, emergem outros conceitos antes submersos na estaticidade da estrutura. Como aponta Edgar Morin no primeiro volume de seu Método [2002], o conceito de sistema já aparecia em Galileu e não pode ser estudado até a metade do século XX devido ao predomínio de um pensamento isolante e dissociativo. O sistema como estrutura adere a cada matéria e disciplina e não permite vislumbrar possíveis diferenças de natureza [MORIN, 2002: 127-132]. Morin encontra em Saussure o que considera como a definição mais clara e abrangente de sistema, pois faz surgir os conceitos de organização e relação:

"Sistema é uma totalidade organizada feita de elementos solidários só podendo ser definidos uns em relação aos outros em função de seu lugar nessa totalidade". [MORIN, 2002: 131]

Contudo, é em outra obra que Morin traça o que se pode considerar como possível diagrama matriz do conceito de sistêmico, do pensamento sistêmico, ou do sistêmico como 
pressuposto e chave para a compreensão do mundo, que passa a emergir a partir da segunda metade do século $X X . \mathrm{Na}$ procura por decifrar a inexorável evolução, que a abaladora teoria de Darwin despe das vestes do caráter teleológico, [KUHN, 2000: 214-215], Morin desenha O enigma do homem [1979] como permanente movimento espiral entre a natureza e a compreensão de sua gênese e a invenção da cultura e sua constante atualização.

Assim, com o fim da separação entre química, física e biologia torna-se possível perceber que a matéria é constituída por elementos físico-químicos. Esse movimento possibilita transformar a noção de vida e a compreensão da gênese do homem como organismo vivo. Está aberto o caminho para o desenvolvimento da biologia molecular e para a descoberta do código genético, que permitem definir a matéria viva como sistema. A relação da biologia com a física e a química promove uma reconciliação com as formas de organização metabiológicas, como a máquina e a sociedade [MORIN, 1979: 2-28].

Essa abertura da biologia a faz recorrer a outras teorias como a cibernética de Wiener e a teoria da informação de Shannon, na busca por explicar o jogo de combinações e interações baseado em regras estatisticamente improváveis e inerentes a organização dos sistemas vivos. Passa a fazer parte do vocabulário biológico conceitos de caráter cibernético como informação, código, programa e organização. Torna-se possível aplicar a idéia de máquina à unidade fundamental da vida, uma vez que a célula se aproxima da máquina controlada pela informação, permitindo recolocar o segundo princípio da termodinâmica como essencial à organização viva e diferenciador da organização artificial. 
Na teoria dos automatas, Von Neumann afirma que a organização artificial da máquina é degenerativa, qualquer desordem pode alterar o sistema sem que se possa recuperálo, ao passo que para a organização viva, o acaso e a indeterminação, o aumento da desordem, são fatores de organização, embora mais complexa. Para o organismo, a ordem informacional que se forma no tempo contradiz o princípio de desordem que se difunde. O sistema admite a relação contraditória da ordem com a desordem, num processo de reorganização permanente em que a entropia aumenta a sua complexidade.

Paralela e simultaneamente à compreensão da face biológica, a outra parte dessa organização sistêmica e relacional que abarca a biologia e a cultura como dois aspectos relacionados e interferentes, está na gênese social do homem. A sociedade, a organização social se fundam na contradição entre autonomia e dependência do homem com o ambiente. Configura-se um eco-sistema como totalidade auto-organizada, constituído por associações, conflitos, hierarquias e solidariedades. O ecossistema é co-organizador do ser vivo que o habita, alimentando-o de informação, e vice-versa. Assim, um sistema é co-organizador de outro sistema a ele integrado, constituindo uma relação calcada na diversidade de relações contraditórias, porém possíveis de integração. A sociedade como sistema, se mantém emancipada e autônoma na relação de dependência com o ambiente [MORIN, 1979: 69-84].

Esse confronto sistêmico, complexo e relacional entre sistemas, entre homem e ambiente, entre sociedade e ecossistema, exige a necessária elaboração de um conjunto de regras de organização e de modelos de comportamento que 
devem ser transmitidos, ensinados, apreendidos e reproduzidos para poder perpetuar-se e, ao mesmo tempo, perpetuar a complexidade social. A cultura é, assim, um capital organizacional e uma matriz informacional de caráter dinâmico, num movimento entrópico com outros sistemas [MORIN, 1979: 85-93].

A desordem resultante de um processo entrópico é ambígua. Pode ser constituinte da ordem, mas, por outro lado, pode permanecer como desordem, ameaça de desintegração. A ameaça mantida pela desordem é o que força a reorganização permanente geradora de complexidade. A complexidade reside na contradição da desordem que induz à organização. A contradição é condição da complexidade e esse par é inerente à organização como sistema relacional [MORIN, 1979: 47].

Jencks [1997] recomenda uma série de critérios para a arquitetura que sofre a influência dessa tríade organização, sistema e relação e emerge das ciências que tratam da complexidade. Entre eles, sugere que a arquitetura olhe para as ciências da nova racionalidade no sentido de reencontrar a transcendência por elas revelada. A questão sobre a natureza da linguagem dessa arquitetura que compreende a desordem como contradição necessária para as soluções de organização do espaço, permanece em debate [JENCKS, 1997: 167-169; 43-46]. Entretanto, Julio Plaza [1987] infere, a partir de Valéry, que é a complexidade da linguagem que propicia alcançar novas possibilidades de invenção estética. A desordem é condição dos processos criativos, como ressalta Plaza ao citar Paul Valéry:

"A desordem é essencial à criação enquanto essa se define por uma certa ordem". [PLAZA, 1987: 43] 


\section{A ESTRUTURA RELACIONAL E SISTÊMICA DA ORGANIZAÇÃO}

No âmago da relação umbilical entre os conceitos de sistema e estrutura e das formas de pensamento decorrentes residem seus elementos diferenciadores. A cultura que agrega valores capitais para o estabelecimento da organização, que se caracteriza como informação criadora e reprodutora, pressupõe o movimento dinâmico e indeterminado do acaso, exigindo uma postura diferente para a produção do conhecimento, da ciência e da arte.

Porém, para o Moderno, a evolução do conhecimento exige que a informação seja cada vez mais apurada, qualidade que reside na invariância. Há um deslocamento do par clássico coisas e suas propriedades para o par, moderno, estruturas e suas funções. A coisa, o objeto que não varia, é estrutura e a propriedade que permanece inalterada torna-se função. $O$ conhecimento e sua produção estariam, segundo essa concepção moderna, na articulação de estruturas e funções invariantes que, apesar de calcada no desejo de absorver em si o movimento, ainda precisa se basear em modelos abstratos, ou seja, estruturas estáticas [BENSE, 1975: 165-167]. Seria possível supor que o conhecimento passa a ser produzido mesmo e apesar das imprecisões da informação e das ambigüidades decorrentes e exatamente nesse aspecto encontra suas qualidades. O conhecimento e sua produção superam a articulação que remete à inalterabilidade da estrutura, em direção a organização que contém em si a idéia de variação e movimento. Um novo deslocamento leva ao par sistema e suas relações e seu caráter está na sua dinamicidade constituinte. 
Sob a malha conceitual do estruturalismo, articula-se o par antinômico e dicotômico forma e conteúdo que, para LeviStrauss é traduzido como todo único da estrutura, o próprio conteúdo. Contudo, no deslocamento evolutivo dos conceitos, essa dinâmica que mistura funções e relações, que confunde estrutura e sistema, serve de germinação para outros conceitos frutos da modernidade que procura sempre pelo novo. Assim, do interior do moderno, de suas estruturas mais específicas, desponta o impulso de superação da dualidade estática e funcionalista propondo a compreensão da obra como todo orgânico fruto de específicos procedimentos sobre o material e perfaz seu significado na dinâmica relacional.

Já é bastante conhecida e debatida especialmente nos meandros da literatura, a polêmica entre Levi-Strauss e Vladimir Propp, que opôs estruturalismo e formalismo. O estruturalista francês imputava a Propp a responsabilidade por opor forma e conteúdo. Em sua Morfologia do conto maravilhoso, extenso estudo sobre os contos populares, seu enredo, narrativa e personagens, Propp [1984a] detecta um tratamento específico da linguagem literária. Entre as décadas de 1950 e 60, ao ser divulgada em outras línguas, a obra de Propp logo se torna referência para estudos da literatura.

Algumas dessas edições trazem o debate travado entre os dois, como é o caso da edição brasileira de 1984, que traz o texto de Levi-Strauss [1984], A estrutura e a forma, em que apesar de reconhecer o valor antecipador da obra de Propp [LEVI-STRAUSS, 1984: 190], procura definir a diferença entre o estruturalismo e o formalismo. O formalismo, segundo ele, separaria o conteúdo da forma, que teria a primazia sobre o conteúdo, apenas um resíduo sem significado, enquanto o estruturalismo consideraria forma e conteúdo como sendo da 
mesma natureza, passíveis da mesma análise. O conteúdo provém da estrutura e a forma seria a estruturação do conteúdo [LEVI-STRAUSS, 1984: 194]. A resposta de Propp, Estudo estrutural e histórico do conto de magia, diz que seu trabalho não pretendia abarcar toda a literatura, sendo um estudo bem localizado de um tipo de narrativa, sem pretensões de se transformar em modelo aplicável a outras modalidades. E, mais importante, dizia não compreender como o formalismo poderia separar o que, em seu estudo, aparecia como unidade indissolúvel, o enredo e o tratamento da linguagem, ou seja, conteúdo e forma [PROPP, 1984b: 219-220].

A polêmica entre Propp e Levi-Strauss reforça as aproximações e as diferenças entre conceitos como estrutura e sistema e proporciona o acesso à dupla material e procedimento, sem, contudo, oferecer a profundidade de seus desdobramentos. Assim como o estruturalismo, o formalismo também evoluiu e se transformou no decurso do tempo, ganhando novos contornos e diferentes interpretações.

\section{A EXPERIÊNCIA RELACIONAL E DINÂMICA}

O formalismo se desenvolveu na Rússia a partir de 1914, reunindo grupos de estudiosos principalmente da lingüística, com teses muito aproximadas, porém distintas do futurismo russo, com o qual muitas vezes se confundiu. Entretanto, suas teses e teorias não se restringiram às obras da literatura, estendendo-se às obras de arte em geral. A teoria formalista, muitas vezes entendida como método formalista, engendra um outro par, material e procedimento (priom), que se define, por um lado, pela rejeição da dicotomia forma e conteúdo e, por outro, pela singularidade da proposição da obra como organização resultante da relação dinâmica entre material e 
procedimento. A obra é um todo indissolúvel e o material contém a informação sobre o procedimento específico que lhe pode dar uma configuração estética. O significado se atualiza nessa relação dinâmica [FERRARA, 1981: 5-7; 31-44].

Ao explicar o formalismo como método, Eikhenbaum [1973: 43-69] ressalta que o formalismo tencionava criar uma ciência que partisse das qualidades intrínsecas dos materiais. A matéria seria eminentemente formal, não deveria ser confundida com os elementos e a forma resultaria de procedimentos singulares sobre ela. A obra como integridade dinâmica, dotada de desenvolvimento próprio, só seria percebida e compreendida em relação as demais obras, por oposição e paralelismo. A arte seria definida, portanto, como processo dinâmico e evolutivo dotado de variabilidade permanente. O conceito de evolução na teoria formalista foi delineado por Youri Tinianov [1973: 119-134]. Segundo ele, tanto as artes quanto as obras constituem sistemas e estudar a evolução da arte é trabalhar sobre matéria acumulada, num processo em que uma forma de arte nova, ou uma obra nova surge para substituir outra anterior. Essa novidade, ao mesmo tempo em que corrompe o já estabelecido, tem o poder de transformar. Nessa dinâmica evolutiva, propõe a análise da obra através da relação mútua de seus constituintes e, simultaneamente, coloca-a em relação a outras obras semelhantes, diacrônica e sincronicamente, construindo uma análise relacional e dialógica.

Segundo as teorias formalistas, a obra deve ser deslocada do contexto social e histórico de sua produção, da influência da autoria, para centrar-se em si mesma, em suas qualidades sintáticas. O significado não se encontra no exterior, fora da obra em algum referente, mas na singularidade de sua organização. Nesse contexto, a relação entre material e procedimento tem papel preponderante. Assim como a 
linguagem poética encontra suas qualidades de ambigüidade na função poética de Jakobson [2001: 118-130], através da projeção, da superposição do princípio de equivalência do eixo de seleção sobre o eixo de combinação, a obra de arte encontra suas qualidades na sintaxe do tratamento específico dado ao material.

\section{A BASE SINTÁTICA DO PROCESSO}

Será Victor Chklóvski [1973a; 1973b] que, em 1929, num ensaio intitulado $A$ arte como procedimento, dará contornos mais definitivos ao par material e procedimento. Segundo ele, é preciso construir, através da linguagem, um modo de formar inusitado que provocará circunstâncias singulares de percepção. O objeto, a obra, devem ser extraídos de seu contexto habitual, provocando um estranhamento, uma desautomatização, dificultando a percepção, transformada em confronto, duração. Quanto mais difícil a percepção, mais qualificada a recepção.

"A arte é feita para dar a sensação da coisa como coisa vista e não enquanto coisa reconhecida; o procedimento da arte é o procedimento da representação insólita das coisas, é o procedimento da forma confusa que aumenta a dificuldade e a duração da percepção, porque em arte o processo de percepção é um fim em si mesmo e deve ser prolongado; a arte é o modo de viver a coisa no processo de sua consecução, em arte aquilo que está feito não tem importância". [CHKLOVSKI, 1973a: 16] *

O fazer da arte se concentra numa base sintática, na construção da linguagem como processo de pensamento. A inadequação entre linguagem e referente, provoca a apreensão

\footnotetext{
* Tradução de Lucrécia D’Aléssio Ferrara em A estratégia dos signos, 1981, p.34.
} 
de uma realidade complexa que solicita ver com outros olhos aquilo que é habitual. O significado está na relação entre a organização da obra e a ação de recepção. Nesse sentido, Ferrara resume:

"A arte deixou de ser comunicação de um significado para ser linguagem que se processa, que se estrutura e nisso engendra o seu significado. (. . .) O significado não é ou está, mas processa-se. Arte não é fruição, mas utilização, uso e posse. Ultrapassa-se os limites de um signo ou de uma cultura para se passar a defender o universo da linguagem e todo o conhecimento implícito no processo criador e na cognição humana". [FERRARA, 1981: 43-44]

Recorde-se que Alexander adota em sua tese a lógica dos conjuntos em que esses são constituídos por elementos e por suas respectivas relações e correlações. Os elementos só ganham significação quando colocados em relação, qualquer alteração em um deles pode alterar todo o conjunto. Outra questão relevante na síntese da forma é a correspondência entre os problemas que norteiam o projeto e seu processo de criação em busca da melhor solução, em que o processo é determinante da organização. O processo é um sistema constituído por um par: a análise que constitui próprio material traduzido em algoritmos que definem um procedimento específico, uma síntese da forma, o projeto.

Parece possível aproximar a tese de Alexander das teorias formalistas. Se a arte, em seu conjunto e em cada obra, a partir das teorias formalistas pode ser encarada como linguagem que é processo de pensamento, tanto na instância de sua consecução como de sua recepção e que esta base está apoiada sobre a concepção da organização sistêmica e relacional, Alexander procura apropriar o pensamento por um sistema que engendra seus procedimentos sobre a própria 
matéria do pensamento. $\mathrm{O}$ ato de projetar parte de um sistema onde o material é o conjunto de variáveis possíveis computadas de antemão que, postas em relação, indica a melhor solução e sintetiza a forma.

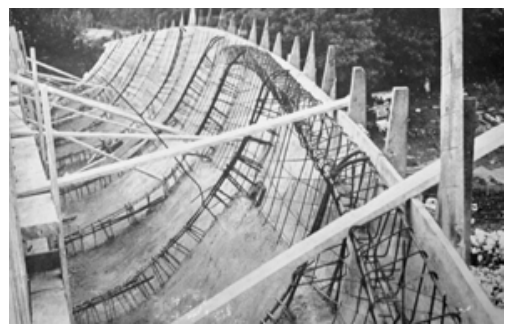

33 Ronchamp em obra.

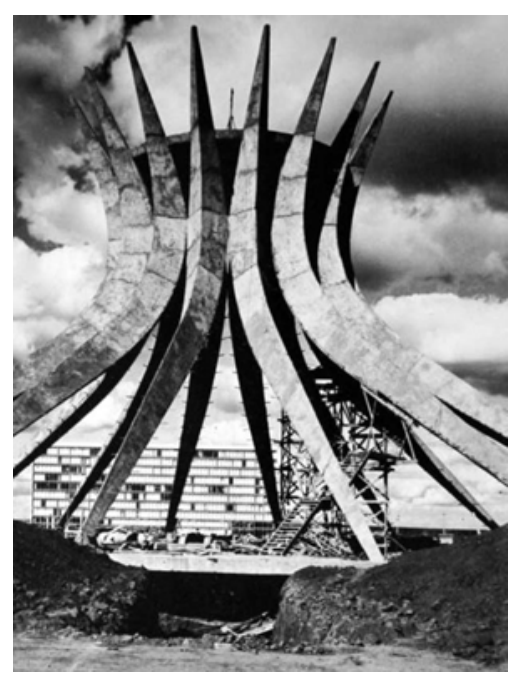

34. Niemeyer: catedral de Brasília

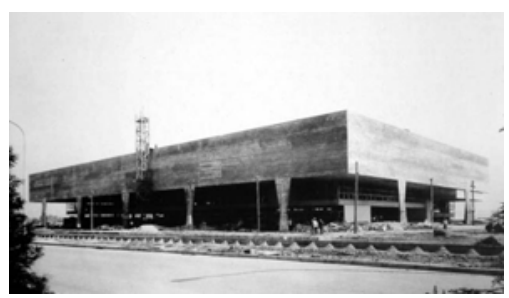

35. Artigas: FAU USP

\section{O MATERIAL ENSINA O FAZER DA FORMA}

Outras experiências podem fornecer exemplos para compreender a amplitude do par material e procedimento em seu sistema relacional dinâmico. O exemplo mais pertinente certamente é o concreto, material moderno por excelência. A primeira observação a ser feita sobre o concreto é que se trata de uma matéria em transformação dinâmica, que adquire sua configuração final mediante a utilização de uma forma. $\mathrm{O}$ concreto é uma organização sistêmica produto da relação entre outros materiais, combinados em doses precisas segundo cada caso. Sua constituição é eminentemente plástica, pastosa, moldável, quase líquida, portanto informe. Uma vez dominada por um molde, essa massa, quando seca, se apresentará com resistência construtiva e estrutural, como forma e estrutura. A plasticidade do material, informe, ensina que o procedimento necessário é construir, de antemão, seu negativo, seu receptáculo, seu molde, meta-forma. Sem essa potencialidade plástica do concreto, seria impossível realizar obras paradigmáticas do século XX. Corbusier não poderia ter concebido a estrutura Dom-ino, verdadeira hipótese posta em diagrama do desenvolvimento do pensamento estrutural modular moderno ou Ronchamp jamais poderia ter sido realizada sem a liberdade plástica dada pelo concreto. Os desenho de Niemeyer traduzidos em estruturas espaciais e os grandes vãos sobre apoios poeticamente mínimos da arquitetura moderna paulistana não poderiam ter se 
transformado em representantes significativos da moderna cultura arquitetônica brasileira.

Em movimento sincrônico, antes mesmo da formulação desses conceitos pelos formalistas, Gaudí, no final do século XIX, já operava seguindo essa relação entre matéria e procedimento. O caso mais evidente talvez seja a utilização dos arcos em catenária. Já se sabe que Gaudí utilizava largamente a construção de diagramas tridimensionais para testar suas soluções formais e estruturais complexas, que permitiam a alteração e a experimentação de outras hipóteses a partir da experiência. As catenárias são a forma adotada por uma corrente quando pendurada por dois pontos e suportando seu peso próprio. Sua forma pode ser alterada pendurando pesos ao longo do comprimento, transformando a catenária em arco funicular. A forma resultante possui a resistência necessária para vencer altura, comprimento e peso próprio. A singularidade de Gaudí está na construção de maquetes, verdadeiros sistemas abertos à investigação das possibilidades da linguagem arquitetônica, sobre as quais experimentava com a simplificação dos métodos de cálculo gráfico dos arcos que, na construção, trabalhariam outros materiais. Assim, um procedimento sobre o material, pendurar uma corrente, constituem as bases sintáticas que se oferece à análise das formas mais adequadas [GÓMEZ-SERRANO, 2004: 158-167].

Além desse processo de projetar formalista, temos que as obras do arquiteto catalão exigem uma recepção longa, pois provocam uma sensação de estranhamento. Gaudí é contemporâneo de Sullivan e da escola de Chicago, que forjaram a arquitetura dos arranha-céus de estruturas em aço e concreto e mentores da máxima a forma segue a função. Chicago assiste ao florescimento da racionalidade estrutural e construtiva que, mais tarde, seria adotada como conceito fundamental do movimento moderno. Em Barcelona, Gaudí 


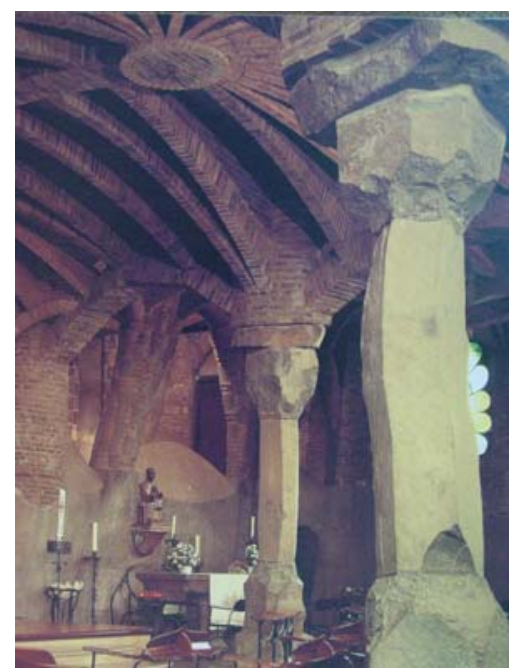

40.Gaudi: interior da igreja da Colônia Guell

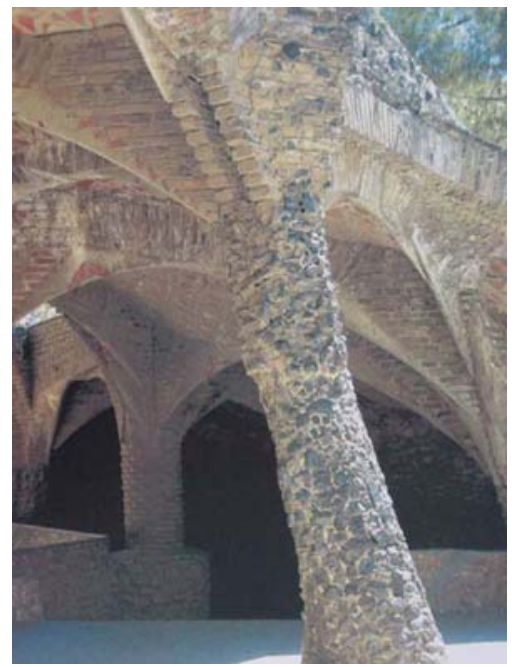

41. Gaudí: entrada da igreja permanece fiel aos materiais tradicionais, mas leva-os aos seus limites enquanto possibilidade de organizá-los segundo sistemas construtivos sempre transformados através da forma inusitada [BUXADÉ \& MARGARIT, 2004: 96-114]. A geometria para ele não serve para a funcionalização simplificadora do projeto e da arquitetura, mas sim como material diagramático, como hipótese sobre a qual aplicar procedimentos, operações, transformações, maclações. Sua arquitetura é repleta de analogias de toda a ordem, das formais às biológicas, utilizando um repertório pessoal sobre as possibilidades da cultura, à procura da forma complexa [ALSINA \& GÓMEZ-SERRANO, 2004: 72-95].

\section{DO PENSAMENTO À COMPUTAÇÃO}

\section{Parece inevitável que as teses de Alexander ao} procurarem representar o processo de desenho, a atividade de projetar através da linguagem simbólica da lógica matemática, apontem para as questões da computação e, conseqüentemente, do uso dos recursos computacionais para projetar em arquitetura. O que também leva a considerar que, do formalismo à síntese da forma, emerge não apenas uma nova racionalidade, mas uma maneira de pensar onde o pensamento como processo, mediação e linguagem, é matéria para o procedimento e é procedimento sobre a matéria, na produção do conhecimento, no processo de cognição do estabelecimento da linguagem sobre a linguagem. Para Peirce, o pensamento só pode ser conhecido através de signos e, se há pensamento, há linguagem. O pensamento funciona numa cadeia infinita, em que um pensamento se traduz em outro, quase-signo em estado de formulação, que só poderá ser conhecido através da mediação da linguagem, da 
representação através de outros signos, no processo de semiose [PEIRCE, 1995: 269-273; PLAZA, 1987: 17-23].

Morin [1999: 45-48; 129-139] concebe a computação como complexo organizador e cognitivo constituído pelas instâncias informacional - suas operações utilizam a informação binária do tipo sim / não, simbólica - toda a informação é codificada e organizada segundos sistemas padrão, memorial - armazenamento da informação que pode ser recorrida e programática - os princípios e as instruções que regulam o funcionamento de todo o sistema. A operação essencial da linguagem computacional se baseia na dialógica binária do sim / não, do 0 e 1, do ligado e do separado, também configura o procedimento específico de análise (decomposição) e síntese (reunião), aproximando-se, através da linguagem, da estrutura dialógica do pensamento. Assim, a possível distinção entre pensar - suspender o juízo, analógica e cogitar - exercitar a razão, lógica, faz surgir um terceiro, computar, que serve e amplia as possibilidades da linguagem. O pensamento ganha nova dimensão e se agita entre o cogito cartesiano e o computo moriniano.

Seguindo essa vertente, a lógica da arquitetura congrega projeto, computação e cognição, e se concretiza nas experiências de William Mitchell [1990]. Na verdade, Mitchell está preocupado em clarificar uma teoria computacional aplicada à arquitetura, demonstrando como a computação pode participar da invenção do projeto, através da criação de linguagens formais. Em suas experimentações, práticas e teóricas, Mitchell leva às últimas conseqüências a possibilidade, apontada por Alexander, de traduzir a linguagem da arquitetura em linguagem lógico-matemática através da teoria dos conjuntos ou lógica dos predicados ou das relações. 
Mitchell formula gramáticas que contém um vocabulário
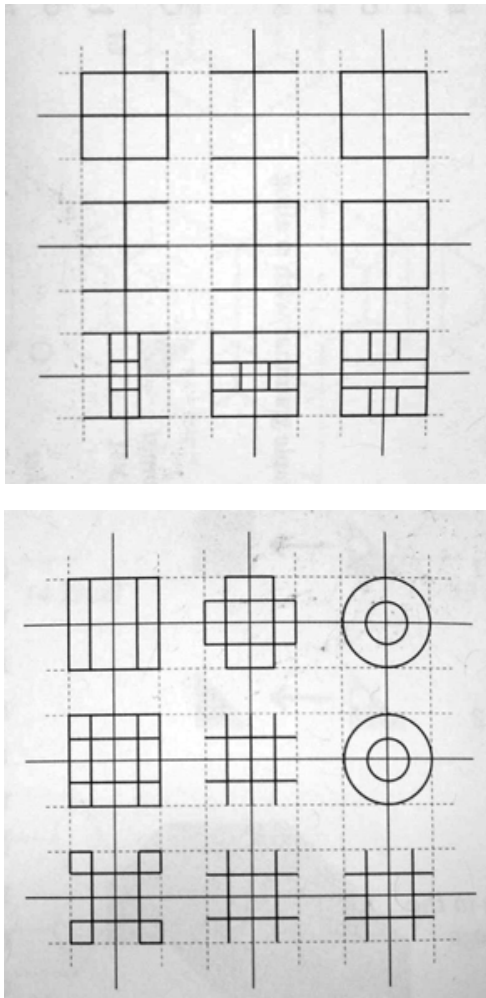

42 e 43. Diagramas para a construção de plantas, a partir de Durand.

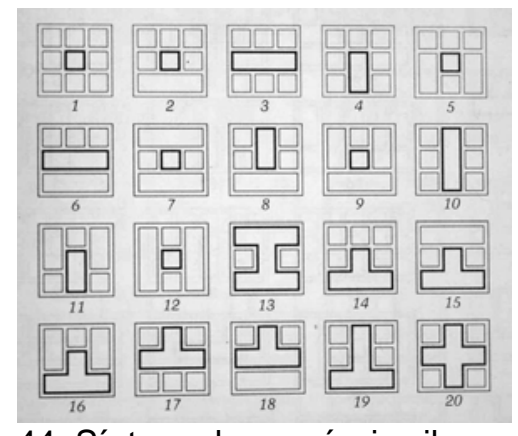

44. Síntese de possíveis vilas Palladianas segundo a lógica da sintaxe de formas e um elenco de regras para a operação sobre esses elementos formais, para os quais é possível associar certos predicados pré-definidos. O objetivo é fornecer o material para que o arquiteto encontre a melhor solução possível para determinado problema através de um procedimento especulativo de tentativa e erro. Esse problema tem que ser descrito em detalhes através de equações funcionais que possam servir de material que indique as melhores opções. Mitchell pretende demonstrar que toda a arquitetura se baseia em determinadas regras sintáticas aplicadas sobre determinados conjuntos de formas e que, através da decomposição, pode-se chegar a programas que contenham todas as possibilidades de síntese de uma determinada classe de edifícios, por exemplo [MITCHELL, 1990: 179-181].

Vários são os exemplos dados por Mitchell para a aplicação prática dessa computação arquitetônica. Acompanhadas de descrição minuciosa e ilustrações, são demonstradas linguagens arquitetônicas computacionais baseadas em figuras trapezoidais, no compêndio de Durand e nas vilas de Palladio. Essa última ilustra a decomposição das plantas das vilas Palladianas e a compilação de suas variáveis, seus elementos, dimensões, soluções espaciais e outros que, tomados como vocabulário, se associam obedecendo a regras e instruções, segundo critérios colhidos nas próprias obras estudadas. Essa linguagem, assim como outras, contém o conhecimento necessário para desenhar todas as vilas de Palladio e ainda oferece a possibilidade de criar novas vilas segundo sua linguagem [MITCHELL, 1990: 152-179].

\section{ALÉM DOS OLHOS DA MENTE}

Tanto a Síntese da forma como A lógica da arquitetura transitam entre as formalizações lógicas da matemática que se 
convertem em linguagem simbólica na computação. A linguagem computacional utiliza recursos conhecidos e, em alguns casos tradicionais, como na música, a associação de regras a elementos e o estabelecimento de certas relações singulares expressas por símbolos fazem parte da linguagem musical e se conhece por notação. Um símbolo associado a uma nota musical indica uma certa duração e um certo tom, permitindo que a música seja lida, tocada e arranjada sem ambigüidades, a computação utiliza um sistema de notações simbólicas para determinar atributos e qualidades das operações derivadas da linguagem [McCULLOUGH, 1996: 8596].

Esse recurso já havia sido experimentado em estruturas sintáticas por Noam Chomsky [1957] e procura, através da generalização, circunscrever a dinâmica constante do processo de criação da língua analisando a relação entre a sintaxe e a cognição. Sua visão é formalista, pois seu foco está na base sintática geradora de formas e, para dominar esse processo cognitivo, desenvolve um sistema de notações de regras transformacionais para gerar novas formas sintáticas ou estruturas sintáticas como ele as designa. Portanto, o princípio adotado por Alexander e Mitchell, fruto da lógica, aplicado em música, investigado pela lingüística, está na raíz da computação, desde Turing e sua máquina universal que segue instruções para operar.

No bojo das propostas de Mitchell está presente a experiência radical da gramática da forma (shape grammars) de Stiny [1975; 1978; 1980], que teve início em torno de 1975 na mesma Califórnia que viu surgir o Silicon Valley, o computador pessoal, os chips, a computação gráfica e a internet, resultado de experiências inovadoras. O objetivo central dessa gramática 


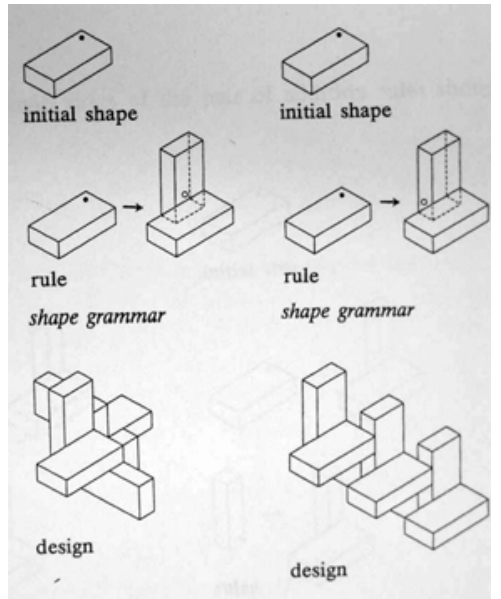

45. Terry Knight: Shape Grammar: sistema notacional

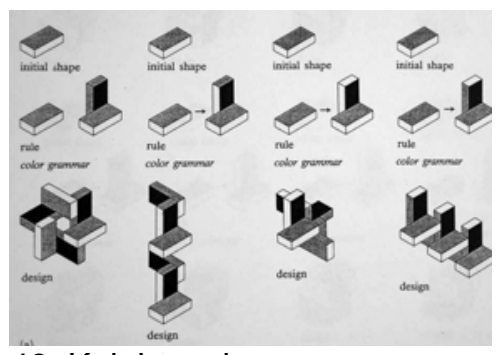

46. Knight: color grammar é a implementação de programas gráficos para a arquitetura com base na linguagem da computação, num processo de metalinguagem e analogia onde arquitetura e computação se engendram uma à outra, num movimento dinâmico e dialógico. Partindo dessa gramática, Terry Knight [1981; 1989; 1994] desenvolveu, pelo caminho inverso, a aplicação da linguagem da computação sobre modelos tridimensionais, através da definição de conjuntos de vocabulários e regras aliados a um sistema de notação que permite criar linguagens arquitetônicas pela experimentação material da lógica abstrata do computador.

A associação do par formalista material e procedimento à tese de Alexander, à lógica de Mitchell e à gramática da forma de Knight, passando pelo pensamento como computação, leva inevitavelmente ao computador como organização sistêmica e relacional capaz de fazer convergir para si todas as possibilidades na sua virtualidade polissensorial, informatizada e digital. O computador como espaço das virtualidades, espaço da invenção e reinvenção, está construído sobre inúmeros conhecimentos sintetizados através das formalizações simbólicas, que se processam como linguagem, mediação e pensamento, produção de conhecimento sobre um material que é também procedimento.

Alexander trata a lógica matemática como matéria para a organização da arquitetura como linguagem, formulando uma teoria cujo sentido é revelar a potencialidade da máquina numérica de base digital. O computador sempre esteve implícito como espaço da experimentação do projeto, da especulação processual, da invenção dos procedimentos sintéticos. Se, no despertar do século XXI, a compreensão do papel dos computadores permanece limitada, por volta de 1960 as dificuldades eram exponencialmente maiores. Nesses anos, frente às dúvidas sobre o papel do computador para o processo 
de desenho do espaço, Alexander respondia com a necessidade de precedê-las com a pergunta sobre os problemas que requerem a máquina para serem resolvidos.

"Nesse momento o computador pode mostrar as alternativas que conhecemos. Esta não é uma limitação do computador, mas de nossa capacidade para conceber, em abstrato, outros campos alternativos relevantes. (. . .) É uma ironia que o mesmo instrumento inventado para diminuir as complexidades imponha aos problemas que 0 desenho pode resolver restrições tão severas que a mesma fonte de complexidade tem que ser eliminada antes da utilização do instrumento que deve elucidá-la. Contudo, nosso trabalho consiste em aprender as ver as complexidades atuais do desenho de um modo tão claro que poderemos usar uma máquina para decifrá-los." [ALEXANDER, 1971: 9-15]

As mudanças decisivas nas ciências e nas artes ocorridas a partir da segunda metade do século XX, começam a ganhar substância para a arquitetura com a introdução das tecnologias eletrônicas nos processos de representação e produção. Só com a chegada dos computadores, segundo Eisenman [1993], a arquitetura enfrenta o desafio de substituir a máquina mecânica como seu referencial. O computador opera uma convergência, desloca os tempos do pensar e do fazer para um tempo e espaço simultâneos em que todos os conhecimentos podem participar na consecução da experimentação e da reflexão. Dessa convergência, participam as ciências e as tecnologias que, transformadas em matéria numérica, tornam-se virtualidades passíveis de atualização, linguagens postas em relação de base digital binária para a produção de significados. 
Talvez seja a constituição polissêmica que permite uma 'estranha identificação sem reconhecimento' às realizações do virtual, como menciona Lucrécia D’Aléssio Ferrara ao tratar da imagem virtual. Ampliando suas premissas para a noção de virtual como base (i)material da computação, nesse universo dialógico e relacional entre memórias codificadas e virtualidades pressentidas e imaginadas na interação entre emissor / receptor e máquina, o processo incide sobre a natureza da linguagem, produz-se um estranhamento tecnológico [FERRARA, 1998: 8-9]. Se a imagem virtual está 'além dos olhos', os 'olhos da mente' encontram nela sua extensão. 
capítulo 3

\section{a linguagem da experimentação}

ou da arquitetura como ordem

à arquitetura como processo e organização

3.1 a invenção da tecnologia digital ou isto matará aquilo

3.2 arquitetura do espaço virtual 
Até a invenção da prensa de tipos móveis de Gutemberg, no século $X V$, a arquitetura é a escritura universal. Na segunda metade do século XIX, a proliferação de obras impressas na forma de folhetins circulando por Paris era tão intensa que fez com que Vitor Hugo declarasse a morte da arquitetura. Sua declaração significava de fato que, ao mudar a forma de representação do pensamento, o suporte de sua manifestação, mudaria também a natureza desse pensamento. O livro, meio mais fácil, simples e durável, vai aniquilar a arquitetura [CHOAY, 1992: 323-327]. Esse temor de superação a ponto de apagamento de um meio sobre o outro é recorrente, mas como chamou a atenção Décio Pignatari [1988: 489], os efeitos de um novo meio sobre os já existentes são sempre positivos, no sentido de provocar renovações.

A invenção tecnológica instaura uma nova relação da cultura com o tempo, o espaço e a linguagem. Os tipos móveis talvez sejam a primeira experiência de reprodução de uma linguagem, a escrita, através de unidades discretas, isoladas e passíveis de combinação e variação. Cada tipo é um dígito, representa uma letra, um sinal, que posto em relação sistêmica com outros tipos, formará o texto. Como diz Derrick de Kerckhove [1997: 69-73], esse modo de organização digital aparece com o alfabeto, modelo para a codificação e digitalização de toda a cultura, da estrutura atômica à cadeia genética e aos bits do computador.

Segundo Kerckhove [1997: 61], qualquer tecnologia que afete a linguagem, afetará também o pensamento. Assim, o 
alfabeto considerado como tecnologia afeta diretamente a linguagem, pois os dígitos que representam os sons da fala, seguindo as regras, podem ser escritos, reproduzidos e armazenados, estabelecendo uma organização linear que coloca o analítico sobre o contextual. É apenas na sucessão das unidades em relação, na análise de cada letra e palavra em relação seqüencial que se pode compreender o todo do texto. [KERCKHOVE, 2001: 8-10]

O efeito mais visível do que se pode considerar como revolução alfabética, modelo de organização do pensamento é, como uma pele da cultura, na definição de Kerckhove [1997: 64-67], a perspectiva. Contemporânea da prensa de tipos móveis, a perspectiva é o princípio analítico aplicado à interpretação do espaço, refletindo a maneira de processar a informação através do olhar e possibilitando sua reprodução em imagem. Alinhar os objetos no espaço de acordo com suas relações de proporcionalidade é efeito da prática da escrita e da leitura. A proporcionalidade, calcular relações dimensionais, distâncias, razões (na língua inglesa a raiz latina ratio, serve para formar rational, racional) do espaço pelo tempo é representação da racionalidade através da visão [KERCKHOVE, 2001: 8-10]. Olhar que pensa, os olhos da mente.

\section{TECNOLOGIA DO OLHAR}

À compreensão da perspectiva como resultado de uma transformação do pensamento revestido em tecnologia, instaurando alterações na linguagem se agregam questões que se referem à sua construção científica definidora da cultura humanista antropocêntrica. Sua invenção é freqüentemente reportada ao Renascimento, embora Erwin Panofsky [1999] 
tenha demonstrado sua existência desde a Antiguidade. Entre tantas considerações significativas, Panofsky diz que a perspectiva do Renascimento remete à sua definição matemática. Investigando a origem da perspectiva, Hubert Damish [1995] afirma que o fundamental é reconhecer que ela representa a complexidade dos problemas científicos e filosóficos que se colocaram os artistas entre os séculos XV e $\mathrm{XVI}$.

Duas coisas de fato interessam compreender sobre a perspectiva. Uma é sua relação com o olho, com a visão que resulta em um certo tipo de imagem. Significando em Latim 'ver através de', foi definida no tratado Da pintura por Alberti [1992], como janela. O olho como janela perceptiva e sua abstração em recorte de uma fração do espaço. A outra é sua relação com a construção do espaço, da arquitetura. Entre tantas acepções, perspectiva também pode designar 'visão de arquitetura' [DAMISH, 1995: 271]. Entre visão e espaço, se encontra a figura do arquiteto, personificada pela História em Brunelleschi.

Como máquina de visão, como tecnologia que se traduz em método para instruir a prática, a perspectiva cria um dispositivo, um intersector, um instrumento de mediação entre sujeito e realidade. O que é visto através dessa janela, um quadro ordenado ortogonalmente por linhas paralelas às suas bordas (conforme o esquema de Durer, que Leonardo da Vinci substituiu por um vidro), também é aí projetado e reproduzido em suporte físico. Essa projeção da imagem a partir de um centro organizador que se confunde com o olho obedece a regras estritas de composição, de ordenação dos elementos no espaço [COUCHOT, 2003: 28-31]. A representação assume um caráter maquínico, automático, científico, no campo da abstração mental. 
Com freqüência, um outro dispositivo para representar o espaço em três dimensões é esquecido pela história da perspectiva e da própria arquitetura: a tavolleta de Brunelleschi [DAMISH, 1995: 89-139]. A tavolleta é um pequeno painel pintado contendo um orifício através do qual se olha em direção a um espelho, propiciando uma retro-visão, um olhar por trás dos olhos. É um dispositivo inserido no espaço, que além de mediação ou plano de projeção, é também suporte para reflexão de uma imagem real. Essa instalação pode ser considerada como protótipo, modelo da visibilidade do espaço moderno, confluência da arte e da ciência, percepção e racionalização. Seria também raiz de todo o desenvolvimento das tecnologias de criação de imagem, da hibridização das tecnologias, ao fazer convergir o analógico e o digital, prefigurando o campo das imagens virtuais. [BELLOUR, 1993: 214-230; PARENTE, 2002] É a partir do experimento da tavolleta que toda a teorização da perspectiva se realiza. Mais do que janela, mediação, a perspectiva é o olho no espaço.

Olho e pensamento se encontram na perspectiva instauradora do sujeito, na determinação de um ponto de vista, idéia e lugar [CHAUÍ, 1988: 35-37]. Olhar como observação e experimentação, o especular que pensa enquanto vê; como conhecimento, perspecto, olhar com atenção para todas as direções, cuja ciência é designada óptica ou perspectiva:

"Com ela, o olho do observador se faz medida do visível e prepara, na filosofia, o advento de um sujeito do conhecimento que se julga capaz de evidência de intuição porque, do lugar onde se encontra, tudo vê e vê completamente". [CHAUÍ, 1988: 37] 


\section{A ARQUITETURA NO CENTRO DA REVOLUÇÃO}

A cultura tecnológica do Renascimento, da qual foram protagonistas Brunelleschi e Alberti, tinha na arquitetura um de seus motores mais potentes, trabalhando no sentido de resignificar não só a própria disciplina, mas os estatutos da humanidade. Como disse Peter Eisenman [1999: 39], Alberti deu um sentido de anterioridade à arquitetura através da história ("a perspectiva como construção intelectual da dimensão espacial em que a ação humana é histórica". [ARGAN, 1992: 114]) e Brunelleschi introduziu um elo de exterioridade através da presença da física e da matemática na construção da forma perspéctica. O grande experimento de Brunelleschi foi sem dúvida a cúpula de Santa Maria del Fiore em Florença.

Além de inovar na concepção da arquitetura, criando a noção de projeto, cosa mentale, e no canteiro, no processo de construção da estrutura que passava a não depender de armações para sustentar a obra em andamento, a cúpula apresenta também uma forma nova e uma estrutura como sistema orgânico articulado. Um sistema que além de estrutura auto portante é forma de representação perspectivada, no espaço, em que as nervuras convergem para um ponto central. Segundo Argan [1992: 95-103], a cúpula é o signo dessa cultura tecnológica, uma máquina espacial que demonstrava uma nova concepção do espaço e uma nova tecnologia, de uma nova realidade política, cultural e social.

A arquitetura, transitando entre a filosofia, a ciência, a arte e a tecnologia, está no centro das transformações da cultura, contribuindo para a constituição de uma visão humanista. Eisenman apresenta assim a questão: 
"Não foi por acaso que a invenção de Brunelleschi, a perspectiva de um ponto de fuga, correspondeu a uma época em que o paradigma teológico e teocêntrico foi substituído por uma visão de mundo antropomórfica e antropocêntrica. No rastro dessa mudança, a perspectiva passou a ser o meio através do qual a visão antropocêntrica se cristalizou na arquitetura. Contudo, o sistema de projeção de Brunelleschi era mais profundo em sua eficácia do que toda a mudança estilística subseqüente, pois ratificou a visão como o discurso dominante na arquitetura, desde o século XVI até hoje. Deste modo, não obstante as repetidas mudanças de estilo desde a Renascença até o Pós-Modernismo, e apesar de tantas tentativas no sentido contrário, o sujeito humano que "vê" - uniocular e antropocêntrico - ainda é o termo discursivo primordial da arquitetura. A tradição da projeção planimétrica na arquitetura persistiu incontestada porque permitiu a projeção e, portanto, a compreensão do espaço tridimensional em duas dimensões". [EISENMAN, 1993: 15]

Parece que, desde então, a arquitetura não mais encontrou sentido como disciplina de dimensões tão alargadas, com uma visão tão ampla de sua própria ontologia. Nem a relação admirável e ao mesmo tempo de admiração das vanguardas pela revolução industrial teve um papel de tal consistência. Ao contrário, o assentamento do paradigma parece ter provocado uma rejeição das tecnologias que tratam da visão, do olhar no desenvolvimento das tecnologias de concepção do espaço arquitetônico. Mesmo que, como demonstrou William Mitchell [1992: 117-134], haja apenas uma reconfiguração do olhar, uma vez que o mesmo modelo de visão foi utilizado para fabricar grande parte dos recursos informáticos para a construção da tridimensionalidade. 


\section{QUEBRAR O PARADIGMA}

Seria de se esperar que a arquitetura, aliada dos desenvolvimentos tecnológicos e irmanada na conformação de uma visão de mundo paradigmática, prosseguisse com seu papel moderno, de inovação. Frente ao universo eletrônico, às máquinas informáticas, à tecnologia numérico-digital, a arquitetura parece sofrer de paralisia. Peter Eisenman talvez tenha sido o primeiro a compreender a questão, ou pelo menos a formular o problema do ponto de vista da arquitetura:

"O paradigma eletrônico coloca um desafio poderoso para a arquitetura uma vez que define a realidade em termos de mídia e simulação, valorizando a aparência sobre a existência, o que "pode ser visto" sobre "o que é". Não mais aquilo que é visto tal como já conhecíamos, mas antes um olhar que não pode mais interpretar. $A$ mídia introduz ambigüidades fundamentais em como e o que vemos. A arquitetura resistiu a esta questão porque, desde a importação e absorção da perspectiva pelo espaço arquitetural no século $X V$, ela vem sendo dominada pela mecânica da visão. A arquitetura assume assim o olhar como algo preeminente e de certo modo natural aos seus próprios métodos, e não algo a ser problematizado. É precisamente este conceito tradicional do olhar que o paradigma eletrônico coloca em questão". [EISENMAN, 1993: 14-15].

A problematização do olhar proposta por Eisenman traz consigo algumas questões subjacentes, senão de fundo. Primeiro, o problema não está circunscrito ao eletrônico, alcançando a amplitude das tecnologias digitais concretizadas em máquinas informáticas, numéricas. O eletrônico constitui apenas o campo onde a informação convertida em linguagem simbólica, numérica, pode fluir na forma digital. Segundo, a noção de que a perspectiva, não é instrumento de mediação 
abstrato, que conforma uma imagem do real, mas é a própria imagem da realidade. Como se essa imagem, técnica, não fosse resultado do pensamento e da racionalização, conformando assim uma tecnologia.

Segundo Couchot [2003: 93] toda a tecnologia é solidária das ciências e de suas teorias, representando formalizações matemáticas e assim suplantando a noção de técnica. Por outro lado, como diz Deleuze [DELEUZE e GUATTARI, 1997a: 98], nada mais falso do que o problema da perspectiva, uma maneira histórica de ocupar o espaço pelas diagonais, que o precipita no buraco negro do ponto central. É preciso lembrar que, em 1963, na tese de doutorado no MIT de Ivan Sutherland que não era arquiteto, o Sketchpad, que significa literalmente bloco de desenho, foi pensado como interface para projetar, inaugurando conceitos como a interatividade e a simulação.

Ao tomar o lugar da visão, ao se colocar como mediação entre o olhar, a visão e o espaço, o digital, sob a forma de máquina informática, se apresenta como uma barreira incompreensível, quase intransponível aos olhos da arquitetura. Isto porque a idéia de máquina sempre esteve ligada ao trabalho mecânico, de reprodução de força e energia. E a essa compreensão da máquina sempre se associou ao mito da substituição do trabalho humano, da superação do homem, do apagamento do sujeito criador.

Em Máquina e Imaginário, Arlindo Machado [1993: 36-37] comenta o conflito entre criador e máquina que faz surgir o temor de seu predomínio que poderia transformar o artista em mero cumpridor de tarefas, seguidor de rotinas redutoras. Para desmontar esse mito da subserviência à máquina que limita 0 potencial criativo, Machado levanta dois aspectos. Primeiro, que 
qualquer processo cultural impõe limitações. Assim, moldar o barro exige cumprir determinados procedimentos e enfrentar as características da matéria tanto quanto qualquer outro processo tecnológico. E segundo, frente ao mito do esgotamento do restrito arsenal de modelos inscritos na máquina, que não ofereceria um campo de experimentação adequado às artes, Machado demonstra não haver nenhum processo técnico que já tenha esgotado seu potencial criativo, bastando analisar a história da fotografia.

\section{INFORMAÇÃO SOBRE LINGUAGEM}

Em denso e extenso estudo sobre a tecnologia na arte, as considerações de Edmond Couchot [2003] fornecem várias entradas para compreender essa relação e as possibilidades de criar uma arte tecnológica do numérico digital. A informática, ciência do tratamento automático da informação fornece, além das máquinas, a linguagem de programação [COUCHOT, 2003: 193], espaço comum representado por imagens para onde converge toda a cultura. Assim, as artes, incluída a arquitetura, para sustentar seu papel crítico devem manter e afirmar suas diferenças com a ciência e com a tecnologia, substituindo suas certezas pelas incertezas da sensibilidade [COUCHOT, 2003: 309]. Entre os inúmeros problemas colocados pelo digital um dos mais perturbadores talvez seja o atrito constante entre tradição e inovação. A contemporaneidade assentada sobre sistemas de regulação e ordenação estabelecidos no passado, se vê forçada a se adequar à revolução tecnológica irreversível que impõe a reorganização desses mesmos sistemas. Dividida entre o tempo da história que demora e o tempo real febril, das trocas dialógicas, a cultura se despedaça entre a reflexão e o reflexo. [COUCHOT, 2003: 305]. 
Desde o paradigma colocado pela perspectiva, a cultura está sob o predomínio da imagem. É essa questão da imagem que Eisenman aponta como crucial para a interpretação dos arquitetos. Couchot explica as mudanças provocadas pelo digital no campo da imagem, que podem ser tomados para compreender o próprio estatuto da tecnologia que a conforma:

"No domínio próprio da imagem, o numérico introduz uma outra modificação. Ele rompe as relações que ligam a imagem, o objeto e o sujeito. A imagem numérica não é mais uma projeção ótica de um objeto interpondo-se entre este e o sujeito e mantendo-os à distância um do outro constituindo assim o seu estatuto. A imagem não mantém mais nenhuma ligação física nem energética com o real; ela é a expressão de uma linguagem específica - a linguagem dos programas informáticos alimentados por algoritmos e por cálculos, ao passo que a interatividade a torna dependente das reações do observador. As técnicas de síntese não propõem uma representação do real mais ou menos semelhante, mas uma simulação. Enquanto a representação ótica se limita ao aspecto visível do real, reduzido à dimensão bidimensional do plano de projeção ou de inscrição, a simulação numérica reconstrói o real a partir de descrições da linguagem lógico-matemática, eventualmente no seu aspecto visível (bi ou tridimensional) mas, sobretudo, no devir virtual que conhecerá no curso de suas interações com o observador. Simulação e interatividade estão ligadas. Simulamos para interagir. O numérico introduz uma nova ordem visual, geralmente mais perceptiva que substitui a representação (...) pela simulação do real." [COUCHOT, 2003: 157].

A simulação não é simulacro, pois não pretende imitar ou se fazer passar por real, mas propõe sua substituição por um modelo lógico-matemático, uma interpretação formalizada 
(algoritmica), uma racionalização da realidade. É herdeira da cibernética, é um modelo e como tal exige teorias e hipóteses [COUCHOT, 2003 176]. O espaço da simulação é sem lugar, sem topos, utópico, e sua existência se liga à interatividade, regime dialógico multimodal, que opera a complexidade das informações, a diversidade de suas traduções e a velocidade das trocas em tempo real. O digital é, portanto, determinado por um topos próprio e por um chronos distintivo. A temporalidade do virtual é autônoma em relação à temporalidade de fato. $\mathrm{O}$ tempo de síntese é aberto, sem orientação particular, sem começo nem fim, seguindo as leis imaginadas pelo usuário. Institui um tempo ucrônico, tempo dos possíveis, das eventualidades, dos acontecimentos [COUCHOT, 2003: 164170].

O digital, integrando os procedimentos de criação, é um consumidor voraz, devorador de modelos das ciências que, através das linguagens de programação, se transformam em materiais e ferramentas para a simulação interativa. Assim, a geometria empresta seus modelos para a construção de sólidos que recebem tratamentos derivados de curvas matemáticas e dos fractais. Os volumes são decompostos utilizando sistemas de partículas da química que permite simular materiais. A física empresta seus modelos para simular o movimento dos objetos. A aplicação da luz recorre à ótica e as cores são criadas a partir de estudos da colorimetria. A mecânica dos fluídos empresta seus modelos para simular movimentos das matérias naturais como a água. A botânica serve de inspiração para simular estruturas vegetais. A biologia auxilia a criar processos evolutivos. [COUCHOT, 2003: 188-194]

O processo computacional precede qualquer outra informação e o artista, como um programador, imagina um algoritmo que, como nos programas informáticos, encontra sentido em sua aplicação, como ferramenta dialógica 
[COUCHOT, 2003: 119]. As ferramentas e os materiais são símbolos, expressões lógico-matemáticas que descrevem os objetos ou imagens que contem informações sobre o devir do objeto, suas transformações, deslocamentos, interações, no tempo e no espaço [COUCHOT, 2003: 162-163].

"No domínio da arte, o numérico renova totalmente as ferramentas e os materiais que não são mais os do mundo real, mas aqueles da simulação: o artista não trabalha mais com a matéria nem com a energia, mas com programas, direta ou indiretamente. Ora, cada um desses programas só é concebível recorrendo-se a modelos de simulação que são todos produtos da ciência. A ciência então penetra sem rodeios no coração de ferramentas e materiais. Deste fato decorre uma experiência tecnestésica de uma complexidade sem precedentes. Não é somente num outro espaço e num outro tempo que o obreiro é mergulhado, mas é também uma outra concepção do mundo que ele desposa, sem querê-lo, imposta pela razão científica". [COUCHOT, 2003: 19]

O espaço, a arquitetura não se encontram mais derivados de uma ordem visual recortada em janela, limite das linhas em fuga diagonal para um centro organizador. A arquitetura, seu espaço, se encontra à deriva nos meandros da linguagem, na fluidez dos processos de reflexão e organização: do plano da janela em que se projeta a profundidade ao mergulho na tela sem tempo nem lugar.

\section{REDEFINIÇÃO DO CONCEITO DE MÁQUINA}

Parece existir, como diz Guattari [1992: 15-16], uma atitude anti-modernista avessa às inovações tecnológicas, especialmente as ligadas ao digital. E não se trata de considerar que essas inovações sejam positivas ou negativas, 
mas de postura e abordagem. Ele afirma a necessidade de ampliar o conceito de máquina, para além da referência técnica. Existe uma essência maquínica que reveste o pensamento e as realizações, que se encarna em uma máquina técnica, mas igualmente no meio social, cognitivo ligado a essa máquina conjuntos sociais também são máquinas, o corpo é uma máquina, há máquinas científicas, teóricas, informacionais [GUATTARI, 1992: 44-52].

"Embora seja comum tratar a máquina como um subconjunto da técnica, penso há muito tempo que é a problemática das técnicas que está na dependência das questões colocadas pelas máquinas e não o inverso. A máquina tornar-se-ia prévia à técnica ao invés de ser a expressão desta". [GUATTARI, 1992: 45].

Segundo Foucault [DELEUZE, 1998: 167-179] para cada tempo histórico, para cada formação da sociedade é possível corresponder um tipo de máquina. Assim, na formação histórica clássica, que pensa o infinito, o signo da cientificidade é a procura do continuum prolongável. As ciências são gerais, indicando uma ordem de infinitude: história natural, história da riqueza e gramática geral. À soberania da força correspondem máquinas simples, alavancas, roldanas, prolongamentos da força do homem. Na formação histórica do século XIX, as forças do homem se colocam em relação a forças de finitude: a vida, o trabalho, a linguagem, tripla raiz de finitude que faz nascer a biologia, a economia política e a lingüística. Disciplina e normatização dos saberes se ligam a máquinas energéticas, mecanizadas, da produção e da propriedade. Superadas essas idades do humanismo, desponta uma formação do futuro caracterizada pela dispersão, em que a linguagem tem um papel privilegiado em relação à vida e ao trabalho. $\mathrm{O}$ trabalho $\mathrm{e}$ a vida se desprendem da biologia e da economia. A vida dispersa se reúne no código genético e o trabalho dispersado 
se reúne nas máquinas de terceira geração, cibernéticas ou informáticas. A noção de linguagem se faz possível pelo desprendimento da literatura à lingüística e daí para seu descolamento do verbal. Não se está mais diante da elevação ao infinito, nem da finitude, mas de um finito-ilimitado: um número finito de componentes produz uma diversidade quase ilimitada de combinações, característica das cadeias do código genético ou das potencialidades do silício nos computadores e nas possibilidades de retorno da linguagem sobre si.

Se toda máquina é representação de sua época, se são resultado de tecnologias sociais antes de materializarem técnicas [DELEUZE, 1998: 64-65], se toda máquina é a materialização do pensamento, comportando a inscrição de uma inteligência, [SIMONDON, 1969: 120-125], o computador como máquina que reúne tecnologias, linguagens, conhecimentos e idéias, coloca a arte numa prática social de extensão jamais vista [MACHADO, 1993: 44]. Como máquinas, os computadores são encarnações das tecnologias da inteligência [LÉVY, 1993], campo aberto, conflituoso e parcialmente indeterminado, características próprias do universo da arte. Para as artes, assim como para a arquitetura, os computadores são máquinas semióticas [GUATTARI, 1992: 36; MACHADO, 1993: 34], máquinas abstratas na raiz da linguagem, máquinas de representar o pensamento. Máquinas abstratas que produz o conhecimento por simulação, através da exploração de modelos complexos [LÉVY, 1993: 121-126].

O digital, por sua natureza numérica e simbólica, no sentido matemático do termo, torna possível todo o tipo de mediação entre linguagens formais e representações sensíveis. As máquinas digitais propõem uma relação homem-máquina de um tipo completamente diverso, em que, juntos, realizam 
melhor as tarefas do que separados [SIMONDON, 1969: 120125]. O digital é, antes de tudo, linguagem encarnada por modelos matemáticos e programas informáticos [QUÉAU, 1993: 91-99] e, assim, a máquina ultrapassa a dimensão de extensão da força e se apresenta como prolongamento de nossa humanidade [SIMONDON, 1969: 120-125], o que permite recuperar o papel da visão, uma vez que visão e computação tendem para a abstração, para a invenção e para a descoberta [McCULLOUGH, 1996: 233]. O 'ver através de' ganha novos significados.

Assim como o digital opera uma convergência de modelos das ciências na conformação de uma lógica de hibridação de variadas possibilidades, essa maleabilidade permite inúmeras explorações no campo do projeto da arquitetura, agora na qualidade do virtual. Não há uma única formulação teórica fruto de reflexão e prática sobre a mediação digital. Tampouco uma visão particular pode ser considerada como mais qualificada do que outras. As visões se desdobram em aceleração crescente, se multiplicando, tornando a cena da arquitetura mediada pelo digital multifacetada, em constante renovação. Esforços para acompanhar o desenrolar dessa dinâmica têm sido divulgados por alguns periódicos e editores, em que se destacam a revista inglesa $A D$ - Architectural Design, que vem lançando seguidos números temáticos e a coleção The IT revolution in architecture (A revolução das tecnologias de informação na arquitetura), editada por Antonino Saggio e publicada pela suíça Birkhäuser. 
No bojo dessa dinâmica está a primeira geração de arquitetos que, nascidos sob a lógica do computador, foram formados pressupondo sua utilização na atividade de projeto, contando com os recursos tecnológicos dos cursos de graduação e usufruindo possibilidades de exploração reflexiva desses recursos em programas de pós-graduação de universidades norte americanas, européias e asiáticas. Em um pequeno, contudo importante estudo de Christian Pongratz e Maria Rita Perbellini [2000], foram batizados de Natural born caadesigners, o que poderia ter a possível tradução para o português de arquitetos digitais de nascença.

Integrante dessa geração, Marcos Novak [1995] observa que, em meados do século XVIII, a congruência entre os modos de compreender o mundo e os modos de conceber a arquitetura é rompida pelos contínuos desafios colocados pelas ciências à geometria euclidiana. Até aquele momento, a arquitetura ainda congregava as concepções e as representações do espaço ocidental. Contudo, assolada por sua inexorável materialidade, incapaz de acompanhar os avanços científicos, a arquitetura deixa de representar a pontade-lança de nossas visões de mundo e se volta para problemas cada vez mais estreitos, até que se transforma em atividade exclusivamente associada à mera construção utilitária.

Nesse sentido, parece correta a observação de Roy Ascott [1995] ao afirmar que o problema da arquitetura ocidental é que ela esteve sempre muito preocupada com suas própria construtividade, demonstrando quase nenhum interesse pelas mudanças radicais operadas em outros campos do conhecimento e pouca aptidão para indagar sobre o futuro. Segundo ele, somos ao mesmo tempo mediados e expandidos por computadores, meio que, para conceituar e perceber a 
realidade envolve mais do que simples mudanças quantitativas no como vemos, pensamos e agimos. Para Ascott, o computador significa uma mudança qualitativa no que somos, obrigando a constituição de uma faculdade inteiramente nova que ele chama de ciberpercepção. É possível reconhecer o surgimento de um modo de vida ciber, que vai além de ser apenas um prefixo em voga - cibershot, ciborgue, cibercafé, definindo nossa relação com as tecnologias, com a cultura e com o mundo de um modo geral. Nossas ações, nossas atividades, o fazer e o pensar são comandados pelo fluir da informação.

\section{A VIRTUALIDADE DO CIBERESPAÇO}

Provavelmente o termo ciber foi pela primeira vez adotado pelo escritor William Gibson [1984], que em sua ficção Neuromancer descreve outra modalidade de experiência ambientada em espaços permeados pelas tecnologias digitais. Pertence a ele a criação do neologismo ciberespaço:

"Ciberespaço. Uma alucinação consensual experimentada diariamente por bilhões de usuários legítimos, em cada nação, por crianças sendo ensinadas conceitos matemáticos. . . Uma representação gráfica da informação abstraída dos bancos de todos os computadores no sistema humano. Complexidade impensável. Fileiras de luzes alcançando o não-espaço da mente, feixes e constelações de dados. Como as luzes da cidade, desaparecendo..." [GIBSON, 1984: 51]

De alucinação coletiva, o ciberespaço passou a designar os espaços relativos ao computador, da sua interioridade como suporte à sua exterioridade como meio relacional. Uma das primeiras tentativas para abarcar as várias dimensões designadas pelo termo ciberespaço foi realizada pelo arquiteto 
Michael Benedikt [1991], que organizou e editou uma série de ensaios dedicados ao tema do ponto de vista de distintas áreas do conhecimento. Nos primeiros passos do ciberespaço (Cyberspace: first steps), a imagem realizada por Gibson, mesmo que distópica e ficcional, é considerada a visão antropológica mais sofisticada e detalhada do ciberespaço, com descrições de suas facetas sociais e econômicas, além de delinear a forma da pós-industrialização avançada [BENEDIKT, 1991: 32].

Pierre Lévy [1999] realizou extenso trabalho procurando circunscrever a dimensão do ambiente em que se desenrola esse estado de coisas, denominada por ele de cibercultura. Segundo Lévy, o ciberespaço é o meio de comunicação resultado da rede mundial de computadores, especificando desde a infra-estrutura digital que abriga um universo de informações até os usuários dos sistemas envolvidos. E cibercultura é o conjunto das tecnologias, das práticas e dos modos de pensamento, o todo das representações que se manifestam no ciberespaço [LÉVY, 1999: 17]. Esse espaço e essa cultura, resultado das transformações tecnológicas que promovem a informatização, a digitalização e a virtualização exigem, por sua vez, uma transformação da percepção.

Segundo Ascott, a ciberpercepção é uma outra compreensão, um modo inteiramente diferente de enxergar o todo, de fluir nos ritmos dos processos e dos sistemas. Vemos e pensamos de modo linear, uma coisa depois da outra, uma coisa escondida atrás da outra, levando a esta ou aquela finalidade e, ao longo do caminho, dividimos o mundo em categorias e classes. A ciberpercepção significa ter um sentido do todo, adquirindo uma visão panorâmica dos eventos, como a visão do cosmo do astronauta, como a visão sistêmica do cibernauta. É uma questão de retroalimentação super rápida, acesso a massivos bancos de dados, interação com uma 
multiplicidade de mentes, ver com milhões de olhos, ouvir os sussuros mais sutis do planeta, alcançando a imensurabilidade do espaço e até mesmo a fronteira do tempo. A ciberpercepção é a antítese da visão afunilada do pensamento linear. É a percepção simultânea de uma multiplicidade de pontos de vista, uma extensão pluridimensional do pensamento associativo. É o reconhecimento da transitoriedade de toda hipótese, da relatividade de todo o conhecimento e da impermanência de toda a percepção [ASCOTT, 1995].

\section{O ESPAÇO VIRTUAL NO DIGITAL}

Ciberespaço, digital, informático, numérico, virtual podem ser todos considerados sinônimos, embora possam ter aplicação específica para significar determinadas instâncias, mas será questão de opção adotar um ou outro termo. Para a definição de uma arquitetura do virtual, a designação digital será preferida, tomando para validá-la a indicação de Lévy, [1999: 45-75] de que o ciberespaço tem como matéria a tecnologia de informação de código binário, digital. O digital virtualiza as informações sendo, portanto, o fundamento técnico do virtual.

Tanto Julio Plaza [1991; 1998] quanto Lucrécia D'Aléssio Ferrara [1998] ao tratar da imagem virtual afirmam que o digital coloca em crise a função referencial da linguagem, conforme a definição das funções da linguagem realizada por Jakobson. Ampliando suas considerações para além da natureza da imagem, temos que o ciberespaço é auto-referente, inscrevendo-se no campo da linguagem que vai do simbólico ao icônico. O contexto onde se dá a criação da arquitetura, onde o pensamento se faz visível, tem como referente os modelos adotados e transformados em números que, traduzidos em imagens, possibilitam a simulação do projeto. 
É na dimensão do suporte, agora digital, que reside a grande mudança para o pensamento e a gênese da arquitetura do virtual. Este espaço heterodoxo, utópico e ucrônico solicita ao arquiteto desenvolver uma percepção que Ihe seja sensível, a ciberpercepção, no sentido de encontrar novas estratégias para continuar projetando uma arquitetura significativa para as interações da humanidade com o mundo que ultrapassem a mera relação utilitária [ASCOTT, 1995]. O traço distintivo do espaço digital está na perda da orientação ortogonal. A organização do espaço perde suas direções privilegiadas, o privilégio da vertical, em favor de um espaço onidirecional que está sempre variando seus ângulos e coordenadas. A tela do computador não é mais uma porta-janela (atrás da qual), nem um quadro-plano (no qual), mas uma superfície de informação sobre a qual deslizam dados. Perda que libera do falso problema da perspectiva [DELEUZE, 1990: 315; RAJCHMAN, 2000: 408].

Uma transformação imensa para a arquitetura, que exigiria dos arquitetos, pela primeira vez na história, projetar não simplesmente o objeto, mas seus princípios geradores e perceptivos [NOVAK, 1991: 251]. Se, como diz Rajchman, as tecnologias contribuem para determinar os campos de possíveis nos quais nos tornamos o que somos [RAJCHMAN, 2000: 405], o que importa para o pensamento é saber como e onde o digital se insere como virtualidade, como campo para a criação de possibilidades [RAJCHMAN, 2000: 400].

\section{O CONCEITO DE VIRTUAL}

Tarefa das mais complexas, definir o virtual. Principalmente porque é comum associá-lo à realidade, ao lugar comum da realidade virtual e seu conseqüente 
deslumbramento tecnológico, ou por oposição direta ao real. Contradição impensável entre admitir uma realidade que se define por seu par excludente e limitar sua condição fantasmática em posição antagônica à existência. Dupla confusão que apenas aumenta exponencialmente as dificuldades de definição. A realidade virtual deveria ser rebatizada de realidade simulada enquanto o real não se opõe ao virtual.

Segundo Pierre Lévy [1996], o virtual não se define pela oposição ao real. Virtual não é irreal, virtualizar não torna irreal. O virtual forma um par dinâmico com o atual e será preciso defini-los, um e outro, conjuntamente e em relação. E embora relacionado ao digital, que desempenha um papel preponderante nas transformações da cultura, o virtual ultrapassa amplamente a informatização das tecnologias [LÉVY, 1996: 11]. O virtual pode ser entendido como ferramenta de problematização no movimento do pensamento que reporta conceito e criação. Movimento que tende ao infinito ou finitovariável, na constância de sua dobragem sobre si, nos desdobramentos a partir de si. Criação problematizante que coincide com a emergência do novo [ALLIEZ, 2000: 11-18]. O pensamento que funciona por virtualizações se move entre complexidades e multiplicidades. É pensar como experimentação, sempre de outro modo, quando o pensamento se separa do saber e se torna curioso [RAJCHMAN, 2000: 397399].

É Bergson quem define o virtual como relativo ao espaço e ao tempo, por isso a relação com o atual, conceito posteriormente reinterpretado por Deleuze. Em seu Bergsonismo, Deleuze [1999: 39-56] descreve o conceito de virtual como relação do espaço e do tempo. Não um espaço 
que tem como referências linhas que convergem, quadro que recorta, plano de projeção, sobreposição de diagonais às coordenadas cartesianas para ordenar objetos, posicioná-los estaticamente, congelados no tempo. Ao contrário, virtual pressupõe durações, recorrências para trás, memórias, ocorrências para frente, possíveis, tempos em coexistência. Pressupõe movimento liberado de coordenadas, espaço de translações e rotações, de contrações e expansões, movimento constante das relações espaço e tempo.

"É assim que uma partícula atual emite e absorve virtuais mais ou menos próximos, de diferentes ordens. Eles são ditos virtuais à medida que sua emissão e absorção, sua criação e destruição acontecem num tempo menor do que o mínimo de tempo contínuo pensável, e à medida que essa brevidade os mantém, conseqüentemente, sob um princípio de incerteza ou indeterminação. Todo atual rodeia-se de círculos sempre renovados de virtualidades, cada um deles emitindo um outro, e todos rodeando e reagindo sobre o atual". [DELEUZE 1996: 49]

O atual é sempre presente, seu passado contemporâneo é virtual. Atual e virtual são avesso e direito, reversíveis um no outro, formando um curto-circuito. São distintos, mas não discerníveis, não param de se trocar e se prolongam no espaço e no tempo. Tempo que se desdobra a cada instante, presente que se desdobra em duas direções heterogêneas, passado e futuro. Um tempo não cronológico [DELEUZE, 1990: 87-104].

"A distinção entre atual e virtual corresponde à cisão mais fundamental do tempo, quando ele avança diferenciando-se em duas grandes vias: fazer passar o presente e conservar o passado. O presente é um dado variável medido por um tempo contínuo, isto é, por um suposto movimento numa única direção: o presente passa à medida que esse tempo se esgota. É o presente 
que passa que define o atual. Mas o virtual aparece por seu lado num tempo menor do que aquele que mede o mínimo de movimento numa direção única. Eis porque o virtual é efêmero. Mas é também no virtual que o passado se conserva, já que o efêmero não cessa de continuar no 'menor' seguinte, que remete a uma mudança de direção." [DELEUZE 1996: 54-55]

O virtual, a tendência da virtualização de todas as esferas da vida é desterritorializante, pois força a atualidade a enfrentar uma dinâmica mutante feita de questões gerais que redefinem a particularidade de partida. O virtual é uma desterritorialização que consiste, antes de tudo em reduzir a atualidade inicial em caso particular de um problema geral sobre o qual se coloca o acento ontológico. Assim, o virtual dilui as distinções, aumenta os graus de liberdade, cava um vazio motor [ALLIEZ, 1996: 1314].

\section{A NATUREZA NUMÉRICA DO DIGITAL}

É preciso não esquecer que o espaço operacional de ação do virtual é o digital, seu fundamento material, embora instável e mutante nas oscilações e combinações entre 0 e 1 . O número como matéria digital se coloca em outra dimensão, virtual, na intersecção entre a simulação e a interatividade [RAJCHMAN, 2000: 406]. O epíteto virtual atribuído ao numérico digital qualifica o conjunto de cálculos que estão em sua origem, caracterizando a simulação, uma interpretação do real formalizada em modelo lógico matemático [COUCHOT, 2003: 175-176]. Como diz Deleuze, os números sempre serviram para dominar a matéria e controlar suas variações e seus movimentos [DELEUZE e GUATTARI, 1997b: 64]. 
Segundo Julio Plaza, no espaço do digital, o número exerce três funções: transdução, paramorfismo e otimização. $\mathrm{Na}$ transdução, a informação numérica passa a tomar uma forma, do simbólico ao icônico, mantendo a invariância na equivalência, suas relações e conexões internas se imprimem na sintaxe de configuração. No paramorfismo, a combinação numérica é reversível, possibilitando a conversão de um signo em outro, sendo dele equivalente. O número é referência e diferença. Na otimização, o número funciona faz ajustes no processo para obter sempre os melhores resultados, operando na organização do espaço e das formas [PLAZA, 1998: 27-28]

Nesse contexto numérico, de simulação sobre a linguagem, o projeto de arquitetura se encontra no terreno da experimentação, das combinações instantâneas, dos lugares deslocados, dos dígitos em relações definidas por sistemas. Os modelos tridimensionais digitais são explorados de modo interativo pois sua natureza é plástica, dinâmica, agindo e reagindo conforme o desenrolar da simulação [LÉVY, 1993: 121]. O significado do projeto é inerente ao próprio fazer, na medida ativa da capacidade projetiva, que associa, experimenta, descobre, procurando a solução de problemas virtuais [FERRARA, 1998: 8-9].

\section{MÁQUINA CONCEITUAL DE EXPERIMENTAÇÃO}

Se o computador é essa máquina que congrega pensamentos, que é agenciamento, articulação de pensamentos diversos, que antes dispersos, convergem como constituintes da tecnologia numérico-digital, é preciso tecer uma definição que se aproxime dessa condição, que possa exprimir sua complexidade como tecnologia, ciência e pensamento.

Como diz a filosofia, como máquina que congrega, põe em 
relação todas essas dimensões e que dependem de agenciamentos para operar.

O computador materializa uma tecnologia que agrega a técnica, saber-fazer ao pensamento, saber científico, numa síntese tal qual linguagem, produtora da cultura, instaurando uma prática da simulação, da experimentação de informações sobre a linguagem [PLAZA, 1991: 7]. Experimentar é pensar, é o que está em processo, sem começo nem fim, mas que precisa ter apoio numa determinada história provedora de sentido. A experimentação é filosófica [DELEUZE e GUATTARI, 1992: 143]. Pensar é experimentar com conceitos (filosofia), ou com prospectos (ciência) ou ainda com perceptos (arte), cada caso submetendo a linguagem de modo incomparável, tecendo cruzamentos, entrelaçamentos, que não definem diferenças nem promovem identificações. O filósofo trata de variações, o cientista de variáveis, o artista de variedades [DELEUZE e GUATTARI, 1992].

Desse modo, será preciso recorrer à filosofia para, num movimento contínuo sobre variações, construir uma possível definição da tecnologia digital, do computador numérico, da máquina informática, sempre com a visão voltada para sua relação processual com a criação da arquitetura como pensamento e objeto. E a filosofia de Deleuze e Guattari se apresenta como possível caminho de leitura. Nela se encontram três conceitos que, fruto da leitura amplificada da cultura, parecem ser fundamentais também para a compreensão do digital como sintoma e manifestação de uma condição cultural: diagrama, dobra e virtual. Conceitos que investem o pensamento maquínico sobre o mundo e suas realizações, sobre a própria filosofia, sobre a ciência que os traduz em funções e sobre a arte que os traduz em linguagens. 
A informática, o maquínico, o digital redimensiona o domínio da arquitetura, transformando o ato projetivo, segundo Lucrécia D'Aléssio Ferrara, em reflexão simultânea sobre experimentações e simulações das idéias em processo. Essa informação interativa em regime dialógico é pensamento sobre a natureza do espaço e da arquitetura:

"Revela-se a arquitetura como domínio da linguagem; como produtora da cultura enquanto propõe, por meio do projeto, outros usos, outras informações no espaço. (...) A arquitetura é signo da concepção do espaço. (...) Como linguagem, a arquitetura é representação, é signo da relação de conhecimento que se processa entre o espaço e o homem que sobre ele intervém, por meio do projeto ou do uso cotidiano" [FERRARA, 2000: 155-156]. 
Capítulo 4

\section{experimentação e descoberta}

entre diagramações, desdobramentos e virtualidades

4.1 diagrama da arquitetura maquínica

4.2 desdobramentos analógico-digitais

4.3 arquitetura no espaço da virtualidade 
132 
Segundo Somol [1999: 7-12], a partir da segunda metade do século XX é possível identificar uma mudança na maneira de pensar a arquitetura que se revela pela mudança do procedimento fundamental para projetar, que passa do desenho para o diagrama. Desenho segundo Argan [2001: 54-55], como técnica de ideação, princípio ideal, desenho que já é projeto, ao passo que o diagrama, ainda que também um desenho, difere deste por ser aberto, indicando inúmeras possibilidades. Se o procedimento muda deve se encontrar os materiais adequados para realizar uma arquitetura que seja também outra. Se o diagrama assume o lugar do desenho como pensamento da arquitetura, como realizar tal pensamento, como processá-lo como linguagem?

Para Peirce, o diagrama é um signo relacional, campo de possibilidades, que, segundo Guattari, o assimilava à função do algoritmo [GUATTARI, 1992: 57]. Na verdade é o Panoptismo de Foucault [1987:162-192] que define o diagrama como conceito da dimensão informal da tecnologia. O Panóptico de Bentham é um aparelho arquitetural que dissocia o ver e o ser visto, uma máquina que sustenta uma relação de poder independente de quem o exerce. O poder se exerce por si, no espaço. Assim, diagrama informal é também máquina abstrata, máquina social antes de ser técnica, tecnologia humana antes de se materializar em coisa [DELEUZE, 1998: 64-65]. Como no caso da arquitetura, nem toda máquina é ótica, mas pode fazer ver, traz algo à luz, faz surgir visibilidades [DELEUZE, 1998: 85].

Partindo de Foucault as definições de máquina e diagrama feitas por Deleuze e Guattari são convergentes, originando o 
conceito de pensamento diagramático ou maquínico. Entre os mil platôs da filosofia as definições de um e outro se encontram dispersas. O diagrama:

"é profundamente instável ou fluente, misturando incessantemente matérias e funções de maneira a constituir mutações. (...) todo diagrama está em devir. (...) Ele faz a história desfazendo as realidades e as significações antecedentes, constituindo outros tantos pontos de emergência ou de criatividade, outras tantas conjunções inesperadas, outros tantos contínuos improváveis. Ele duplica a história com um devir". [DELEUZE, 1998: 59-60].

Já a máquina abstrata:

"é muito mais do que a linguagem. A máquina abstrata não tem forma em si mesma (...) e não distingue em si conteúdo ou expressão. (...) Uma máquina abstrata em si não é mais física ou corpórea do que semiótica, ela é diagramática. (...) A máquina abstrata é a pura Função-Matéria - o diagrama, independentemente das formas e das substâncias, das expressões e dos conteúdos que irá repartir. (...) A matéria é uma substância não-formada, física ou semioticamente". [DELEUZE e GUATTARI, 1995: 99].

O diagrama existe a cada vez que uma máquina abstrata singular age diretamente sobre uma matéria [DELEUZE e GUATTARI, 1995: 101]. O conceito é auto-referencial, põe-se a si mesmo e gera seu objeto, ao mesmo tempo em que se cria [DELEUZE e GUATTARI, 1992: 34]. Mas não se trata de reunir tudo em torno de um mesmo conceito, toda a arquitetura sob as mesmas articulações, mas ao contrário, de referir cada conceito, cada projeto, a variáveis que lhe determine as mutações [DELEUZE, 1992: 44].

Se há uma máquina de arquitetura ela contém regras prévias que, no entanto não são deterministas, mas conduzem 
a possíveis estados, algo como um espaço em constante transformação, que poderia ter uma direção ou tratar de uma energia, de forças ou fluxos, num processo iterativo, porém singular. Uma arquitetura em estado de devir [EISENMAN, 1997]. Assim como a máquina abstrata, a arquitetura maquínica constrói um real por vir, um novo tipo de realidade, está "antes" da história [DELEUZE e GUATTARI, 1995: 100]. E toda nova arquitetura precisa de formas revolucionárias [DELEUZE, 1992: 196]. Nas palavras de Deleuze e Guattari:

"O artista cria blocos de perceptos e de afectos, mas a única lei da criação é que o composto deve ficar de pé sozinho. O mais difícil é que o artista o faça manter-se de pé sozinho. Para isso, é preciso por vezes muita inverossimilhança geométrica, imperfeição física, anomalia orgânica, do ponto de vista de um modelo suposto". [DELEUZE e GUATTARI, 1992: 214].

\section{AS MOTIVAÇÕES DE UM PROJETO}

Desde a metade do século XIX, mudanças significativas afetaram a ciência e a filosofia, transformando o pensamento e a conceituação do homem e do mundo. Contudo, essas transformações não causaram efeitos pouco perceptíveis na arquitetura. Enquanto a ciência e a filosofia questionam seus fundamentos e assistem à dissolução de suas fundações, a arquitetura permanece reafirmando o discurso clássico. Arquitetos não questionam o aqui e agora, não refletem sobre a gravidade como os cientistas e os filósofos. Arquitetos constroem o aqui e agora lidando com a real condição da gravidade. Eles edificam uma presença física que tem como objetivo superar de fato a natureza. Por que a arquitetura tem tanta dificuldade em questionar seus princípios fundamentais? A resposta pode ser que a essência da arquitetura é locar, localizar e assim seria a disciplina com mais dificuldade para se deslocar. [EISENMAN, 1989a; 1989b] 
A tradição humanista da arquitetura é caracterizada pelo equilíbrio entre o programa e a maneira pela qual este se materializa e a articulação de temas ideais a priori na construção, os significados atribuídos. Materialização do programa e articulação de temas, dois termos da experiência contínua investida pela visão idealista do homem como centro desta mesma experiência. A industrialização da arquitetura perturba o equilíbrio dessa continuidade transformando a função em programa cada vez mais complexo e a forma se vê diminuída em suas realizações. Forma e função que legitimam a arquitetura moderna e funcionalista é nada mais do que a continuação do humanismo como manifestação estilística, o funcionalismo.

O projeto utópico encarnado pelo movimento moderno não foi capaz de realizar a revisão necessária dos cânones do clássico, permanecendo como prolongamento daquele pensamento. A modernidade revela uma sensibilidade calcada na mudança de atitude mental em relação ao mundo que se manifesta numa outra postura cultural, decalcada em manifestações de várias disciplinas. Nas artes, a música atonal, a pintura abstrata e as narrativas atemporais seriam alguns exemplos, representações sintomáticas do deslocamento do homem de sua condição de centro do mundo, da dissolução da idéia de sujeito [EISENMAN, 1976].

Os parágrafos precedentes procuram sintetizar algumas das principais motivações de Peter Eisenman, em sua busca por realizar uma arquitetura sintonizada com as questões da cultura contemporânea. Compreendê-lo é tarefa das mais difíceis, uma vez que suas idéias são inúmeras, materializadas e manifestadas em textos e obras de difícil leitura. Suas referências são incontáveis, indo da lingüística à genética, da 
história da arquitetura à filosofia, da física à psicanálise

[JENCKS, 1997: p.139]. Suas declarações são polêmicas, suas obras controversas. Contudo, talvez nenhum outro arquiteto contemporâneo tenha um projeto tão claro e definido como ele, o que poderia ter o nome de projeto Eisenman.

E se há uma relação entre Eisenman e as vanguardas construtivas, está muito além da reinterpretação de suas obras fundamentais. A relação é intencional, conceitual e tem por objetivo fazer com que a arquitetura realize de fato a experiência da vanguarda que não foi capaz de realizar plenamente. Engajado nessa passagem, Eisenman parece recuperar o formalismo russo, o priom, a dinamicidade do par material e procedimento [TAFURI, 1984: 447-450; 1976: 47-48].

Integrante de uma geração de arquitetos americanos, da qual fazem parte, entre outros, Richard Meier e John Hejduk (que junto com Michael Graves, Charles Gwathmey/Robert Siegel e o próprio Eisenman constituiram o grupo novaiorquino Five Architects), Robert Venturi e Frank Gehry, formados entre o final dos anos 50 e o início dos anos 60, pode-se dizer que recebem uma formação bastante peculiar. Quatro pontos podem ser ressaltados. Primeiro, estão sob a influência e a presença dos mestres modernos emigrados da Europa do segundo pós-guerra: Corbusier e Gropius estão em Harvard, Mies está em Chicago, Breuer está em Nova lorque, todos de alguma maneira envolvidos com o ensino. Segundo, o grande arquiteto americano do segundo pós-guerra e professor de muitos arquitetos da nova geração é Louis Kahn, que propõe uma inversão de valor no par forma e função, postulando uma arquitetura formulada a partir da fricção entre forma, geometria e design, o desempenho funcional da forma. Terceiro, apesar do centro geográfico da cultura ter se deslocado do continente 
europeu para o território norte-americano, há nos anos 50 e 60 uma certa recessão construtiva no país que leva forçosamente os jovens arquitetos à prática acadêmica. [MONTANER, 1993: 167-175] E por fim, estão sob a influência da declaração do fim da arquitetura moderna feita por Philip Johnson, também professor de muitos:

"Só há uma coisa absoluta hoje: a mudança. Não há regras nem certezas (...) apenas infinitas possibilidades e um passado ilimitado de grandes arquiteturas a serem exploradas. Longa vida à Mudança!" [PORTOGHESI, 2002: 68]

Assim, a proximidade com os formuladores do projeto moderno, a abordagem alternativa da forma, a necessidade de reflexão teórica e o proclamado fim da arquitetura moderna vão possibilitar que Eisenman se transforme num dos principais protagonistas da arquitetura contemporânea a partir dos anos 70. Nas décadas seguintes, o arquiteto terá um papel importante nas transformações da disciplina, no mais das vezes pressentido de modo negativo. São correntes as definições de sua obra como anacrônica e frívola [ROWE, 1972], maneirista e esvaziada de sentido [FRAMPTON, 1972]. Além disso, as relações que estabelece entre a arquitetura e outras disciplinas, como fez com a desconstrução de Jacques Derrida, são freqüentemente encaradas como gratuidade e modismo. É preciso ter cuidado com as interpretações superficiais e incompletas de sua obra, que dificultam alcançar sua complexidade. Sua arquitetura não é simplesmente uma reinterpretação da arquitetura moderna, nem se resume a um procedimento formalista arbitrário, muito menos ao mero exercício puramente retórico [PORTOGHESI, 2002: 121-123]. A arquitetura de Eisenman é, antes de tudo pensamento e conceito que pretende se inscrever como transgressão e negação, linguagem e investigação. Sua obra revela a intenção 
fundamental de realizar uma arquitetura sintonizada com as questões da atualidade.

\section{MÁQUINA DE ARQUITETAR: PETER EISENMAN}

Para realizar o propósito de seu projeto, o arquiteto procura o sentido próprio da arquitetura, aquilo que lhe é inerente, despida dos significados atribuídos. Eisenman quer encontrar a interioridade da arquitetura. Para tanto, é preciso desviar da continuidade da tradição clássica e negar os postulados da vanguarda arquitetônica dos primeiros anos do século XX. É necessário transgredir a tradição, baseada na tríade utilitas, firmitas, venustas de Vitruvio. Comodidade, firmeza e deleite, uso, estrutura e beleza, não são atributos que servem para qualificar apenas a arquitetura tradicional, mas sim termos que continuam dando sentido e legitimando a arquitetura segundo a tradição. Trazem consigo um determinado significado que está além de sua função, impregnado em sua imagem. Uma estrutura não deve apenas funcionar como tal, mas deve parecer estrutural. O caráter estrutural deve ser legitimado pela representação icônica do ficar em pé, do sustentar. A arquitetura está, desse modo, subordinada por leis de semelhança e utilidade à dimensão semântica da função que precede e define a forma [EISENMAN, 1997].

A tradição estende seu manto sobre os ideais do movimento moderno transformando-o num projeto utópico, sem lugar, irrealizado. Sua identidade com a idéia de mudança causa a impressão de revolução permanente, contudo, seu modo de especulação é histórico ao invés de lógico [EISENMAN Apud TAFURI, 1976: 45]. Além disso, a oposição da forma à função ou a submissão da primeira pela segunda, 
forma segue função, característica fundamental da arquitetura moderna, não é condição inerente a toda teoria ou prática da arquitetura. Não basta apenas fazer uma revisão do ideário moderno, de suas realizações e de seus ideais sociais, mas é preciso negá-lo postulando sua evolução. Se o moderno revela uma outra sensibilidade baseada no reconhecimento da dissolução do papel central do sujeito, a arquitetura não foi capaz de realizá-lo. Portanto não se pode negar a modernidade, o que se deve negar é o funcionalismo. No lugar de pós-moderno, pós-funcionalismo.

"Modernismo, como sensibilidade baseada no deslocamento do sujeito, representa o que Michel Foucault especificaria como nova epistême. Derivando de uma atitude não humanista frente à relação do indivíduo com o meio físico, rompe com o passado histórico, tanto no modo de considerar o homem como sujeito quanto no positivismo ético da forma e função. Portanto, não há relação com o funcionalismo. Talvez por essa razão o modernismo só agora esteja sendo elaborado pela arquitetura". [EISENMAN, 1976: s/n]

Liberada da condicionante funcionalidade semântica, a arquitetura pode encontrar suas bases sintáticas. Segundo Eisenman, essa autonomia formal da arquitetura tem dois modos de realizar, que devem ser confrontados. Um, humanista, em que a forma pode ser considerada como derivação de sólidos platônicos, forma que se engendra através de uma série de registros, o projeto como processo para encontrar tal geometria. Outro, moderno, considera a forma como conjunto de fragmentos, constituída por entidades espaciais, signos desprovidos de significado. Os dois modos de formar, juntos, definem a natureza inerente ao objeto e sua capacidade intrínseca de representar a si mesmo. [EISENMAN, 1976] 
Essa afirmação formalista dos procedimentos sintáticos pode parecer traição aos ideais éticos e sociais do movimento moderno. Mas a guerra já estava terminada e com ela a esperança de realizar aqueles ideais. A ênfase na sintaxe pode sugerir que a arquitetura se reduz à experimentação teórica, de manipulação retórica [TAFURI, 1976: 57]. Entretanto, a possibilidade da existência da postura crítica reside na experimentação em oposição à produção da arquitetura. Experimentação como investigação conseqüente, carregada de intencionalidade, a fim de trazer à luz o que estava reprimido pelas convenções que confinava à função a potencialidade da forma. [EISENMAN, 1997: 15-18]

\section{A SINTAXE DO PÓS-FUNCIONALISMO}

Em As palavras e as coisas, Foucault [2002] dizia que ao longo do século XIX a literatura havia encontrado sua autonomia, constituindo um contra discurso baseado numa evolução que não reconhecia origem, não encerrava nenhuma promessa, não previa percurso ou destino. Lá é onde se manifesta o ser da linguagem [FOUCAULT, 2002: 58-61]. À questão que aparece no Ecce homo, (que tem como subtítulo como alguém se torna o que é), colocada por Nietzsche: 'quem fala?', que sujeito é esse? Mallarmé responde: ‘a própria palavra', ou seja, a linguagem [FOUCAULT, 2002: 417-423].

O postulado do pós-funcionalismo abre o campo da arquitetura para a elaboração de sintaxes formais, ao propor um novo lugar para o sujeito, autor e usuário. Eisenman procura estabelecer uma linguagem através da qual seja possível a articulação de elementos, despidos de todo o significado atribuído. Assim, sacrifica não só o funcionalismo, mas também o humanismo, uma vez que a subjetividade das significações 
também se apaga. A referência fundamental para realizar tal operação é a lingüística. Os elementos são transformados em entidades abstratas - planos, linhas, são signos que só ganham sentido na inter-relação com os outros signos, são valores relacionais, que só adquirem significado na articulação da sintaxe, quando ocupam uma posição no sistema formal.

Contudo, não é a lingüística de Saussure [1970], raiz do estruturalismo que serve de material para Eisenman, mas a sintaxe de Chomski [1957] que permitirá ao arquiteto gerar sistemas de relação baseados em estruturas sintáticas. A sintaxe de Chomsky não é auto-referente de maneira estrita. Pressupõe um sujeito dotado de conhecimento pertinente à estrutura sintática, capaz de articular e combinar, gerando possibilidades. Passa-se das regras estáticas estruturalistas para a capacidade heurística do sujeito, operador qualificado que conhece a linguagem e inventa a sintaxe. Não por acaso, um dos principais interlocutores de Eisemnan seria Derrida e sua desconstrução como implosão de toda a percepção hegemônica e logocêntrica do homem e das suas obras [FERRARA, 2002:159].

Eisenman coloca a arquitetura, seu projeto e processos de formar, numa base sintática que permita construir objetos singulares, formas novas que provoquem percepções singulares. Singularidade como base da atividade experimental em que se transforma o projeto. Em seu eminente ensaio $A$ obra de arte na era de sua reprodutibilidade técnica, Walter Benjamim [1985: 192-194] define a arquitetura como modelo para recepção distraída, definida pela dupla recepção, por meio do hábito tátil conjugado à percepção ótica, determinada em grande medida pelo uso. Se Benjamim previa, então, que a dominância do tátil possibilitaria uma revolução pelos sentidos, 
seu triunfo, como se seguiu, no domínio do ótico, da imagem, mostrou ser tudo menos revolucionário [ARANTES, 1993: 2028]. A distração como condição de recepção da arquitetura deve ser reinterpretada. Para o arquiteto, a fonte da distração e do hábito é a geometria cartesiana que organiza o espaço, a estrutura, a forma, sendo, portanto inadequada para pensar o espaço arquitetônico [EISENMAN, 1997: 14-15]. As visões devem se desdobrar pela provocação do estranhamento, pela dificuldade de recepção que qualifica a percepção, transformando a arquitetura em espaço de confronto, em forma difícil, linguagem em processo. Uma arquitetura para representar o sujeito descentrado, alijado do programa conhecido e colocado na situação da dúvida [ARANTES, 1993: 82].

\section{AS BASES FORMAIS DA ARQUITETURA}

A arquitetura pós-funcionalista considera a forma na sua capacidade sintática de revelar seu próprio significado, que, intransitivo, provém dos procedimentos sintáticos adotados, da interioridade da própria arquitetura que fala sobre si mesma. Eisenman constata que um sistema formal completo regido por regras finitas e específicas, como o existente na música ou como na referência lingüística, nunca existiu. As regras em arquitetura são transitórias, facultativas, não mandatórias e os arquitetos costumam trabalhar com fragmentos de sistemas de regras formais, raramente articulados sob uma lógica global. Por exemplo, a casa, além do abrigo, pode ser compreendida como articulação de elementos que oferecem uma gradação entre público e privado, conectados em seqüência que vai do público estrito, a porta da rua, ao puramente privado, respeitando a lógica das convenções sociais e culturais. A unidade, o edifício se dá através da sobreposição de vários 
sistemas parciais, com suas regras e sintaxes próprias:

construtivo, proporcional, circulação [GANDELSONAS, 1982].

A preocupação de Eisenman com a questão da forma e a necessidade de formular uma teoria que sustentasse uma nova abordagem da prática do projeto e da arquitetura, aparece desde de sua tese As bases formais da arquitetura moderna, em 1963. Suas referências mais imediatas são a análise das vilas de Palladio realizadas por Rudolph Wittkower [1958] em A arquitetura na idade do humanismo e a elaboração posterior dessa análise que compara Le Corbusier a Palladio, conforme mostrada por Colin Rowe [1982] em As matemáticas da vila ideal, ambas publicadas no final dos anos 40. Em comum, essas duas análises recorrem a diagramas como recurso para demonstração. É preciso lembrar ainda, como diz Somol, que as Notas sobre a síntese da forma de Christopher Alexander [1969] traz a afirmação de que sua contribuição mais significativa é a idéia do diagrama. [SOMOL, 1999: 7-8].

Procurando articular os princípios formais da arquitetura, Wittkower aplica um diagrama sobre a geometria, Rowe os utiliza para explicar paradigmas e Alexander os define como padrões. Wittkower faz uma análise geométrica das plantas das vilas de Palladio e detecta a presença de regras sintáticas nesses projetos, traduzidas em diagramas de nove quadrados. Rowe realiza interpretações partindo da constituição formal da arquitetura através de comparações diacrônicas e o posterior estabelecimento das diferenças entre os projetos estudados. A aproximação de Corbusier e Palladio identifica similaridades entre modos de formalizar o projeto e diferenças na articulação da sintaxe: Palladio procura a centralidade e Corbusier a dispersão. A análise mostra que os projetos partem de uma 
armadura ideal de organização do espaço baseada em um quadrado dividido em nove partes.

As vilas de Palladio se transformam através dos diagramas de Wittkower e Rowe, em macro unidades que permitem a pesquisa formal para o estabelecimento de um domínio sintático, onde a forma se transforma enquanto o significado permanece inalterado [GANDELSONAS, 1982]. Contudo, tão importante quanto a leitura formal realizada por Rowe que aponta a possibilidade de descolamento entre estrutura e espaço, função e forma, é o papel tomado pelo dispositivo de análise. O diagrama dos nove quadrados, que

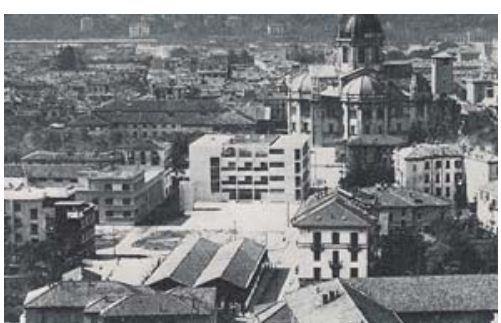

48. Vista da situação

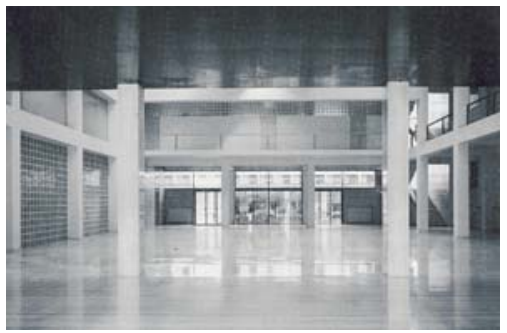

49. Terragni: interior permite articular relações plásticas e formais, tornou-se um recurso pedagógico largamente adotado por diversas escolas de arquitetura norte-americanas nos anos 50 e 60 [EISENMAN, 1999: 27]. No lugar do programa funcional como partido, coloca-se o projeto numa base sintática de articulações lógicas e conceituais de pares como centro/periferia, vertical/horizontal, dentro/fora, cheio/vazio, frontalidade/rotação, que definem a arquitetura como linguagem [SOMOL, 1999: 10-14].

Essa mudança do domínio semântico para o sintático, da função para a relação, da estrutura para a forma como sistema, se expressa desde as primeiras obras de Eisenman. Sua produção teórica reflete a consistência de seu projeto. $\mathrm{Na}$ análise que faz da Casa Del Fascio em Como, de Giuseppe Terragni [EISENMAN, 1970], afirma ser necessário passar o foco do objeto para a relação. Segundo ele, em Como, Terragni teria feito uma obra de invenção, com regras próprias baseadas na autonomia do plano. O espaço se organiza a partir do plano frontal, de modo recessivo, por uma série de relações sintáticas intrínsecas, tornadas visíveis. A leitura do projeto de James Stirling [EISENMAN, 1974] para o Laboratório de Engenharia da 
Universidade de Leicester permite reconhecer o pensamento arquitetônico como jogo formal de volumes, apontando para a continuidade da evolução da arquitetura. A autonomia do plano como elemento formal, as relações sintáticas reveladas na obra, a afirmação da evolução da forma arquitetônica, são descobertas importantes para definir aquilo que Eisenman chamou de auto-referência da arquitetura. A estrutura dominó de Corbusier seria a expressão máxima dessa arquitetura relacional, hipótese diagramática para toda a arquitetura moderna [EISENMAN, 1979].

\section{O DIAGRAMA DAS CASAS I - X}

Eisenman inicia sua atividade de projeto com uma série de casas numeradas que funcionam como uma espécie de laboratório teórico-prático para aplicação de um processo de criação diagramático. E o caráter de laboratório se afirma pela inversão adotada no processo, em que o resultado final não tem maior importância do que as etapas de concepção do projeto. As etapas do processo lançam mão de diagramas, desenhos e modelos tridimensionais considerados como sendo a realização da arquitetura, pois são expressões do pensamento que a concebe. É fácil compreender porque essa arquitetura ficou conhecida como arquitetura de papel cartão.

Ao identificar Eisenman a certas margens da arquitetura que procura seu lugar depois dos modernos, Otília Arantes [1993: 65-70; 74-92] observou que nas casas de papel cartão o objeto final não é síntese, mas uma interrupção na sucessão de investidas experimentais, o que determina a precedência do percurso sobre resultado. As casas são signos de si próprias, que continuamente se processam voltando sobre si mesmas. Assim, o processo de criação tradicional é pervertido e o objeto

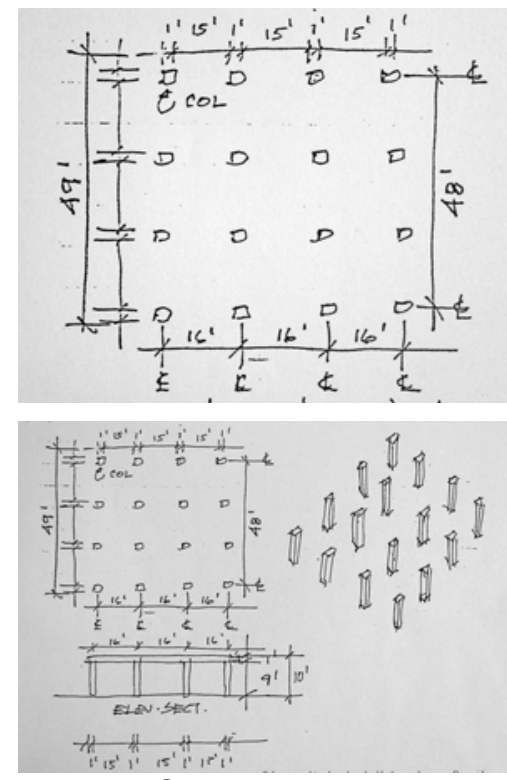

50 e 51 . O diagrama dos 9 quadrados, conforme John Hejduk. 


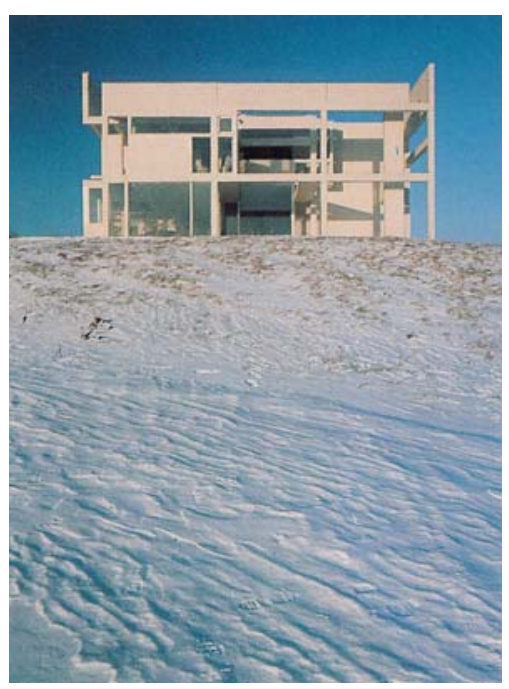

52. Casa II de Eisenman e as margens da arquitetura: 'isto não é uma casa'. final não é mais o resultado lógico, mas é a extensão do pensamento que se espalha por diversas representações. $O$ desenho não mais anuncia a obra, é a obra que representa o desenho. Nas casas de Eisenman ressoa um eco de Magritte: "Isto não é uma casa".

É quase impossível fazer uma leitura de qualquer uma dessas casas isoladamente, pois cada uma se reporta às outras, a segunda à primeira, a décima a todas as anteriores, formando um sistema relacional em que as partes só adquirem sentido na sua inter-relação. Cada casa e o conjunto que constituem obedecem à mesma lógica sintática de organização do espaço e assim uma única definição serve para descrever a complexidade do todo e das partes. Os elementos, as formas (planos, linhas, ou cada casa) são sinais que ganham sentido na relação com os outros sinais, são valores relacionais que adquirem significado na articulação da sintaxe, quando ocupam uma posição no sistema formal. A cada etapa do processo, cada forma ganha um significado sintático, na inter-relação com as demais. O objetivo é alcançar um conjunto de formas, de objetos que constituam uma unidade, dotadas de significados vinculados à interioridade da própria operação arquitetônica [GANDELSONAS, 1982: 7-31].

\section{PROGRESSÃO DE I A IV e DESVIO EM VI}

As quatro primeiras casas adotam de forma integral o diagrama dos nove quadrados, sobre o qual são sobrepostas outras questões definidas de antemão, a interioridade da arquitetura, representadas diagramaticamente. Elas são organizadas a partir de transformações lineares de elementos pré-existentes que partem de A para B seguindo um processo racional. Na Casa I (1968-69) a procura por novos diagramas a 
partir dos primeiros teve uma função também retrospectiva. A Casa II (1969-70) foi pensada a partir da duplicação do sistema estrutural, paredes auto-portantes e malha de pilares concorrendo no espaço, produzindo um excesso. Os dois sistemas receberam valores iguais, portanto qualquer dos dois poderia ser visto como excesso. A Casa III (1969) procura tirar do foco o sistema hierárquico entre os elementos construtivos e a Casa IV (1971) adota um diagrama sistêmico em que cada movimento é resposta ao precedente e assim se ajusta em meio às várias alternativas.

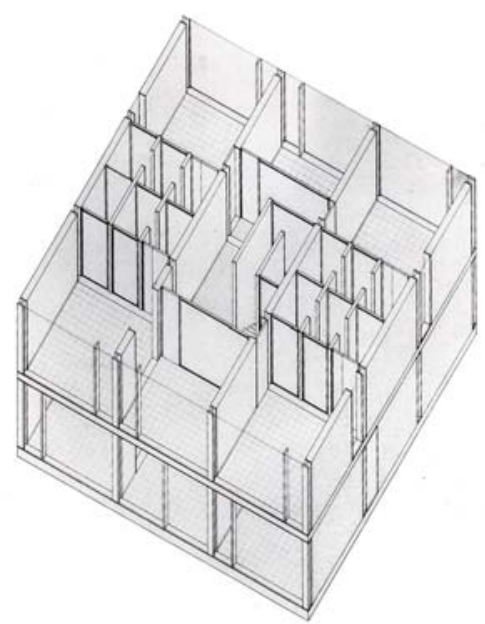

53. Hejduk: Texas House 1

Outro arquiteto que utilizou com bastante intensidade o diagrama dos nove quadrados foi John Hejduk. Integrante dos Five de Nova Iorque, Hejduk aplicava os diagramas em suas aulas de projeto na Universidade do Texas em Austin, desde 1954, data em que iniciou pesquisa através de uma série de projetos conhecida como Texas Houses que se alongou até os anos 70 [HEJDUK, 1985: 37-41; SOMOL, 1999: 12-17]. As obras das vanguardas artísticas são referência direta em seu trabalho, como as obras do De Stijl, o que pode levar à compreensão superficial de que suas obras são trabalhos eminentemente sobre imagens, caso da inversão do quadrado a $45^{\circ}$ como em Mondrian. Mas Hejduk também adota alguns conceitos fundamentais, partilhados por Eisenman, como a utilização das projeções paralelas, axonométricas e isométricas, também utilizadas pelo De Stijl, especialmente por Theo Van Doesburg, como dispositivo para representar a autonomia do objeto liberado do ponto de vista único e central do sujeito aprisionado na certeza salvadora. [HEJDUK, 1984: 86-88; SOMOL, 1999: 17-18]

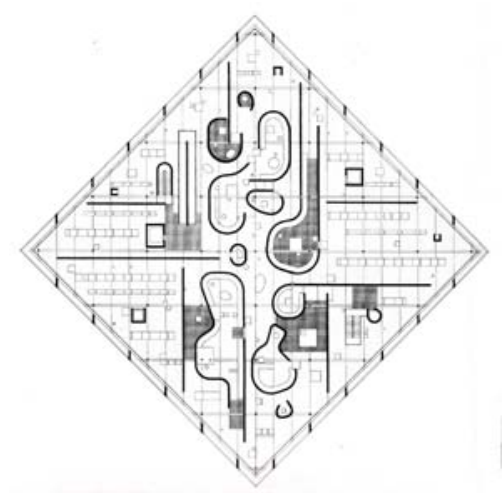

54. Hejduk: Diamond Museum 


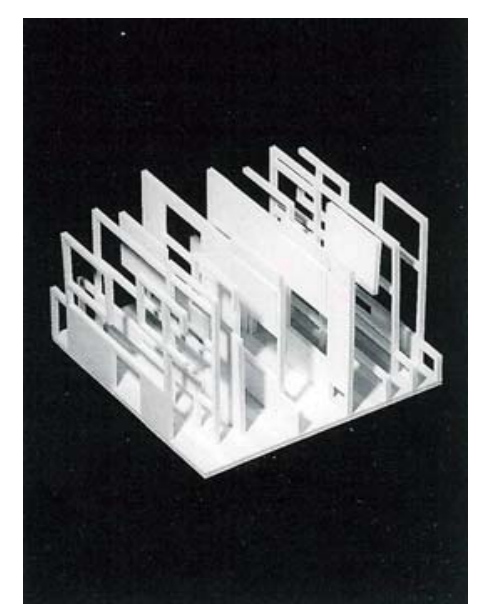

62. Casa IV: modelo de estudo
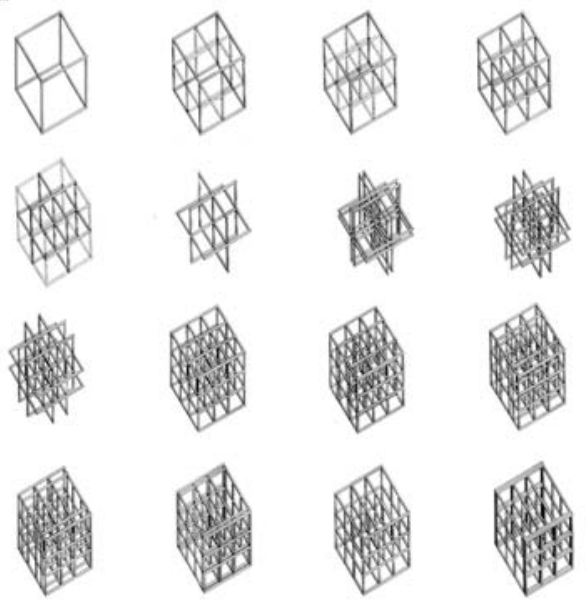

61. Casa IV: diagramas

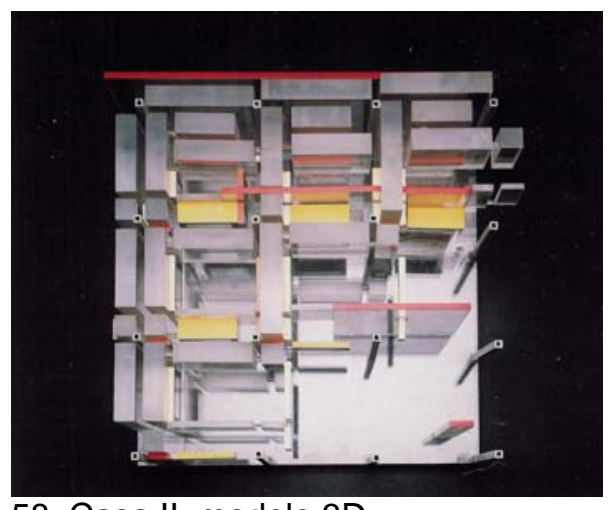

58. Casa II: modelo 3D

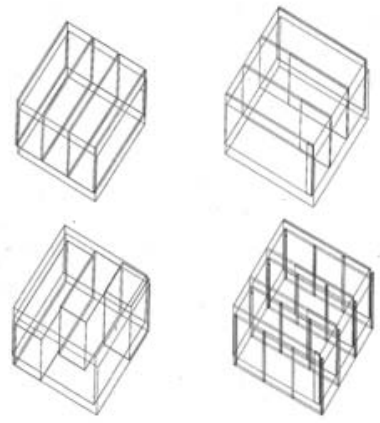

57. Casa II: diagramas

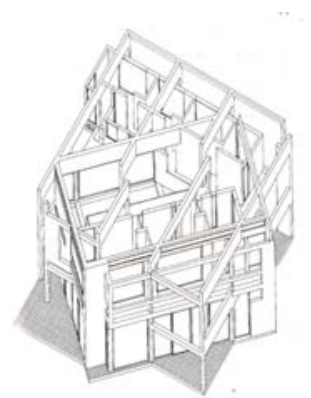

59. Casa III: diagramas

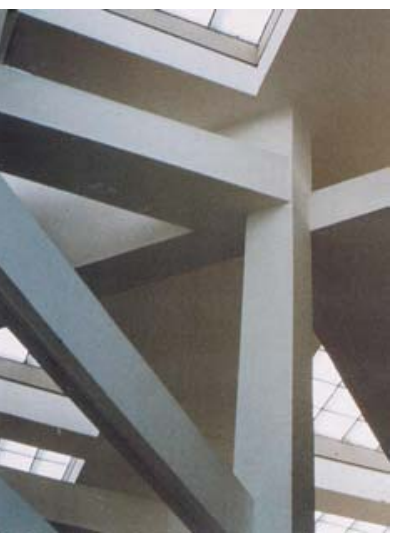

60. Casa III: estrutura

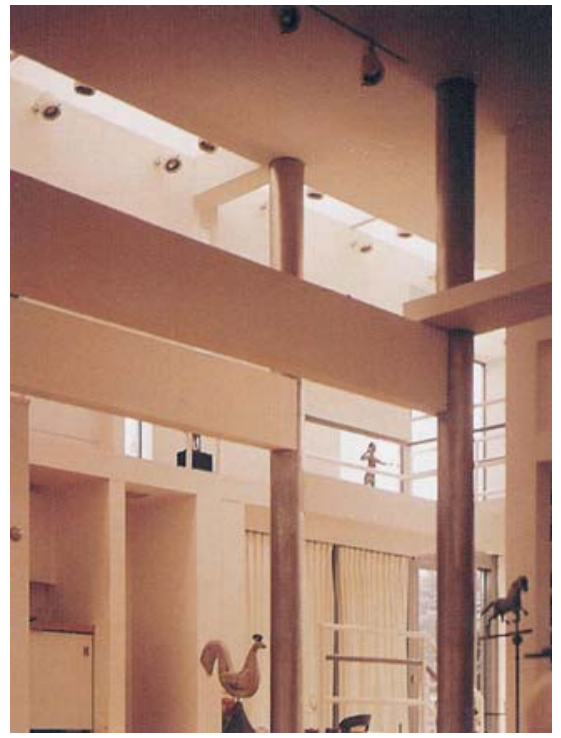

56. Casa I: interior

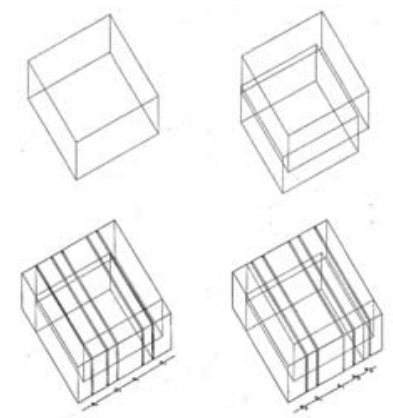

55. Casa I: diagramas

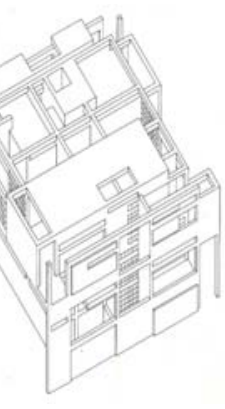

Na Casa VI (1972-75) o diagrama se faz como processo. Surge a cor como notação de qualidades espaciais como cheio, vazio, aberto, etc. com a intenção de remeter à possível experiência do espaço. Eixos demarcam o espaço diagonalmente, de cima para baixo e vice-versa e apóiam duas escadas inversas e assimétricas no espaço. As coordenadas do espaço euclidiano são quebradas, criando um espaço topológico sem orientação definida. As superfícies exteriores opostas estão invertidas, criando oposição entre um espaço 
positivo e outro negativo, de ponta cabeça. Um caleidoscópio de diagramas que seguem uma lógica própria.

Todas as casas anteriores são diagramas que representam a transformação de uma forma geométrica pura, que parte de questões anteriores, pré-definidas. Com a casa VI tem início um processo de decomposição no lugar de transformação. A matéria diagramática é informe e o resultado do espaço oscila entre possíveis explicações que levam a outras questões sempre em estado de suspensão. Às camadas verticais em progressão linear como no Terragni da Casa Del Fascio e no Corbusier da Vila Stein é agregada a idéia de centralidade. Se, segundo a leitura do próprio Eisenman [1970] e de Rowe [1985] respectivamente, aquelas obras têm como origem o plano vertical que assume qualidades literais e fenomenais na construção do espaço, a Casa VI sobrepõe a isso um centro sem coordenadas, dissipando a origem do espaço que se dispersa em todas as direções.

\section{CASA X PONTO DE INFLEXÃO E CRÍTICA}

A estrutura sintática que permite imaginar uma série infinita de possibilidades na lógica da linguagem, passa a ser questionada a partir da Casa VI. A experimentação da sintaxe leva a reconhecer procedimentos da tradição nas Casas, como a unidade da obra e da forma através do processo de composição, que se expressa através da estrutura, da malha ortogonal 

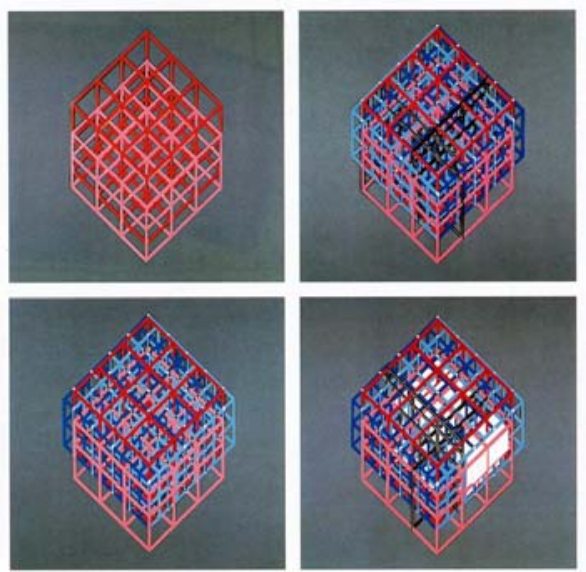

64. Casa VI: diagramas
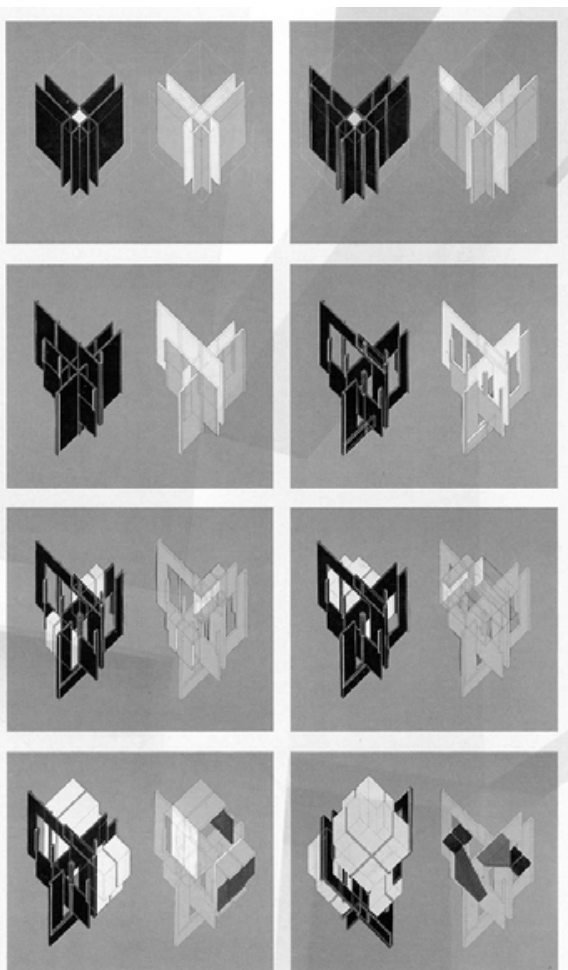

66. Casa VI: diagramas
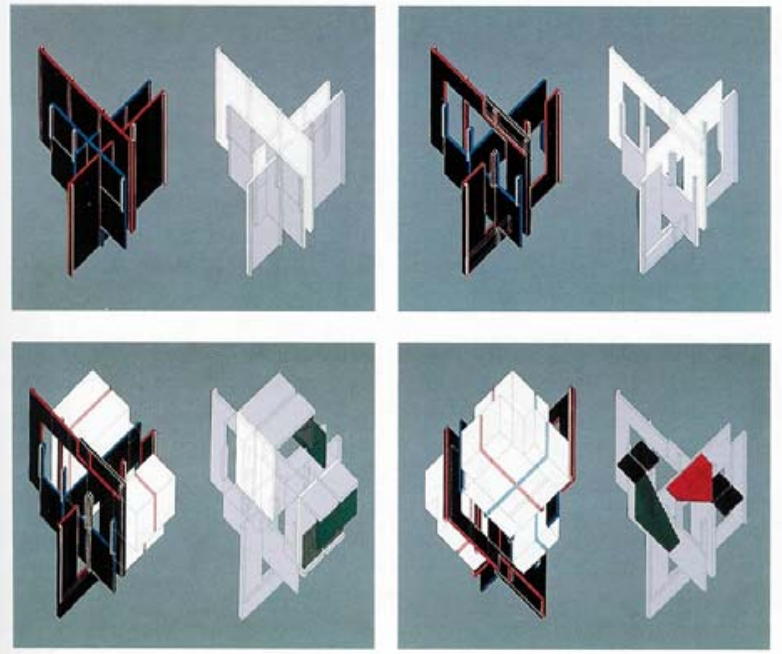

65. Casa VI: diagramas

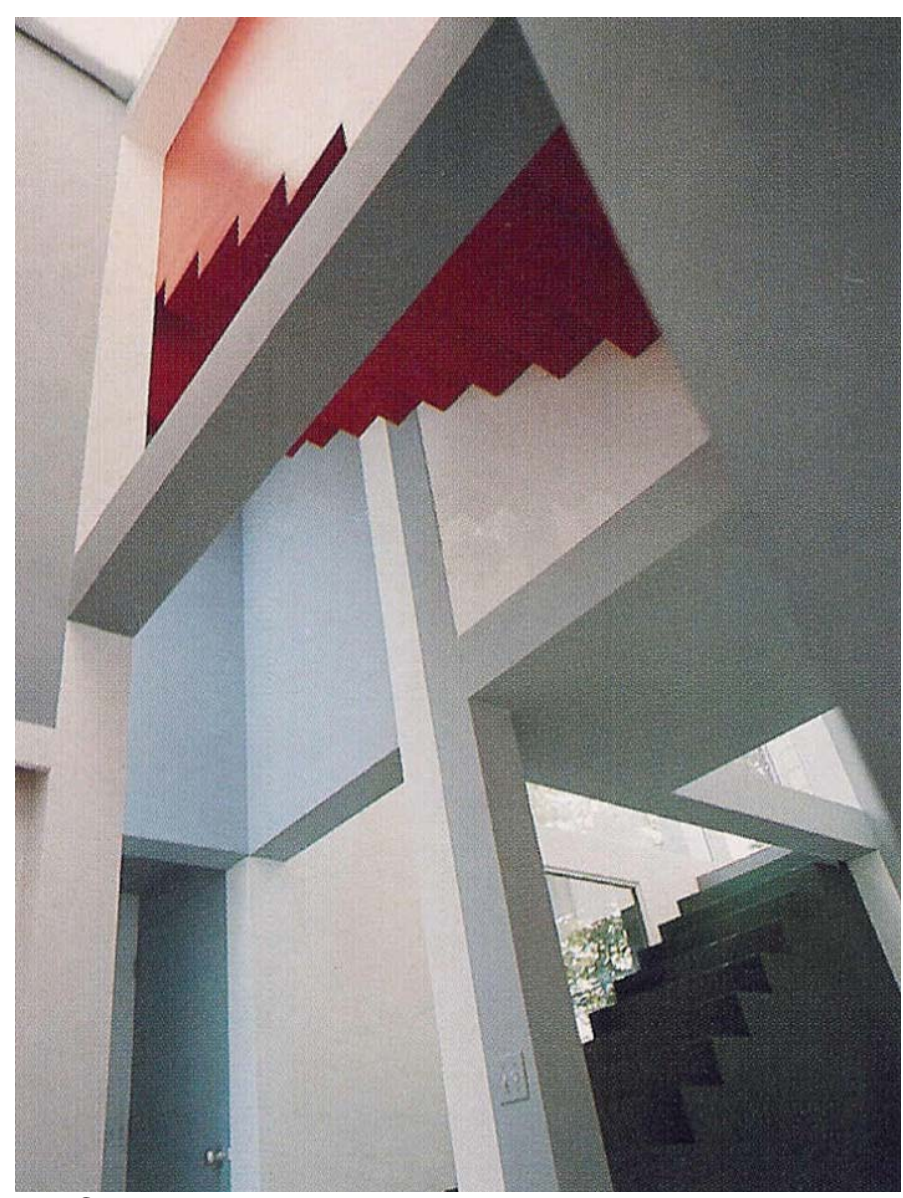

67. Casa VI: vista do interior com escadas 
cartesiana e da geometria euclidiana. Nas últimas casas emergem contradições que levam à revisão crítica da lógica operativa e ao conseqüente aumento de sua complexidade.

Segundo o próprio arquiteto, a Casa X (1975-78) é um ponto de partida, uma suspensão da certeza, que permite 0 distanciamento da racionalidade da estratégia e a distensão do formalismo. Assim, o projeto não parte da manipulação dada por um conjunto de transformações legíveis sobre elementos planos em progressão seqüencial e linear, mas surge da decomposição:

"Na decomposição, concepção e percepção não são processos cumulativos que levam ao entendimento ou revelam um princípio de ordem. Na transformação, conceitos e perceptos são ordenados seqüencialmente (geralmente de modo linear). A decomposição procede em certa desordem. (...) Como um arqueólogo, o arquiteto que decompõe reconhece e registra informações no modo em que aparecem. (...) Estas são arranjadas como dados que não apresentam relação entre si e nem relações cronológicas ou históricas. De fato, podem ser informações contraditórias ou desviantes. A única relação entre essas informações é terem sido achadas juntas no mesmo lugar. (...) Dão pistas do todo maior de que são vestígios". [EISENMAN, 1982: 38].

O processo de criação da Casa $X$ procura revelar relações espaciais inerentes a essas mesmas partes em lugar de representar definições à priori. Aqui, a interioridade da arquitetura se situa como algo instável e desconhecido [EISENMAN, 1999: 87]. A idéia de unidade que traz em si o conceito de composição, ou seja, a construção de um todo que unifique diferentes partes, cede lugar à justaposição de quatro diagramas, possibilidades de casas fragmentárias articuladas em torno de um vazio que significa a perda dessa unidade. Essa fragmentação é uma crítica ao próprio sistema em processo. 

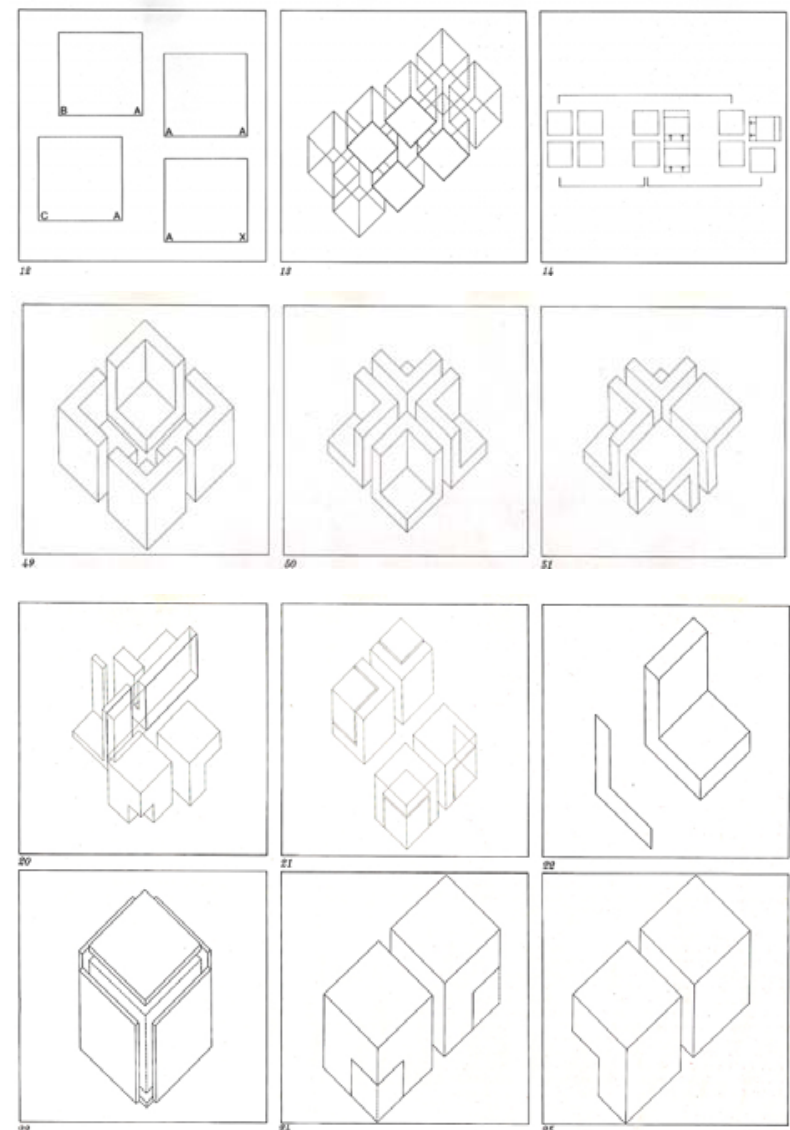

71. Casa X: sistemas, fragmentação, vazio,

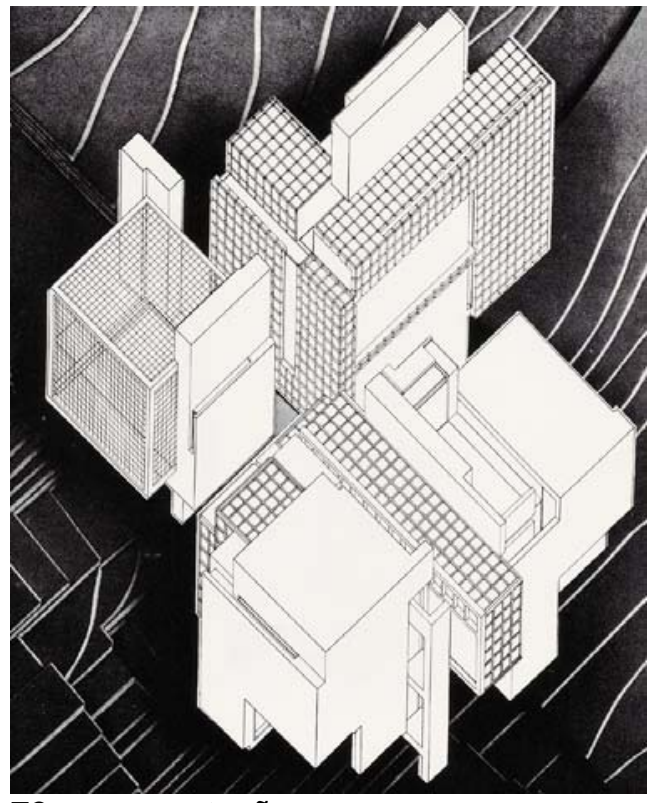

73. representação
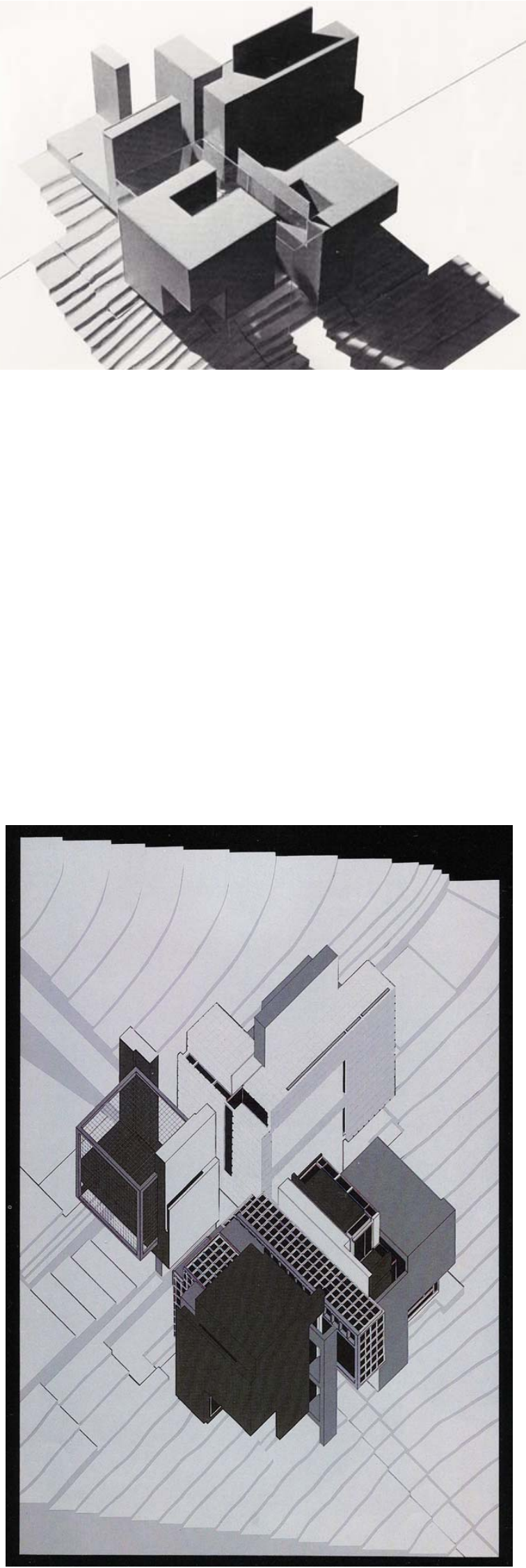

74. representação 
Na descrição que faz desse processo, Eisenman [1982: 50-78] detalha os vários diagramas utilizados e o sistema de notação formal a eles associados que permite colocar em ação um conjunto de operações. Esse sistema contém informações sobre os atributos relacionais que podem qualificar a organização do espaço. São oposições binárias como simetria/assimetria, cheio/vazio, dentro/fora, vertical/horizontal. Primeiro, há os quadrantes que apontam possibilidades de localização no espaço. A eles são associadas notações relacionais de posição e direção. Depois há os quadrados, definidos geométrica e numericamente, sugerindo possíveis relações dimensionais. A estes são relacionadas notações relacionais dinâmicas, que permitem supor rotações, deslocamentos, movimentos. Por fim há as formas "L", um fragmento, um volume incompleto que remete a um todo perdido. Todos esses diagramas são sobrepostos, suas notações entram em relação num processo de contaminação de uma parte por outra.

Essa descrição analítica da sintaxe transforma o projeto em um dispositivo heurístico, permitindo experimentar inúmeras possibilidades. Eisenman realiza esquemas, esquema A, B, G, $\mathrm{H}$ e assim por diante a partir dos quais pode testar outras operações, novas combinações que colocam em questão não só o processo em andamento (da Casa X e das Casas anteriores), mas as bases conceituais de revisão das tradições modernas.

Assim, os diagramas da Casa X não progridem, mas se desestabilizam por meio de movimentos que tem a mesma validade e o mesmo valor, o que leva cada leitura a um estado de flutuação. A divisão em quadrantes dissociados, separados por um vazio e organizados por lógicas inerentes às suas operações internas, multiplica os pontos de vista. A malha ortogonal ganha a terceira dimensão, torna-se gaiola, um 


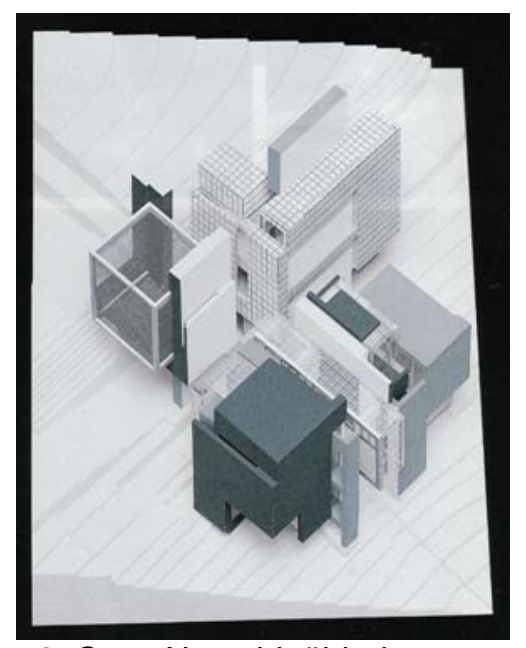

76. Casa X: ambigüidade. dispositivo formal passível de transformação, o cubo como mediação para a formulação de outra combinatória. A informação e a representação do projeto nada mais faz do que reforçar essa ambigüidade. A construção de um dos modelos tridimensionais segue as projeções paralelas das isométricas, se aproximando dos desenhos em duas dimensões, não fornecendo nenhuma informação sobre o espaço, apenas sobre o processo de decompor.

"A decomposição nada tem a ver com a arbitrariedade, pois esta parte de uma ordem conhecida. A decomposição procura por ordens desconhecidas (...) e seu resultado é uma simulação que só pode ser verificada quando alcançada. (...) O processo é de descoberta, no qual o objetivo é a revelação de consistências e regularidades através de inconsistências e incongruências (...) onde começo e fim permanecem indefinidos e o princípio dominante é incerto". [EISENMAN, 1982: 46].

\section{PASSAGENS DO PENSAMENTO}

As Casas de Eisenman, baseadas no processo que ele chamou de decomposição com a intenção de abarcar o duplo sentido implícito de decadência e ruína, significam o esgotamento do processo, como a ruína das bases conceituais do projeto moderno. Entretanto, é preciso compreender esse movimento no seu aspecto positivo, como reconhecimento de que a condição cultural contemporânea não permite sustentar a crença na racionalidade tal como antes. Por isso a Casa X é ponto de partida [EISENMAN, 1982: 34], é um diagrama que possibilita a emergência de uma outra arquitetura que tem por cúmplice a organização relacional e sistêmica da condição atual [GANDELSONAS, 1999: 22-24].

E se no processo diagramático as Casas como projeto perdem sua materialidade e se inscrevem numa condição de 
virtualidade [ARANTES, 1993: 79], como pensamento maquínico se aproximam das arquiteturas engendradas no suporte digital. Se o próprio Eisenman considera o resultado do processo como simulação, que pode ser entendida como experimentação visando dar origem ao maior número de possibilidades e variações, potencializando os objetos virtuais, esses podem ser definidos como situacionais, em total dependência das operações mentais do usuário e de suas múltiplas visões, sujeito que se confunde com a representação e o suporte [DUARTE, 1999; 160-162].

Assim, o suporte digital passa a fazer parte do processo de criação de Eisenman como conseqüência da elaboração de um pensamento afinado com sua lógica informacional. Da mesma maneira que a tecnologia numérica faz convergir modelos das ciências operando de modo sistêmico e relacional, Eisenman constrói procedimentos análogos às potencialidades de organização e simulação digital. Para ele, o computador elabora e acelera o pensamento, permitindo que as idéias ganhem outra materialidade ao se tornar informação. A matemática, a física, a biologia se tornam informações e conceitos que podem ser transformados em concepções de arquitetura [GALOFARO, 1999: 51-57]. O computador é a materialização do pensamento, no processo de gênese da arquitetura que precisa ser visualizado [GALOFARO, 1999: 66].

"Meu trabalho se baseia, em última instância, em conceitualizar outros métodos. Por isso comecei a trabalhar com computadores, pois tudo o que podemos fazer como humanos é projetar eixos e lugares. O computador conceitualiza e projeta de maneira diferente. Dependo cada vez mais de computadores porque através deles podemos produzir coisas que não podíamos à vinte anos. (. . .) Utilizo modelos de outras disciplinas porque a arquitetura não tem modelos adequados para descrever as complexidades do mundo. Com meu trabalho 
procuro definir modelos de outras disciplinas que nos permitam ter mais autonomia como arquitetos." [ZAERA-POLO, 1997: 13; 18]

O Eisenman maquínico, que faz aportar o pensamento sobre as premissas conceituais das tecnologias de informação, binária, dialógica, experimental, encontra o Eisenman digital [GALOFARO, 1999] que utiliza os computadores como ferramenta heurística, capaz de comportar relações complexas que permitem transgredir tanto a prática como as visões da arquitetura.

O Centro Aronoff de Design e Arte, da Universidade de Cincinnati, em Ohio, EUA (1988-1996) é um edifício chave para compreender a passagem do pensamento computacional e algorítmico de Eisenman para o suporte digital. Trata-se de experiência inicial, complexa, que pode ser considerada bem sucedida como experimento que aplica a noção de diagramas ao projeto em suporte digital. Experimento que entre as diferenças do pensamento conceitual e sua mediação digital, revelou contradições tanto no processo de fazer como na forma resultante. Eisenman coloca em relação e procura estabelecer diálogos entre as informações pertinentes ao projeto, como o programa, a topografia do terreno e a situação do entorno. Esses dados traduzidos em diagramas e sobre eles se aplicam duas séries de transformações, através de funções algorítmicas e superposições: deslocamento e re-orientação.

77. Centro Aronoff: diagramas e transformações.

Assim, a forma do edifício existente sugere um ziguezague e as linhas curvas indicadas pela topografia do terreno, superpostas ao programa traduzido em diagrama, geram a forma do edifício. Essas transformações estabelecem um diálogo entre essas partes heterogêneas formando um sistema dinâmico, um espaço complexo. Devido à sua forma complexa 


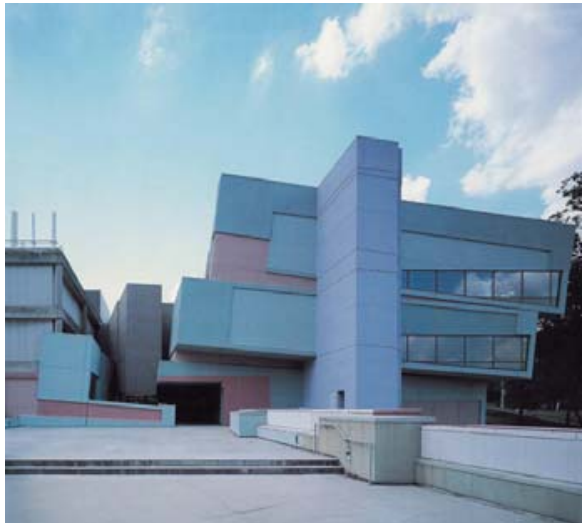

78. Vista frontal.

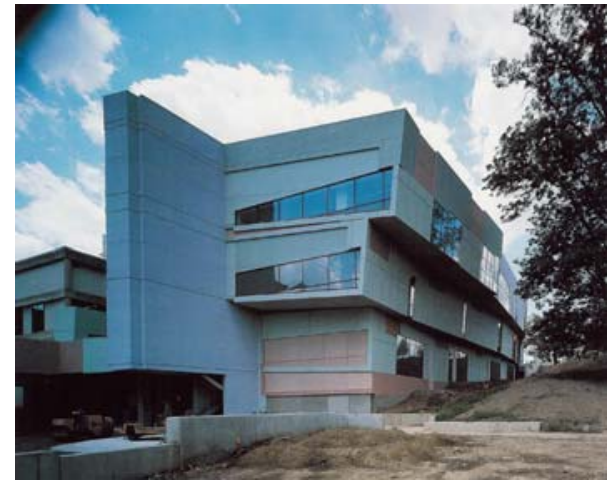

79. Vista lateral

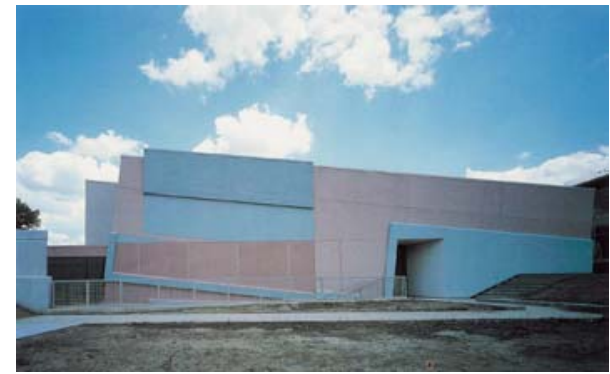

80. Vista posterior

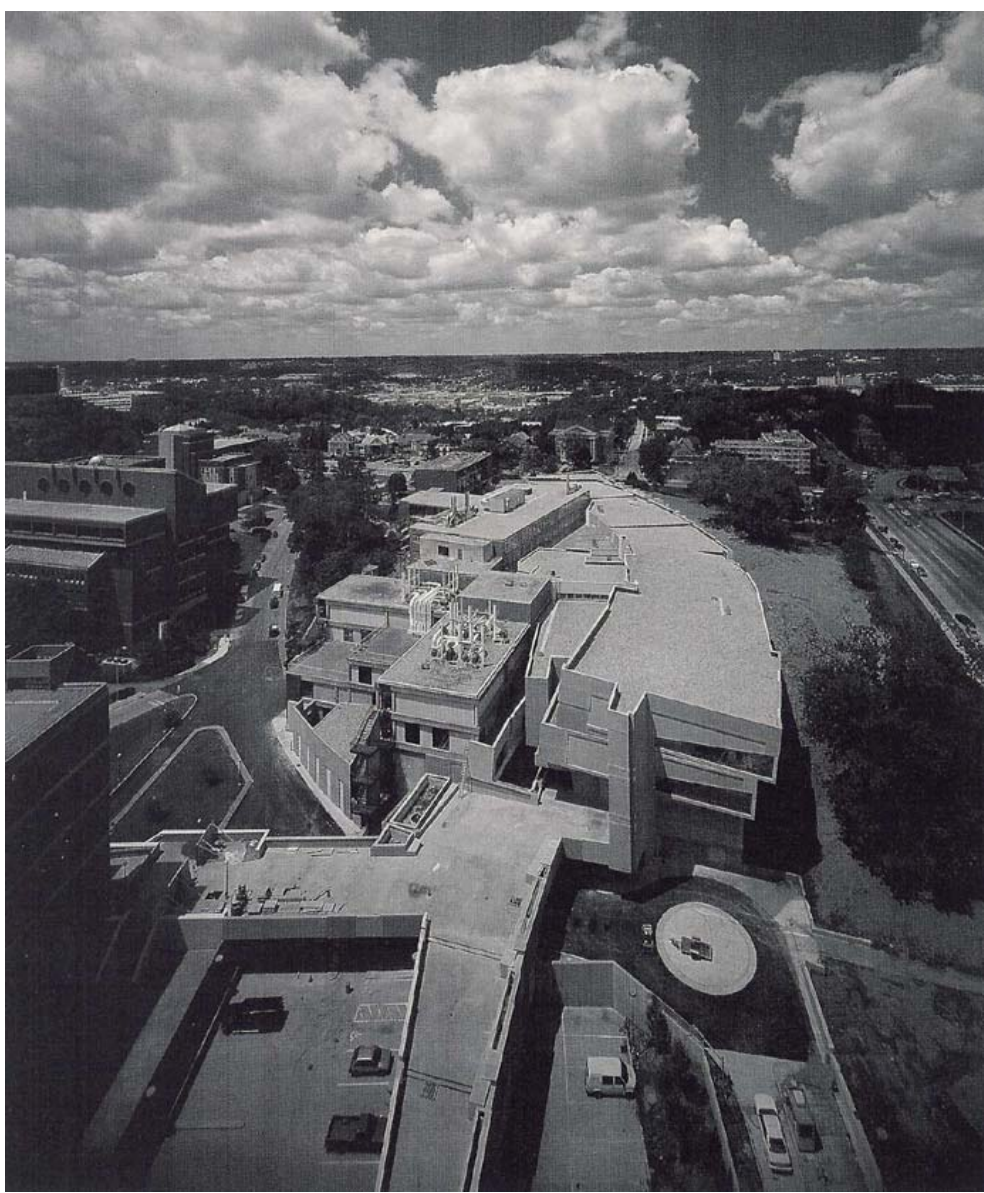

81. Vista aérea.

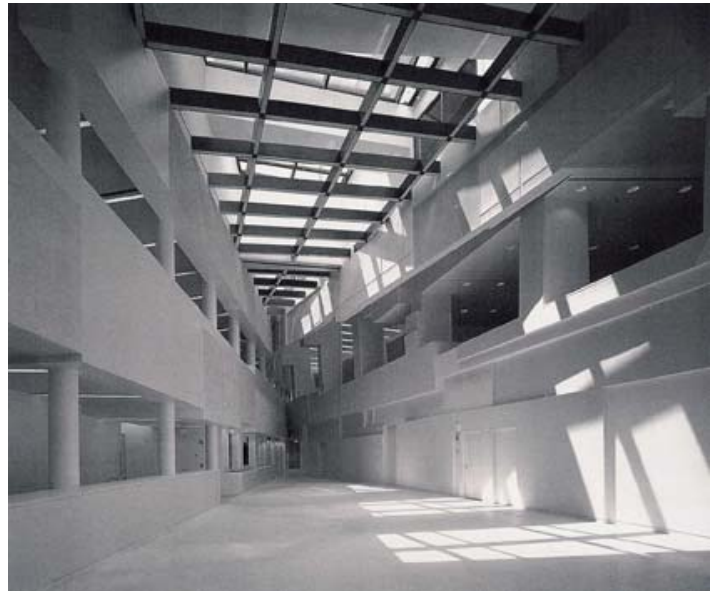

82. Interior.

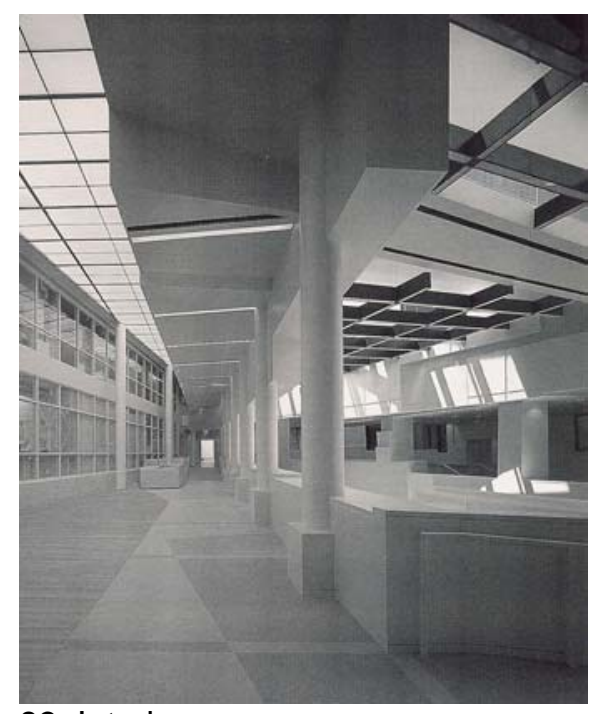

83. Interior. 


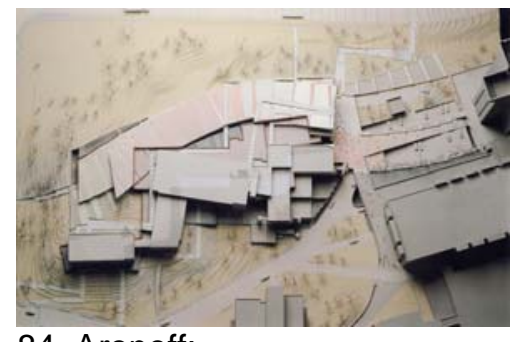

84. Aronoff:

maquete de implantação. expressa em desenhos de difícil compreensão, durante a obra, foi necessário implementar um sistema de coordenadas numéricas tridimensionais, uma retícula cartesiana e contraditória ao sistema dinâmico do edifício, para poder articular todos os projetos complementares [ZAERA-POLO, 1997: 62-63].

\section{OUTRAS DIAGRAMAÇÕES}

Com a utilização do suporte digital, a gênese do projeto de Eisenman continua tendo o caráter de um longo processo de especulação, como um procedimento de pesquisa em que se defrontam conceitos, modelos e experimentações. $\mathrm{O}$ destino do projeto se define à medida que as ações, interações e simulações apresentam possibilidades de prosseguimento. São diagramas traduzidos em maquetes e modelos digitais. Os conceitos representados em diagramas são definidos a cada projeto, segundo as características e condicionantes de cada

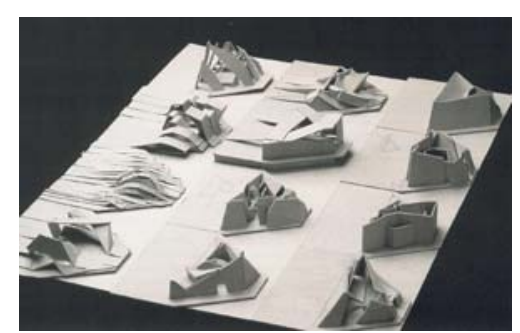

85. Catedral do ano 2000: maquetes

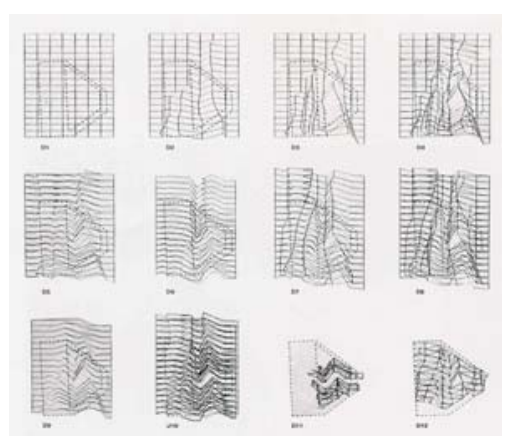

86. Evolução do diagrama

\section{programa.}

No concurso de projetos para a Catedral do ano 2000, em Roma, (a igreja da era da informação, segundo o arquiteto) Eisenman realiza uma reflexão sobre o papel da igreja na atualidade. Sua presença como meio de comunicação e vetor de atração de peregrinos, lugar de comunhão. O diagrama inicial consiste em duas barras paralelas e o vazio entre elas. Representam duas premissas: um, a relação entre proximidade e distância implícita na idéia de peregrinação e dois, as transformações na relação entre homem, Deus e natureza. Eisenman encontra no cristal líquida essa qualidade intermediária, em estado de suspensão entre o cristal estático e o fluxo líquido. 

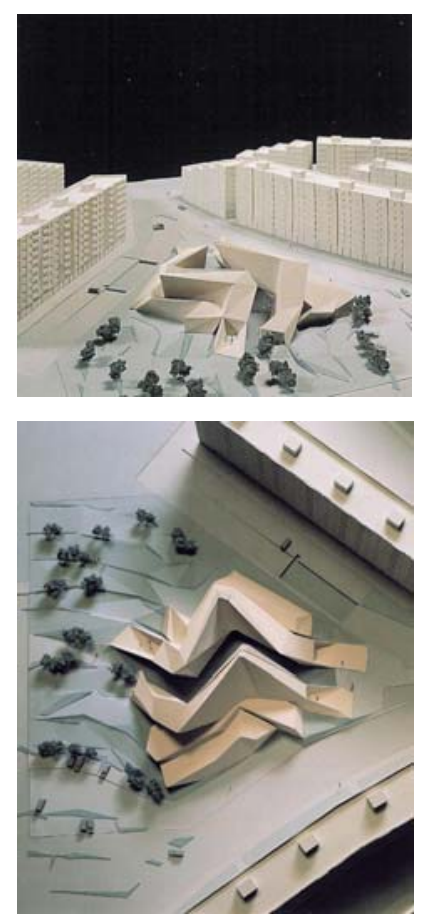

87 e 88.

maquete: implantação

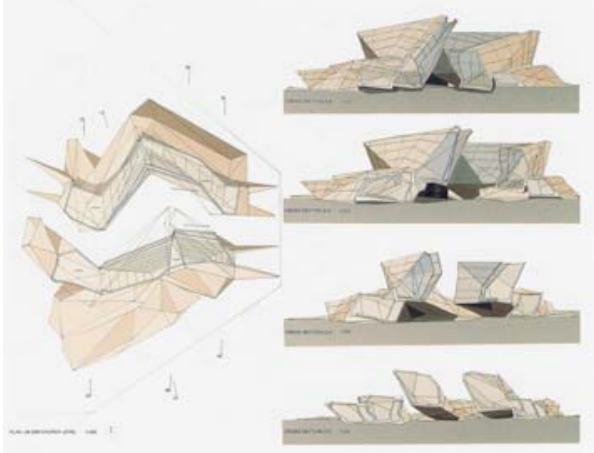

90. planta e elevações

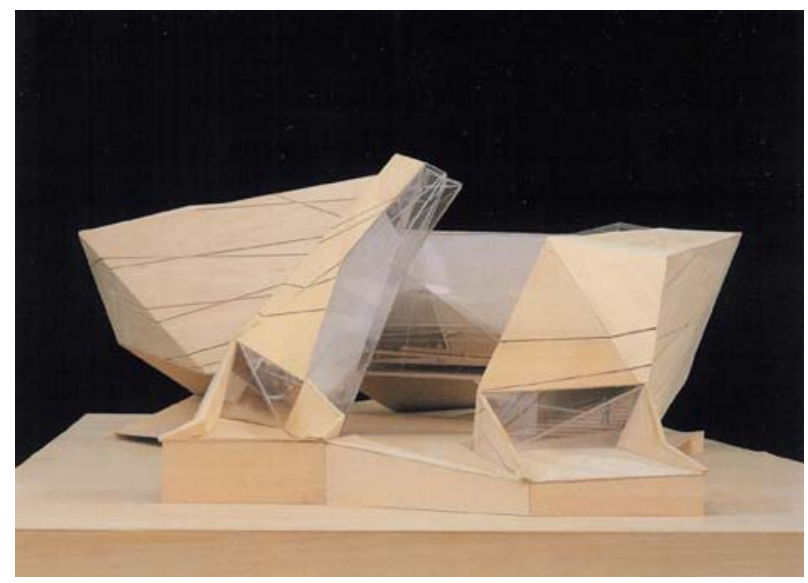

91. maquete
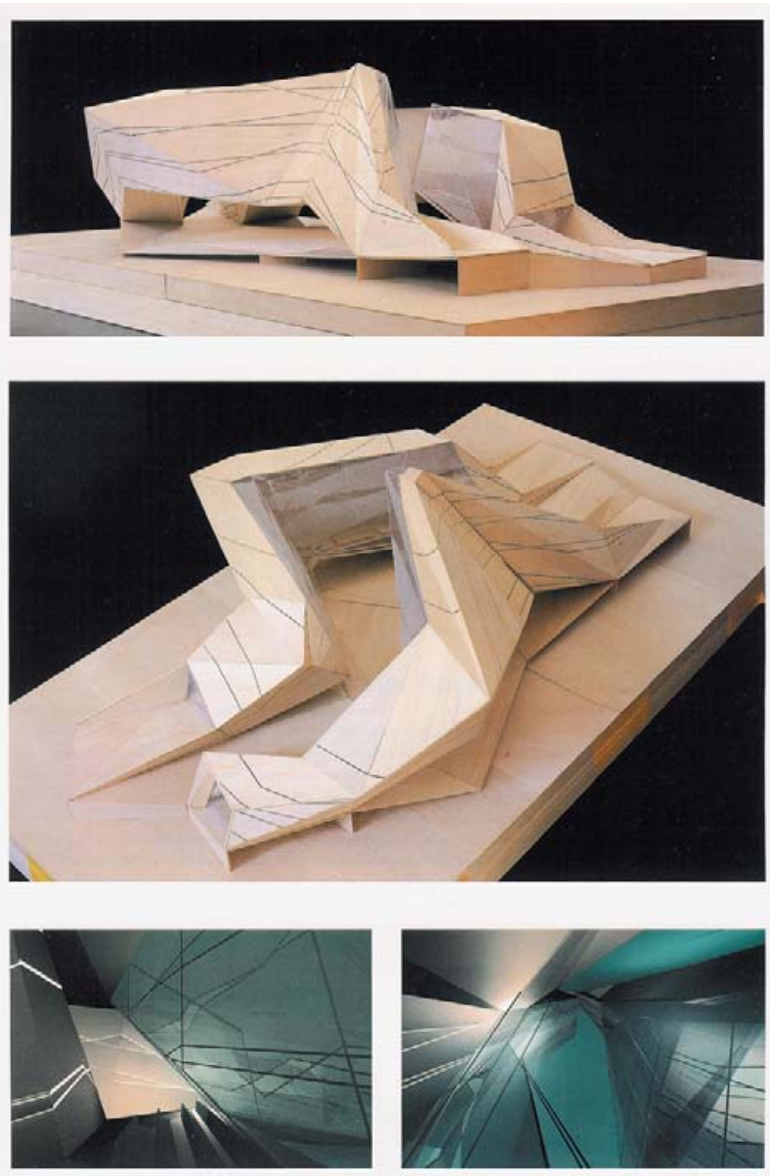

89. maquete e representações digitais do espaço interno

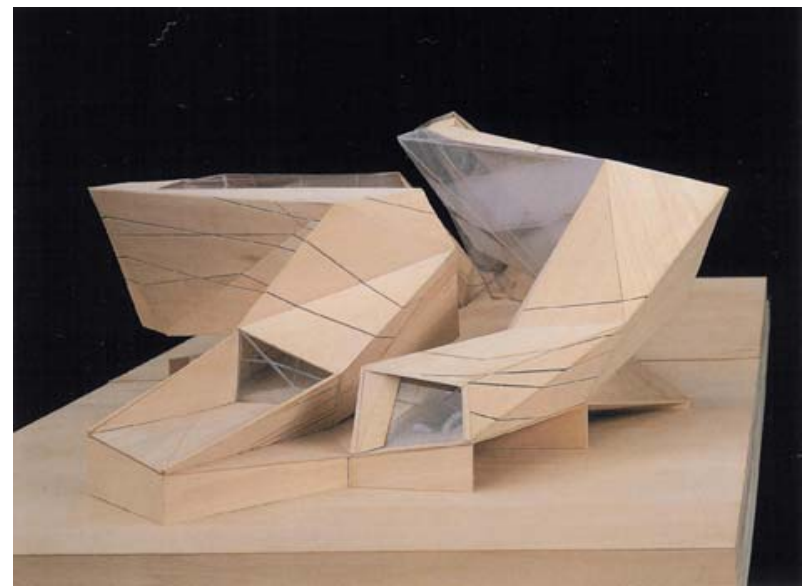

92. maquete 


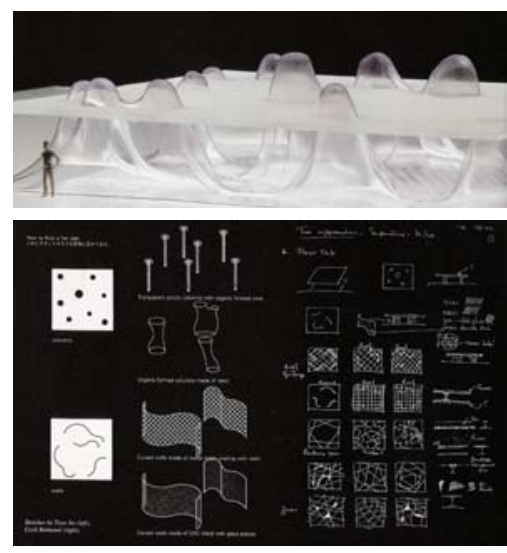

As formas da igreja surgem da superposição do diagrama inicial sobre os diagramas da ordem molecular do cristal líquido em sua transformação gradual da origem até o limite de alcançar a fase líquida. Tensão entre opacidade e transparência presente nas faces do edifício representa a comunicação e os mistérios do sagrado. Os painéis transparentes são de cristal líquido cumprindo a dupla função de abertura para receber a luz e superfície midiática para transmitir informações [GALOFARO, 1999; EISENMAN, 1997].

Outro arquiteto que utiliza o diagrama como procedimento é Toyo Ito. Um exemplo seria o projeto para a galeria Serpentine, em Londres (2002). O projeto se caracterizou como uma colaboração entre Toyo Ito e a engenheira estrutural Cecil Balamond, do escritório ARUP. Para conceber o espaço de $300 \mathrm{~m}^{2}$ anexo à galeria, abrigando um pequeno café e área de eventos, Ito fez duas questões à engenheira: como fazer flutuar um plano e como construir uma caixa sem colunas. A intenção era não subordinar a arquitetura aos seus elementos básicos como pilares e vigas, paredes e coberturas, aberturas e acessos. Ao contrário, todos os elementos deveriam se comportar como um organismo sistêmico em que as partes não se distinguem do todo como elementos isolados.

Cecil propôs um diagrama traduzido em algoritmo randômico que gerou um padrão de combinações geométricas para o plano de cobertura. Dessas combinações derivam a dimensão e a forma de cada peça de suporte. O conjunto é um todo complexo resultado de relações matemáticas traduzidas plasticamente. 


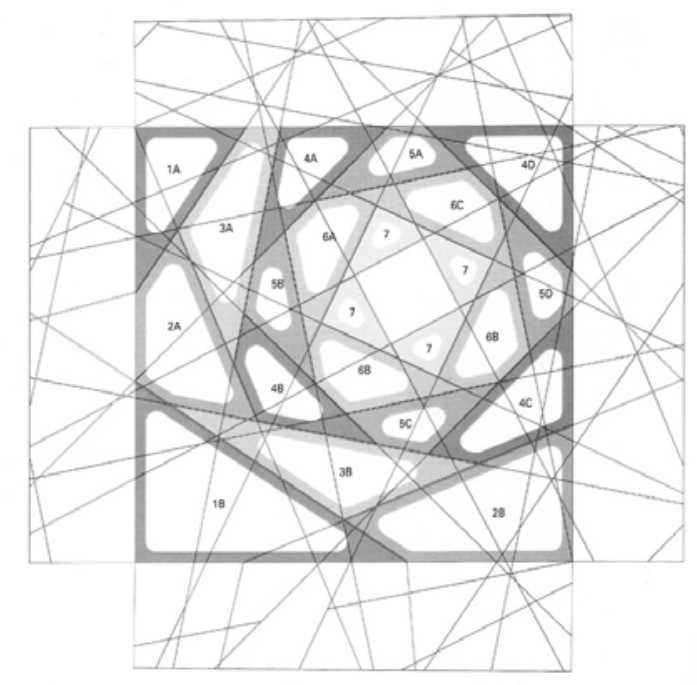

94. diagrama de forças da cobertura
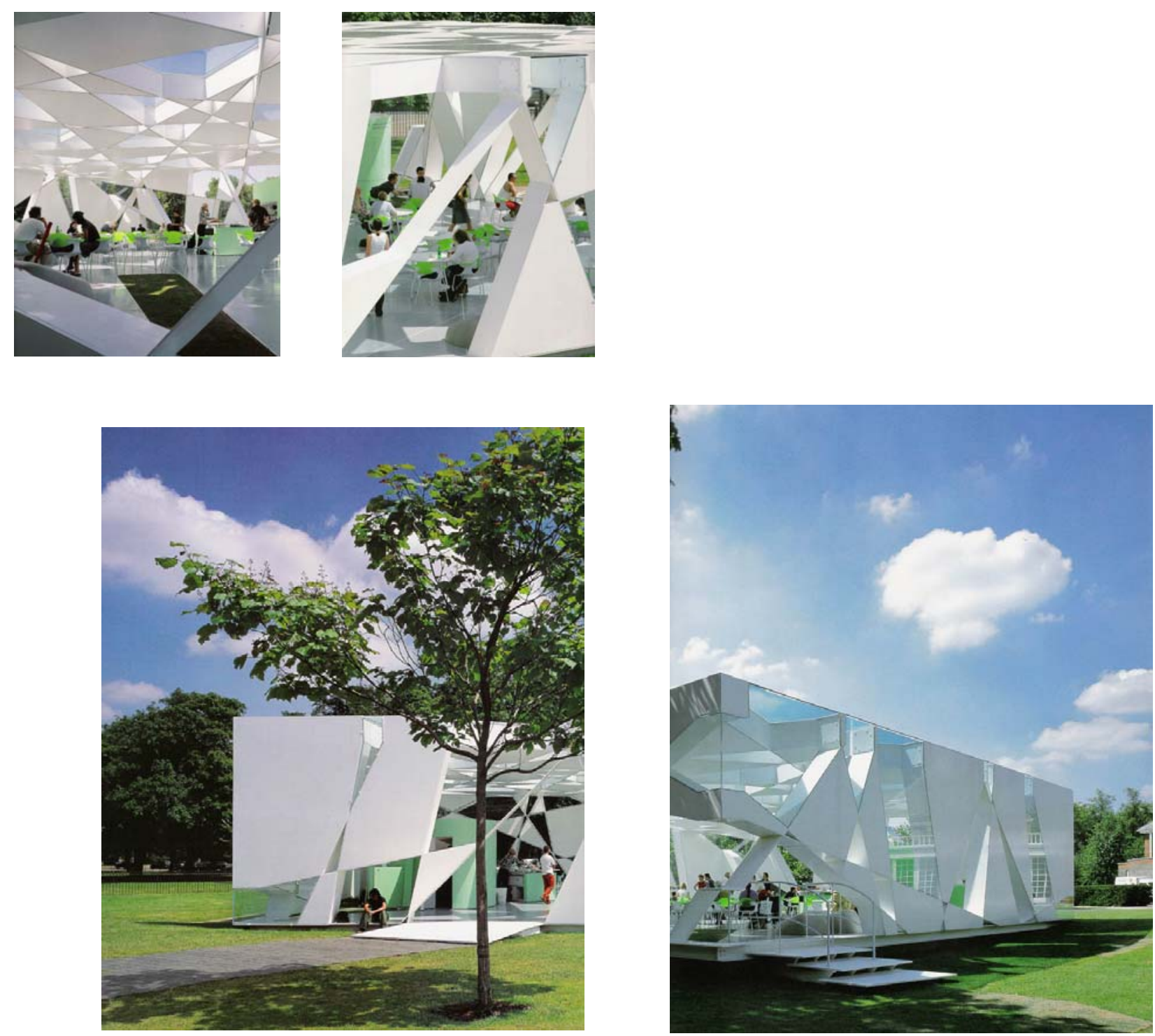
Outro projeto que exemplifica a arquitetura diagramática
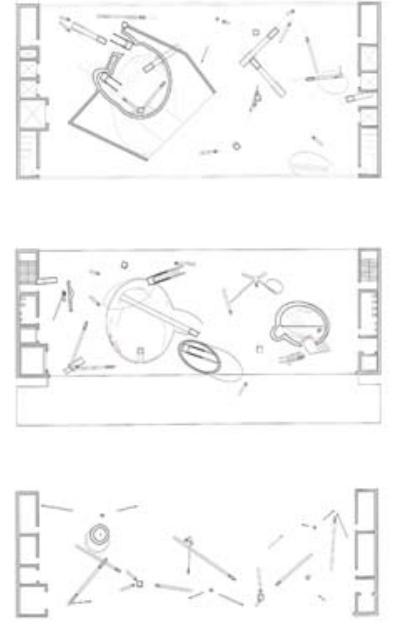

99. plantas

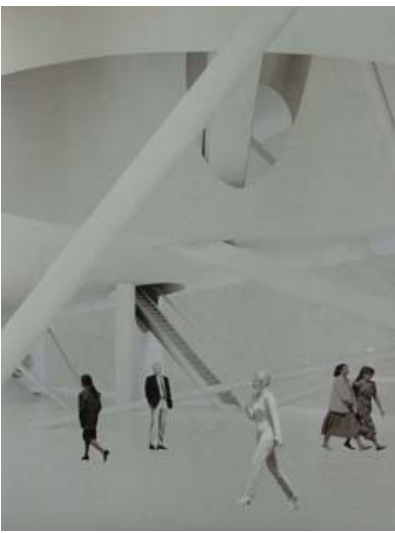

101. vista interna

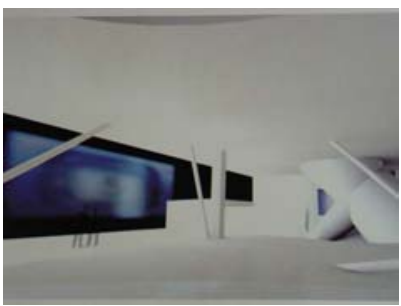

102. vista interna

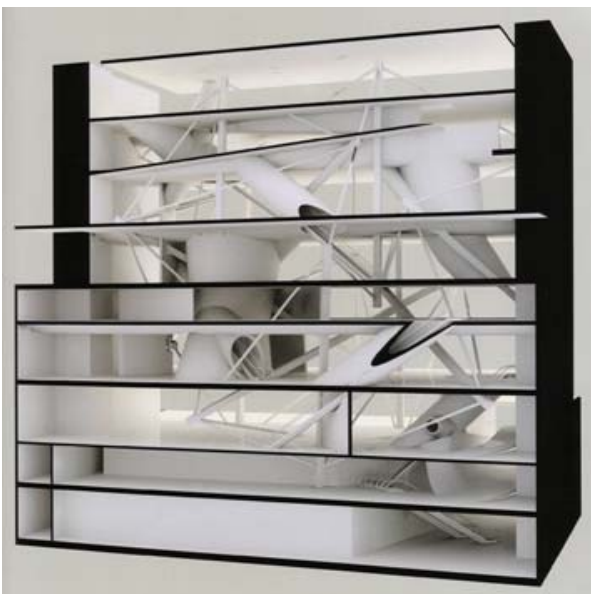

103. maquete é o Museu de arte e tecnologia, desenvolvido por Preston Scott Cohen, batizado por ele de Eyebeam Atelier (Nova Iorque, 2001). Segundo Cohen, o projeto pretende representar a simbiose entre mídia digital e espaço arquitetônico, em que os elementos se relacionam sob tensão, assim como na cama-degato o barbante só assume um desenho que permite prosseguir o jogo se tensionado. Para ele, o computador amplifica a possibilidade de emergir a complexidade, o que em arquitetura significa 'exponenciar' a proporcionlidade, um sistema de sistemas de proporção. O suporte digital intensifica a predisposição da arquitetura para o raciocínio analógico e diagramático.

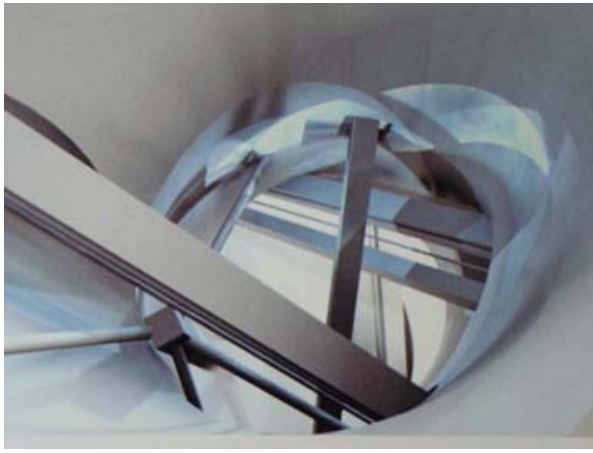

100. detalhe da estrutura
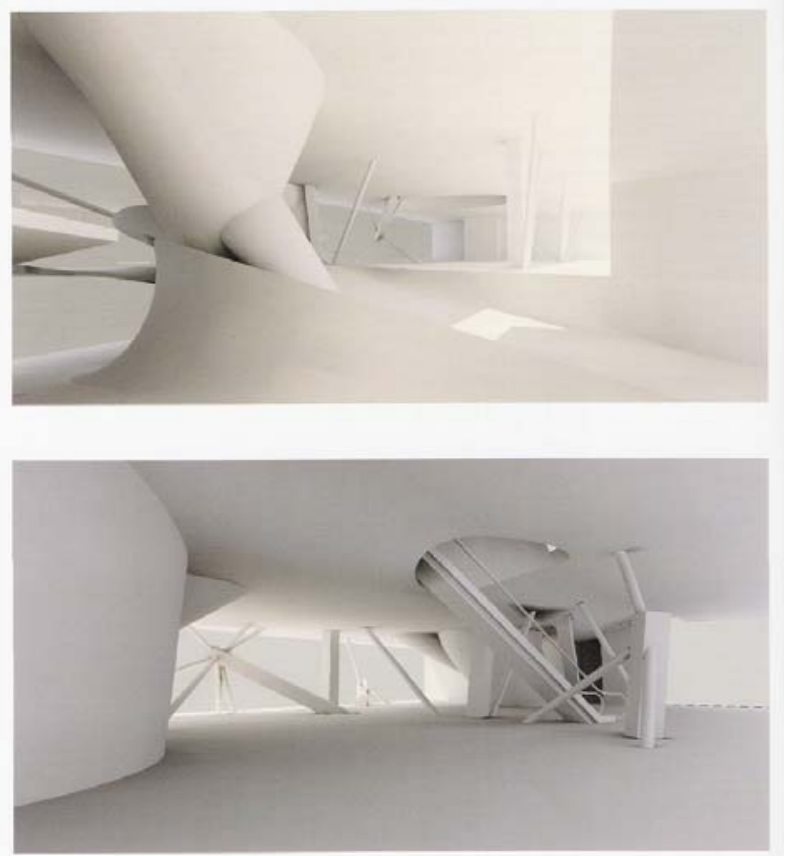

104. detalhes do interior 
Seguindo com as reflexões de Eisenman, quando a razão se desvincula da visão muda a natureza do espaço e a construção da arquitetura pode revelar um pensamento livre para formar outras possibilidades. Essa visão deslocada exige que a razão encontre suas representações se descolando da expressão do desenho e das funções programáticas. É como, segundo ele, se a arquitetura pudesse ser concebida como uma tira de Moebius, numa continuidade ininterrupta entre interior e exterior. Este seria um espaço dobrado que altera o espaço tradicional conformado pela visão e resignifica as relações constituintes da arquitetura com qualidades do ainda não visto. A dobra remete a um espaço contínuo-ilimitado, além da razão, do significado e da função [EISENMAN, 1993: 17].

A análise de Eisenman se baseia no conceito de dobra criado por Deleuze [1991] em suas reflexões sobre Leibniz e o Barroco. E a dobra barroca se revela com toda intensidade na arquitetura, pois é nela que se pode encontrar a caracterização do conceito. A dobra é uma operação infinita, de harmonia indireta entre interior e exterior, de continuidades extensivas, de informalidade da matéria, de texturas que resultam do fazer [DELEUZE, 1991: 66-72]. E se o Barroco significa absurdo ou grotesco e se reconhece como o plural, visões no lugar de visão [GOMBRICH, 1979: 301-303], a dobra é o que pode conferir seu reconhecimento. Representação de um mundo constituído por séries divergentes, a dobra é infinitiva e relacional, dobrar, desdobrar, redobrar [DELEUZE, 1991: 228]. Dobrar, desdobrar, não significa apenas tender-distender, contrair-dilatar, mas envolver-desenvolver, involuir-evoluir [DELEUZE, 1991: 22].

Segundo Deleuze, o elemento genético ideal da dobra ou da curvatura variável é a inflexão. A inflexão é puro 
acontecimento da linha ou do ponto. Lugar da cosmogênese, ponto não-dimensional, ponto entre as dimensões. A inflexão sofre transformações, projeções, variações. Mais que linha, menos que superfície, a inflexão é turbulência, sua variação é flutuação. Sempre há uma inflexão que faz da variação uma dobra e que leva a dobra ou a variação ao infinito. [DELEUZE, 1991: 32-37].

A dobra remete à Teoria das catástrofes, de René Thom que, de acordo com o neobarroco de Calabrese [1987: 126127], também pode ser chamada de dinâmica das morfologias. Uma forma pode sofrer perturbações e se modificar, atravessando um limiar de catástrofe que altera sua estrutura, sua organização. É como um processo de passagem de um estado a outro, que encontra um limite, uma situação de estresse repentino, na dobra que perturba o plano. Segundo Jencks [1997: 53-59], dos sete tipos de catástrofe na teoria de Thom, dois são representados por dobras: a cúspide é uma dobra no espaço tridimensional. A dobra em arquitetura pode comportar qualidades opostas: uma mudança repentina de direção ou dimensão, ou ainda agregar conflitos numa pluralidade.

E a dobra é tanto pensamento como coisa formada, tanto material como procedimento, é arquitetura como projeto e como forma construída, reflexo do mundo como multiplicidade. É possível considerá-la, assim como o Barroco, como qualidade sincrônica da transgressão subjacente à cultura. Pensar é dobrar, é duplicar o de-fora em um de-dentro que lhe é coextensivo, numa espécie de topologia feita de séries que avizinham singularidades [DELEUZE, 1998: 157-159]. A dobra que se redobra em forma tem como desdobramento a matéria que, por sua vez, leva ao problema do fazer, do construir. A 
relação estática forma-matéria tende a ser sobreposta pela relação dinâmica material-forças.

Dinâmica de forças como no talhe da pedra capaz de captar e compor as forças de resistência necessárias para construir a abóboda, que já não é simplesmente forma, mas uma linha de variação contínua das pedras [DELEUZE e GUATTARI, 1997b: 29]. Forma e matéria não estão conectadas por relações de moldagem, que assim permite apreender uma modulação contínua perpetuamente variável, própria da matéria em movimento, em fluxo, em variação, como portadora de singularidades e traços de expressão. Daí decorrem conseqüências evidentes: essa matéria fluxo só pode ser seguida [DELEUZE e GUATTARI, 1997b: 91].

Segundo Simondon [1964: 27-59], a transformação da matéria da existência física para a existência energética implica em reconsiderar sua relação com a forma. Há duas possibilidades de mediação tecnológica: moldar e modular. A operação de moldar pressupõe um limite que impõe uma forma, colocando fim ao processo de deformação da matéria. A ação de modular pressupõe moldar continuamente, não há limite que resulte em forma definida ou definitiva. A matéria que se presta à modulação é energia em fluxo, informação.

Assim, as primeiras matérias elaboradas em forma pelo homem são aquelas que já possuem em sua essência uma estrutura legível, a pedra e seus agregados, a madeira e suas fibras. O metal como material e a metalurgia como intermediação tecnológica correspondente, teriam inaugurado a transformação por operações sucessivas que resultam em formas não previstas na própria estrutura da matéria [SIMONDON, 1964: 58-59]. Moldar e modular são dois 
extremos da ação de modelar, formar a matéria. Em comum, requerem que o homem se coloque no processo através da antecipação das etapas de intermediação, que crie os mediadores.

"Moldar é modular de maneira definitiva; modular é moldar de maneira contínua e perpetuamente variável." [SIMONDON, 1964: 42]

Argan já havia ressaltado que toda mediação sobre a matéria seria revestida de espacialidade. Entretanto, apesar de tratar da matéria física relacionada aos procedimentos do formar, Argan aponta para algo que está além dessa materialidade:

"Toda a intervenção operativa na matéria, mesmo a mais simples, a constitui como valor de espaço: ela é polida, lustrada, burilada, esculpida, modelada, para modular a sua reação à luz, portanto mais uma vez ao espaço, para definir as distâncias em que a peça de matéria lavrada terá possibilidade de relação, será algo além da própria realidade física, se dará como fato especial". [ARGAN, 2001: 18]

Deleuze, seguindo Simondon, parece prolongar o dizer de Argan usando com referência a metalurgia para ir ainda mais além. Para Deleuze, a metalurgia é a consciência ou o pensamento da matéria-fluxo, que permite um desenvolvimento contínuo da forma e uma variação contínua da matéria [DELEUZE e GUATTARI, 1997b: 94]. A matéria informe leva ao informal, que por sua vez leva à matéria fluxo, energia. Mesmo afirmando que o número sempre serviu para dominar a matéria e controlar suas variações e seus movimentos [DELEUZE e GUATTARI, 1997b: 64], agora como fluxo de energia informal, a matéria é imaterial, matéria molecular que deve capturar forças do cosmo. A matéria se mistura ao número, o numérico digital imaterial e sendo assim só pode ser modulada. 
A idéia de modulação já havia sido representada por Cézanne que, em suas leituras da natureza por manchas coloridas, dizia que tudo se modula, portanto espaço, cor e plano do quadro se fazem sobre outra concepção de matéria. [COUCHOT, 2003: 46-48]. Se o visual deve capturar forças não visíveis, tornar visível, como pintou Cézanne e declarou Klee [DELEUZE e GUATTARI, 1997a: 158-165], como consolidar um material para que possa captar forças não pensáveis? Frente a um material dessa natureza, não se trata mais de elevação ao infinito, nem de encontrar a finitude, mas de um processo finitoilimitado: um número finito de componentes produz uma diversidade quase ilimitada de combinações. Nem dobra, nem desdobramento, mas sobredobra ou superdobra, característica das cadeias do código genético ou nas potencialidades do silício nos computadores, no retorno da linguagem sobre si mesma [DELEUZE, 1998: 167-179].

"A matéria é uma substância não-formada, física ou semioticamente". [DELEUZE e GUATTARI, 1995: 99].

\section{O PAPEL FUNDAMENTAL DO MATERIAL}

Grande parte das vezes em que se recorreu à aplicação ou à transposição do conceito de dobra na arquitetura, a ênfase na leitura ou na concepção da obra foi dada à forma. Jencks [1997: 52-59] relacionou a arquitetura de Peter Eisenman e Zaha Hadid aos espaços dobrados, chegando a dizer que a arquitetura de modo geral, por meio de tantas aproximações científicas, está se tornando topomórfica (land-form) [JENCKS, 1997: 171-185]. O número da revista inglesa Architectural Design: Folding in architetcture [1993] dedicado à dobra também centrou sua edição no problema da forma, na arquitetura como resultado formal. 
Entretanto, o conceito de dobra não parece estar reduzido a um mero desempenho formal no espaço. Se como disse Eisenman, a visão se libera da razão e se desdobra em visões, é preciso encontrar o que há de essencial nos espaços dobrados da arquitetura. A resposta pode estar no espírito experimental de Frank Gehry que revela sua busca contínua e sempre variável por materiais e a conseqüente descoberta dos procedimentos a serem adotados para transformá-los em materiais construtivos.

Gehry nasceu no Canadá e estudou arquitetura na Califórnia dos anos 50, quando o grande arquiteto da costa oeste norte americana era Richard Neutra. Sua carreira teve início em 1962, quando montou seu próprio escritório em Los Angeles. Por muito tempo enfrentou resistência ao seu trabalho, circunscrito àquela região do país e foi considerado com freqüência como arquiteto que quebrava regras em demasia. Longe da academia, mas próximo das artes e de artistas do Pop art, seus contemporâneos, como Claes Oldenburg, Frank Stella, Richard Serra e Robert Raushenberg, Gehry é o que se costuma chamar de arquiteto de obra ou de canteiro. Íntimo do fazer da obra manifestou preferir a obra enquanto em andamento no lugar de acabada, pois, segundo ele, a obra em construção, work in progress, reflete a incompletude da existência humana [HINES, 1986: 11-21].

A vivência californiana, a experiência extensiva da cidade de Los Angeles com seus arrabaldes cenográficos em quase decomposição, e ao mesmo tempo intensiva das imagens em profusão da indústria do cinema, somadas a intimidade com artistas plásticos, escultores e pintores, podem ter influenciado a maneira de pensar e fazer arquitetura de Gehry. Segundo ele mesmo, a cidade representa a lógica norte-americana do pós- 


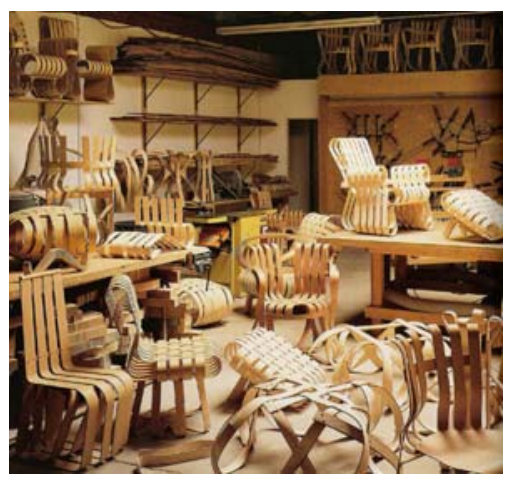

105. Gehry: oficina de criação de mobiliário

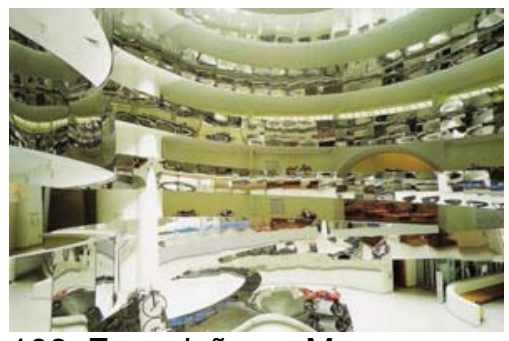

106. Exposição no Museu Guggenheim de Nova Iorque guerra de desenvolvimento acelerado que busca o resultado imediato que faz proliferar a arquitetura efêmera do fast food como em nenhum outro lugar [ZAERA-POLO, 1995a: 6]. Uma das características que parecem derivar daí talvez seja sua dedicação ao desenho de objetos, luminárias e mobiliário e projetos de montagens de exposições em museus e cenários para shows e espetáculos [FRIEDMAN, 1986: 87-108]. Segundo ele mesmo:

“A razão pela qual faço móveis, luminárias e exposições é por serem como fast food. A gratificação é rápida . . . se agita, está construído, está feito. É muito estimulante. É teatral." [FRIEDMAN, 1986: 87]

Essa arquitetura efêmera permite experimentar com materiais e descobrir suas potencialidades, suas aplicações e 0 modo mais adequado para trabalhá-los construtivamente. Acima disso, possibilita experimentar materiais não usuais, novos para as aplicações pretendidas. Para tanto, é preciso um olhar desautomatizado, capaz de enxergar aquilo que está implícito como possível, procedimento freqüente no campo das artes plásticas:

"Minha abordagem é diferente. Eu procuro obras de artistas e as uso como inspiração. Tento me livrar do peso das amarras da cultura para achar novos caminhos para trabalhar. Eu quero estar aberto. Não há regras, nem certo nem errado. Fico confuso entre o que é feio e o que é bonito." [BLETTER, 1986: 25]

$\mathrm{O}$ arquiteto passa a ver com outros olhos o cotidiano, as coisas comuns, seu olhar se volta para materiais baratos, banais, que ele pretende transformar, atribuir valor, qualificar. Ele os escolhe por suas qualidades, por sua constituição e possibilidades formais e opera experimentos singulares, como é o caso de seus móveis de papelão [FRIEDMAN, 1999: 11]. 
Já se passavam quinze anos de prática profissional quando Gehry decidiu ampliar sua pequena casa em Santa Monica na Califórnia. Essa obra transformou-se em um grande laboratório experimental, onde vários materiais foram usados de maneira inovadora resultando numa forma arquitetônica também nova. Munido por um orçamento restrito, Gehry teve que procurar materiais baratos, o que já era uma prática adotada em instalações e cenários. O projeto se tornou um marco em sua obra e fez com que a crítica o incluísse no rol dos arquitetos descontrutivistas. Segundo ele mesmo um equívoco que, de algum modo, atraiu a atenção como novidade, o que também o intriga, pois é essa obra que se considera como o início de sua carreira.

Gehry procurava uma alternativa para reconciliar os modos de produção da arquitetura com sua formação tradicional. Essa formação baseada nos ensinamentos modernos, no estudo da obra dos mestres do movimento moderno, pressupunha o desenvolvimento de detalhes que se tornavam impraticáveis no canteiro de obras, tanto devido aos materiais agora empregados quanto à própria formação dos técnicos. Até então, a obra de Gehry utiliza essa tradição construtiva para produzir uma arquitetura da imagem, quase pop. Segundo ele, foi nessa fase de procura que encontrou uma possibilidade na obra plástica de Jasper Johns e Robert Rauschenberg. O uso de sucatas, refugo de materiais, materiais recicláveis e descartáveis na obra dos dois artistas a partir dos anos 50 provocou no arquiteto o desejo de fazer o mesmo em arquitetura [ZAERA-POLO, 1995a: 15; GEHRY, 1999: 54].

"Tive uma formação arquitetônica bastante convencional e trabalhei com vários arquitetos que me ensinaram a utilizar mármore, madeira, metal, gesso e pedra 
resolvendo todo o tipo de detalhes elegantes. Estudei os detalhes de Frank Lloyd Wright, dos irmãos Green, de Mies Van der Rohe e de Le Corbusier. Quando comecei meu próprio escritório em 1962, era muito difícil fazer essas coisas com os orçamentos que dispunha. Tentei em alguns edifícios porque me fascinava a possibilidade de criar uma hierarquia perfeita e estruturada desde o conceito geral aos detalhes. Tentei mas a mão de obra não estava disponível, já não existia e os detalhes se tornaram inúteis e frustrantes. As pessoas habilitadas para essas tarefas tinham abandonado toda a responsabilidade social sobre seus produtos. Procurava uma outra forma de lidar com o problema quando cruzei com a obra de Rauschenberg e Jasper Johns. Eles estavam usando sucata para fazer arte e isso me inspirou a experimentar a mesma idéia em arquitetura. Pensei que tomar o caráter visual do mal acabado ou do material tosco em toda a sua peculiaridade, como se fossem cores numa paleta, talvez pudesse se converter em qualidade." [ZAERA-POLO, 1995a :15]

A atitude de Gehry parece ser bastante significativa frente ao problema colocado pelo desenvolvimento tecnológico e industrial em relação às artes, a arquitetura e em última instância a cidade, lugar de toda a experiência. É Argan que aponta para a obra de Rauschenberg como detentora da chave para desvendar o código da criação sob a lógica do consumo. Segundo Argan, a revolução industrial foi a antítese da proposta ideológica e sociológica do Barroco, que fez renascer o artesanato, o fazer como transcendência. As promessas (não cumpridas) da tecnologia industrial fizeram com que a ciência tomasse o lugar da arte. A imagem toma o lugar da reflexão. Não há ideação possível, mas consumo. E o Pop seria a arte das coisas e das imagens sem valor e identidade, descartadas, 
em aparente desordem. Não há diferença entre coisa e imagem [ARGAN, 2001: 37-43].

Contudo, se Gehry toma Johns e Rauschenberg como referências para idear uma arquitetura adequada à lógica do consumo, ele o faz para ir além da simples produção de imagens descartáveis. Ele o faz para interferir na produção procurando resgatar o papel do fazer como experimentação na arquitetura. Assim, o olhar diferenciado que enxerga possibilidades de aplicação construtiva para o compensado, a telha metálica ondulada, o papelão e a tela de arame de alambrado vislumbra potencialidades para interferir na produção industrial desses materiais.

Um bom exemplo de material que é lançado para outro patamar de valor e que provoca em Gehry esse impulso para interferir na produção é a tela de alambrado. Apesar de considerada feia, esse tipo de tela tem um uso massivo, em várias aplicações, como fechar quadras esportivas públicas ou privadas. O olhar automatizado dos usuários não consegue ver a tela, ela é consumida como qualquer outro objeto ou imagem cotidiana. Essa contradição, fascinante segundo ele, o levou à indústria com a proposta de fazer variações, novos desenhos, na produção em série. A idéia não foi absorvida, mas ele optou por adotar o material em algumas obras [ZAERA-POLO, 1995a: $17]$.

"Me pareceu que deveria tornar esse material aceitável, achar as qualidades do material que o tornasse atrativo. Então fiz a Garagem de Santa Monica e a envolvi com a tela de alambrado e fui criticado, porque era aceitável usá-la quando parecia inevitável, mas de forma intencional, não, era uma provocação". [ZAERA-POLO,

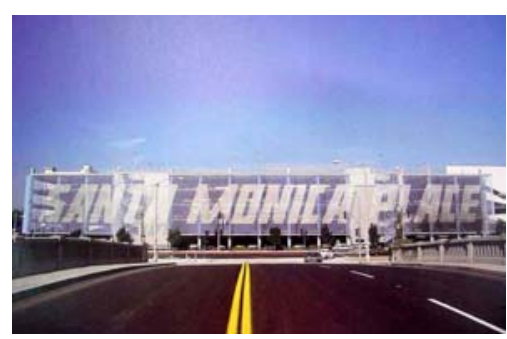

107. Garagem de Santa Mônica 1995a: 17] 


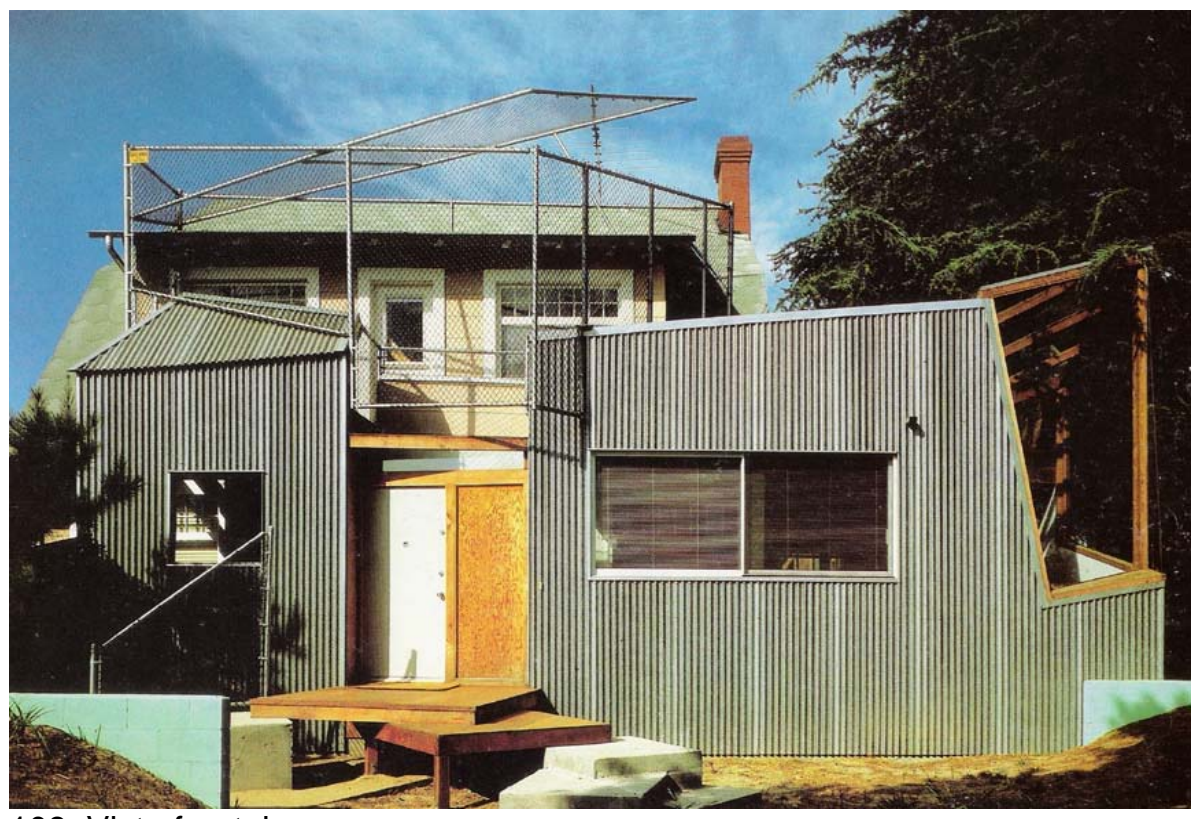

108. Vista frontal

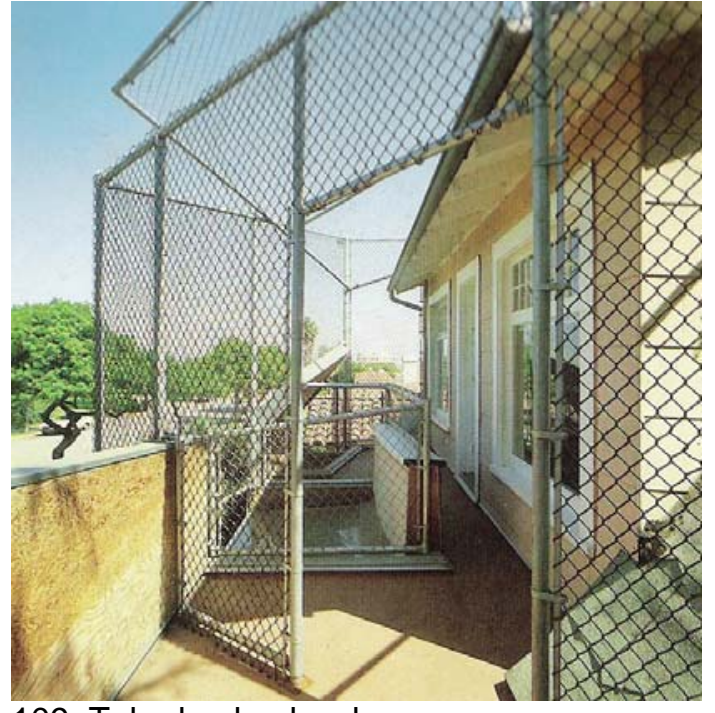

109. Tela de alambrado

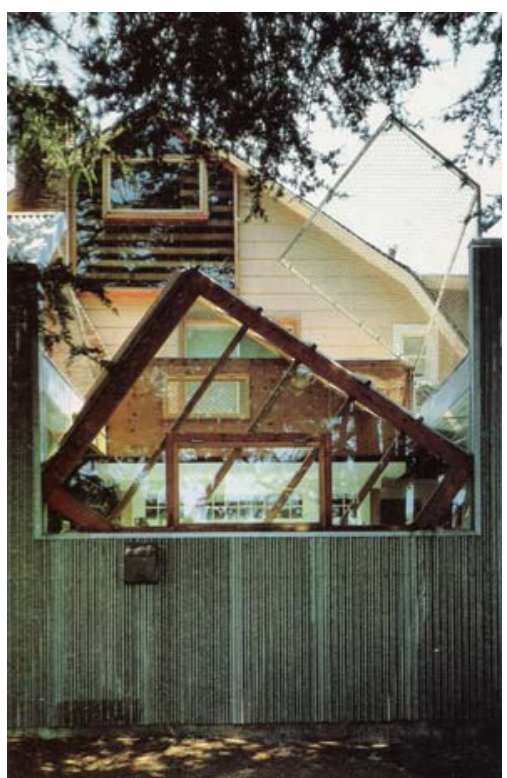

110. Muro e janela da cozinha

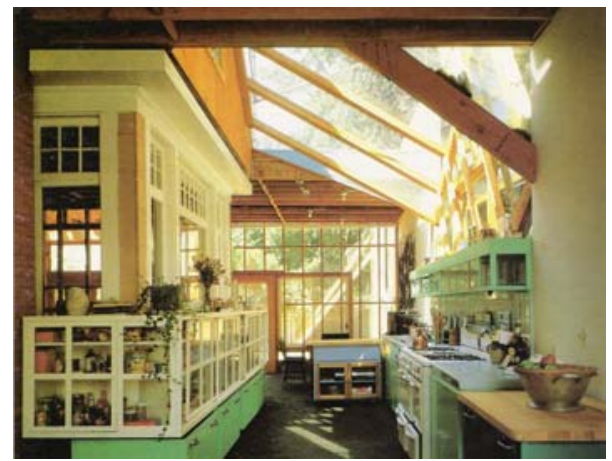

111. Interior

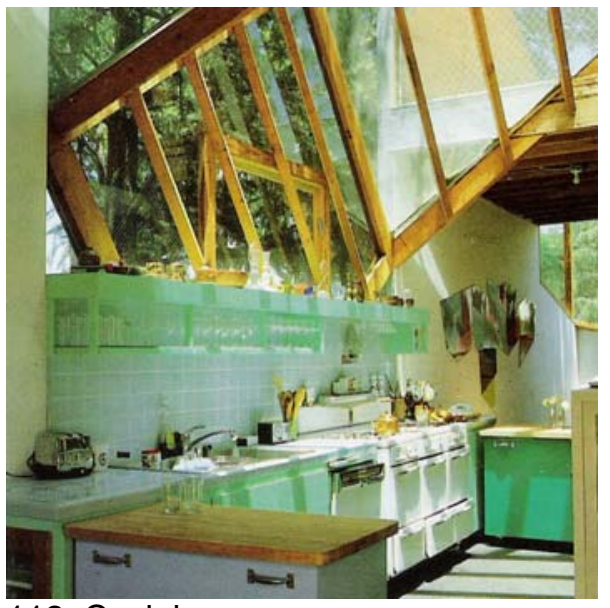

112. Cozinha 
Os materiais utilizados por Gehry em sua casa dão à obra um caráter inacabado, algo ainda em processo, impressão semelhante à que se tem frente a obra de Johns e Rauschenberg. Alberto Tassinari [2001], em belo ensaio, cunhou o termo espaço em obra para definir o espaço moderno representado pelas artes plásticas norte-americanas desde meados dos anos 50. O que define em essência esse espaço é o modo singular do fazer e se relacionar com as coisas comuns, em que o fazer se revela, se expõe como ainda em processo.

Assim, é possível dizer que a casa de Gehry é uma casa barroca, porque faz uma transição entre a arquitetura Pop como definida por Venturi [1978] e a arquitetura digital. A casa é um ponto de inflexão na obra do arquiteto tanto quanto uma inflexão no curso da arquitetura. Assim como a dobra barroca é a operação infinita que afeta as matérias e determina as formas, apontando para uma continuidade [DELEUZE, 1991: 66], a casa é um processo aberto, um experimento singular com materiais em busca de suas possibilidades formais. E se a maneira como matéria se dobra e determina a sua textura, menos pelas partes distintas que emergem, mas pela maneira como as partes se tornam inseparáveis [DELEUZE, 1991: 70], a associação de materiais inusitados revela o fazer da obra que liberta o projeto das amarras das tipologias propondo formas sem precedentes. Como diz Gehry:

"Eu estava interessado em fazer a velha casa parecer intacta dentro da nova, assim, do exterior seria possível perceber que a velha casa ainda estava lá e que alguém a embrulhou com novos materiais. Minha intenção era que a combinação das duas faria a casa velha mais rica e a nova mais rica ainda pela associação com a velha". [BLETTER, 1986: 32]

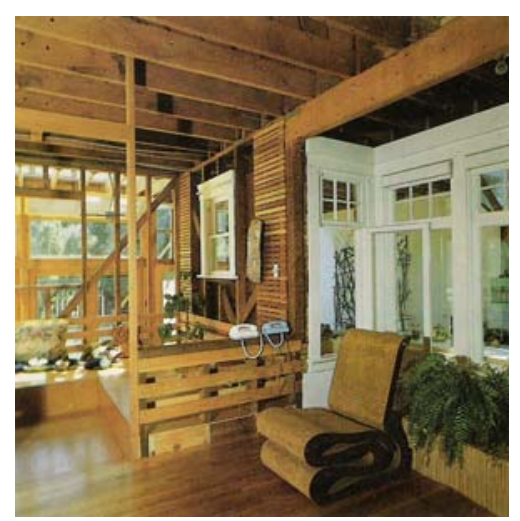

\section{Interior}

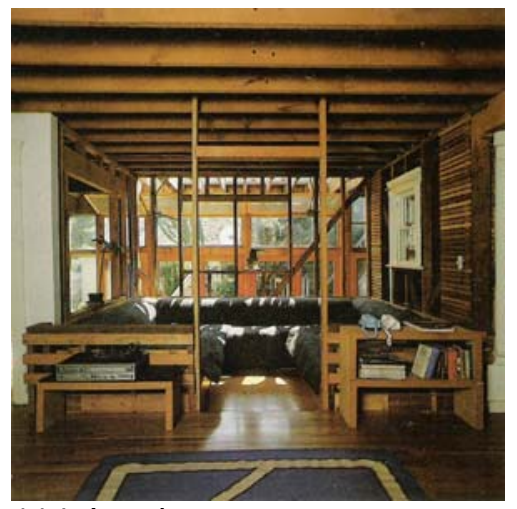

114. Interior

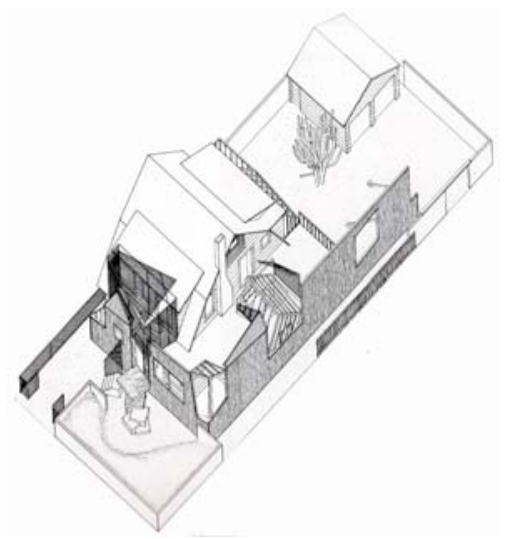

115. Axonométrica 
A pequena casa de arquitetura vernácula é envolta por uma segunda pele, uma casca amalgamada às suas entranhas como um organismo. A diferença entre o velho e o novo, a contradição entre usual e inusitado, como na dobra barroca provoca uma cisão que relança uma coisa sobre a outra, criando uma duplicidade, tensão nos dois lados que a dobra distingue, distendendo o de dentro para fora, o de fora para dentro [DELEUZE, 1991: 58-59]. Os materiais parecem dotados de forças plásticas e a obra, dobra, parece tomada por inflexões, turbulências e variações.

\section{UMA CITAÇÂO DE MILHÕES DE ANOS}

Gehry estava cansado de terceirizar os projetos complementares e a administração das obras e procurava uma maneira de resgatar o papel do arquiteto como mestre de obras, gerenciando a produção da arquitetura de ponta a ponta, do croquis ao acompanhamento da construção. Por outro lado, o arquiteto estava pronto para experimentar novas formas, formas mais complexas, libertando seus projetos das amarras da tipologia em busca de formas sem precedentes, como acontece em seus projetos nos últimos anos dos 80 [FRIEDMAN, 1999: 12]. Era preciso adaptar à produção da arquitetura e às limitações da construção os procedimentos encontrados empiricamente na gênese de suas obras.

Em 1989, contrata James Glymph, um experiente arquiteto para implantar em seu escritório a estrutura de gerenciamento que desejava. Para alcançar o objetivo de Gehry, seria necessário introduzir o uso do computador no escritório que, nessa época, contava com apenas dois computadores, um dedicado às tarefas administrativas e outro utilizado como processador de textos. O primeiro trabalho ao 
cargo de Glymph de ponta a ponta, foi o projeto para o complexo comercial.da vila Olímpica de Barcelona.

Parte desse projeto é o famoso peixe, conhecido como o 'peixe de Barcelona'. A forma intrigante remete à sua infância, quando todas as quintas-feiras pela manhã sua avó comprava uma carpa viva no mercado e a deixava nadando na banheira até a hora do jantar e ele tinha o dia todo para brincar com 0 peixe [HINES, 1986: 11-12]. Dollens [2002: 25] diz que a carpa nadava na memória de Gehry há muito tempo, e já havia aparecido em projetos de objetos e apareceria em obras subseqüentes. Mas a explicação de Gehry é de outra ordem:

"O peixe era uma espécie de gozação sobre as referências ao passado. Todo mundo estava citando antigos edifícios clássicos, assim decidi citar algo cinco milhões de anos mais antigo que a humanidade. Também era uma crítica ao antropocentrismo da arquitetura clássica, ao fazer referência literal ao corpo de um animal. Eu o vejo mais como um experimento com a cultura arquitetônica do que como um traço significativo de minha obra". [ZAERA-POLO, 1995a: 33]

As palavras de Gehry dão a medida de seu espírito provocador. Ele parece cansado do enfadonho movimento da história da arquitetura, de seus modismos, o que o leva a estar sempre atrás do novo, do diferente que transgride a regra. Há uma incrível foto sua atuando na produção de uma das performances que idealizou em que é praticamente impossível não achar que se trata do velho guerreiro Chacrinha, grande animador de programas de auditório da televisão brasileira por

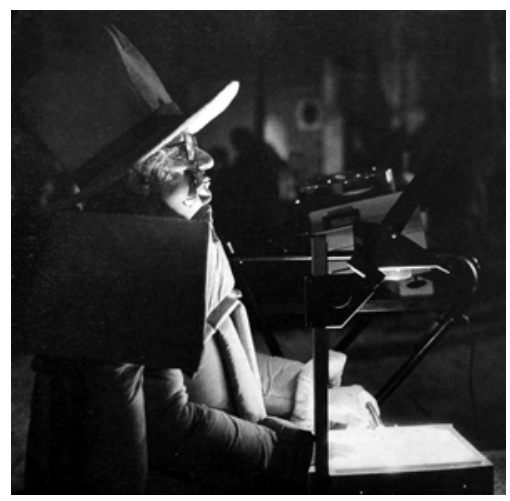

116. 'vim para confundir'. longos 30 e tantos anos. Muito além da jocosa semelhança da imagem, parece que o espírito que move Gehry é o mesmo que movia Chacrinha. "Não vim para explicar, vim para confundir", poderia ser o mote provocador de Gehry repetindo o velho 


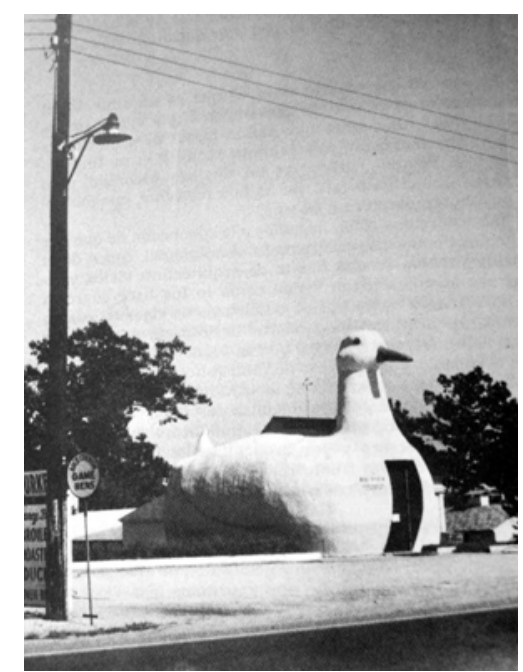

117. Arquitetura pato: Las Vegas.

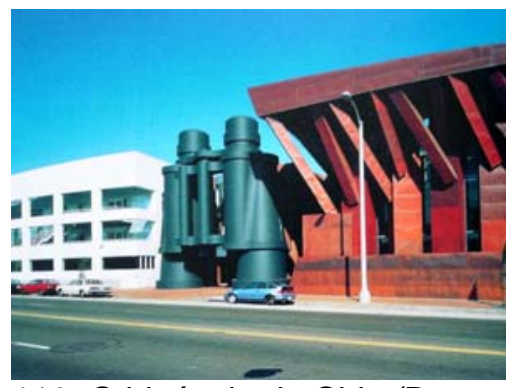

118. O binóculo da Chiat/Day em Venice, Califórnia, EUA
Chacrinha. O que aparenta uma postura irresponsável de entretenimento ou uma abordagem superficial da arquitetura, pode de fato ser encarada como uma das experiências mais significativas da arquitetura no final do século XX que principia a necessária renovação de seus fundamentos para o início de um novo século, tanto nos processos de concepção como nos procedimentos de construção da obra.

Segundo Hal Foster [2002], o mestre de obras (master builder) Gehry foi capaz de conciliar o que parecia inconciliável no pop, estrutura e imagem, contradição definida em Aprendendo de Las Vegas por Venturi [1978: 114 e ss.] como arquitetura pato, o edifício símbolo, imagem e arquitetura galpão decorado, estrutura em que se aplicam símbolos. A contradição entre o uso quase vernacular de materiais como a tela de alambrado e o compensado em sua casa e a construção quase escultórica de um binóculo gigante se combinam. Entre pensar o espaço e a forma a partir do material e a apropriação simbólica dos objetos, Gehry não privilegia nem a relação nem a imagem, fazendo emergir à superfície um enorme peixe que combina as duas coisas [FOSTER, 2002: 27-42].

\section{UM PEIXE EXPERIMENTAL}

Contudo, acima de todas as questões que rodeiam o peixe de Barcelona, o mais importante é que a postura experimental de Gehry, manifesta pela sua atração por materiais baratos e de uso comum no cotidiano que, aplicados construtivamente, adquirem valor, também se manifestará em relação ao uso das tecnologias informáticas, do suporte numérico-digital [DOLLENS, 2002: 23]. 
Segundo o relato no pequeno e valioso Digital Gehry de Bruce Lindsey [2001: 32-38], o arquiteto já estava há alguns anos às voltas com o projeto da sala de concertos da Disney sem encontrar a solução para viabilizar a construção das formas complexas que surgiam de seus croquis. Glymph, então, assume a tarefa de implementar o uso do computador no projeto do peixe de Barcelona. A princípio, Glymph recorre a William Mitchell, guru das tecnologias CAD (Computer Aided Design, em português projeto assistido por computador) para arquitetura, na época professor em Harvard. Com sua ajuda utilizaram um software chamado Alias para produzir um modelo 3D que, apesar da acuidade visual, não provia as informações necessárias para construir a superfície complexa do peixe. Em geral, os softwares de arquitetura trabalham em 2D apenas aproximando as formas sem correspondência com a escala real, não fornecendo informações fundamentais para a construção, como dimensionamentos, cargas e a precisão das relações de pontos estruturais, impedindo a conexão com o sistema CAM (Computer Aided Manufactoring, em português fabricação assistida por computador), passo considerado essencial por Glymph para construir aquela forma complexa.

Depois de dois anos, Gehry duvidava da possibilidade de usar o computador. Glymph percebe que a solução estaria na indústria automotiva e aeroespacial e parte a procura de outra solução. Encontra o software CATIA, software desenvolvido pela empresa francesa Dessault Systémes em parceria com a IBM. Para trabalhar com o CATIA traz como consultor Rick Smith, então desenvolvedor do CATIA na IBM. Smith desenvolveu o modelo 3D do peixe, usando os desenhos e maquetes feitos no escritório, aproveitando o total controle numérico e a descrição matemática das superfícies através de

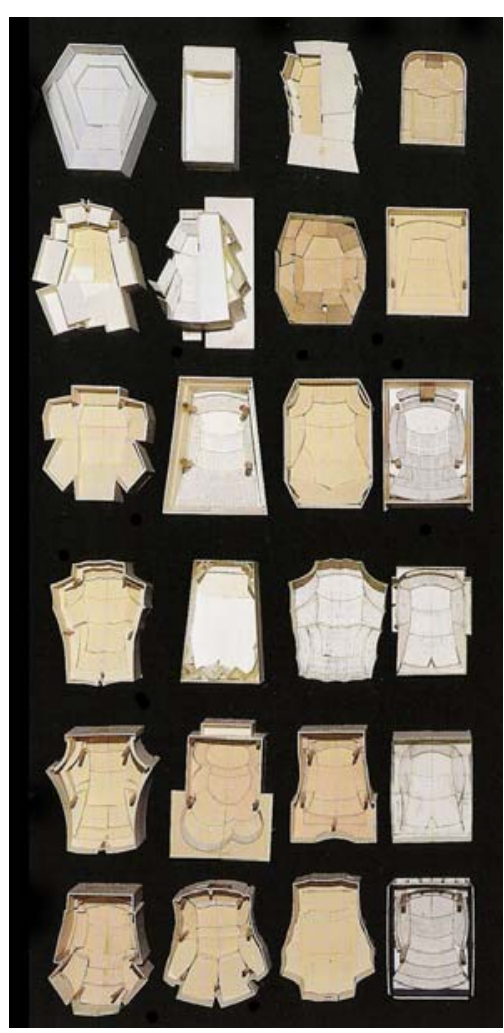

119. Disney Concert Hall: maquetes de estudo
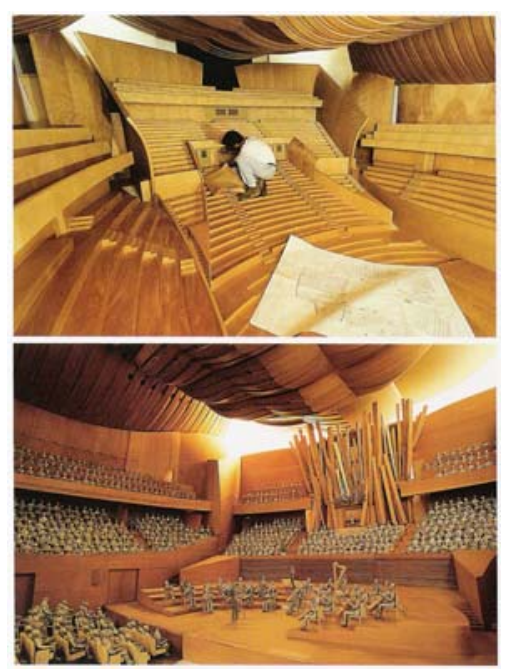

120. Disney Hall: maquete em grande escala. Experimentação. 


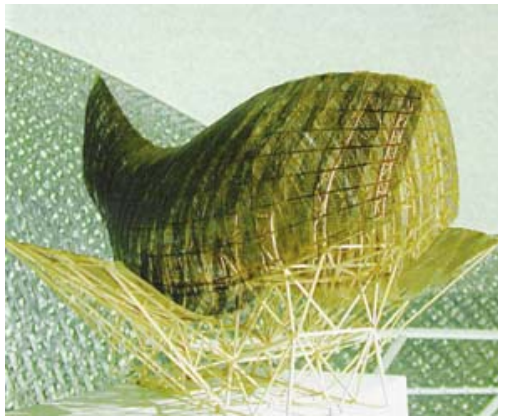

121. Peixe de Barcelona

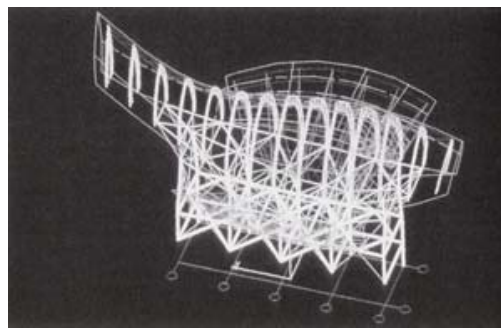

122. estrutura equações polinomiais do CATIA que permite literalmente construir o modelo tridimensional no suporte digital.

Da superfície derivou a estrutura de sustentação, o esqueleto metálico, mesmo sistema utilizado posteriormente no Museu Guggenheim de Bilbao (1991-1997) e no Experience Music Project de Seattle (1995-2000). O trabalho caminhou da pele para dentro, procedimento comum na indústria automotiva, ao contrário do projeto para Disney, que partia de dentro, das formas acústicas, para fora. A firma italiana contratada para a construção deveria construir um modelo em escala real para demonstrar que poderia de fato executar a obra. Falhou por seis vezes, pois cometia dois equívocos: trabalhava com os desenhos ao invés de trabalhar com os modelos digitais e partia da estrutura para a superfície. Smith teve que incorporar a equipe de construção, utilizando o mesmo procedimento adotado para construir o modelo digital.

\section{O PROCESSO DIALÓGICO: ENTRE O ANALÓGICO E O DIGITAL}

O peixe de Barcelona foi o primeiro projeto de Gehry finalizado totalmente em suporte digital, por meio do software CATIA e serviu como um modelo tridimensional em escala real, instalado no espaço público, como se fosse um estudo, a experimentação de um processo repleto de descobertas, de uma arquitetura que com o tempo viria a se transformar em inovação consistente [DOLLENS, 2002: 26].

O procedimento criativo de Gehry, bastante conhecido, se apóia na construção de inúmeras maquetes de estudo que procuram traduzir as formas complexas diagramadas em seus croquis. Talvez o grande mérito de James Glymph tenha sido 
encontrar o software capaz de se adaptar ao processo criativo de Gehry e não o contrário. Os diagramas que Gehry estava inventando eram cada vez mais complexos, praticamente impossíveis de serem expressos por meio do desenho técnico tradicional, à mão. O último projeto feito à mão no escritório de Gehry foi o museu Weisman na Universidade de Minnesota (1990-1993), em que as formas ainda são fragmentos de sólidos calculados pela geometria descritiva representados manualmente.

Segundo Glymph [ZAERA-POLO, 1995b: 152-155], o computador não poderia simplesmente servir para construir maquetes eletrônicas, mas deveria ser o instrumento de mediação que se insere no processo de modo dialógico, contribuindo para a concepção tanto quanto para a construção. Assim, o programa teria que simular a forma em três dimensões, resolvendo problemas complexos de sua construção geométrica, especificando dimensões, quantificando materiais e custos, como se fosse um programa de fabricação. O CATIA permitiu melhorar o procedimento de Gehry e se inseriu como uma luva no movimento constante entre os croquis, os modelos tridimensionais e as simulações digitais, espaço para descobrir a arquitetura entre o analógico e o digital [TEIXEIRA, 2005]. Para ele, o output, a saída, o resultado desse processo deveria ser o próprio edifício eliminando as etapas intermediárias de desenhos impressos.

Depois de vários projetos desenvolvidos com o CATIA, A Dessault Systémes passou a trabalhar na adaptação de uma versão especial do CATIA especificamente para o escritório de Gehry. O trabalho do arquiteto levantou questões que fizeram com que a empresa pudesse melhorar o software. Segundo 
Friedman [1999: 17], no futuro os arquitetos desenharão seus próprios softwares e Gehry está a meio caminho disso.

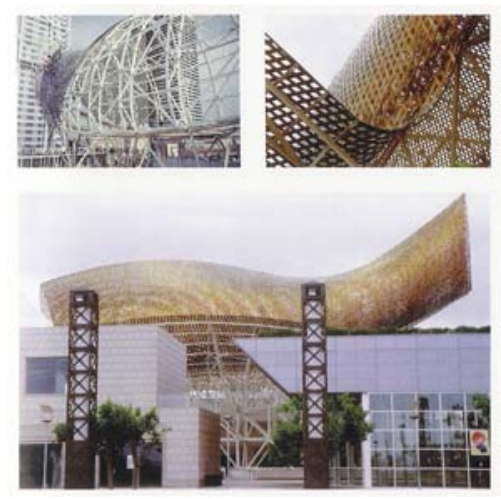

125. vistas do peixe
A experiência do peixe foi necessária para mostrar a Gehry as potencialidades do suporte digital como parte do procedimento criativo. Foi a descoberta que o liberou para criar formas cada vez mais complexas, sabendo que poderia digitalizar qualquer modelo 3D para fazer a simulação digital. Ele mesmo diz [GEHRY, 1999: 48-51] que se sentia mais livre para experimentar com as formas em pequenos modelos que depois poderiam ser digitalizados pelo software que faz todos os cálculos necessários para a construção. É o retorno do master builder tão almejado por ele.

\section{AS DOBRAS EM MOVIMENTO DIGITAL}

O desejo de Gehry por construir formas cada vez mais complexas [GEHRY, 1999: 48], provavelmente tem origem no seu gosto por velejar [ZAERA-POLO, 1995a: 31] e observar as formas curvas das velas que inflam e dobram ao sabor da constante mudança de direção dos ventos:

"Quando você está velejando o vento pega a vela, que fica muito tensionada, resultando numa bela forma. Então, ao fazer uma volta, o vento está contra, num certo ângulo e você vira para pegá-lo e ele está dos dois lados da vela. Nesse momento a vela adeja, vibra, drapeja e então ela adquire uma qualidade de rara beleza". [GEHRY, 1999: 43]

Quando se trata de formas dessa ordem de complexidade, conseguir uma tal fidelidade entre a concepção da obra e sua realização final parece tarefa impossível. Contudo, como observa Antonino Saggio, a obra de Gehry toma o caminho oposto: 
"A arquitetura de Gehry se parece mais e mais com seus

croquis, mas os modelos digitais muito mais: eles

assimilam a possibilidade de uma inteligência, uma

mutação, uma mudança muito maior do que a

interpretação, mesmo que de forma brilhante, dos signos

e sonhos de um gênio." [SAGGIO, 2001:9]

Da metáfora das velas, uma relevante interpretação das formas criadas por Gehry e sua relação com o digital é feita por Michael Sorkin [1999: 27-36]. Embora usando como referência o cinemático, o cinema, para Sorkin a arquitetura de Gehry está numa condição de animação. Seus croquis são diagramas do movimento e o computador não é uma ferramenta de criação, mas um tradutor, um instrumento para pegar a curva em movimento, e não para inventá-la. A obra de Gehry não seria mais música congelada, mas movimento que se congela. Se o movimento moderno usava a metáfora dos navios que navegavam ao longo de seus extensos eixos, Gehry dispersa o sentido de direção e coloca esse movimento na condição de animação. Animação que remete a dinâmico:

"O modelo eletrônico é por sua natureza extremamente diferente de uma maquete tradicional uma vez que é um todo vivo, interativo (e em certos aspectos inteligente). Enquanto na maquete a informação é estática, no modelo digital todos os bits de informação estão interconectados dinamicamente. Nesse sentido, o modelo eletrônico é um recurso para estudar, testar, simular e construir. Não garante que o projeto seja bem sucedido, mas é o passo adiante mais importante na tarefa de projetar desde a descoberta da perspectiva." [SAGGIO, 2001: 6-7]

O digital toma lugar na obra de Gehry e amplia exponencialmente o procedimento de criação segundo a dobra de Deleuze, do retorno da linguagem sobre si mesma, num processo de experimentar para descobrir. $O$ digital relança 


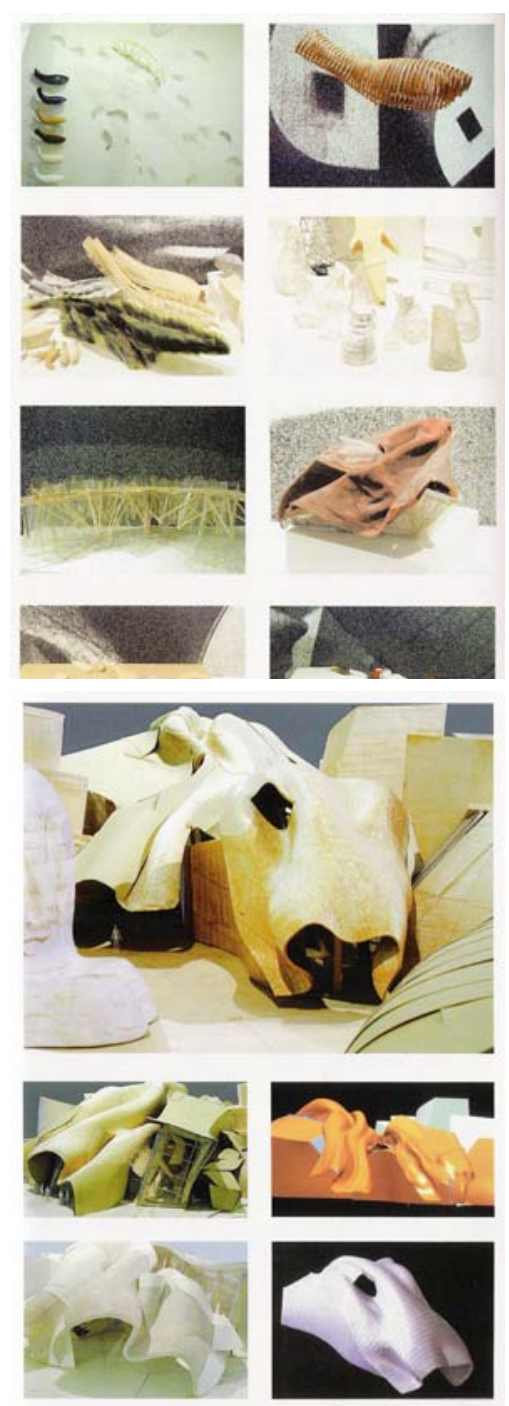

127. Casa Lewis: maquetes de estudo. a idéia da obra sobre o modelo tridimensional que se transforma e assim sucessivamente, dobra sobre dobra, uma coisa sobre a outra, sempre um retorno sobre si. O pensamento se traduz na matéria da dobra do suporte digital, matéria-fluxo que deve ser seguida. Experimentar para descobrir uma arquitetura que, segundo Valéry [1998: 35], como toda obra de arte deveria nos ensinar que não tínhamos visto o que vemos. "Uma nuvem, uma terra, um navio, são três maneiras de completar uma certa aparência de objeto que surge no horizonte sobre o mar." [VALÉRY,1998: 37]

A arquitetura de Gehry, que se dobra entre o analógico e o digital, é esse objeto que veleja, de forma inusitada, por oceanos ainda não vistos. Parece que Deleuze a descreveria assim:

“Denominemos objéctil esse novo objeto. (...) Trata-se de uma concepção muito moderna do objeto tecnológico: ele nem mesmo remete ao início da era industrial, quando a idéia de padrão ainda mantinha uma feição de essência e impunha uma lei de constância (...), mas remete, isso sim, a nossa situação atual, quando a flutuação da norma substitui a permanência de uma lei, quando o objeto ocupa lugar em um contínuo por variação, quando a prodútica, a máquina que funciona por controle numérico, substitui a prensa. Pelo seu novo estatuto, o objeto é reportado não mais a um molde espacial, isto é, a uma relação forma-matéria, mas a uma modulação temporal que implica tanto a inserção da matéria em uma variação contínua como um desenvolvimento contínuo da forma. Na modulação 'nunca há interrupção para desmoldagem, porquanto a circulação do suporte de energia equivale a uma desmoldagem permanente; modulador é um molde temporal contínuo...Moldar é modular de maneira 
definitiva; modular é moldar de maneira contínua e perpetuamente variável'." [DELEUZE, 1991: 38]

O Guggenheim de Bilbao representou a oportunidade para aperfeiçoar os procedimentos híbridos entre analogias e digitalizações. A forma do edifício parece que respira em analogia ao movimento das velas sob as forças imprevisíveis dos ventos. Sua realização só foi possível utilizando os recursos do software Catia, dada a complexidade do edifício e a quantidade de informação traduzida em desenhos. Foram 50.000 desenhos e 60.000 horas de computação. Todos os elementos da estrutura de $24.000 \mathrm{~m}^{2}$ são diferentes entre si, nenhum deles se repete como na produção seriada industrializada. A produção informatizada permitiu produzir em série com variações. Além disso, todos os cálculos de áreas e custos foram realizados e simulações foram feitas para antecipar problemas estruturais, acústicos, de conforto e iluminação.

Gehry projeta a partir de desenhos livres, gestos que procuram uma forma. Desses croquis, modelos tridimensionais são construídos, podendo gerar outros modelos ou ainda ser digitalizados. O processo é como um diálogo entre cada uma das instâncias do projeto, nenhuma delas ainda definitiva, cada uma sugerindo encaminhamentos e solicitando escolhas. Gehry usa outros softwares, além do Catia, de acordo com as necessidades surgidas no processo. Pode, por exemplo, usar o Autocad para fazer um bloco de plantas, ou pode usar o Rhino para construir uma maquete a partir de diagramas digitais [Lindsey, 2001].

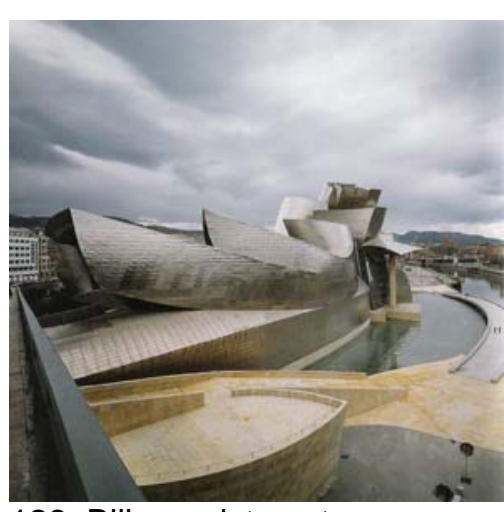

128. Bilbao: vista externa

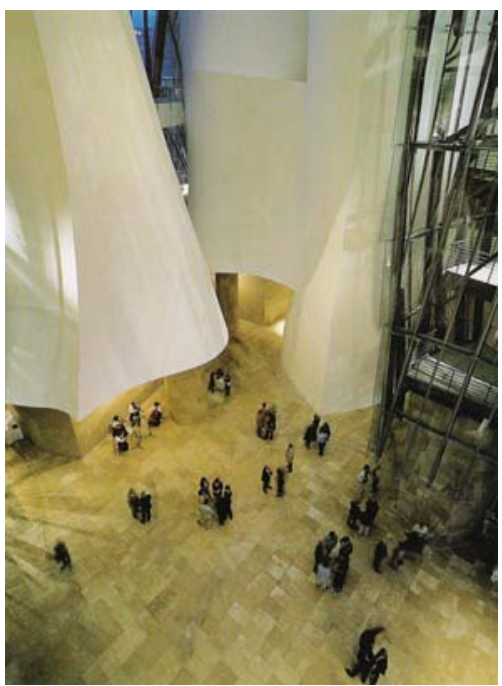

129. vista interna

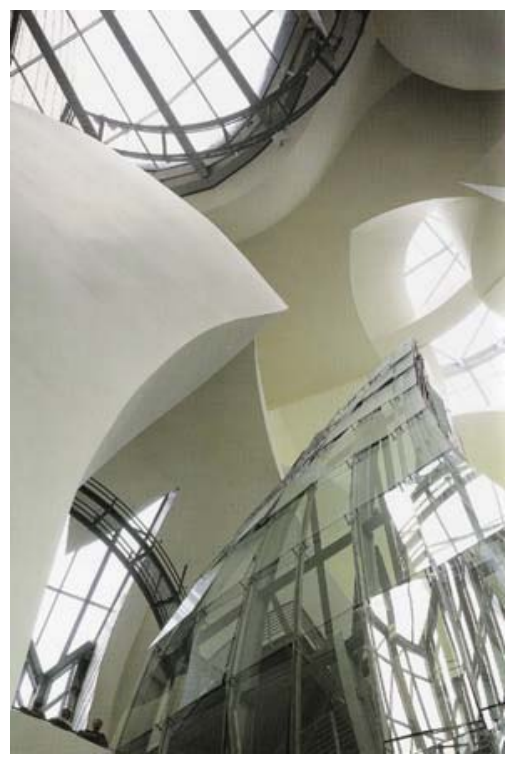

130. interior: dobras 


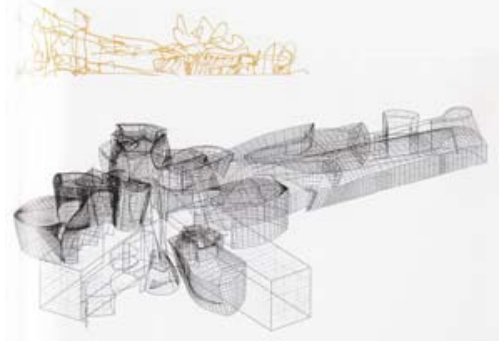

131. croquis e wire-frame

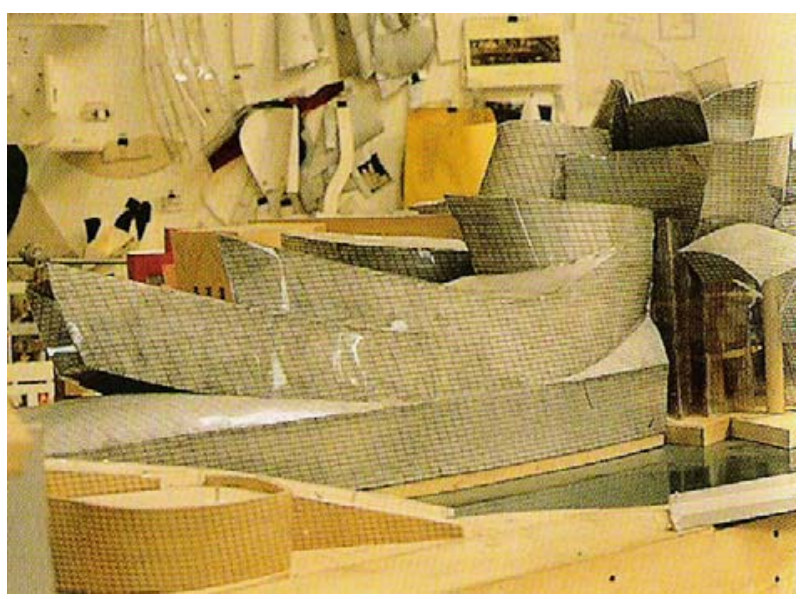

132. maquete de estudo
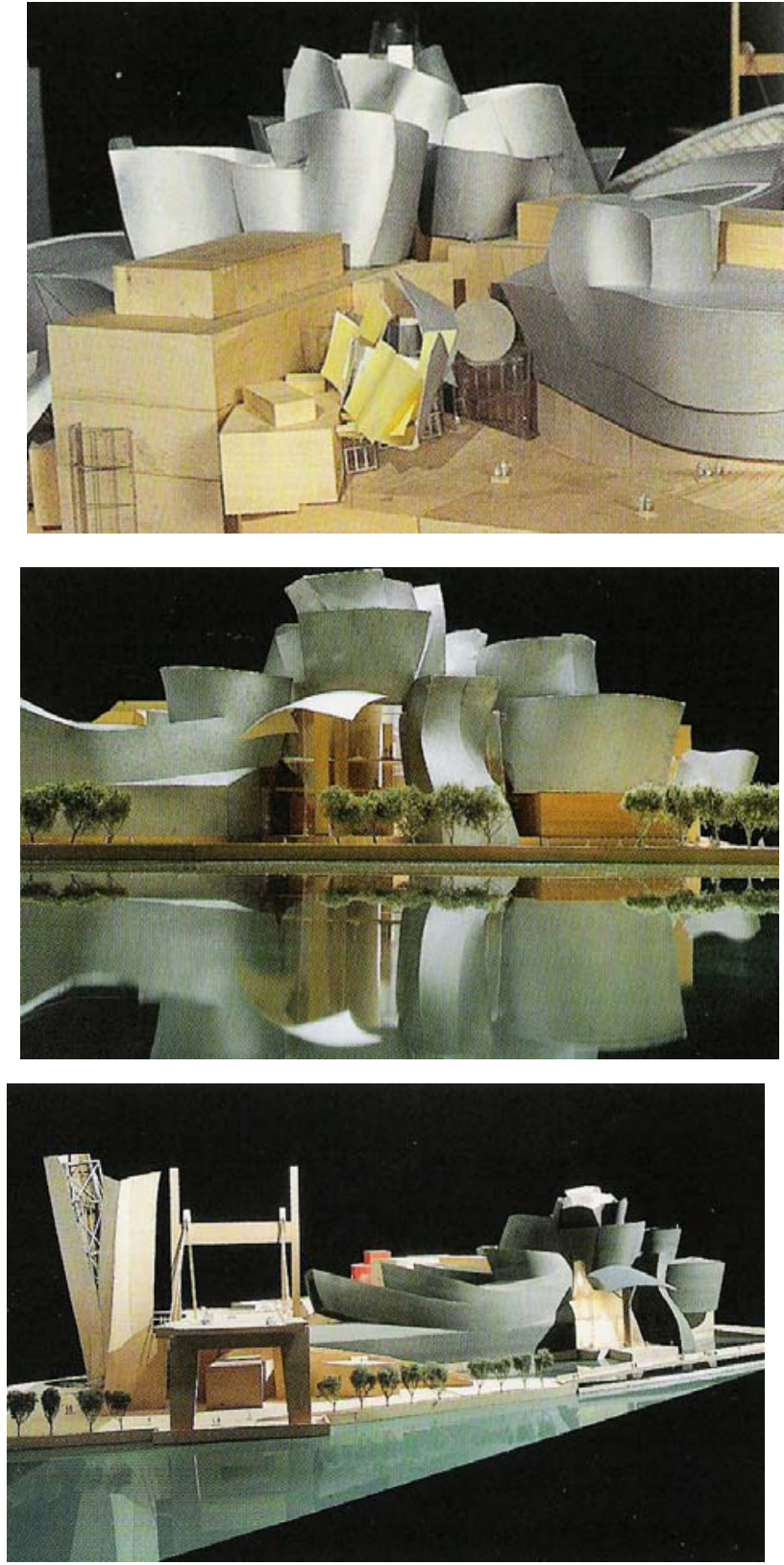

136 a 138. maquetes
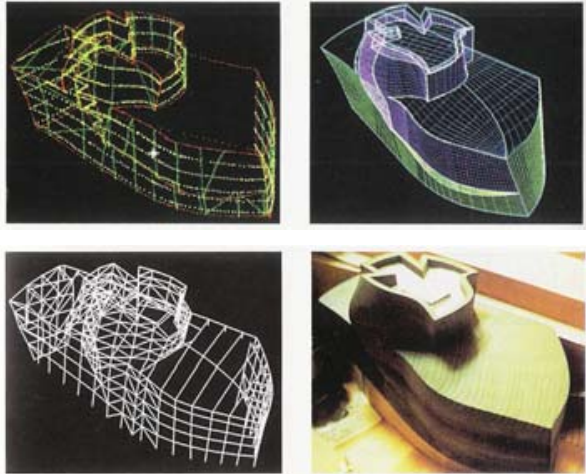

133. construção digital de um volume
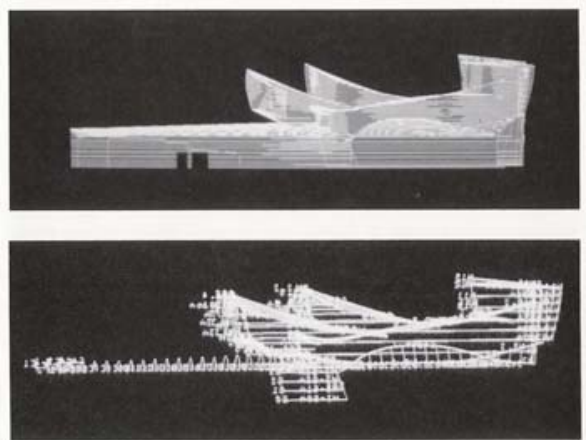

134. Cortes digitais

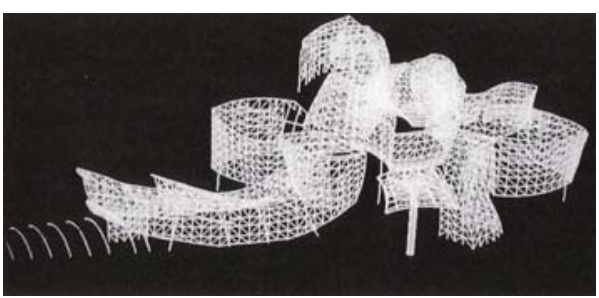

135. wire frame 
Paul Allen, o fundador da Microsoft amante do rock e fã de Jimi Hendrix, queria dedicar um museu experimental e interativo à música. Surgiu, então o projeto do Experience Music Project (EMP). Segundo ele, o arquiteto deveria ser capaz de traduzir as qualidades musicais do rock, especialmente do som da guitarra de Hendrix, em forma e espaço. Rara experiência de Gehry com cores, cada uma remetendo a ícones do rock, como o púrpura para a guitarra de Hendrix (purple haze), o dourado para Les Paul e o azul para a guitarra Fender. Gehry depois mencionaria que procurou evocar o rock sem ser literal.

Devido às suas curvas complexas e variedade de matérias, no EMP, análises Gaussianas foram usadas exaustivamente. Um conjunto de funções matemáticas é aplicado digitalmente aos componentes do edifício (principalmente aos painéis de dupla curvatura) para avaliar se o comportamento da curva com determinado material não apresenta problemas. O modelo digital indica cores para cada comportamento e se há um problema é possível redesenhar a curva. O recurso, aliado à construção de modelos tridimensionais permitiu, além de racionalizar a obra e otimizar os custos, aperfeiçoar a curvilinearidade complexa dos projetos de Gehry.

Outra interessante experiência foi a utilização de uma shape grammar, desenvolvida por Dennis Shelden (como parte de seu doutorado no MIT) para testar as soluções formais e seu desempenho plástico. Uma shape grammar usa a informação do modelo digital multiplicando exponencialmente as possibilidades de variação e combinação no projeto. No EMP, a relação analógica (tradução da forma) com o digital pavimenta a continuidade até a obra. Todas as etapas da construção

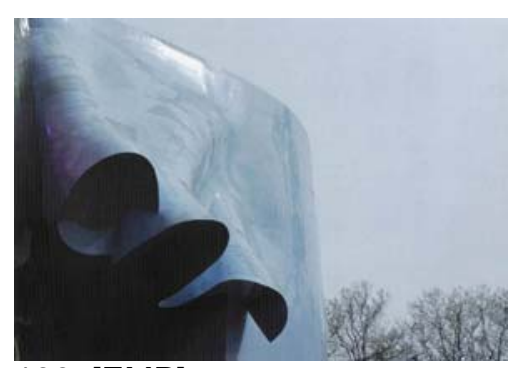

139. [EMP]

Experience Music Project Seattle, Washington, EUA

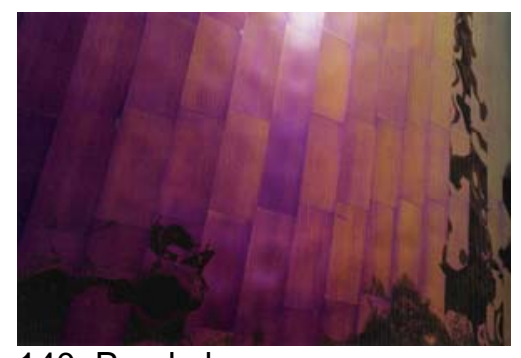

140. Purple haze

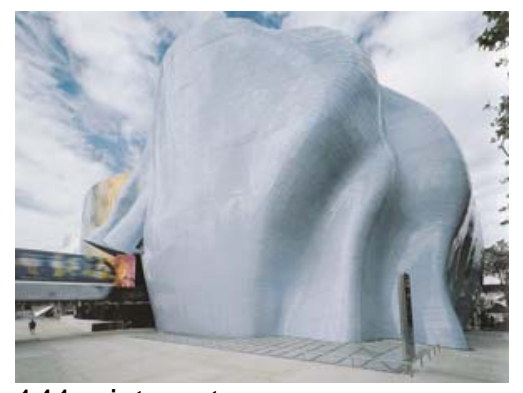

141. vista externa 


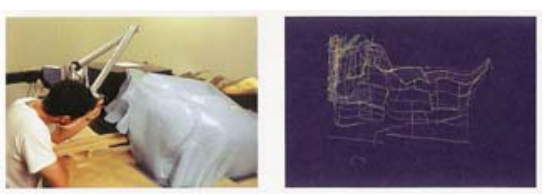

142. digitalização de maquete

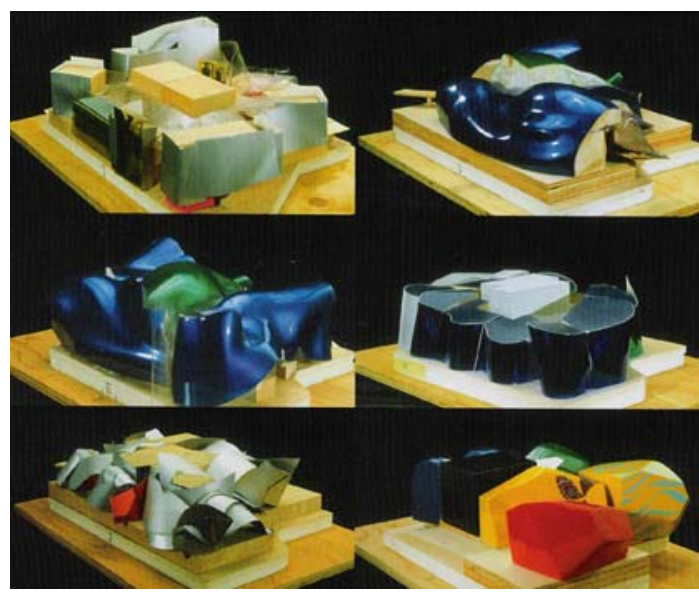

143. maquetes de estudo
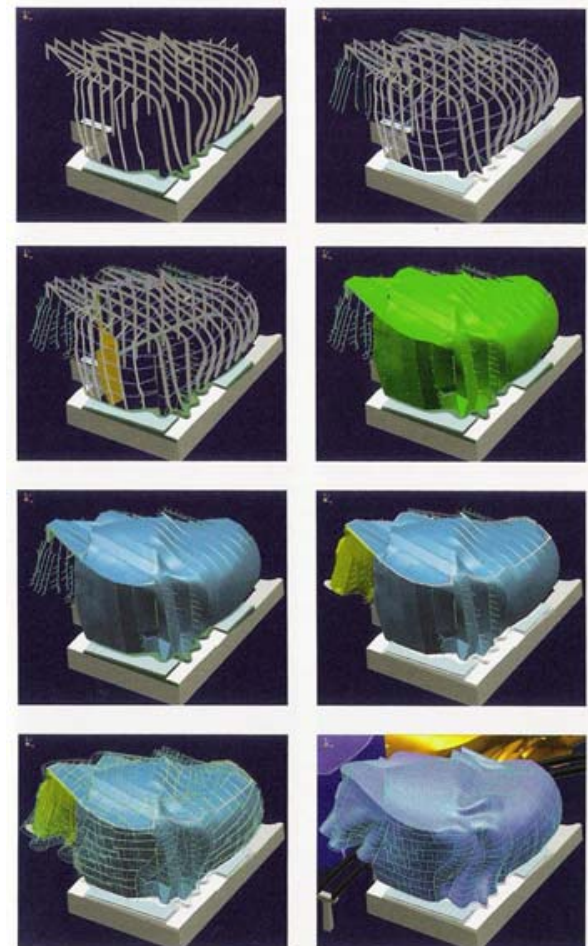

145. projeto da superfície

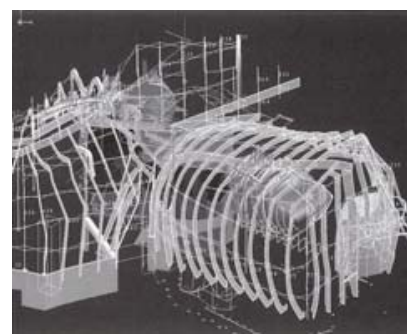

146. estrutura

144. estrutura e superfície

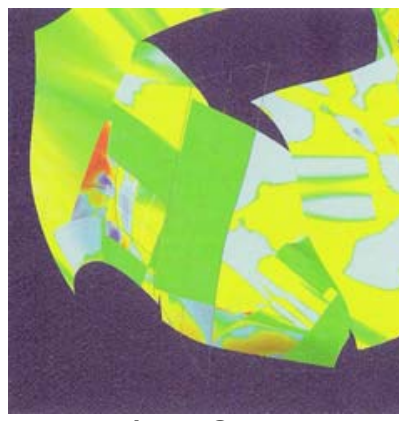

147. análise Gaussiana

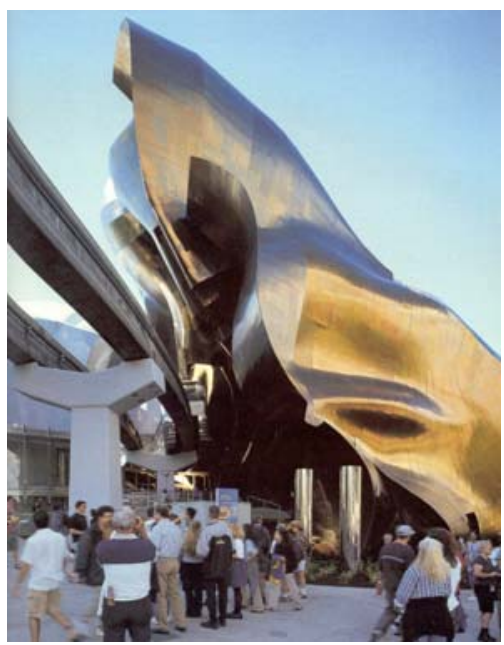

148. vista externa

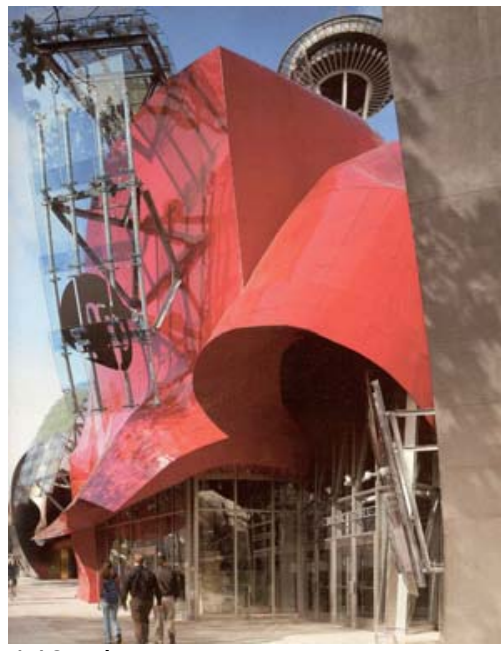

149. vista externa
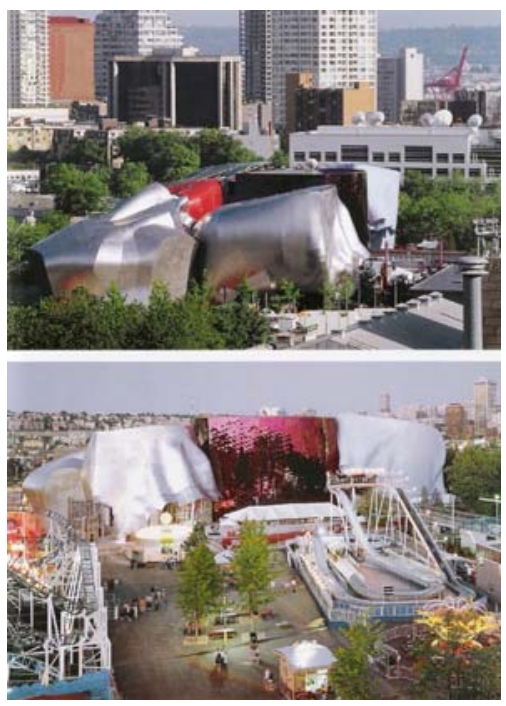

150. vistas 
O procedimento da dobra também é utilizado pelo grupo holandês NOX, liderado pelo arquiteto Lars Spuybroek. Um exemplo seria D-Tower, projeto realizado em Doetinchem, Holanda (1999-2004). Objeto midiático híbrido, sistema de relações interativas, a torre representa a parte física do projeto que conta com um website e um questionário. O edifício está conectado ao website que abriga um questionário que permite aos habitantes da cidade expressar seus sentimentos diários de raiva, amor, felicidade e medo. As respostas são traduzidas em diagramas no website. As quatro emoções são representadas pelas cores verde, vermelho, azul e amarelo, presentes na iluminação da torre que muda de acordo com o sentimento predominante a cada dia.

A estrutura / forma é definida através de modelos experimentais construídos à semelhança das curvas catenárias, de ponta cabeça. Impossível não lembrar de Gaudí e de seu procedimento experimental. Esse modelo gera uma forma de dupla curvatura retorcida. À medida que ganham altura, os pilares da torre vão se transformando nas superfícies de cobertura.
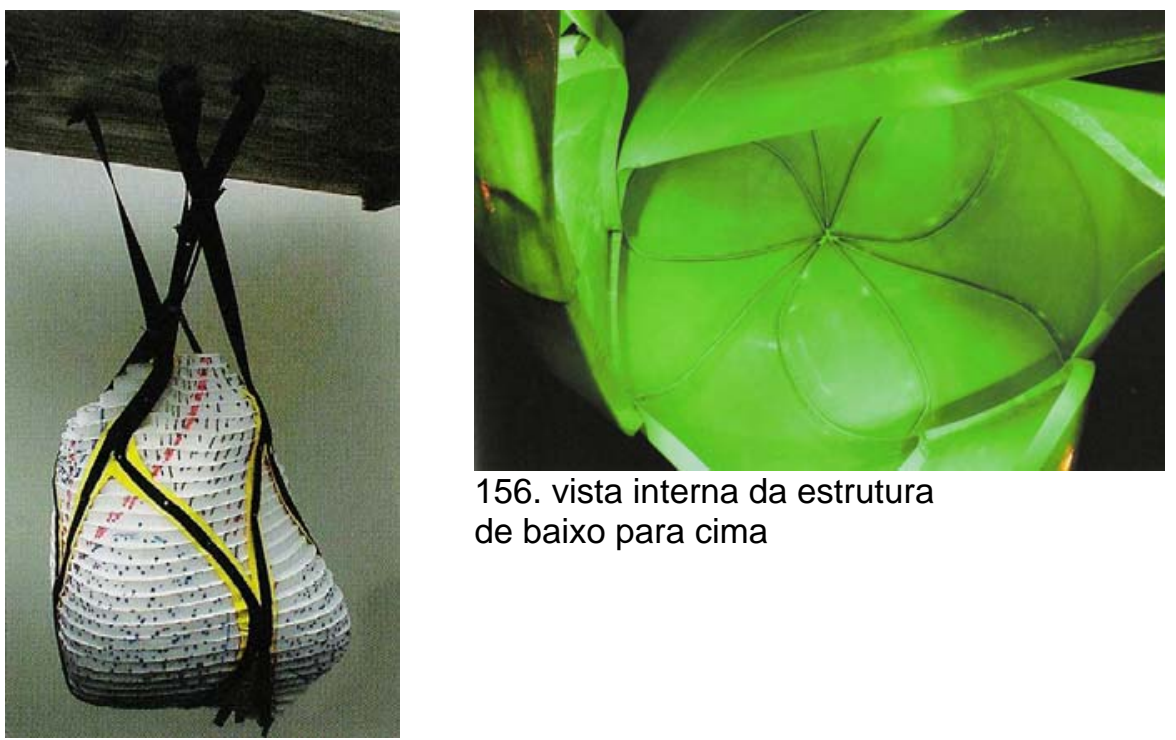

156. vista interna da estrutura de baixo para cima

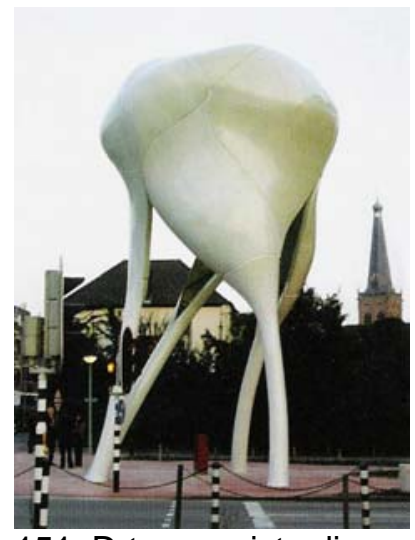

151. D-tower: vista diurna
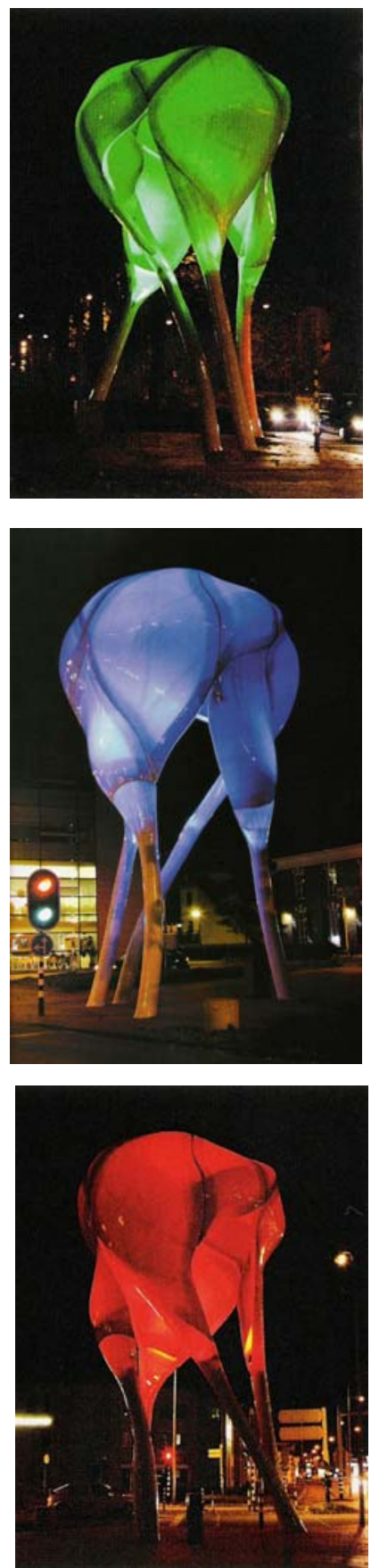

152 a 154 vistas notırnas 


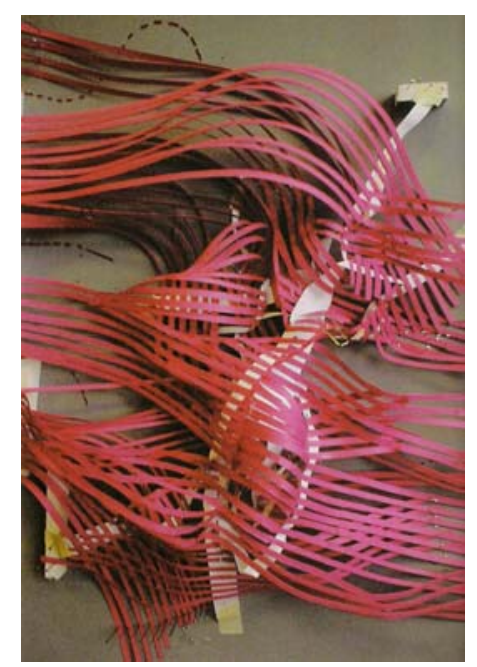

157. diagrama 3D: estrutura
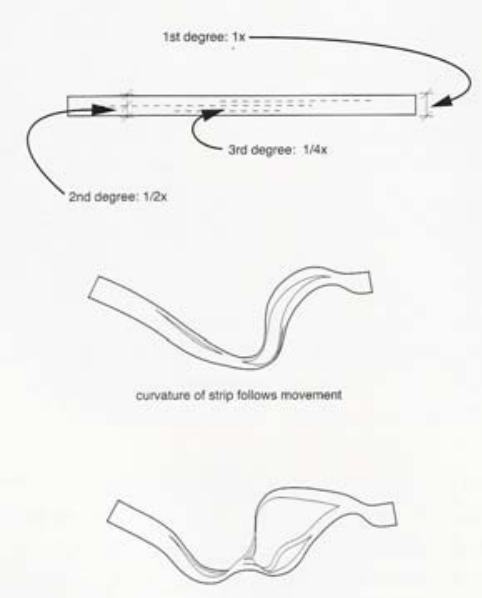

159. dobras

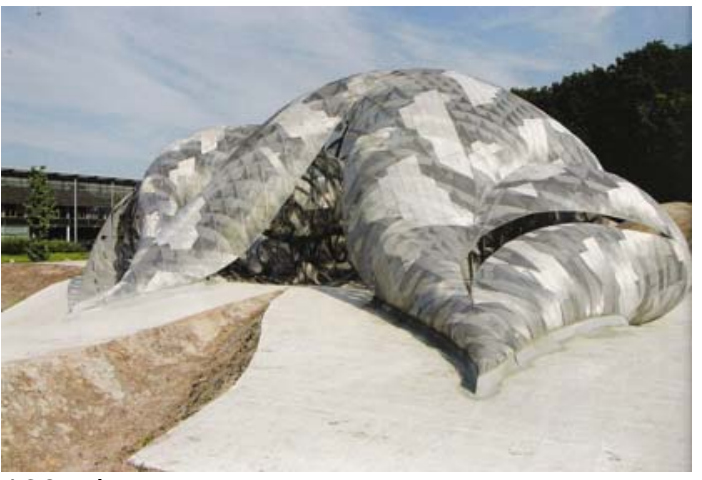

160. vista externa

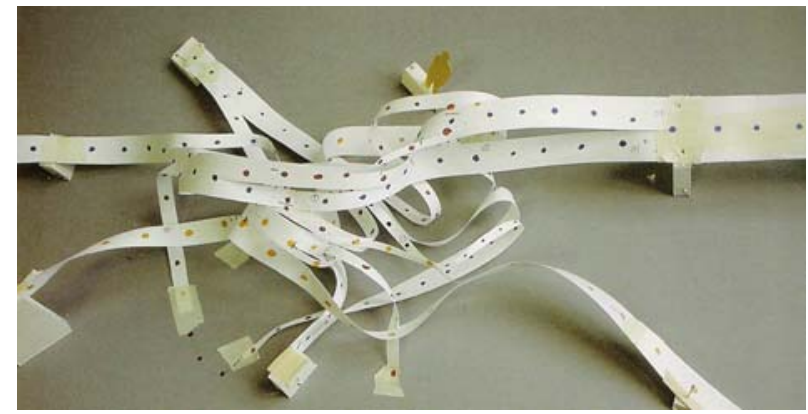

158. diagrama 3D: gênese

Outro projeto de Nox é Son-o-house, também realizado na Holanda, em Son Em Bruegel (2000-2004). A estrutura é ao mesmo tempo arquitetura e música, lugar de abrigo e convivência que gera sons derivados da relação dos usuários com o espaço. O comportamento dos usuários modifica a freqüência e o tempo das composições pré-programadas resultando em sons que representam a memória do espaço.

O projeto parte da leitura de movimentos cotidianos numa casa, inscritos através de cortes em tiras de papel. As tiras são coladas umas às outras formando curvas que, conectadas, compõem uma superfície auto-portante. São curvas, inflexões e dobras que se desdobram sobre si mesmas, formando um sistema dinâmico análogo aos movimentos de pessoas numa casa. Adaptações foram feitas no modelo para ajustar a superfície formada pelas tiras até se transformar em sistema estrutural, depois digitalizado e calculado como estruturas em forma de arco.

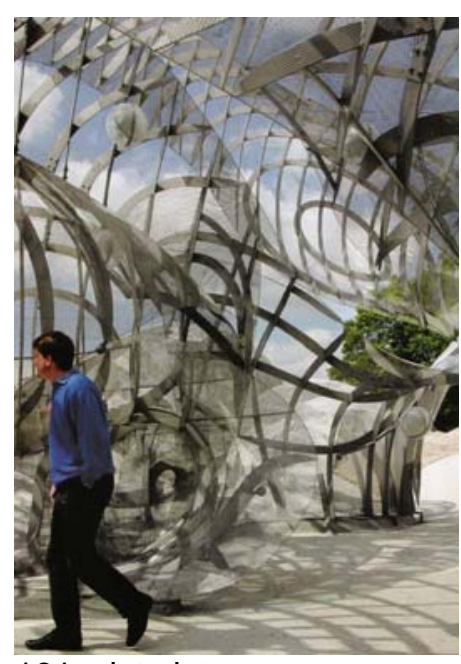

161. vista interna

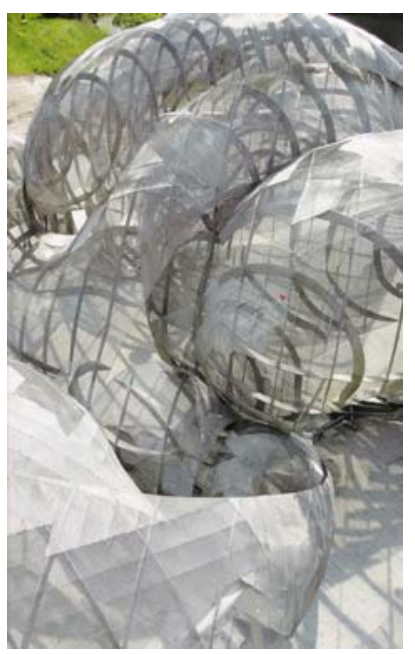

162. vista do fechamento 
Em Gehry, o vento que incide sobre as velas revela formas em constante mudança, e é referência do movimento traduzido, por analogia, em volumes e espaços dinamicamente drapeados, insuflados, inspirados. A tradução digital que viabiliza a concretização de formas do movimento serve de partida para concepção da forma animada de Greg Lynn [1998], onde traça as linhas fundamentais da tecnologia digital como matéria do movimento. O computador é o espaço da virtualidade que possibilita a criação digital de uma arquitetura na dinâmica do movimento.

"As formas de uma arquitetura concebida dinamicamente podem ser desenhadas associando forças e movimentos do virtual, mas isso não implica que $\mathrm{a}$ arquitetura altere sua forma. $\mathrm{O}$ movimento quase sempre envolve o paradigma mecânico de múltiplas posições discretas, ao passo que o movimento virtual permite que a forma ocupe continuamente uma multiplicidade de possíveis posições mantendo a mesma forma". [LYNN, 1998: 10]

Fazendo parte dessa primeira geração de arquitetos digitais de nascença, Greg Lynn completou sua formação trabalhando no escritório de Peter Eisenman, que em meados dos anos 90 passou a aplicar suas teorias no desenvolvimento de projetos em suporte digital. O que há de interessante em Lynn são suas indagações sobre a natureza do material com que trabalha que o levam a definições do suporte digital como espaço qualificado por uma série de atributos e propriedades que abrem possibilidades para procedimentos singulares. Essa abordagem do suporte digital como espaço é decorrência de um pensamento que se apropria de sua lógica, engendrando procedimentos para experimentação de suas potencialidades como se fosse matéria. 


\section{ESPAÇO ANIMADO}

Para Lynn, animação não se confunde com movimento. Enquanto movimento implica deslocamento e ação, animação implica evolução, transformação ocasionada por forças geradoras dinâmicas, que também se transformam. Animação sugere vida, crescimento, vitalidade, virtualidade. É um grande problema para os arquitetos, pois estes precisam trabalhar com a estática, com a permanência, com o inerte. É preciso desafiar esses pressupostos relacionando a arquitetura com modos de organização dinâmica, no sentido de avançar e ampliar as percepções da potencialidade da disciplina [LYNN, 1998: 9].

$\mathrm{Na}$ arquitetura tradicional, o espaço da gênese do projeto, independente do suporte, é neutro, baseado nas coordenadas cartesianas. Em outros campos de projeto o espaço da gênese é considerado como ambiente relacional, vivo. Por exemplo, no design naval, as propriedades de fluidez, turbulência e densidade da água são consideradas para que um casco de barco seja concebido se movendo sobre a água. A forma do casco antecipa a mobilidade enquanto permanece inalterada. As forças desse contexto contribuem para o projeto da forma do casco de um veleiro que guarda múltiplos vetores de fluxo e movimento em seu desenho, pois deve navegar sob uma variedade de condições em constante mudança. É uma topologia que incorpora uma multiplicidade de vetores, forças, uma multiplicidade de tempos numa única superfície contínua. Se a topologia lida com a continuidade das transformações, o arquiteto não lida mais com a forma, mas com deformações e informações [MASSUMI, 1998: 16; PONGRATZ, 2000] 
A animação se incorpora ao projeto e à forma e é definida pela co-presença de movimentos e forças no processo de concepção. A forma é definida por múltiplas interações vetoriais que se desdobram de modo contínuo e aberto. Ao invés do espaço cartesiano abstrato e neutro para projetar sobre o plano bidimensional, o suporte digital configura um contexto, um espaço abstrato ao mesmo tempo concreto, ativo, em que a forma se desenvolve em meio a correntes de forças que podem ser armazenadas como informações na configuração do projeto. O projeto de arquitetura está imerso em fluxos dinâmicos de um espaço que é meio para simular a forma. Espaço digital definido como virtual, uma vez que o projeto é um diagrama que pode ser atualizado de inúmeras maneiras conforme as configurações e informações inseridas no meio e suas relações com o desenvolvimento da forma [LYNN, 1998: 10-11].

"Negligenciada por arquitetos, a virtualidade implica forças e variação. A arquitetura convencional é concebida num espaço idealizado, dimensional e estático, definido por pontos fixos das coordenadas cartesianas. Vetores cujas trajetórias são relativas a outros objetos, campos, fluxos definem a forma num espaço ativo de forças e movimentos. Esta mudança de um espaço passivo de coordenadas estáticas para um espaço ativo de interações implica a mudança da pureza autônoma para a especificidade contextual". [LYNN, 1998: 11] 
O espaço do suporte digital não está submetido às leis da geometria euclidiana nem às coordenadas do espaço cartesiano. Os objetos nesse espaço são afetados por campos de influências que variam no decorrer do tempo. Uma posição no espaço só pode ser calculada como fluxo vetorial, de modo provisório, com a propriedade de desdobrar continuamente multiplicidades. Deleuze chamava a atenção para Leibniz, que considerava uma força como um virtual em curso de atualização, tanto quanto espaço em que ela se desloca [DELEUZE, 1996: 51]. Os modelos digitais são flexíveis, mutáveis, modulando séries de relações. Seus volumes são superfícies topológicas definidas por vetores $U$ e $\mathrm{V}$, onde predominam as transformações, as deformações em tempo real, representações da matemática topológica. [LYNN, 1998: 15-18]

De fato, o suporte digital é um sistema relacional, sua lógica é a das geometrias não-euclidianas. Essa natureza do espaço digital, confrontada com o espaço bidimensional e plano do suporte de papel, trará conseqüências significativas para a criação da arquitetura [DAVIDSON 1997; JENCKS 1997a; MASSUMI 1999]. Talvez a idéia de espaço que mais se aproxime para compreender o digital seja o espaço geométrico de Riemann, conceito que influenciou o desenvolvimento da teoria da relatividade de Einstein. Riemann postulou que no lugar do plano da geometria euclidiana, o espaço seria uma superfície curva [EVES, 1958: 52-72]. Os espaços da geometria de Riemann são heterogêneos, compostos por partes que quando em relação se redefinem. As relações que podem ser chamadas de táteis, em variação contínua, são abertas, 
podendo ser definidas por uma infinidade de maneiras [Deleuze, 1997b: 190-195].

Em sua concepção lógico-matemática da arquitetura, Lynn levanta três propriedades de organização fundamentais e inerentes ao espaço digital: topologia, tempo e parâmetros. Entidades topológicas são multiplicidades, pois não são compostas de pontos discretos, mas por fluxos contínuos de valores relativos. A topologia é caracterizada por superfícies flexíveis, compostas por splines. Splines constroem superfícies compostas por redes de curvas. Splines são vetores com pesos pendurados, semelhantes às curvas catenárias modeladas por correntes. A diferença é que as splines acomodam os pesos num espaço livre da gravidade. Os vértices de controle, pontos onde os pesos são pendurados são locados em coordenadas $X$, $Y, Z$. Apesar disso, a spline flutua como uma corrente fluída entre uma constelação de vértices de controle pesados e qualquer posição ao longo dessa série contínua só pode ser definida em relação a toda a seqüência. A forma de uma spline é resultado do número de controladores em cada região do fluxo [LYNN, 1998: 20-22].

Por ser um fluxo vetorial através de seqüências de pontos, splines são por definição multiplicidades contínuas. A multiplicidade é uma coleção de componentes que não podem ser reduzidos a uma entidade singular nem a um conjunto de múltiplas entidades. A multiplicidade não é uma nem muitas, mas uma reunião contínua de singularidades heterogêneas que possuem tanto qualidades comuns de continuidade quanto qualidades particulares de heterogeneidade [LYNN, 1998: 23]. Segundo Deleuze [1997b: 190-195], a formulação matemática 
do conceito de multiplicidade por Riemann foi um acontecimento decisivo. Começava aí a abertura para a relatividade do espaço, que permitia comparar medidas, distâncias, grandezas, intensidades feitas de diferenças que, se divididas, cada parte se apresentava como distinta. São dois tipos de multiplicidade: a multiplicidade numérica, material e atual que implica o espaço como condição: a distância é um conjunto de diferenças ordenadas, que se envolvem umas nas outras; e a multiplicidade qualitativa que implica a duração, cada divisão do movimento difere: coexistência virtual do um e do múltiplo, nem um nem múltiplo, mas uma multiplicidade [ALLIEZ, 1996: 21-22].

A inflexão, ou curvatura contínua é a incorporação do tempo e do movimento na forma. A curvilinearidade, segundo Lynn [1993], é uma forma de organização mais complexa que a linearidade porque integra múltiplas entidades e porque expressa atributos vetoriais, dinâmicos. Curvatura é o modo de integrar entidades em interações complexas em uma forma contínua. As inflexões nessa curva indicam velocidade e direção e portanto tempo. As formas topológicas resultam de desdobramentos dinâmicos e variáveis. Parâmetros são informações numéricas que descrevem as características do espaço virtual (digital) que gera o projeto. Constituem campos de força, de gravidade, direções, densidades que participam dinamicamente da criação das formas [LYNN, 1998: 23-25].

Essas três propriedades se combinam para gerar possibilidades virtuais para projetar não sobre um suporte plano que configura um espaço cartesiano e estático, mas dentro do suporte que é um espaço animado. As splines são afetadas por esse contexto digital. Os pesos e direções que incidem nos vértices de controle podem ser afetados por campos de atração

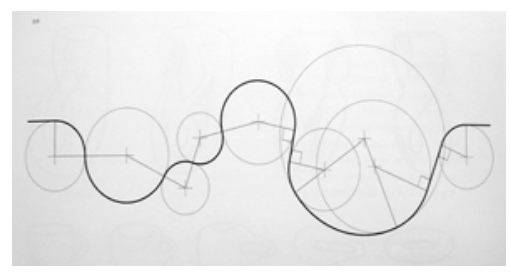

163. construção geométrica de uma linha

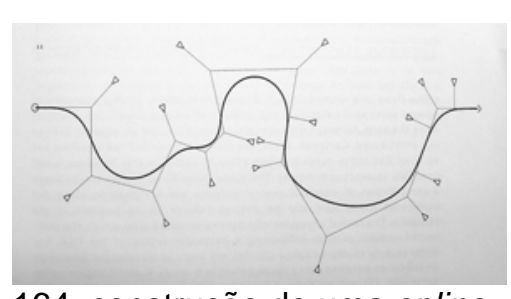

164. construção de uma spline 


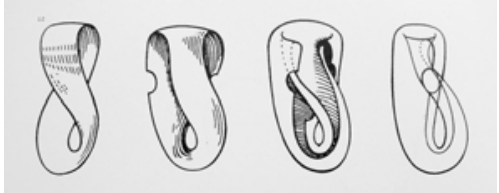

165. construção de uma superfície topológica: tira de Moebius.
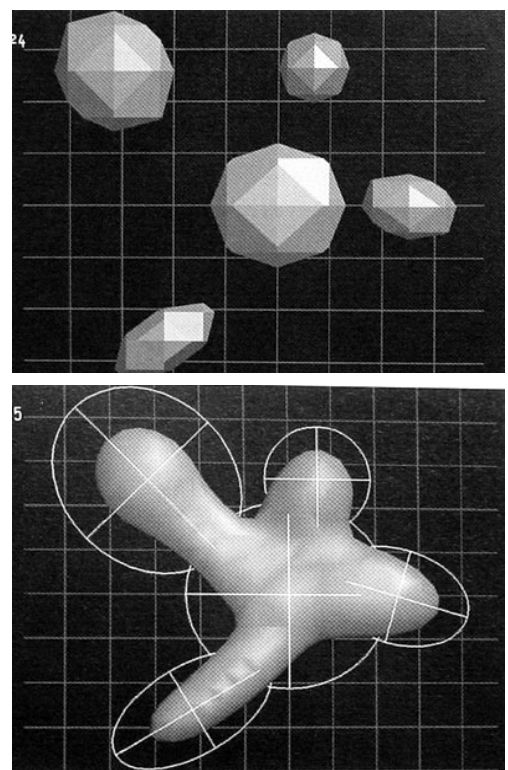

166. construção de um blob ou repulsão definidos por parâmetros. Do mesmo modo, os pesos de uma spline podem afetar outras splines, resultando em blobs, estruturas que se infletem mutuamente formando conjuntos compostos. Os blobs não são nem múltiplos nem singulares, mas uma fusão de múltiplos elementos num conjunto que se comporta como uma singularidade, permanecendo irredutível a qualquer um dos elementos singulares. Os blobs têm um centro, uma superfície, uma massa relativa a outros objetos e um campo de influência, uma zona relacional em que podem se fundir ou redefinir [LYNN, 1998: 30]. São as formas próprias da lógica matemática do suporte digital, material para a experimentação da arquitetura virtual em curso de atualização como linguagem. 
Como diz Quéau [1999: 91-99], o digital, graças à sua natureza numérica e simbólica, no sentido matemático do termo, torna possível todo o tipo de mediação entre linguagens formais e representações sensíveis. O digital é, em primeiro lugar, linguagem, encarnada em modelos matemáticos e programas informáticos, espaço apropriado para uma criação problematizante que coincide com a emergência do novo.

Segundo Novak [1991: 225-227] o ciberespaço inverte o modo de interação com a informação, passando de uma relação externa a uma relação em que se está entre, no fluxo da informação, dentro dela. Assim, colocar o homem dentro do espaço da informação é um problema da arquitetura. E o ciberespaço é arquitetura, tem arquitetura, contém arquitetura, sendo, portanto, o habitat da imaginação. É poesia inabitada e navegá-lo é como se tornar uma folha flutuando.

Para ele, a transição do espaço real para o ciberespaço será melhor compreendida examinando a expressão humana que combina ciência e arte, o profano e o espiritual, o contingente e o permanente: a arquitetura. Especialmente a arquitetura visionária, a arquitetura do excesso de possibilidades que procura escapar do confinamento limitador da realidade. Novak postula uma abordagem poética da virtualidade do digital. A poesia opera a inflexão da linguagem para gerar a inflexão do significado, como se fosse uma linguagem líquida. A natureza virtual do ciberespaço solicita também uma abordagem poética. Assim como a poesia está além da linguagem ordinária, a arquitetura visionária também excede a arquitetura convencional, procurando um extremo, além do imediato [NOVAK, 1991: 242-244]. 
"O ciberespaço é líquido. (...) A arquitetura líquida é mais do que cinética, robótica, uma arquitetura de partes fixas e conexões variáveis. A arquitetura líquida respira, pulsa, vibra como uma forma e pousa como outra. A forma da arquitetura líquida é contingente aos interesses do usuário; uma arquitetura que se abre para me receber e se fecha para me defender; é uma arquitetura sem portas e sem vestíbulos, onde o próximo recinto está sempre onde preciso que esteja e é sempre aquilo que preciso." [NOVAK, 1991: 250].

A arquitetura líquida no ciberespaço é uma arquitetura do virtual que não mais se satisfaz com espaço, forma e luz. Como os peixes e os barcos, é uma arquitetura de relações flutuantes [NOVAK, 1991: 251]. Os avanços científicos na concepção e compreensão do espaço devem ser considerados pelos arquitetos com um novo discurso algorítmico e computacional, ao mesmo tempo crítico e poético [NOVAK, 1995: 44]. Imersa na matéria fluxo de variação contínua, de modulações oscilantes da energia que se transforma em informação, liberta dos limites do plano bidimensional sem espessura, o pensamento da arquitetura encontra o meio ideal para a emergência de novas organizações espaciais e formais.

O digital, espaço de síntese [PLAZA 1991; 1998] operando a convergência de modelos científicos, de pensamentos filosóficos e de fazeres artísticos numa organização não-linear, relacional, sistêmica, permite que a gênese da arquitetura, entre diagramas e dobras, simulações e interações atinja graus de complexidade [JENCKS, 1997a] antes não alcançados e talvez nem mesmo almejados. A arquitetura do virtual engendra um novo espaço, ao mesmo tempo em que nele, digital, é concebida. No lugar da arquitetura como máquina de morar, a 
arquitetura se transforma em algoritmo para interagir [NOVAK 1998: 27].
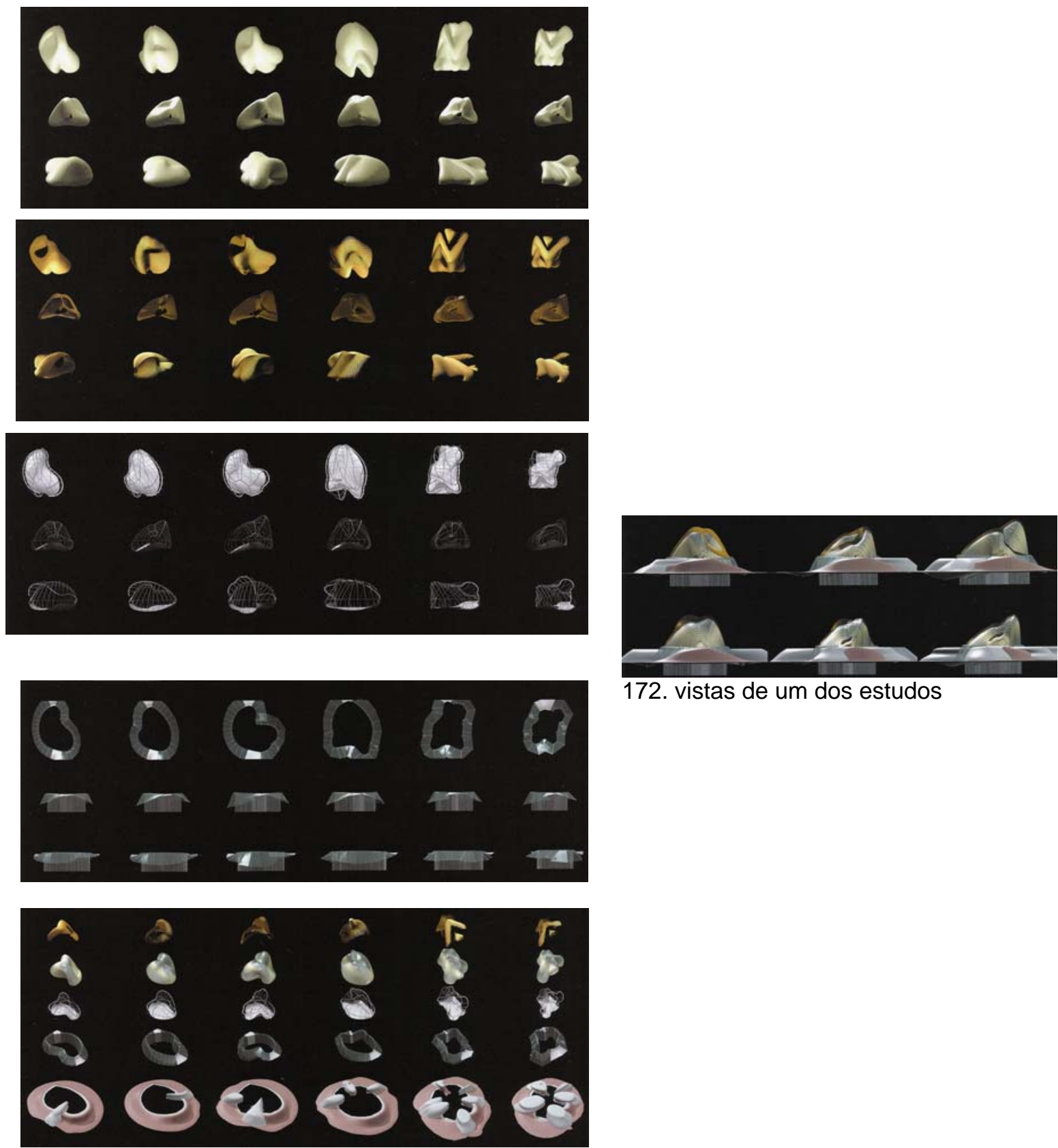

167 a 171. estudos para seis casas embriológicas: o finito variável dos elemetos 
Como ilustra o projeto das casas embriológicas de Greg Lynn (2000). Ele descreve o projeto como uma estratégia para invenção do espaço doméstico que contempla questões contemporâneas de identidade e variabilidade, personificação e continuidade, fabricação e montagem flexíveis. Ao utilizar um sistema geométrico paramétrico rigoroso, a geração da forma e do espaço encontra a liberdade da variação infinita, um finito variável. Todas as unidades diferem entre si embora guardando uma linguagem comum do desenho ao sistema espacial, o que permite o reconhecimento de uma marca encarnada na novidade do não igual. Ao contrário da arquitetura moderna, não há casa embriológica ideal. Todas correspondem idealmente ao pressuposto geral, ideais em suas mutações.

Cada casa embriológica foi projetada como uma superfície flexível. Têm dois pavimentos, o inferior que pode variar de $40 \mathrm{~m}^{2}$ a $65 \mathrm{~m}^{2}$ e o superior que varia de $20 \mathrm{~m}^{2}$ a $40 \mathrm{~m}^{2}$. As aberturas, os acessos, a orientação climática foram projetadas através de rasgos e curvilíneos, lanternas e poros derivados da topologia das próprias superfícies. O envelope de fechamento também está conectado ao solo, assim as mudanças na forma da superfície implicam em adaptações da paisagem, afetando o contexto de sua implantação.

173. estudos: seis casas

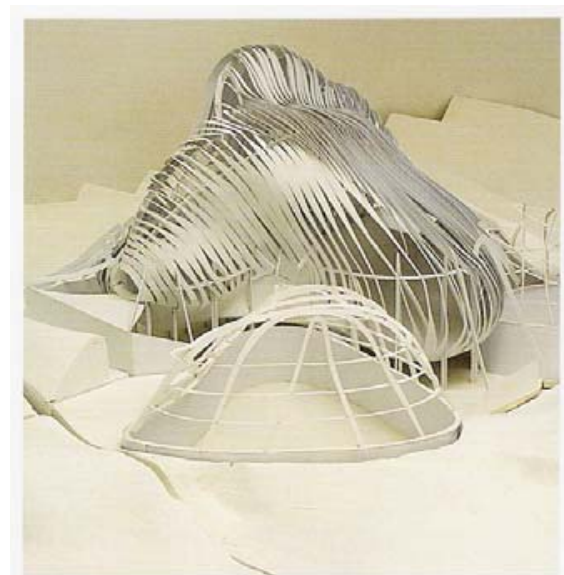

174. maquete

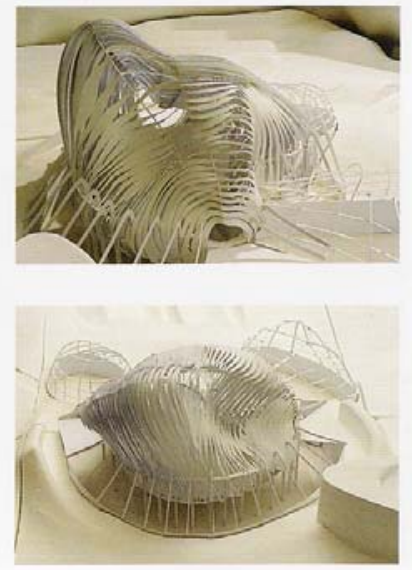


No projeto Data-driven (1998), de Marcos Novak, uma série de informações (data) foram extraídas de duas páginas da web, linkadas e interpretadas como dois conjuntos de pontos no espaço tridimensional, onde, usando interpolação de curvas spline, duas curvas foram construídas e, a partir delas, duas superfícies paramétricas interpoladas. Considerando uma superfície como partida e a outra como destino são feitas várias ligações entre elas. Cada linha foi modulada segundo o conteúdo da informação geradora, criando nodos de informação conectando as duas superfícies. Tanto o algoritmo como as informações se relacionam em tempo real, provocando transformações e variações na forma.

As possíveis formas data-driven se alteram a cada transição entre os nodos de informação no ciberespaço; entre cada nodo se formam hyperlinks que geram espaços derivados do cruzamento de informações. Esses outputs (resultados) podem assumir materialidade arquitetônica conectada em tempo real ao ciberespaço, construindo um espaço multidimensional, relacional e sistêmico.

Novak pretende alcançar proposições arquitetônicas, como ele chama, que sejam líquidas, algorítmicas, transmissíveis e derivadas de geometrias complexas. Líquida significa a resolução da forma baseada em informação. Algorítmica quer dizer que a forma é resultante de princípios paramétricos baseados em sistemas dinâmicos de manipulação da informação. Transmissível subentende que a descrição matemática da proposição é explícita e permite transmitir a arquitetura para a construção ou para o ciberespaço. Derivada de geometrias complexas significa empregar quatro ou mais dimensões do espaço, manipular sua constituição curvilínea e incluir 


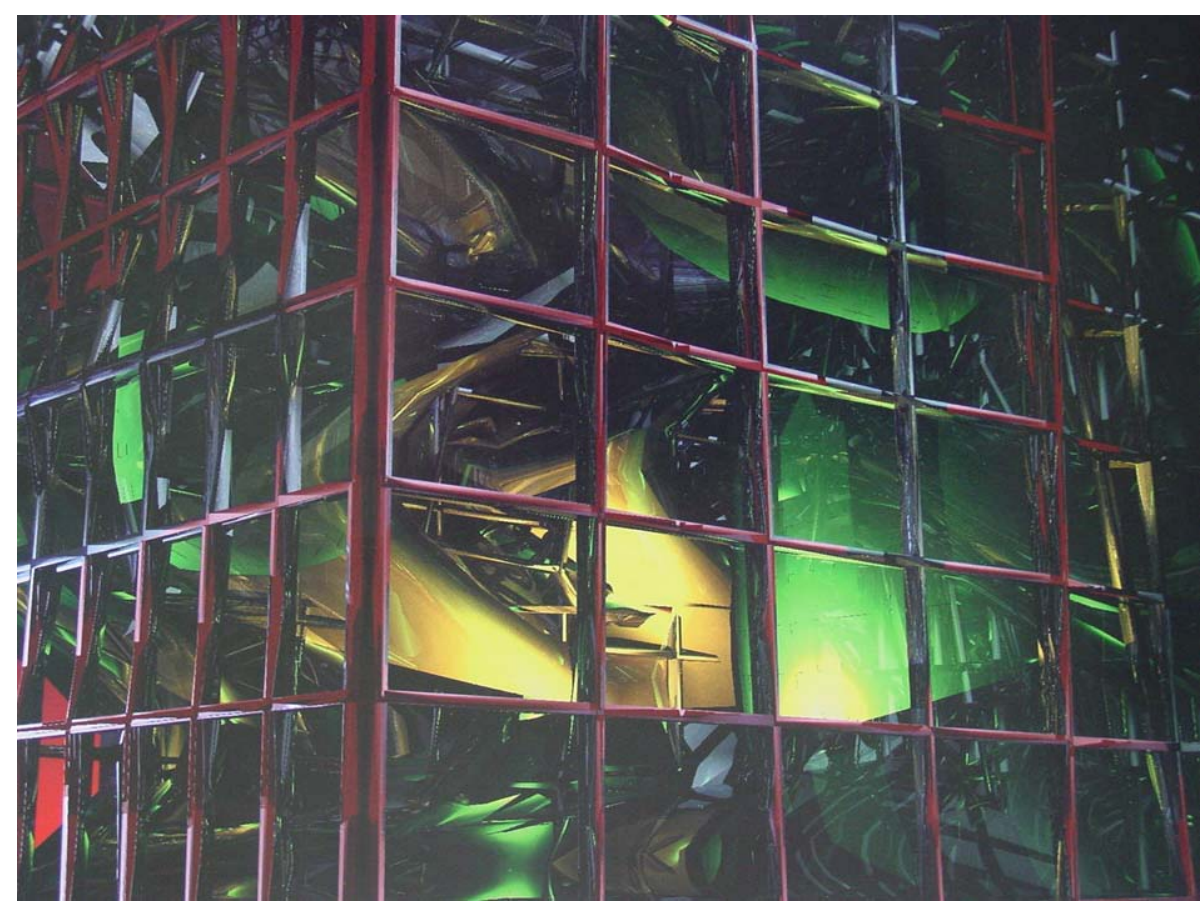

179. Paracube: vista geral

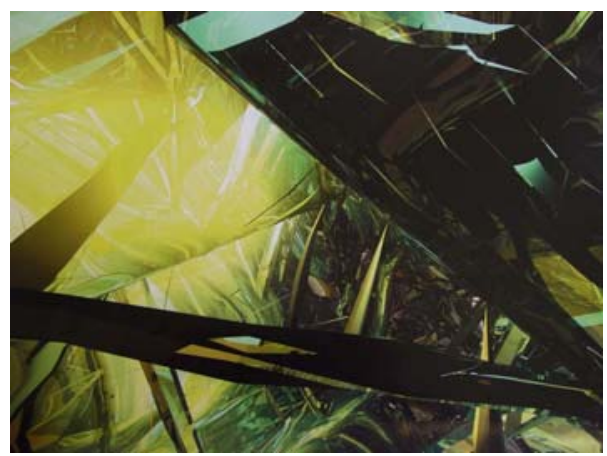

180. detalhe interior
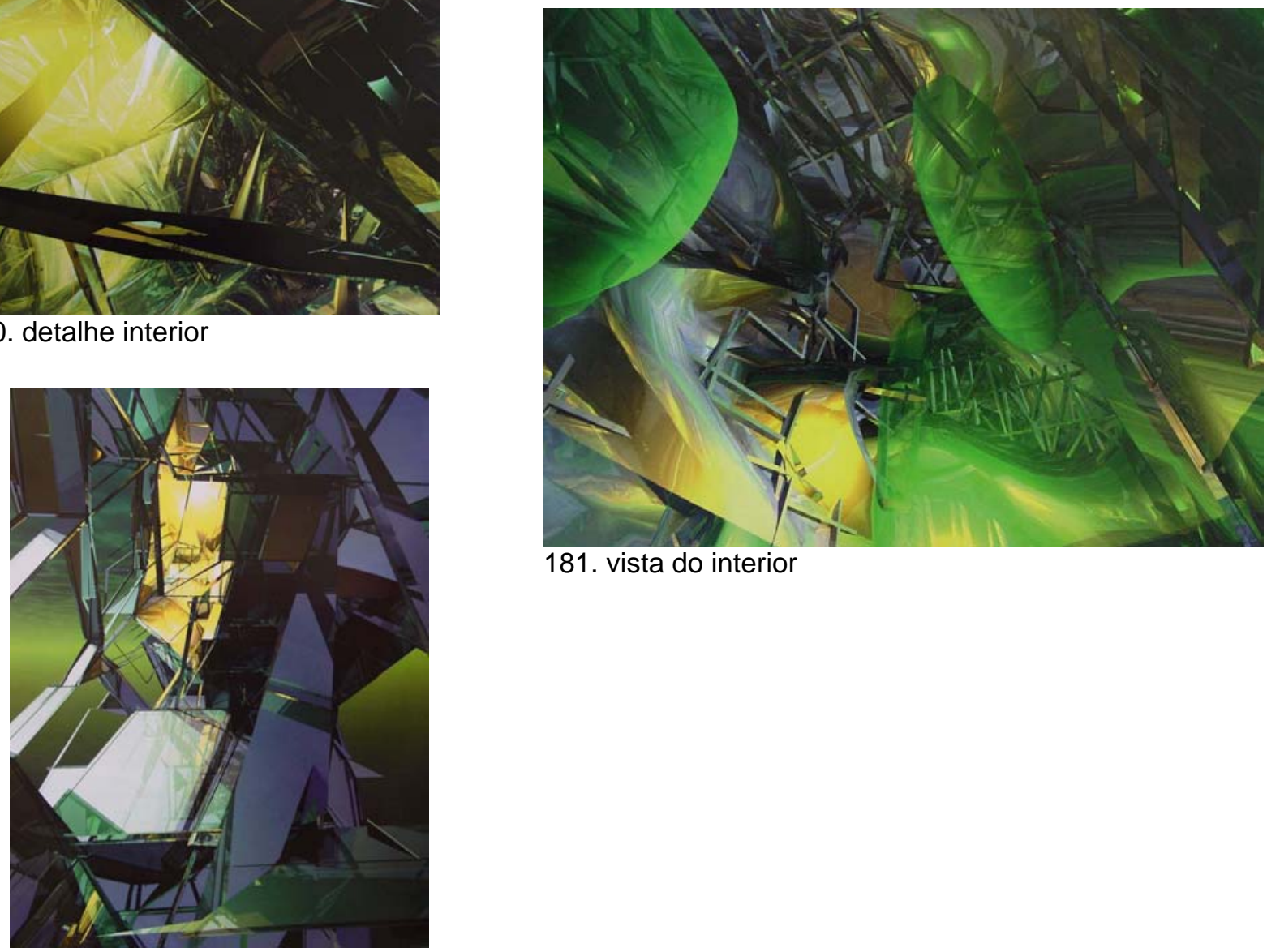

181. vista do interior

182. detalhe 
o tempo como dimensão do espaço formando um espaçotempo contínuo.

O Paracube (1998) é composto por seis superfícies, cada uma contendo um sistema de coordenadas vetoriais próprio. As variações de cada superfície, definidas por parâmetros algorítmicos, contaminam as superfícies adjacentes, criando um cubo topológico. A estrutura forma um cubóide apesar das variações em suas faces. As funções matemáticas são manipuladas para criar dois elementos: uma pele de fechamento e um esqueleto estrutural. Essa manipulação geradora é incrementada por perturbações iterativas, resultando

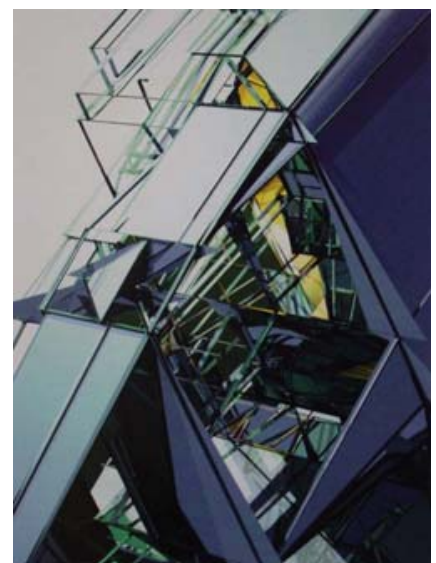

183. Paracube: detalhe

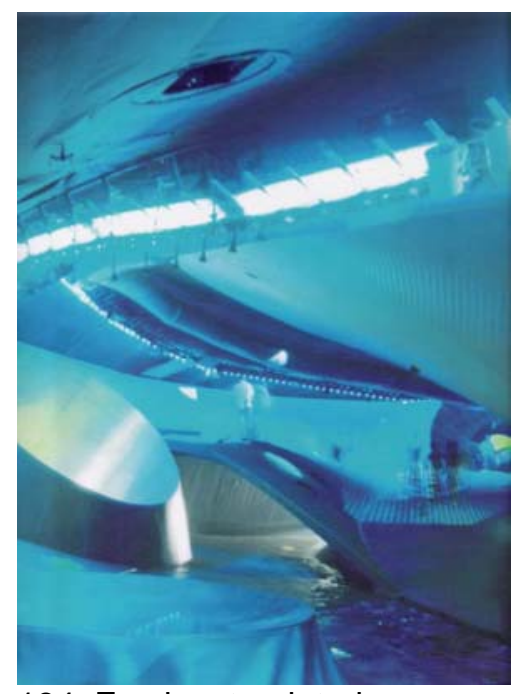

184. Freshwater: interior integridade formal das elipses. Esse partido é traduzido em um sistema vetorial e assim é o movimento das forças que lhe dá coerência. O pavilhão parte do conceito de líquido aplicado à forma, aos materiais e ao ambiente interno que procura fundir hardware (equipamentos), software (programas) e wetware (tecnologias da água). O espaço é uma instalação interativa, conectada a rede de informação, construindo um espaço de direções e posições indistintas. O chão é uma superfície de informação e está em todo os lugares, é hiperdimensional. Nenhuma superfície é 


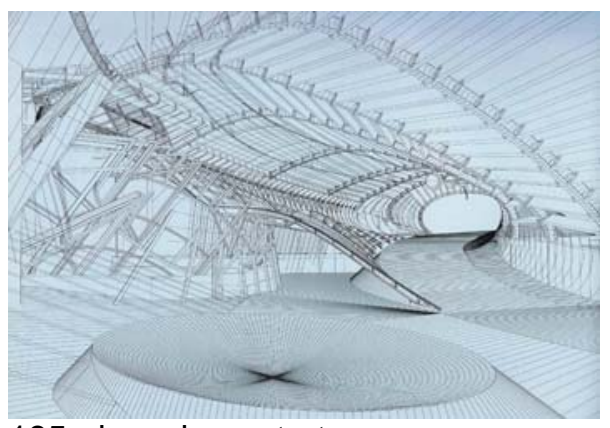

185. desenho: estrutura e poço

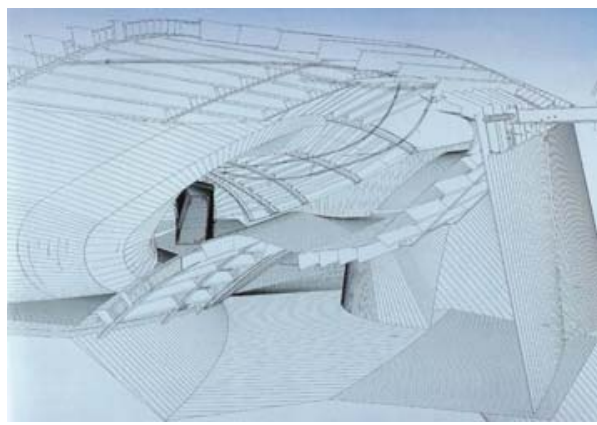

186. desenho: espaço interno

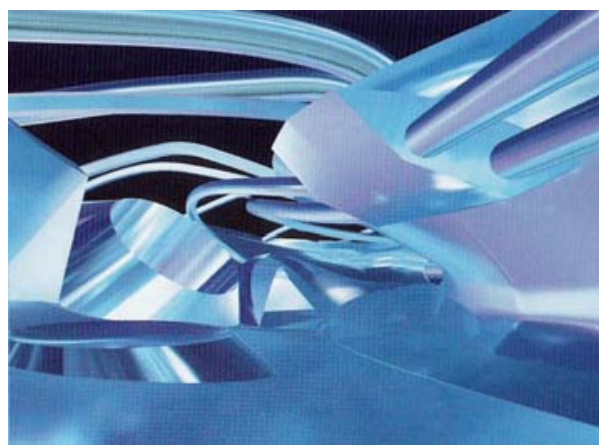

189. modelo digital, interior: poço

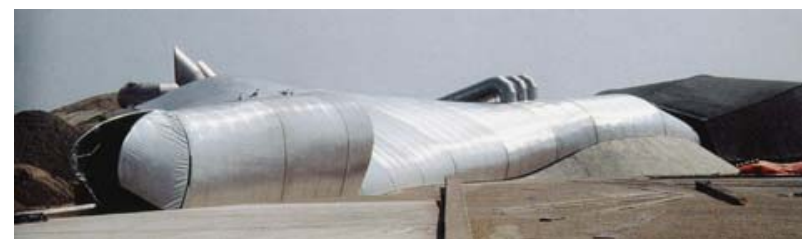

187. vista externa: acesso

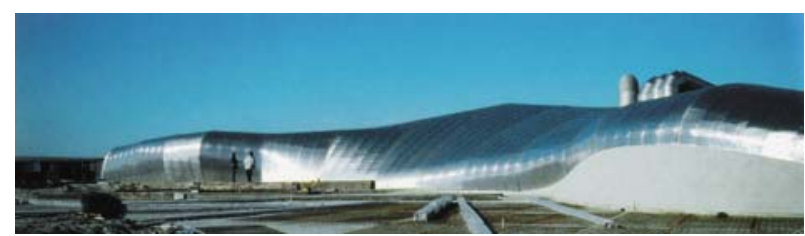

188. vista externa

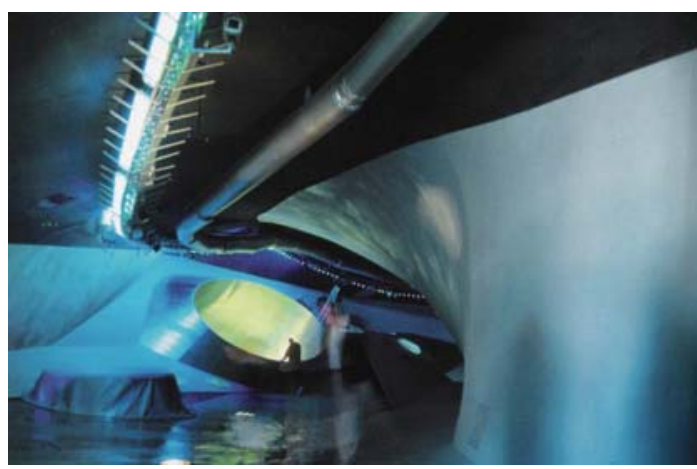

190. interior

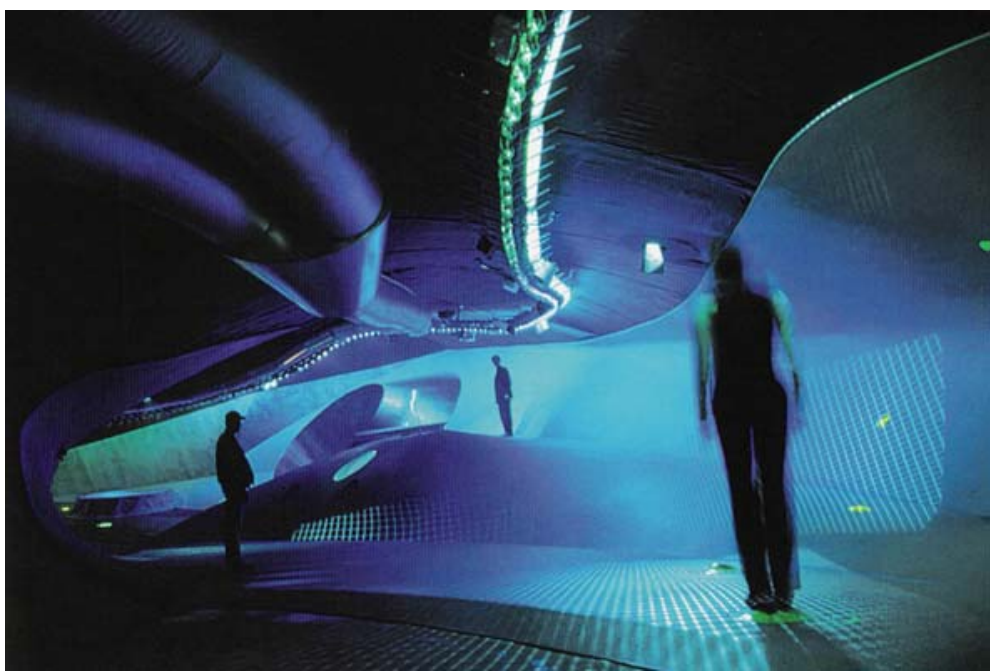

191. interior 
plana, criando uma instabilidade, um espaço topológico em que o corpo se transforma em vetor e percebe topologicamente, uma vez que piso e teto resultam das deformações da forma. Os materiais são aquosos, borracha, tecidos, gelo, vapor, a própria água, meios eletrônicos, sons, luzes, projeções e sensores que ativam esses dispositivos. Não há diferença entre material e imaterial, entre virtual e real. As aberturas para o exterior, que poderiam apontar para uma perspectiva, um horizonte, são substituídas por um poço, vertical, em direção à vertigem do espaço em constante transformação.

Na Casa Virtual (1987-1997) de Eisenman, o diagrama dos nove quadrados ressurge como diagrama dos nove cubos. Das casas iniciais que instauram o pensamento diagramático que aponta para a tecnologia numérica e digital, para uma linguagem da informação, resulta como desdobramento a casa virtual. As cada uma das suas casas tinha um número, esta poderia ser a casa do número infinito, talvez o experimento mais radical de Eisenman.

Os nove cubos formam uma malha tridimensional relacional e dinâmica, um campo vetorial. Cada linha dessa malha é um vetor, uma força em movimento que, na interação com as outras, redefine infinitas variações para o conjunto. A aplicação de um algoritmo condiciona a recorrência das transformações, do movimento iterativo e o número de cubos conectados. Dois cubos são isolados dos outros nove e sobre eles o programa realiza uma leitura, repetida por duas vezes. Quando não há diferenças perceptíveis, o sistema para. As variações produzem traços que constituem diagramas de linhas que formam superfícies que, por sua vez, definem os limites do espaço. [GALOFARO, 1999] A casa virtual se define como espaço de simulação da interioridade a ser descoberta e 
experimentada, espaço virtual, com as qualidades inerentes ao suporte interativo digital.

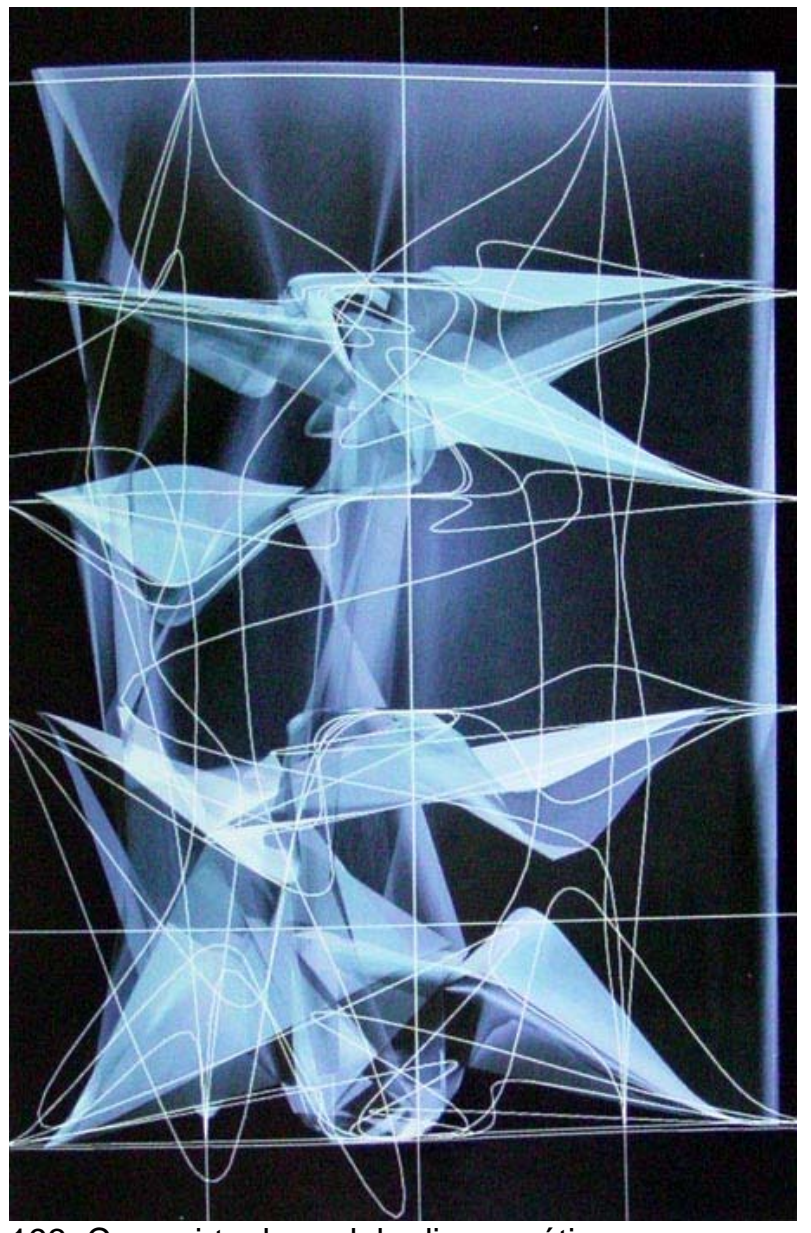

193. Casa virtual: modelo diagramático

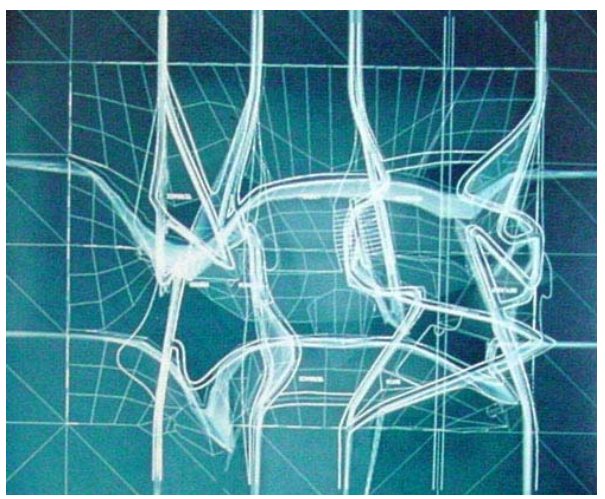

196. primeiro pavimento
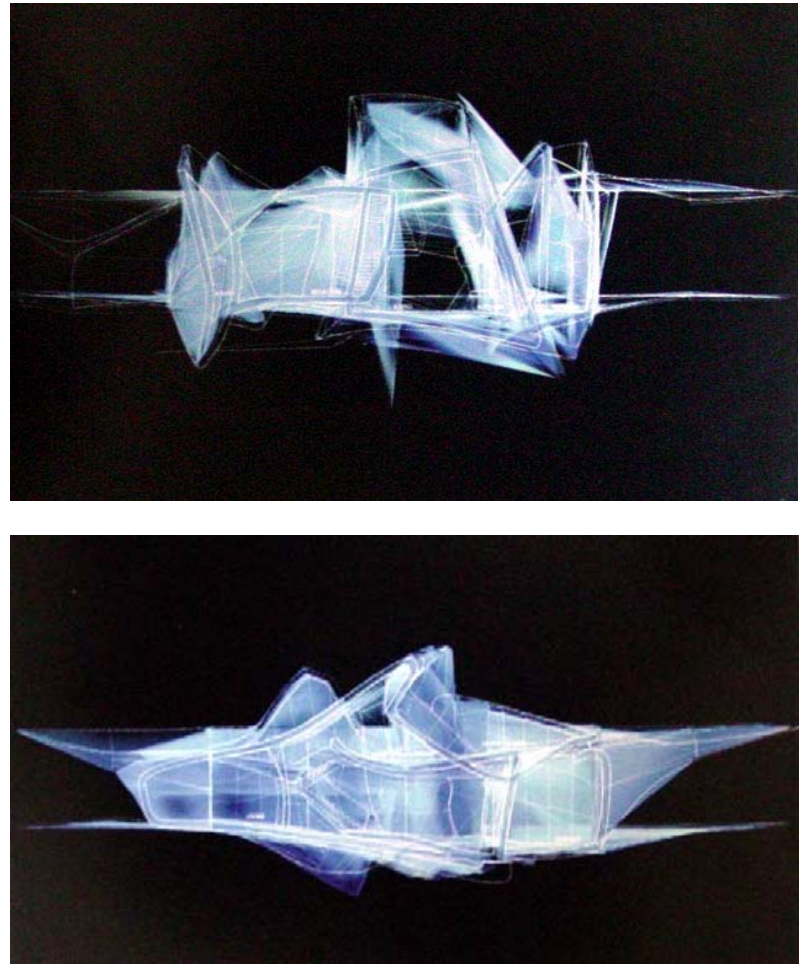

194 e 195. cortes

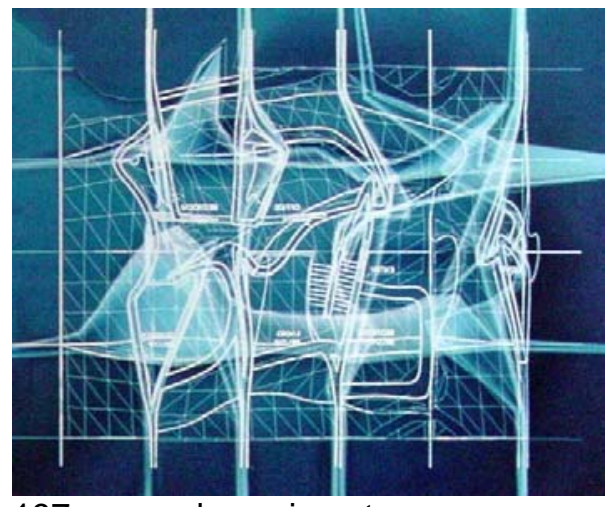

197. segundo pavimento 
210 
conclusão

\section{a arquitetura oscilando entre 0s e 1s}


212 
O objetivo desta investigação não era outro senão procurar explicações para o papel dos meios digitais na produção da arquitetura contemporânea, pensamento e gênese. Nessa busca procurou encontrar antecedentes que permitissem abordar o digital como parte do processo de evolução da arquitetura. E ainda buscou estudar em que medida a natureza virtual desse suporte que constitui um espaço de interações e simulações, atua no processo de crescente complexidade da arquitetura no panorama da cultura e dos processos criativos. O percurso da pesquisa procura demonstrar como o processo evolutivo do pensamento arquitetônico traduzido em teoria, experimentação e obras construídas atinge mais uma etapa de sua evolução contínua, através da tecnologia digital de processamento de informação.

Com a evolução das ferramentas de representação da arquitetura, com a transformação do suporte em espaço dinâmico e interativo das simulações, a própria noção da arquitetura se renova, colocando em questão a posição do arquiteto. Agora, ele se confronta com máquinas como sistemas significantes que funcionam como instrumentos de mediação que devem ter seu potencial criativo explorado. Compreender que o suporte digital tem antecedentes nas tecnologias numéricas desde as técnicas do Renascimento, pode auxiliar os arquitetos a encontrar, não só, novas possibilidades projetivas nos enredamentos maquínicos, mas sobretudo, a produzir outras condições de leitura da inserção cognitiva da arquitetura contemporânea .

Assim, procurou-se tecer os conceitos que permitissem realizar a leitura dos procedimentos que delineiam a arquitetura maquínica. Desse modo, analisou-se como a arquitetura enfrentou e superou sua dimensão funcional ou de impacto visual para enfrentar a elaboração diagramática do pensamento 
em sua própria dinâmica, ou seja, da visão estática da perspectiva aos desdobramentos das simulações interativas, ou ainda, do paradigma mecânico ao maquínico, uma vez que não se trata da técnica do saber fazer, mas da tecnologia do saber pensar. Passagem do mecânico baseado na função, na estrutura e na ordem, para o maquínico regido por relações entre sistemas e organizações.

Em consonância com as transformações da cultura que levam a uma nova racionalidade, a arquitetura se constitui como um todo difícil construído sobre complexidades e contradições de seus próprios modos de pensar e fazer, teoria e projeto. O diagrama da arquitetura maquínica se faz no movimento dinâmico dos desdobramentos analógico-digitais Seus procedimentos se baseiam em conceitos que assumem, no fluxo da evolução, configurações diferentes a cada momento, mas reconhecíveis como continuidade. Nesse fluxo opera-se com a capacidade relacional do processo da cognição por analogia; com o pensamento diagramático, indutivo e experimental que torna visíveis aos olhos da mente as hipóteses projetivas em desenvolvimento; com o processo dialógico do fazer que transita entre material e procedimento e, finalmente, com a base sintática que qualifica a obra, expondo sua própria consecução projetiva e experimental. Embora nem sempre explícitos teórica e praticamente, esses procedimentos estiveram sempre relacionados à arquitetura, da geometria à tecnologia da informação.

É assim que no cerne do Moderno surgem exemplos de arquiteturas realizadas segundo diagramas relacionais. É o caso do Modulor como tecnologia analógico-digital, numerização do corpo para propor uma arquitetura como um organismo baseado em sistemas de relação. Esse mesmo princípio pode ser aplicado em outras obras onde a analogia se 
faz com sistemas dinâmicos baseados em relações orgânicas, como na obra estudada de Wright. É desse modo que o par material / procedimento passa pela experimentação com os processos de Gaudi para alcançar a forma, ou da transformação da matéria informe como concreto em estrutura, desembocando na relação análise / síntese. O desenvolvimento dessa experiência numeriza a função, transformando o programa da arquitetura em informação numérica, como nas proposições de síntese da forma de Alexander, que são levadas às últimas conseqüências nas gramáticas da forma de Mitchell, Stiny e Knight, baseadas em sintaxes computacionais.

Se o digital já estava sendo processado como pensamento e procedimento, quando se desenvolvia uma arquitetura que passava do paradigma mecânico para o maquínico, o que permanece na passagem do Moderno para a modernidade é o próprio Moderno como ruído, como descontinuidade:

"A modernidade escapa dos domínios conceituais para encontrar o cotidiano fragmentado e complexo que é decorrência das conquistas tecnológicas comandadas pela razão. (. . . ) A modernidade sugere uma outra postura epistemológica na qual o homem e sua razão enfrentam e aderem a um mundo em transformação constante mas indeterminada, porque depende da mútua interação homem / natureza e das possíveis, diversas, mas não necessárias respostas provocadas por essa interação. No ápice da modernidade, as relações sociais e culturais se mundializam; o homem conhece mais, está seguro da sua real capacidade de conhecer, mas está cada vez mais incerto." [FERRARA, 2000: 173]

E é por esse caminho que se chega a arquitetura de Peter Eisenman e Frank Gehry. A arquitetura de Eisenman se faz sobre o pensamento diagramático que antecipa a utilização 
dos computadores e encontra no digital o espaço ideal para sua gênese, assim como a postura experimental em relação aos materiais de Gehry se mantém quando ele enfrenta o suporte digital, possibilitando-Ihe alcançar complexidades não pressentidas. Como vimos, a interpretação dessas complexidades revela, de fato, uma arquitetura que se lança pelos espaços das virtualidades. É no confronto com o computador que sua arquitetura supera os materiais e pode mirar o paradigma maquínico como seu referencial e revelar que pensamento e gênese da arquitetura podem ser deslocados para um tempo e um espaço simultâneos em que todos os saberes convergem sobre a base sintática das tecnologias numéricas. Espaço e tempo das simulações e das interações entre analogias, experimentações e diagramas digitais.

Se o percurso do trabalho pareceu muitas vezes sem destino, talvez seja porque o objeto que se enfrentou é de natureza instável e turbulenta e representa as incertezas da modernidade. Nos fluxos oscilantes da matéria líquida do digital, o que se procurou foi dotar a experiência de um sentido mais profundo do que o usual. E nas tessituras dessa rede, não teria sido possível imaginar que se chegaria a esse lugar, trilhando os caminhos que foram traçados. Ao se chegar ao final da aventura de enfrentar um objeto que problematiza os cânones da disciplina, mesclam-se certo sentido de frustração e um sentimento de impotência para mensurar o que foi realizado. Não poderia haver nada mais apropriado do que a dúvida de Argan:

"Neste ponto só se pode colocar em discussão o sentido da vivência humana no mundo: é preciso saber se tudo aquilo que houve foi projeto ou destino, se o homem construiu sobre os próprios desígnios ou se, pensando fazê-lo, fez algo que já estava dito e decidido." [ARGAN, 2001: 12] 


\section{REFERÊNCIAS BIBLIOGRÁFICAS}


218 


\section{REFERÊNCIAS BIBLIOGRÁFICAS}

ALBERTI, Leon Battista. Da pintura, tradução Antonio Silveira Mendonça. Campinas: UNICAMP, 1992.

ALEXANDER, Christopher. Ensayo sobre la síntesis de la forma, tradução Enrique Revol. Buenos Aires: Ediciones Infinito, 1969.

Três aspectos de matemática y diseño, tradução

Beatriz de Moura. Barcelona: Tusquets Ediciones, 1971.

Sistemas que são sistemas de sistemas que são... tradução Marlene Picarelli, do original da Revista Casabella 321, ano XXXI, 1967. Folheto datilografado, São Paulo: Faculdade de Arquitetura e Urbanismo da Universidade de São Paulo, 1972.

ALLIEZ, Éric. Deleuze filosofia virtual, tradução Heloisa Rocha. Rio de Janeiro: Editora 34, 1996.

ALLIEZ, Éric (org.). Gilles Deleuze, uma vida filosófica, tradução Ana Lucia de Oliveira (coord.). São Paulo: Editora 34, 2000.

ALSINA, Claudi e GÓMEZ-SERRANO, Josep. Geometria Gaudiana, in Gaudí: a procura da forma, pp. 72-95. São Paulo: Instituto Tomie Othake, 2004.

ANDRADE, Mario de. Do desenho, in Aspectos das artes plásticas no Brasil, Obras completas de Mario de Andrade, volume XII, pp. 69-77. São Paulo: Livraria Martins Editora, 1965.

ARANTES, Otília. O lugar da arquitetura depois dos modernos. São Paulo: EDUSP, 1993.

ARGAN, Giulio Carlo. História da arte como história da cidade, tradução Píer Luigi Cabra. São Paulo: Martins Fontes, 1992.

Ática, 2001. Projeto e destino, tradução Marcos Bagno. São Paulo:

Carotti. São Paulo: Cia das Letras, 2002.

ASCOTT, Roy. The architecture of cyberperception, in Architectural Design, Architects in cyberspace, volume 65, $n^{\circ}$ 11/12, pp. 38-41. Londres: Academy Editions, 1995.

BASTIDE, Roger (Coord.). Usos e sentidos do termo estrutura - nas ciências humanas e sociais, tradução Maria Heloísa Capellato. São Paulo: Editora Herder/EDUSP, 1971.

BELLOUR, Raymond. A dupla hélice, tradução Elizabeth Lissovsky, in PARENTE, André, Imagem-Máquina, pp. 214-230. Rio de Janeiro: Editora 34, 1993.

BENEDIKT, Michael (ed.). Cyberspace: first steps. Cambridge: MITPress, 1991.

BENEVOLO, Leonardo. O último capítulo da arquitetura moderna. Lisboa: Edições 70, 1985.

BENJAMIN, Walter. A obra de arte na era de sua reprodutibilidade técnica, in Magia e técnica, arte e política: ensaios sobre literatura e história da cultura, tradução Sergio Paulo Rouanet, pp. 165-196. São Paulo: Brasiliense, 1985. 
BENSE, Max. Pequena estética, tradução Haroldo de Campos. São Paulo: Perspectiva, 1975.

BENVENISTE, Emile. Estrutura em lingüística, in BASTIDE, Roger, Usos e sentidos do termo estrutura - nas ciências humanas e sociais, tradução Maria Heloísa Capellato, pp.23-31. São Paulo: Editora Herder/EDUSP, 1971.

BLAKE, Peter. Corbusier - Architecture and form. Nova lorque: George Braziller, 1963.

BLETTER, Rosemary H. Frank Gehry's spatial reconstructions, in The architecture of Frank Gehry, Walker Art Center, pp. 25-47. Minneapolis, Nova Iorque: Rizzoli, 1986.

BOESIGER, Willy. Le Corbusier, tradução Julio Fischer. São Paulo: Martins Fontes, 1998.

BUXADÉ, Carles e MARGARIT, Joan. Estrutura e espaço, in Gaudí: procura da forma, pp. 96-114. São Paulo: Instituto Tomie Othake, 2004.

CALABRESE, Omar. A idade neobarroca, tradução Carmem de Carvalho e Artur Mourão. Lisboa: Edições 70, 1987.

CASTELLS, Manuel. The informational city: information technology, economic restructuring and the urban-regional process. Oxford: Blackwell Publishers, 1989.

CHAUÍ, Marilena. Janela da alma, espelho do mundo, in NOVAES, Adauto (Org.), O olhar, pp. 31-63. São Paulo: Cia das Letras, 1988. Convite à Filosofia. São Paulo: Ática, 2002.

CHKLOVSKI, Victor. Sur la théorie de la prose. Lausanne: Editions L'Age d'Homme, 1973a.

El arte como procedimiento, in Formalismo y Vanguardia - textos de los formalistas rusos, vol. 1, Comunicación série $B$, pp. 85-113. Madrid: Alberto Corazon, 1973b.

CHOAY, Françoise. Le Corbusier. Nova lorque: George Braziller, 1960. Perspectiva, 1992. O urbanismo, tradução Dafne Rodrigues. São Paulo:

CHOMSKY, Noam. Syntactic structures. Haia, Paris: Mouton, 1957.

COLLINS, Peter. Los ideales de la arquitectura moderna: su evolución (1750-1950). Barcelona: Gustavo Gili, 1970.

COUCHOT, Edmond. A tecnologia na arte: da fotografia à realidade virtual, tradução Sandra Rey. Porto Alegre: UFRGS, 2003.

COULQUHOUN, Alan. Modernidade e tradição clássica: ensaios sobre arquitetura, tradução Christiane Brito. São Paulo: Cosac\&Naify, 2004.

DAMISH, Hubert. The origin of perspective, tradução John Goodman. Cambridge: MITPress, 1995.

DAVIDSON, Peter e BATES, Donald. Architecture after geometry (editorial), in Architectural Design, Architecture after geometry, volume 67, $n^{\circ} 5 / 6$, pp. 711. Londres: Academy Editions, 1997. 
DE FUSCO, Renato. Storia dell'architettura contemporânea. Roma, Laterza, 1985.

DELEUZE, Gilles. A imagem-tempo, cinema 2, tradução Eloísa Ribeiro. São Paulo: Brasiliense, 1990.

A Dobra: Leibniz e o Barroco, tradução Luiz Orlandi.

Campinas: Papirus, 1991.

Editora 34, 1992. Conversações, tradução Peter Pál Pelbart. Rio de Janeiro:

O atual e o virtual, in ALLIEZ, Éric, Deleuze filosofia virtual, tradução Heloísa Rocha, pp. 47-57. São Paulo: Editora 34, 1996.

1998.

Foucault, tradução José Carlos Rodrigues. Lisboa: Vega,

Bergsonismo, tradução Luiz Orlandi. São Paulo: Editora

34, 1999.

DELEUZE, Gilles e GUATTARI, Felix. O que é a Filosofia?, tradução Bento

Prado Jr. e Alberto Alonso Muñoz. Rio de Janeiro: Editora 34, 1992.

Mil Platôs: capitalismo e

esquizofrenia, Vol. 2, tradução Ana Lucia de Oliveira e Lucia Claudia Leão.

Rio de Janeiro: Editora 34, 1995.

Mil Platôs: capitalismo e

esquizofrenia, Vol. 4, tradução Suely Rolnik. São Paulo: Editora 34, 1997a. Mil Platôs: capitalismo e

esquizofrenia, Vol. 5, tradução Peter Pál Pelbart e Janice Caiafa. São Paulo: Editora 34, 1997b.

DOLLENS, Dennis. De lo digital a lo analógico. Barcelona: Gustavo Gili, 2002.

DUARTE, Fabio. Arquitetura e tecnologias da informação: da revolução industrial à revolução digital. São Paulo: UNICAMP/Annablume, 1999.

DUPUY, Jean Pierre. Nas origens das ciências cognitivas, tradução Roberto Leal Ferreira. São Paulo: UNESP, 1995.

EIKHENBAUM, Boris. La teoria del "método formal", in Formalismo y Vanguardia - textos de los formalistas rusos, vol. 1, Comunicación série B, pp. 27-83. Madrid: Alberto Corazon, 1973.

EISENMAN, Peter. Dall'ogetto allá relazionalità: la casa Del Fascio di Terragni, in Casabela, no 344, pp. 38-41. Milão: Casabela, 1970.

Real and Engish: The destruction of the Box. I., in Oppositions $n^{\circ} 4$, pp. 5-34. Nova lorque: The Institute for the Architecture and Urban Studies, 1974.

Post-Functionalism., in Oppositions $\mathrm{n}^{\circ} 6$, pp. sem numeração. Nova Iorque: The Institute for the Architecture and Urban Studies, 1976.

Aspects of modernism: Maison Dom-ino and the selfreferential sign. in Oppositions $n^{\circ} 15 / 16$, pp. 119-128. Nova lorque:The Institute for the Architecture and Urban Studies, 1979.

House $X$. Nova Iorque, Rizzoli, 1982.

Blue Line Text, in PAPADAKIS, A., Cooke, C. and

Benjamin, A. (Eds.), Deconstruction - Omnibus Volume, pp. 150-151. Nova Iorque: Rizzoli, 1989a. 
En Terror Firma: in Trails of Grotextes, in PAPADAKIS,

A., Cooke, C. and Benjamin, A. (Eds.), in Deconstruction - Omnibus Volume, pp. 152-153. Nova lorque: Rizzoli, 1989b.

Visões que se desdobram:a arquitetura na época da

mídia eletrônica, tradução Silvana Rubino, in Óculum n³, pp. 14-17.

Campinas: CAD/FAU PUCC, 1993.

Procesos de lo intersticial: notas sobre la ldea de lo

Maquinico de Zaera-Polo, in El Croquis n 83, pp.21-35. Madrid: El Croquis Editorial, 1997.

Iorque: Universe, 1999.

Diagram Diaries; introdução de Robert E. Somol. Nova

EISENMAN, Peter et al. Five Architects; introdução de Collin Rowe. Nova Iorque: Oxford University Press, 1972.

EPSTEIN, Isaac (Org.). Cibernética e Comunicação. São Paulo: Cultrix, 1973.

EVES, Howard e NEWSOM, Carroll. An introduction to the foudations and fundamental concepts of mathematics. Nova lorque: Rinehart \& Company, Inc., 1958.

FERRARA, Lucrécia D'Aléssio. A estratégia dos signos. São Paulo:

Perspectiva, 1981. Olhar periférico: informação, linguagem, percepção ambiental. São Paulo: EDUSP, 1993. Imagem virtual, espaço global e tempo contínuo, in Sinopses 30, pp. 7-12. São Paulo: FAU USP, 1998.

EDUSP, 2000. Os significados urbanos. São Paulo:

2002. Design em espaços. São Paulo: Rosari,

FOSTER, Hal. Design and crime (and other diatribes). Londres: Verso, 2002.

FOUCAULT, Michel. Vigiar e punir, tradução Raquel Ramalhete. Petrópolis: Vozes, 1987.

As palavras e as coisas: uma arqueologia das ciências humanas, tradução Salma Muchail. São Paulo: Martins Fontes, 2002.

FRAMPTON, Kenneth. Frontality vs. Rotation, in EISENMAN, Peter et al, Five Architects. Nova lorque: Oxford University Press, 1972.

Martins Fontes, 1997. História crítica da arquitetura moderna. São Paulo:

FRIEDMAN, Mildred. Fast Food, in The architecture of Frank Gehry, Walker Art Center, pp. 87-108. Minneapolis, Nova lorque: Rizzoli, 1986.

Universe, 1999. Gehry talks: architecture + process. Nova Iorque:

GALOFARO, Luca. Digital Eisenman: An Office of the Electronic Era. Basiléia, Birkhauser, 1999.

GANDELSONAS, Mario. From structure to subject: the formation of an architectural language, in House X, pp. 7-31. Nova lorque: Rizzoli, 1982.

GEHRY, Frank. Comentaries, in FRIEDMAN, Mildred Gehry talks: architecture + process, pp. 40-55. Nova Iorque: Universe, 1999. 
GENET, Jean. O ateliê de Giacometti, tradução Célia Euvaldo. São Paulo: Cosac \& Naify, 2000.

GIBSON, William. Neuromancer. Nova lorque: Ace Books, 1984.

GOMBRICH, Ernest H. A História da arte, tradução Álvaro Cabral. Rio de Janeiro: Zahar Editores, 1979.

GÓMEZ-SERRANO, Josep. Arcos em catenária, in Gaudí: a procura da forma, pp. 158-167. São Paulo: Instituto Tomie Othake, 2004.

GUATTARI, Felix. Caosmose: um novo paradigma estético, tradução Ana Lucia de Oliveira e Lucia Claudia Leão. Rio de Janeiro: Editora 34, 1992.

Da produção de subjetividade, tradução Suely Rolnik, in PARENTE, André (Org.), Imagem-Máquina, pp.177-191. Rio de Janeiro: Editora 34, 1993.

GUERRA, Abílio. Disciplina: ordem e ofício (editorial), in Óculum nº 3, p. 3. Campinas: CAD/FAU PUCC, 1993.

HARAWAY, Donna J. Manifesto ciborgue: ciência, tecnologia e feminismosocialista no final do século XX, in SILVA, Tomaz T. (org.), , Antropologia do ciborgue: as vertigens do pós-humano, pp. 37-129. Belo Horizonte:

Autêntica, 2000.

HARVEY, David. A condição pós-moderna, tradução Adail Sobral e Maria Stela Gonçalves. São Paulo: Loyola, 1993.

HEIMS, Michael. The erotic ontology of cyberspace, in BENEDIKT, Michael (ed.), Cyberspace, first steps, pp. 59-80. Cambridge: MITPress, 1991.

HEJDUK, John. Three projects, 1962-66, in Architectural Design Vol. 54, $\mathrm{n}^{\circ}$ 11/12. Londres, Academy Editions, 1984.

1985.

The mask of Medusa, works 1947-1983. New York: Rizzoli,

HINES, Thomas. Heavy Metal: the education of F.O.G., in The architecture of Frank Gehry, Walker Art Center, pp. 11-21. Minneapolis, Nova lorque: Rizzoli, 1986.

ITO, Toyo. Sendai Mediatheque. Barcelona: Actar, 2003.

JAKOBSON, Roman. La Dominante, in Huit questions de poétique, pp. 7785. Paris: Editions du Seuil, 1977.

Lingüística e comunicação, tradução Izidoro Blikstein e José Paulo Paes. São Paulo: Cultrix, 2001.

JEANNERET-GRIS, Charles Edouard (pseud. Le Corbusier). Le Modulor: essai sur une mesure harmonique a l'echelle humaine applicable universellement a l'archicteture e a la mécanique, Vol. 1, collection Ascoral. Boulogne: Editions de L'Architecture D'Aujour'hui, 1950.

Le Modulor: la

parole est aux usagers, Vol. 2, collection Ascoral. Boulogne: Editions de L'Architecture D'Aujourd'hui, 1954.

JENCKS, Charles. The language of Post-Modern Architecture. Nova Iorque: Rizzoli, 1987.

Academy Editions, 1997.

The architecture of the jumping universe. Londres: 
Nonlinear architecture: new science = new architecture?, in Architectural Design, New science = new architecture?, volume 67, $\mathrm{n}^{\circ}$ 9/10, pp. 7-31. Londres: Academy Editions, 1997a.

Le Corbusier and the continual revolution in architecture. Nova Iorque: The Monacelli Press, 2000.

KERCKHOVE, Derrick de. A pele da cultura: uma investigação sobre a nova realidade eletrônica, tradução Luis Soares e Catarina Carvalho. Lisboa:

Relógio D'água, 1997.

Birkhauser, 2001.

The architecture of intelligence. Basiléia,

KNIGHT, Terry W. Languages of design: from known to new, Environmental and Planning B: Planning and Design, Vol. 8, pp. 213-238. London: Pion, 1981.

Color grammars: designing with lines and colors,

Environmental and Planning B: Planning and Design, Vol. 16, pp. 417-449. London: Pion, 1989.

Shape grammars and color grammars in design,

Environmental and Planning B: Planning and Design, Vol. 21, pp. 705-735. London: Pion, 1994.

KRUGER, Mario J. T. Teorias e analogias em arquitetura. São Paulo:

Projeto, 1986.

KUNH, Thomas S. A estrutura das revoluções científicas, tradução Beatriz Boeira e Nelson Boeira. São Paulo, Perspectiva, 2000.

LANCHA, Joubert. Palladio, Le Corbusier, Terragni, Tese de Doutorado apresentada a Faculdade de Arquitetura e Urbanismo da Universidade de São Paulo. São Paulo: FAU USP, 1999.

LE CORBUSIER. The chapel at Ronchamp. Londres: The Architectural Press, 1957.

Press, 1987. The decorative art of today. Londres: The Architectural Martins Fontes, 1992. Urbanismo, tradução Maria Ermantina Pereira. São Paulo, Paulo: Perspectiva, 2002.

LÉVI-STRAUSS, Claude. A estrutura e a forma, tradução Lucia Pessoa da Silveira, in PROPP, Vladimir, Morfologia do conto maravilhoso, pp. 181-205. Rio de Janeiro: Forense Universitária, 1984.

LÉVY, Pierre. As tecnologias da inteligência: o futuro do pensamento na era da informática, tradução Carlos Irineu da Costa. Rio de Janeiro: Editora 34, 1993.

34, 1996. O que é o virtual?, tradução Paulo Neves. São Paulo: Editora Editora 34, 1999. Cibercultura, tradução Carlos Irineu da Costa. São Paulo:

LIMA, Luiz Costa (Org.). O estruturalismo de Lévi-Strauss. Petrópolis: Vozes, 1968.

LINDSEY, Bruce. Digital Gehry: material resistance /digital construction. Basiléia: Birkhauser, 2001. 
LYNN, Greg. Architectural curvilinearity, in Architectural Design, Folding in architecture, volume 63, n 3/4, pp. 8-15. Londres: Academy Editions, 1993. 1998. Animate form. Nova Iorque: Princeton Architectural Press,

MACHADO, Arlindo. A ilusão especular. São Paulo: Brasiliense, 1984. Máquina e Imaginário: o desafio das poéticas

tecnológicas. São Paulo: EDUSP, 1993.

MACHADO, Irene. Escola de semiótica: a experiência de Tártu-Moscou para o estudo da cultura. São Paulo: Ateliê editorial, 2003. Impacto ou explosão? Cultura tecnológica e metáfora balística. Artigo apresentado na XXII INTERCOM, publicado em www.intercom.org.br/papers/xxii-ci/gt08/08m05.pdf, acessado em 24/08/2005.

MACHADO DE ASSIS, Joaquim Maria. Memórias póstumas de Brás Cubas. São Paulo: Ática, 1998.

MASSUMI, Brian. Sensing the virtual, building the insensible, in Architectural Design, Hypersurface architecture, volume 68, n 5/6, pp. 16-24. Londres: Academy Editions, 1998.

Strange horizon, in Architectural Design, Hypersurface architecture II, volume 69, n 9/10, pp. 12-19. Londres: Academy Editions, 1999.

McCULLOUGH, Malcom. Abstracting craft: the practiced digital hand. Cambridge: MIT Press, 1996.

MELVILLE, Herman. Bartleby, o escrivão, tradução Irene Hirsh. São Paulo: Cosac \& Naify, 2005.

MITCHELL, William J. The logic of architecture: design, computation and cognition. Cambridge: MIT Press, 1990.

The reconfigured eye: visual truth in the post-

photographic era. Cambridge: MITPress, 1992.

MONTANER, Josep Maria. Después del movimiento moderno: arquitectura de la segunda mitad del siglo XX. Barcelona: Gustavo Gili, 1993. A modernidade superada: arquitetura, arte e pensamento do século $X X$, tradução Esther Pereira da Silva e Carlos Gallego. Barcelona: Gustavo Gili, 2001.

MORIN, Edgar. O enigma do homem, tradução Fernando Ferro. Rio de Janeiro: Zahar, 1979. O método 3: o conhecimento do conhecimento, tradução Juremir da Silva. Porto Alegre: Sulina, 1999. O método 1: a natureza da natureza, tradução llana Heineberg. Porto Alegre: Sulina, 2002.

NASCIMENTO, Myrna de Arruda. Arquiteturas do pensamento, Tese de Doutorado apresentada a Faculdade de Arquitetura e Urbanismo da Universidade de São Paulo. São Paulo: FAU USP, 2002.

NOVAES, Adauto (Org.). O olhar. São Paulo: Cia das Letras, 1988.

NOVAK, Marcos. Liquid architectures in cyberspace, in BENEDIKT, Michael (ed.), Cyberspace: first steps, pp. 225-254. Cambridge: MITPress, 1991. 
Transmitting architecture, in Architectural Design,

Architects in cyberspace, volume 65, $\mathrm{n}^{\circ}$ 11/12, pp. 43-47. Londres: Academy Editions, 1995.

Next Babylon, soft Babylon, in Architectural Design, Architects in cyberspace II, volume 68, n 11/12, pp. 21-27. Londres:

Academy Editions, 1998.

PANOFSKY, Erwin. A perspectiva como forma simbólica. Lisboa: Edições 70, 1999.

PAPADAKIS, A., COOKE, C. and BENJAMIN, A. (Eds.). Deconstruction. Nova Iorque: Rizzoli, 1989.

PARENTE, André (Org.). Imagem-máquina: a era das tecnologias do virtual. Rio de Janeiro: Editora 34, 1993.

metafísica da exterioridade,

A última versão da realidade: o virtual como

http://www.eavparquelage.org.br/revista/andreparente.htm, acessado em 14/12/2002.

PEIRCE, Charles Sanders. Collected papers, [8 volumes]. Cambridge: Harvard University Press, 1978.

Semiótica, tradução José Teixeira Coelho Neto.

São Paulo: Perspectiva, 1995.

PEREZ-GOMEZ, Alberto. La genesis y superación del funcionalismo em arquitectura. México: Editorial Limusa, 1980.

Cambridge: MITPress, 1983.

Architecture and crisis of modern science.

PERRONE, Rafael. Desenho como signo da arquitetura, tese de Doutorado apresentada a Faculdade de Arquitetura e Urbanismo da Universidade de São Paulo. São Paulo, FAU USP, 1993.

PIAGET, Jean. O estruturalismo, tradução Moacyr de Amorim. São Paulo: Difel, 1974.

PIGNATARI. Décio. Semiótica e literatura. São Paulo: Perspectiva, 1974.

PLAZA, Julio. Tradução intersemiótica. São Paulo: Perspectiva, 1987. A imagem digital: crise dos sistemas de representação, tese de Livre docência apresentada ao Departamento de Artes Plásticas da Escola de Comunicações e Artes da Universidade de São Paulo. São Paulo: ECA USP, 1991.

PLAZA, Julio e TAVARES, Monica. Processos criativos com os meios eletrônicos: poéticas digitais. São Paulo: Hucitec, 1998.

PONGRATZ, Christian e PERBELLINI, Maria Rita. Natural Born caadesiners: Young american architects. Basiléia: Birkhauser, 2000.

PORTOGHESI, Paolo. Depois da arquitetura moderna, tradução Ana Luísa Nobre. São Paulo: Martins Fontes, 2002.

PRIGOGINE, Ilia. O fim das certezas: tempo, caos e leis da natureza, tradução Roberto Leal Ferreira. São Paulo: UNESP, 1996.

PRIGOGINE, Ilia e STENGERS, Isabelle. Entre o tempo e a eternidade, tradução Roberto Leal Ferreira. São Paulo: Companhia das Letras, 1992. 
PROPP, Vladimir. Morfologia do conto maravilhoso, tradução Jasna Sarhan. Rio de Janeiro: Forense Universitária, 1984a.

Estudo estrutural e histórico do conto de magia, tradução Lucia Pessoa da Silveira, in Morfologia do conto maravilhoso, pp. 207-225.

Rio de Janeiro: Forense Universitária, 1984b.

PUGLISI, Luigi Prestinenza. Hyper Architecture: Spaces in the Electronic Age. Basiléia: Birkhauser, 1999.

QUÉAU, Philippe. O tempo do virtual, tradução Henri Gervaiseau, in PARENTE, André, Imagem-Máquina, pp. 91-99. Rio de Janeiro: Editora 34, 1993.

RAJCHMAN, John. Existe uma inteligência do virtual?, tradução Maria Cristina Ferraz, in ALLIEZ, Éric (org.), Gilles Deleuze, uma vida filosófica, tradução Ana Lucia de Oliveira (coord.), pp. 397-413. São Paulo: Editora 34, 2000.

ROWE, Collin. Introduction in EISENMAN, Peter et al.. Five Architects. Nova Iorque: Oxford University Press, 1972.

Cambridge: MIT Press, 1976.

The mathematics of the ideal villa and other essays.

ROWE, Colin e SLUTZKY, Robert. Transparência literal e fenomenal, tradução Leila Vasconcellos, in Gávea, $n^{\circ} 2$, pp. 33-50. Rio de Janeiro: PUC RJ, 1985.

SAGGIO, Antonino. Flying carpets, in LINDSEY, Bruce, Digital Gehry: material resistance / digital construction, pp. 5-9. Basiléia: Birkhauser, 2001.

SANTAELLA, Lucia. Culturas e artes do pós-humano: da cultura das mídias à cibercultura. São Paulo: Paulus, 2003.

SANTOS, Laymert Garcia dos. Politizar as novas tecnologias: o impacto sócio-técnico da informação digital e genética. São Paulo: Editora 34, 2003.

SAUSSURE, Ferdinand de. Curso de Lingüística Geral, tradução Antonio Chelini, José Paulo Paes, Izidoro Blikstein. São Paulo: Cultrix, 1970.

SCULLY Jr., Vincent. Arquitetura moderna, tradução Ana Luiza Borges. São Paulo: Cosac \& Naify, 2002.

SIMON, Herbert. The architecture of complexity. Cambridge: MITPress, 1969.

SIMONDON, Gilbert. L'individu et sa genèse physico-biologique (líndividuation à la lumière des notions de forme et d'information). Paris: PUF, 1964.

Editions Montaigne, 1969.

Du mode d'existence des objets techniques. Aubier:

SOMOL, Robert .E. Dummy Text, or the diagrammatic basis of contemporary architecture, in EISENMAN, P. Diagram Diaries, pp. 7-25. Nova lorque: Universe, 1999.

SORKIN, Michael. Frozen light, in FRIEDMAN, Mildred Gehry talks: architecture + process, pp. 27-36. Nova Iorque: Universe, 1999.

STINY, George. Pictorial and formal aspects of shape and shape grammars. Basiléia: Birkhauser, 1975. 
Algorithmic aesthetics: computer models for criticism and design in the arts. Berkeley: University of California Press, 1978.

Introduction to shape and shape grammars, Environmental and Planning B: Planning and Design, Vol. 7, pp. 343-351. Londres: Pion, 1980.

SUMMERSON, John. The Classical Language of Architecture. Cambridge: MITPress, 1963.

TAFURI, Manfredo. "European Grafitti." Five $x$ Five = Twenty-five, in Oppositions $n^{\circ} 5$, pp. 35-74. Nova lorque: The Institute for the Architecture and Urban Studies, 1976.

La esfera y el laberinto: Vanguardias y arquitectura de Piranesi a los años 70. Barcelona: GGili, 1984.

TASSINARI, Alberto. O espaço moderno. São Paulo: Cosac \& Naify, 2001.

TEIXEIRA, Paulo Sergio. Espaço e arquitetura: entre o analógico e o digital, dissertação de Mestrado apresentada à Faculdade de Arquitetura e Urbanismo da Universidade de São Paulo. São Paulo: FAU USP, 2005.

TINIANOV, Youri. De la evolución literária, in Formalismo y Vanguardia textos de los formalistas rusos, vol. 1, Comunicación série B, pp. 116-139. Madrid: Alberto Corazon, 1973.

TURING, Alan. O jogo da imitação, tradução Issac Epstein, in Cibernética e comunicação, pp.45-82. São Paulo: Cultrix, 1973.

VALÉRY, Paul. Introdução ao método de Leonardo da Vinci, tradução Geraldo Gérson de Souza. São Paulo: Editora 34, 1998.

Variedades, tradução Maiza Martins Siqueira. São Paulo:

Iluminuras, 1999.

VENTURI, Robert. Complexidade e Contradição em Arquitetura, tradução Álvaro Cabral. São Paulo: Martins Fontes, 1995.

VENTURI, Robert., IZENOUR, Steven., SCOTT-BROWN, Denise.

Aprendiendo de Las Vegas: el simblismo olvidado de la forma arquitectónica. Barcelona: Editorial Gustavo Gili, 1978.

WIENER, Norbert. Cibernética, tradução Gita Ghinzberg. São Paulo:

Polígono/EDUSP, 1970.

Cibernética e Sociedade, tradução José Paulo Paes. São

Paulo: Cultrix, 2000.

WITTKOWER, Rudolph. La arquitetctura em la edad del humanismo. Buenos Aires: Nueva Visión, 1958.

ZAERA-POLO, Alejandro. Conversaciones con Frank O. Gehry, in El Croquis nº 74/75, pp. 6-36. Madrid: El Croquis Editorial, 1995a.

Tecnología informática en Frank O. Gehry \&

Associates, in El Croquis $n^{\circ} 74 / 75$, pp. 152-155. Madrid: El Croquis Editorial, 1995b.

Una conversación con Peter Eisenman, in El Croquis no 83, pp. 6-20. Madrid: El Croquis Editorial, 1997.

ZEVI, Bruno. Verso un'architettura organica: saggio sullo sviluppo del

pensiero architettonico negli ultimi cinquant'anni. Turin: Einaudi, 1945. 


\section{ARTIGOS ELETRÔNICOS}

MACHADO, IRENE. Impacto ou explosão? Cultura tecnológica e metáfora balística. Artigo apresentado na XXII INTERCOM, publicado em www.intercom.org.br/papers/xxii-ci/gt08/08m05.pdf, acessado em 24/08/2005.

\section{CATÁLOGOS e FOLHETOS}

Faculdade de Arquitetura e Urbanismo da Universidade de São Paulo, 1972. Sistemas que são sistemas de sistemas que são... tradução Marlene Picarelli do original da Revista Casabella 321, ano XXXI, 1967.

Instituto Tomie Othake. Gaudí: a procura da forma. São Paulo: Instituto Tomie Othake, 2004.

EMP (Experience Music Project) - The Building. Seattle: Marquand Books, 2000.

Walker Art Center (Minneapolis, EUA), The architecture of Frank Gehry. Nova lorque: Rizzoli, 1986.

\section{PERIÓDICOS}

AD - Architectural Design, volume 54, n 11/12, Londres, Academy Editions, 1984.

AD - Architectural Design, Folding in architecture, volume 63, $n^{\circ} 3 / 4$, Londres, Academy Editions, 1993.

AD - Architectural Design, Architects in cyberspace, volume 65, $n^{\circ}$ 11/12, Londres, Academy Editions, 1995.

AD - Architectural Design, Architecture after geometry, volume 67, n 5/6, Londres, Academy Editions, 1997.

AD - Architectural Design, New science $=$ new architecture?, volume 67, $\mathrm{n}^{\circ}$ 9/10, Londres, Academy Editions, 1997.

AD - Architectural Design, Hypersurface architecture, volume 68, no 5/6, Londres, Academy Editions, 1998.

AD - Architectural Design, Architects in cyberspace II, volume 68, $n^{\circ} 11 / 12$, Londres, Academy Editions, 1998.

AD - Architectural Design, Hypersurface architecture II, volume 69, $\mathrm{n}^{\circ}$ 9/10, Londres, Academy Editions, 1999.

$A D$ - Architectural Design, Contemporary processes in architecture, volume 70, $\mathrm{n}^{\circ}$ 3, Londres, Academy Editions, 2000.

A+U no 349, A+U Publishing Co., Tóquio, 1999.

A+U nº 368, A+U Publishing Co., Tóquio, 2001.

A+U nº 412, A+U Publishing Co., Tóquio, 2005.

Casabela, nº 344, Milão, Casabela, 1970.

El Croquis no 74/75, Frank Gehry 1991-1995, Madrid, El Croquis Editorial, 1995. 
El Croquis n 83, Peter Eisenman 1990-1997, Madrid, El Croquis Editorial, 1997.

Environmental and Planning B: Planning and Design, Vol. 7, Londres, Pion, 1980,

Environmental and Planning B: Planning and Design, Vol. 8, Londres, Pion, 1981.

Environmental and Planning B: Planning and Design, Vol. 16, Londres, Pion, 1989 ,

Environmental and Planning B: Planning and Design, Vol. 21, Londres, Pion, 1994.

Gávea, n² 2, Rio de Janeiro, PUC RJ, 1985,

JA (The Japan Architect) n 41, The Japan Architect Co., Tóquio, 2001.

JA (The Japan Architect) nº 47, The Japan Architect Co., Tóquio, 2002.

Óculum nº 3, Campinas, CAD/FAU PUCC, 1993.

Oppositions $\mathrm{n}^{\circ} 4$, Nova Iorque, The Institute for the Architecture and Urban Studies, 1974.

Oppositions $\mathrm{n}^{\circ}$ 5, Nova Iorque, The Institute for the Architecture and Urban Studies, 1976

Oppositions $n^{\circ} 6$, Nova Iorque, The Institute for the Architecture and Urban Studies, 1976

Oppositions n $\mathrm{n}^{\circ}$ 15/16, Nova lorque, The Institute for the Architecture and Urban Studies, 1979

Sinopses n 30, São Paulo, FAU USP, 1998. 
LISTA DE FIGURAS e CRÉDITOS DAS FIGURAS 
232 


\section{LISTA DE FIGURAS}

\section{Capítulo 1}

\section{Figura, título, página}

1. Edifício Seagram, Nova Iorque. Mies Van der Rohe, p. 30

2. Biblioteca em Exeter, EUA, Louis Kahn, p. 32

3. Baker House no MIT, Cambridge, EUA. Alvar Aalto, p. 32

4. Carpenter Center de Artes Visuais, Cambridge, EUA. Le Corbusier, p. 32

5. Modulor, p. 50

6. Unidade de habitação de Marselha, p. 61

7. aplicação do modulor ao projeto de Marselha: módulosmedida, p. 61

8. representação gráfica da aplicação do Modulor, p. 61

9. A lógica da construção em Marselha: módulos-objeto, p. 62 10. Museu Guggenheim, NY, Frank Lloyd Wright, p. 63

11. A tira espiralada da rampa, p. 64

12. Vista da rampa: de baixo para cima... , p. 64

13.... e de cima para baixo, p. 64

14. Ronchamp, p. 66

15. As comparações de Jencks, p. 66

16. UBU, p. 67

17. Planta de Ronchamp, p. 67

18. O modulor em Ronchamp, p. 67

19. Guild House, p. 68

20. Residência em Chestnut Hill, p. 68

21. Projeto para casa de praia, p. 68

22. A arquitetura comunicativa de Venturi, p. 69

\section{Capítulo 2}

Figura, título, página

23. Diagrama de forças de Alexander, p. 74

24. Lógica dos conjuntos, p. 75

25. Programa em diagrama, p. 75

26. Diagrama de sistemas e sub-sistemas, p. 75

27. Diagrama de sistemas e sub-sistemas, p. 75

28. Diagrama de sistemas e sub-sistemas, p. 75

29. Diagrama de sistemas e sub-sistemas, p. 75

30. Durand: combinações... , p. 77

31.... de elementos: , p. 77

32. funcionalização do projeto, p. 77

33. Ronchamp em obra, p. 93 
34. Niemeyer: catedral de Brasília, p. 93

35. Artigas, FAU USP, p. 93

36. Gaudí: sistema funicular, p. 94

37. Gaudí: Arcos funiculares para a igreja da Colônia Guell, p. 94

38. Gaudí: Arcos para o sotão da Casa Milà, p. 94

39. Gaudí: Nave da Sagrada Familia, p. 94

40. Gaudí: interior da igreja da Colônia Guell, p. 95

41. Gaudí: entrada da igreja, p. 95

42. Diagramas para construção de plantas, a partir de Durand, p. 97

43. Diagramas para construção de plantas, a partir de Durand, p. 97

44. Síntese de possíveis vilas Palladianas segundo a lógica da sintaxe, p. 97

45. Terry Knight: Shape Grammar: sistema notacional, p. 99

46. Knight: color grammar, p. 99

\section{Capítulo 4}

\section{1}

Figura, título, página

47. Casa Del Fascio: relação, p. 145

48. Vista da situação, p. 145

49. Terragni: interior, p. 145

50. Diagrama dos 9 quadrados segundo Hejduk, p. 146

51. Diagrama dos 9 quadrados segundo Hejduk, p. 146

52. Casa II de Eisenman e as margens da arquitetura: 'isto não é uma casa', p. 147

53. Hejduk: Texas House I, p. 148

54. Hejduk: Diamond Museum, p. 148

55. Casa I: diagramas, p. 149

56. Casa I: interior, p. 149

57. Casa II: diagramas, p. 149

58. Casa II: modelo 3D, p. 149

59. Casa III: diagramas, p. 149

60. Casa III: estrutura, p. 149

61. Casa IV: diagramas, p. 149

62. Casa IV: modelo de estudo, p. 149

63. Casa VI: decomposição, p. 150

64. Casa VI: diagramas, p. 151

65. Casa VI: diagramas, p. 151

66. Casa VI: diagramas, p. 151

67. Vista do interior com escadas, p. 151

68. Casa X: quadrantes, p. 152

69. Casa X: quadrantes, p. 152

70. Casa X: quadrantes, p. 152 
71. Casa X: sistemas, fragmentação, vazio, notações e "L"s.,p. 153

72. Casa $X:$ maquete de estudo, p. 153

73. Casa X: representação, p. 153

74. Casa X: representação, p. 153

75. Casa X: maquete, p. 154

76. Casa $X:$ ambigüidade, p. 155

77. Centro Aronoff: diagramas e transformações, p. 157

78. vista forntal

79. vista lateral, p. 158

80. vista posterior, p. 158

81. vista aérea, p. 158

82. interior, p. 158

83. interior, p. 158

84. Aronoff: maquete de implantação, p. 159

85. Catedral do ano 2000: maquetes, p. 159

86. Evolução do diagrama, p. 159

87. maquete: implantação, p. 160

88. maquete: implantação, p. 160

89. maquete e representações digitais do espaço interno, p. 160

90. planta e elevações, p. 160

91. maquete, p. 160

92. maquete, p. 160

93. Ito: diagramas conceituais e desenvolvimento do projeto, $p$. 161

94. diagrama de forças da cobertura, p. 162

95. detalhe, p. 162

96. detalhe, p. 162

97. vista, p. 162

98. vista, p. 162

99. plantas, p. 163

100. detalhe da estrutura, p. 163

101. vista interior, p. 163

102. vista interior, p. 163

103. maquete, p. 163

104. detalhes do interior, p. 163

\section{Capítulo 4}

4.2

Figura, título, página

105. Gehry: oficina de criação de mobiliário, p. 171

106. Exposição no Museu Guggenheim de Nova Iorque, $p$. 171

107. Garagem de Santa Mônica, p. 174

108. Vista frontal, p. 175

109. Tela de alambrado, p. 175 
110. Muro e janela da cozinha, p. 175

111. Interior, p. 175

112. Cozinha, p. 175

113. Interior, p. 176

114. Interior, p. 176

115. Axonométrica, p. 176

116. 'Vim para confundir', p. 178

117. Arquitetura pato: Las Vegas, p. 179

118. O binóculo da Chiat/Day em Venice, Califórnia, EUA, p. 179

119. Disney Concert Hall: maquetes de estudo, p. 180

120. Disney Hall: maquete em grande escala.

Experimentação, p. 180

121. Peixe de Barcelona, p. 181

122. estrutura, p. 181

123. maquete, p.181

124. O peixe no Catia, p. 182

125. vistas do peixe, p. 183

126. Disney Hall: croquis, p. 184

127. Casa Lewis: maquetes de estudo, p. 185

128. Bilbao: vista externa, p. 186

129. vista interna, p. 186

130. Interior: dobras, p. 186

131. croquis e wire-frame, p. 187

132. maquete de estudo, p. 187

133. construção digital de um volume, p. 187

134. Cortes digitais, p. 187

135. Wire frame, p. 187

136. maquetes, p. 187

137. maquetes, p. 187

138. maquetes, p. 187

139. [EMP] Experience Music Project, Seattle, Washington, EUA, p. 188

140. Purple Haze, p. 188

141. vista externa, p. 188

142. digitalização de maquete, p. 189

143. maquetes de estudo, p. 189

144. estrutura e superfície, p. 189

145. projeto da superfície, p. 189

146. estrutura, p. 189

147. análise Gaussiana, p. 189

148. vista externa, p. 189

149. vista externa, p. 189

150. vistas, p. 189

151. D-tower: vista diurna, p. 190

152. vistas noturnas, p. 190

153. vistas noturnas, p. 190

154. vistas noturnas, p. 190

155. gênese da forma e da estrutura, p. 190

156. vista interna da estrutura de baixo para cima, p. 190 
157. diagrama 3D: estrutura, p. 191

158. diagrama 3D: gênese, p. 191

159. dobras, p. 191

160. vista externa, p. 191

161. vista interna, p. 191

162. vista do fechamento, p. 191

\section{Capítulo 4}

\section{3}

\section{Figura, título, página}

163. Construção geométrica de uma linha, p. 198

164. Construção de uma spline, p. 198

165. Construção de uma superfície topológica: tira de Moebius, p. 199

166. Construção de um blob ， p. 199

167. estudos para seis casas embriológicas: o finito variável dos elementos, p. 202

168. estudos para seis casas embriológicas: o finito variável dos elementos, p. 202

169. estudos para seis casas embriológicas: o finito variável dos elementos, p. 202

170. estudos para seis casas embriológicas: o finito variável dos elementos, p. 202

171. estudos para seis casas embriológicas: o finito variável dos elementos, p. 202

172. vistas de um dos estudos, p. 202

173. estudos: seis casas, p. 203

174. maquete, p. 203

175. Data-driven, as linhas de conteúdo: estrutura, p. 204

176. detalhe dos nódulos, p. 204

177. linhas: vista interna, p. 204

178. vistas do espaço, p. 204

179. Paracube: vista geral, p. 205

180. detalhe interior, p. 205

181. vista do interior, p. 205

182. detalhe, p. 205

183. Paracube: detalhe, p. 206

184. Freshwater: interior, p. 206

185. desenho: estrutura e poço, p. 207

186. desenho: espaço interno, p. 207

187. vista externa: acesso, p. 207

188. vista externa, p. 207

189. modelo digital, interior: poço, p. 207

190. interior, p. 207

191. interior, p. 207

192. modelo digital, p. 208 
193. Casa virtual: modelo diagramático, p. 209

194. Corte, p. 209

195. Corte, p. 209

196. primeiro pavimento, p. 209

197. segundo pavimento, p. 209 


\section{CRÉDITOS DAS FIGURAS}

figura 1, 20 e 21: VENTURI, R. Complexidade e contradição, São Paulo: Martins Fontes, 1995, pp. 59, 178 e 154.

figura 2: BROWNLEE, David B.; LONG, David G. De. Louis I. Kahn: In the realm of architecture. New York: Rizzoli, 1991, p. 258.

figura 3: MONTANER, Josep Maria. Despues del movimiento moderno. Barcelona: Editorial Gustavo Gili, 1993, p.87.

figuras 4 e 6: MONTEYS, Xavier. Le Corbusier: Obras y proyectos. Barcelona: Editorial Gustavo Gili, 2005, pp. 226 e 149.

figuras 5, 7 e 8: JEANNERET-GRIS, Charles Edouard (pseud. Le Corbusier). 1950. Le Modulor: essai sur une mesure harmonique a l'echelle humaine applicable universellement a l'archicteture e a la mécanique, Vol. 1, Archicteure D'Aujour'hui, collection Ascoral, Boulogne, pp. 66, 145 e 143. figura 9: JEANNERET-GRIS, Charles Edouard (pseud. Le Corbusier). Unité d'habitacion a Marseille de Le Corbusier, L'Homme e l'archicteture, numero special 11-14, Paris, 1947.

figuras 10, 11, 12 e 13: LEVINE, Neil. The Architecture of Frank Lloyd Wright. Nova Iorque: Princeton University Press, 1996, pp. 363, 356, 359 e 358.

figuras 14, 17, 18 e 33: JEANNERET-GRIS, Charles Edouard. The Chapel at Ronchamp. Londres, Architectural Press, s/d.

figuras 15 e 16: JENCKS, Charles. Le Corbusier and the continual revolution in architecture. Nova lorque: The Monacelli Press, 2000, pp. 264 e 235.

figuras 19, 22 e 117: VENTURI, Robert., IZENOUR, Steven., SCOTT-BROWN, Denise. Aprendiendo de Las Vegas: el simblismo olvidado de la forma arquitectónica. Barcelona: Editorial Gustavo Gili, 1978, pp. 126 e 194, 116.

figuras 23 e 24 a 29: ALEXANDER, Christopher. Ensayo sobre la síntesis de la forma, tradução Enrique Revol. Buenos Aires: Ediciones Infinito, 1969, pp. 88 e 135 a 176.

figuras 30 a 32: DURAND, Jean-Nicolas-Louis. Précis of the lectures on architecture with Graphic portion of the lectures on architecture. Los Angeles: The Getty Research Center, 2000.

figura 34: NIEMEYER, Oscar. Oscar Niemeyer. London: Thames and Hudson, 1997.

figura 35: Artigas, J. B. Vilanova. Caderno de riscos originais:

prometo do edificio da FAU USP na cidade universitária. São Paulo: FAU USP, 1998.

figuras 36 a 41: Instituto Tomie Othake. Gaudí: a procura da forma. São Paulo: Instituto Tomie Othake, 2004.

figuras 42, 43 e 44: MITCHELL, William J. The logic of architecture: design, computation and cognition. Cambridge: MIT Press, 1990, pp. 148 e 173.

figura 45: KNIGHT, Terry W. Languages of design: from known to new, Environmental and Planning B: Planning and Design, Vol. 8, pp. 213238. London: Pion, 1981.

figura 46: KNIGHT, Terry W. Color grammars: designing with lines and colors, Environmental and Planning B: Planning and Design, Vol. 16, pp. 417-449. London: Pion, 1989.

figuras 47 e 49: FRAMPTON, Kenneth. GA Document: Special Issue 3 Modern Architecture 1920-1945. Tokyo: A.D.A. Edita Tokyo, 1983, pp. 384 e 385 .

figura 48: ZEVI, Bruno. Giuseppe Terragni. Barcelona: Editorial Gustavo Gili, 1981, p. 81. 
figuras 50, 51, 53 e 54: HEJDUK, John. The mask of Medusa, works 1947-1983. New York: Rizzoli, 1985, pp. 37 e 38.

figuras 52 e 55 a 67: EISENMAN, Peter. Diagram Diaries. New York: Universe Publishing, 1999, p. 49, 50, 62 a 66, 104, 105 e 218.

figuras 68 a 76: EISENMAN, Peter. House X. New York: Rizzoli, 1982.

figuras 77 a 92: El CROQUIS: Peter Eisenman. Madrid: El croquis editorial, n. 83, 1997, pp. 64 a 69, 49 e 152 a 161. 12 a 43.

figuras 93 a 98: JA. Toquio: The Japan Architect Co., n.47, 2002, pp.

figuras 99 a 104: AD. Londres: Wiley-academy, v.72, n.1, jan 2002, pp. 20 a 27.

figuras 105 a 107, 118 a 120, 126 a 132, 136 a 141, 148 a 150:

FRIEDMAN, Mildred. Gehry talks: architecture + process. Nova lorque:

Universe, 1999.

figuras 108 a 116: Walker Art Center (Minneapolis, EUA), The

architecture of Frank Gehry. Nova lorque: Rizzoli, 1986.

figuras 121 a 125, 133 a 135, 142 a 147: LINDSEY, Bruce. Digital

Gehry: material resistance /digital construction. Basiléia: Birkhauser, 2001. figuras 151 a 156 e 157 a 162: A+U. Toquio: A+U PublishingCo., v.01, n.412, 2005, pp. 84 a 87 e 76 a 83. figuras 163 a 166: LYNN, Grez. Animate form. Nova lorque:

Princeton Architectural Press, 1998, pp. 21, 22 e 31.

figuras 167 a 174: AD - Architectural Design, Contemporary

processes in architecture, volume $70, \mathrm{n}^{\circ} 3$, Londres, Academy Editions, 2000 , pp. 26 a 35.

figuras 175 a 183: AD - Architectural Design, Architects in

cyberspace II, volume 68, n 11/12, Londres, Academy Editions, 1998. figuras 184 a 192: AD - Architectural Design, Hypersurface architecture, volume 68, n 5/6, Londres, Academy Editions, 1998, pp. 48 a 55; A+U no 349, A+U Publishing Co., Tóquio, 1999, pp. 74 a 89. figuras 193 a 197: GALOFARO, Luca. Digital Eisenman: An Office of the Electronic Era. Basiléia, Birkhauser, 1999, pp. 65, 68 e 69. 